\begin{tabular}{|c|c|c|}
\hline $\begin{array}{l}J U L \\
\Delta t, 13\end{array}$ & 0 & Peot of $1 \frac{1}{622294}$ \\
\hline
\end{tabular}

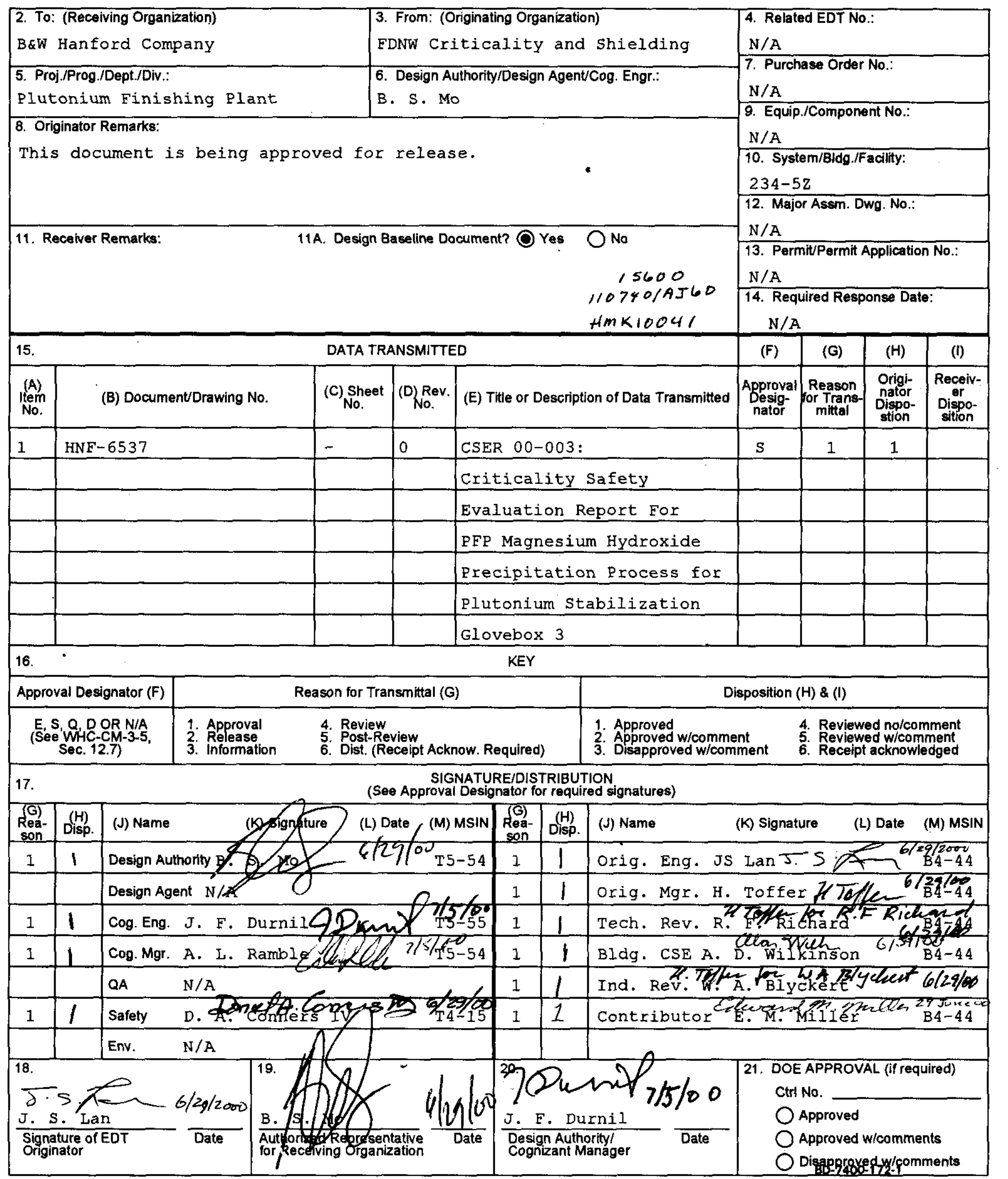

BD-7400-172-2 (10/97) 


\section{DISTRIBUTION SHEET}

To

Distribution

Project TitleMork Order

CSER 00-003: Criticality Safety Evaluation Report for PFP Magnesium Hydroxide Precipitation Process for Pu Stabilization Glovebox 3

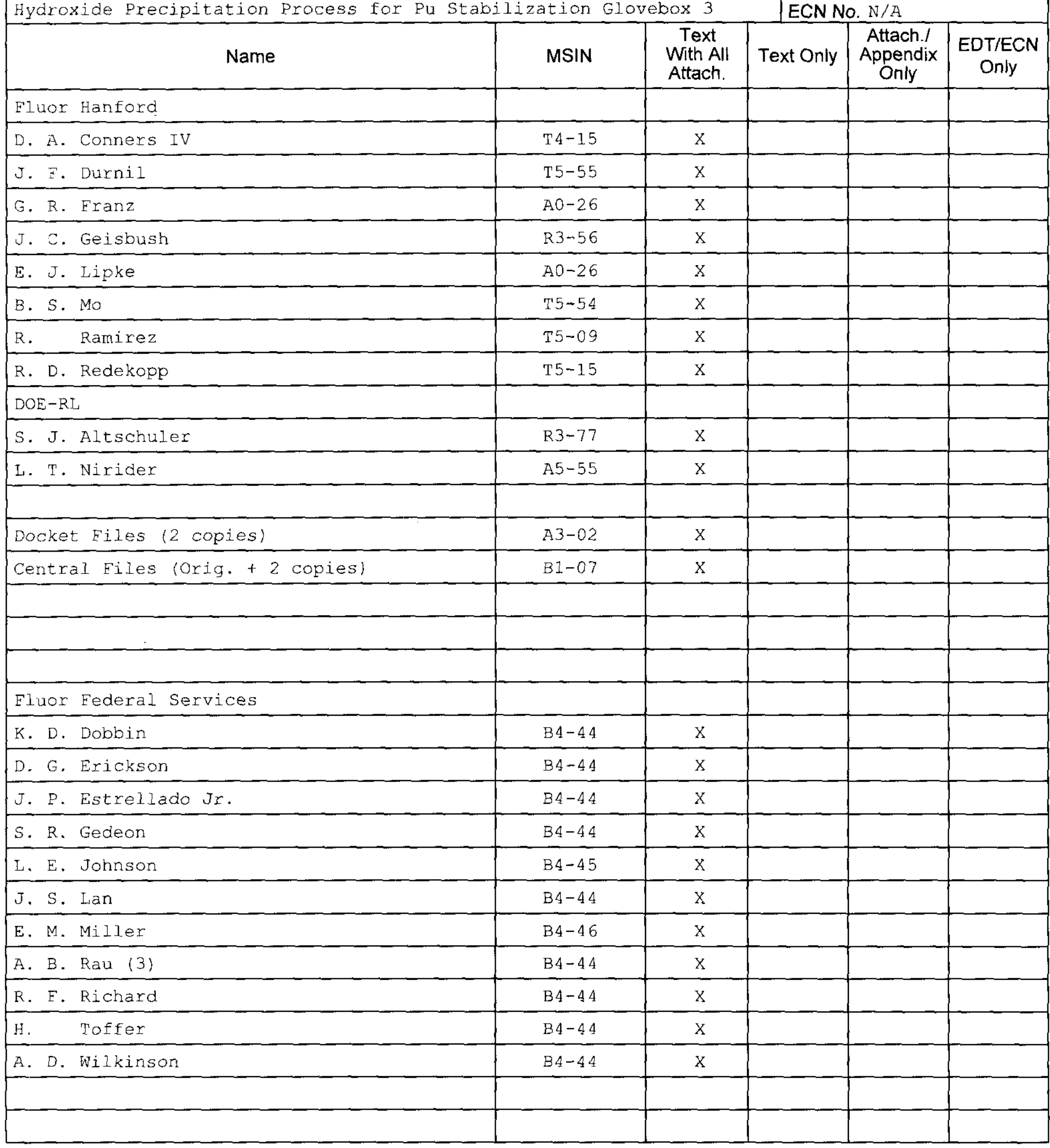

From

Criticality and Shielding FFS

Page 1 of 1

Date $6 / 27 / 00$

EDT No. 622294

ECN No. N/A

Attach

Appendix 


\section{CSER 00-003: Criticality Safety Evaluation Report for PFP Magnesium Hydroxide Precipitation Process for Plutonium Stabilization Glovebox 3}

Prepared for the U.S. Department of Energy

Assistant Secretary for Environmental Management

Project Hanford Management Contractor for the

U.S. Department of Energy under Contract DE-AC 06-96RL13200

Fluor Hanford

P.O. Box 1000

Richland, Washington 
HNF-6537

Revision 0

EDT 622294

\title{
CSER 00-003: Criticality Safety Evaluation Report for PFP Magnesium Hydroxide Precipitation Process for Plutonium Stabilization Glovebox 3
}

\author{
J. S. Lan \\ Fluor Federal Services \\ E. M. Miller \\ Fluor Federal Services
}

Date Published

May 2000

Prepared for the U.S. Department of Energy

Assistant Secretary for Environmental Management

Project Hanford Management Contractor for the

U.S. Department of Energy under Contract DE-ACO6-96RL13200

Fluor Hanford

P.O. Box 1000

Richland, Washington

$\frac{\text { Chis Itillenghan }}{\text { Release Approval }} \frac{7-12-00}{\text { Date }}$

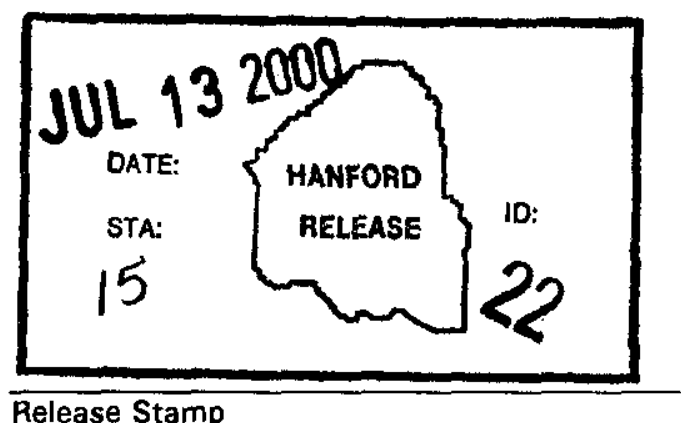


TRADEMARK DISCLAIMER

Reference herein to any specific commercial product, process,

or service by trade name, trademark, manufacturer, or

otherwise, does not necessarily constitute or imply its

endorsement, recommendation, or favoring by the United

States Government or any agency thereof or its contractors or subcontractors.

This report has been reproduced from the best available copy.

Printed in the United Stetes of America

Total Pages: 152 


\section{CSER 00-003: Criticality Safety Evaluation Report for PFP Magnesium Hydroxide Precipitation Process for Plutonium Stabilization Glovebox 3}

Key Words: Magnesium Hydroxide, Precipitation Process, Glovebox 3, PFP, Criticality Safety, Fissile Material, Precipitators, $\mathrm{Mg}(\mathrm{OH})_{2}$, Filter Basin, Hot Plate, Flocculent, Vacuum system

Abstract: This Criticality Safety Evaluation Report analyzes the stabilization of plutonium/uranium solutions in Glovebox 3 using the magnesium hydroxide precipitation process at PFP. The process covered are the receipt of diluted plutonium solutions into three precipitation tanks, the precipitation of plutonium from the solution, the filtering of the plutonium precipitate from the solution, the scraping of the precipitate from the filter into boats, and the initial drying of the precipitated slurry on a hot plate. A batch (up to $2.5 \mathrm{~kg}$ ) is brought into the glovebox as plutonium nitrate, processed, and is then removed in boats for further processing. This CSER establishes limits for the magnesium hydroxide precipitation process in Glovebox 3 to maintain criticality safety while handling fissionable material. 


\section{CSER 00-003: \\ Criticality Safety Evaluation Report for PFP \\ Magnesium Hydroxide Precipitation Process for \\ Plutonium Stabilization \\ Glovebox 3}

JUNE 29, 2000

Prepared by

Fluor Federal Services, Inc.

Richland, Washington

For

Fluor Hanford, Inc.

In support of

Contract No. 65100241

Task No. 5204-12

Prepared by: 2. S. Date: $6 / 29 / 2000$ J. S. Lan, Criticality and Shielding

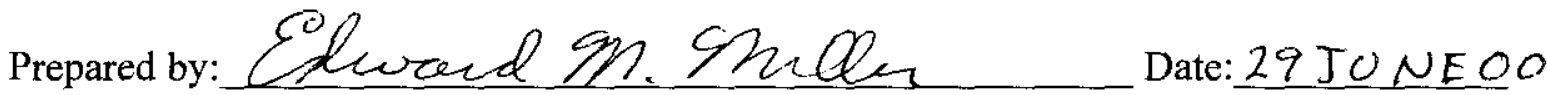

E. M. Miller, Criticality and Shielding

Reviewed by: Hew Toffer for R.F Richared Date: 6129/00

R. F. Richard, Criticality and Shielding

Approved by:_ Hom To/fer

Date: $6 / 29 / 00$

H. Toffer, Manager, Criticality and Shielding

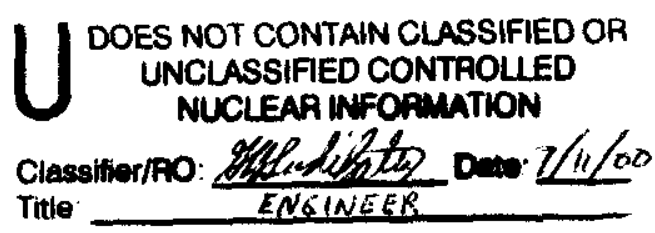


HNF-6537 REV. 0

This page intentionally left blank 


\section{TABLE OF CONTENTS}

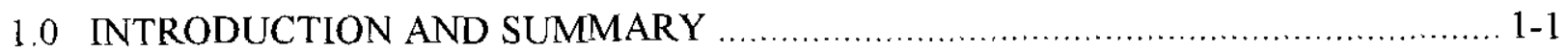

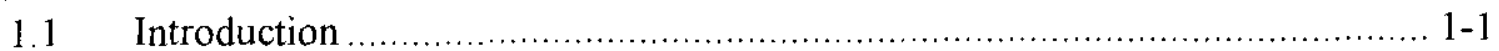

1.2 Double Contingency Documentation..................................................... 1-2

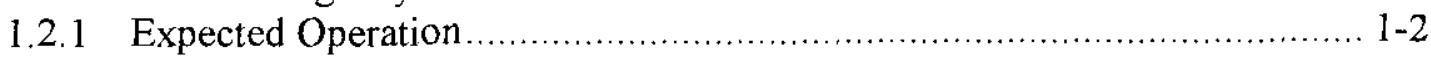

1.2.2 Conservative Normal Operating Conditions …….................................. 1-3

1.2.2 Base Case Conditions .................................................................. 1-4

1.2.3 Contingency Conditions ………….................................................. 1-5

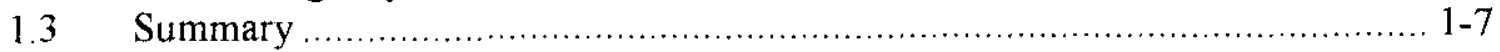

2.0 SYSTEM DESCRIPTION AND NORMAL OPERATION ……..............................

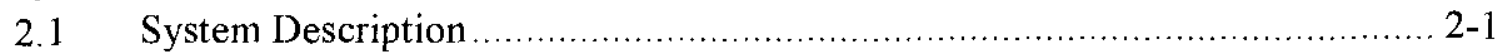

$2.2 \quad$ Facility and Equipment Description ....................................................... 2-2

2.3 Fissionable Materials Description ……............................................... 2-4

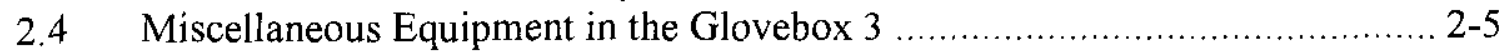

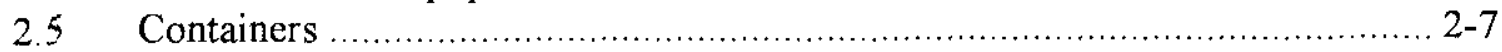

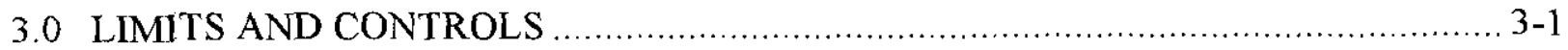

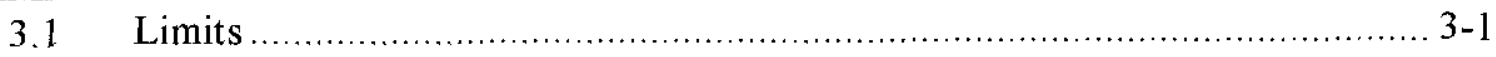

3.2 Process Controls ............................................................................. 3-1

3.3 Engineered Safety Features ………................................................... 3-2

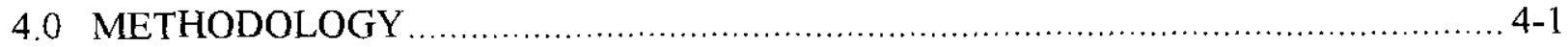

4.1 MCNP4B Verification \& Validation .................................................... 4-1

4.2 Sub-Critical Limit ............................................................................ 4-1

4.3 Application of Double Contingency Principle .............................................. 4-1

4.4 Hazards Assessment ……................................................................. 4-2

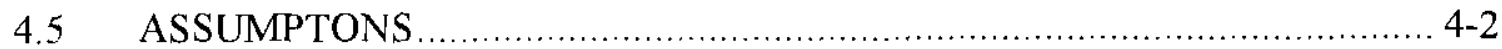

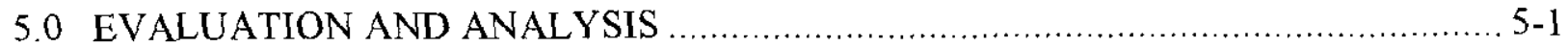

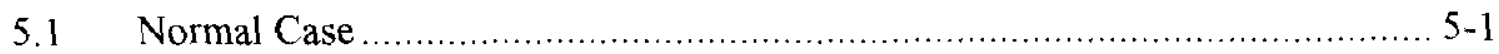

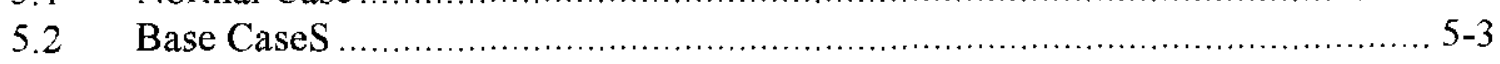

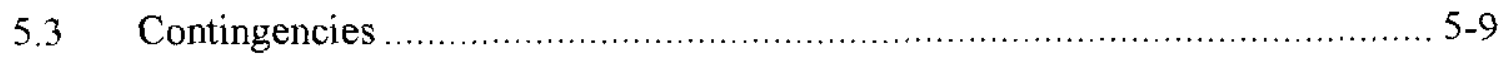

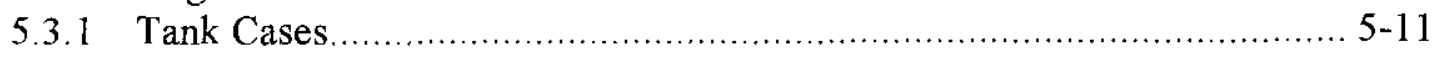

5.3.2 Over Batched Boat ............................................................... 5-12

5.3.3 Loss of Spacing Between Boats.................................................... 5-12

5.3.4 Aggregate of Unspaced Containers ……......................................... 5-13

5.3.5 Seismic with Intact Tanks .......................................................... 5-15

5.3.6 Seismic and Fire Cases with Broken Tanks ........................................ 5-16

5.3.7 Plutonium Container Against the Glovebox........................................ 5-17

5.3.8 Double Batched Vacuum Filter Basin ................................................ 5-18

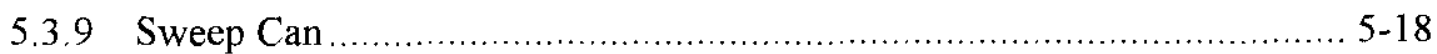

5.3.10 High Enriched Uranium ........................................................... 5-19

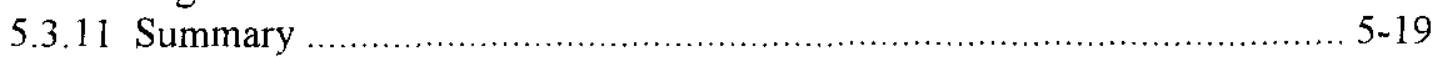

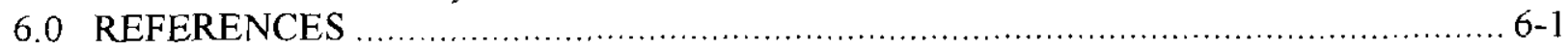

APPENDIX A - INDEPENDENT REVIEW COMMENTS AND CHECKLIST …............. A-1

APPENDIX B - MCNP4B COMPUTER CODE VALIDATION …….............................

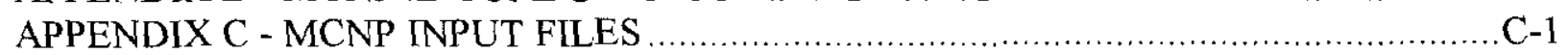


APPENDIX D - PRELIMINARY HAZARD ANALYSIS ….................................. D-1

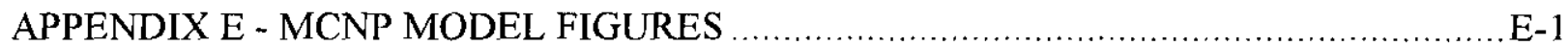

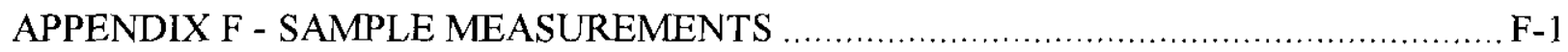

APPENDIX G - COMPONENT SENSITIVITY CALCULATIONS …........................ G-1

APPENDIX H - BASIS DOCUMENT ............................................................

\section{List of Tables}

Table 1-1. Summary of Base Case Limits....................................................... 1-4

Table 1-2. Glovebox 3 Contingency Summary ............................................. 1-5

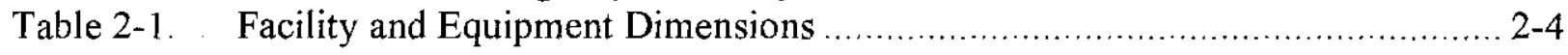

Table 2-2. Fissionable \& Moderator Material Contents for Normal Operation Condition... 2-5

Table 5-1-1. Modeled Facility and Equipment Dimensions for All Conditions ................... 5-1

Table 5-1-2. Mixture Density and Material Weight Fraction for Normal Operation

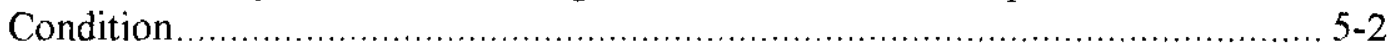

Table 5-1-3. Reflector Material Contents for Normal Operation Condition........................ 5-3

Table 5-2-1. Fissionable \& Moderator Material Contents for Base Case .......................... 5-6

Table 5-2-2. Mixture Density and Material Weight Fraction for Base Case ....................... 5-7

Table 5-2-3. Reflector Material Contents for Base Case ............................................ 5-7

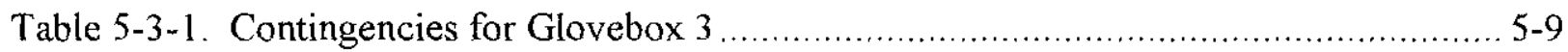

Table 5-3-2. Plutonium/Water Mixture Parameters for Density Range of 0.2 to $5.5 \mathrm{~g} \mathrm{Pu} / \mathrm{cm}^{3}$ in a Furnace Boat .................................................... 5-16

Table 5-3-3. Calculational Results for Plutonium/Water Mixtures in a Furnace Boat......... 5-16

\section{List of Figures}

Figure 2-1. Magnesium Hydroxide Process Schematic Drawing $\ldots \ldots \ldots \ldots \ldots \ldots \ldots \ldots \ldots \ldots \ldots \ldots$

Figure 5.3.1 Interspersed Moderation Contingency ............................................... 5-17 


\subsection{INTRODUCTION AND SUMMARY}

\subsection{INTRODUCTION}

The Magnesium Hydroxide Process is one of the Plutonium Stabilization tasks at the Plutonium Finishing Plant (PFP). This process stabilizes plutonium that is stored as a solution by converting it to an oxide.

The plutonium bearing solution consists primarily of plutonium nitrate, $\mathrm{Pu}\left(\mathrm{NO}_{3}\right)_{4}$, in an aqueous nitric acid, $\mathrm{HNO}_{3}$, solution. Solutions greater than $450 \mathrm{~g} \mathrm{Pu} / \mathrm{L}$ are not expected because both PUREX and PFP have always had a limit of $450 \mathrm{~g} \mathrm{Pu} / \mathrm{L}$ on plutonium nitrate solutions. Two independent determinations of the feed fissionable concentration are made before the batch is pumped to Glovebox 3. The container label listing of fissionable material and lab analysis of a sample are two methods usually used to make the determination of the feed fissionable material concentration. The primary product of the precipitation process is plutonium hydroxide, $\mathrm{Pu}(\mathrm{OH})_{4}$. The precipitate filtered out of the filtrate is called filter cake and contains approximately $50 \mathrm{wt} \%$ water. Moisture may be driven off the $\mathrm{Pu}(\mathrm{OH})_{4}$ precipitate by heating on a hot plate. This and further heating converts the hydroxide to an oxide suitable for storage. The plutonium oxide in the resultant solids would have a density of less than $1 \mathrm{~g} \mathrm{Pu} / \mathrm{cm}^{3}$. The filtrate will normally have a plutonium concentration less than the concentration limit for the ultimate disposal system. Material that is above the disposal limit will be recycled through the precipitation process until it meets the disposal limit.

The process carried out in Glovebox 3 is the receipt of diluted plutonium solutions into the three precipitation tanks, the precipitation of plutonium from the solution, the filtering of the plutonium precipitate from the solution, the scraping of the precipitate from the filter into boats, and the initial drying of the precipitated slurry in a boat on a hot plate. Material accountability may require that this process be completed and the glovebox emptied of all the plutonium brought in as a batch that filled the three precipitation tanks before another batch may fill the tanks. However, this criticality analysis would allow operations to process up to six batches simultaneously in Glovebox 3. A batch is allowed to have up to $2.5 \mathrm{~kg}$ of plutonium. A batch is brought into the glovebox as plutonium nitrate and is removed in boats for stabilization. The boat dock can store up to two boats. If the filtrate that is sent to Glovebox 4 needs to be brought back to Glovebox 3 for further processing, the filtrate would be treated as a separate batch. The filtrate cycled through Glovebox 3 to take a sample to determine the plutonium concentration in the filtrate need not be considered a batch.

Operations makes two independent determinations of the plutonium concentration in batch of nitrate feed solution coming into Glovebox 3. First, information contained on the label on the storage container is used to make up a blend plan that sets the solution concentration to be sent to Glovebox 3. Lab analysis results of a sample taken from the blended solution in the blend tanks prior to pumping the solution to Glovebox 3 is the second determination of the plutonium concentration of the blended solution in the blend tanks. A second independent sample of the blended feed solution may be used as the second determination of the fissionable material concentration. 
This CSER shows that the magnesium hydroxide process to be run in Glovebox 3 is acceptable when controlled to the limits listed in Section 3.0. No single credible event has a $k_{\text {eff }}$ containing the computer code bias and calculational uncertainty that exceeds the criticality safety limit of 0.95 .

\subsection{DOUBLE CONTINGENCY DOCUMENTATION}

This section presents a summary of the expected operations, the expected normal conditions, and the base case for normal conditions plus anticipated off-normal conditions for the precipitation glovebox. A hazards assessment described in Section 4.4 is used to systematically identify off-normal events and classify them as likely or unlikely events. The likely events become part of the base case while unlikely events are analyzed as contingencies. Table 1-1 lists the criticality limits and base case conditions for each criticality parameter. Table 1-2 summarizes the bounding contingency events.

\subsubsection{Expected Operation}

The process design would have operators pump approximately $12 \mathrm{~L}$ of up to $50 \mathrm{~g} \mathrm{Pu} / \mathrm{L}$ of plutonium nitrate in a nitric acid solution into each of three $20 \mathrm{~L}$ capacity 6 -in. diameter precipitation tanks. The concentration and volume of the feed solution are selected to fill the three precipitation tanks in Glovebox 3 up to a total design loading of $1.8 \mathrm{~kg}$ of plutonium. The three precipitation tanks are allowed to contain up to a total of $2.5 \mathrm{~kg}$ of plutonium in a plutonium nitrate solution. This mass limit allows operational flexibility in the concentration/volume combinations used. The $2.5 \mathrm{~kg}$ plutonium limit for the precipitation tanks sets a mass limit for the basin and boats that are allowed only one batch of precipitate from the precipitation tanks.

Magnesium hydroxide is added to neutralize the solution and precipitate the plutonium as $\mathrm{Pu}(\mathrm{OH})_{4}$. Operators use a vacuum sparge to agitate the tank contents to facilitate the precipitation of the fissionable material. The addition of a few milliliters of organic polymer flocculent speeds the settling of precipitate out of the solution by acting as attachment centers for plutonium precipitate. The precipitate and solution are gravity drained through flexible plastic tubing to a 17 -in. diameter filter on the vacuum filter basin. Filtrate is removed by drawing a vacuum on the outlet side of the filter. The filtrate is collected in a phase separator tank, then pumped through a polishing filter and out of the glovebox to Glovebox 4 for disposal.

Operators scrape plutonium precipitation cake with approximately $50 \mathrm{wt} \%$ water from the filter into a 5 -in. by 11 -in. by 2.5 -in. deep furnace boat that has a $2.25 \mathrm{~L}$ volume. A hot plate reduces the water content of the plutonium. The boat is passed thru Glovebox 5 to conveyor HC3 that moves the boat to a muffle furnace in another glovebox for further high temperature processing. 


\subsubsection{Conservative Normal Operating Conditions}

Plutonium nitrate solutions stored at the PFP are allowed to have concentrations as high as $450 \mathrm{~g} \mathrm{Pu} / \mathrm{L}$. These solutions are blended with nitric acid to reduce the concentration to approximately $50 \mathrm{~g} \mathrm{Pu} / \mathrm{L}$ before pumping the solution to the precipitator tanks in Glovebox 3. The maximum feed concentration is arbitrarily set at $100 \mathrm{~g} \mathrm{Pu} / \mathrm{L}$, twice the process design value, to set a base case limit. At $100 \mathrm{~g} \mathrm{Pu} / \mathrm{L}$ concentration, the $2.5 \mathrm{~kg}$ limit on plutonium mass in the precipitation tanks limits the total solution volume to $25 \mathrm{~L}$. The feed solution is pumped into the precipitation tanks through several control valves and the piping at the bottom of the tanks. Interlocked valves control filling the tanks and all other fluid movements in Glovebox 3. However, the criticality analysis does not utilize the valve interlocks. The upset conditions have the tanks filled with the most reactive concentration of plutonium nitrate solution.

The plutonium nitrate is precipitated from the nitric acid solution by the addition of magnesium hydroxide to neutralize the nitric acid. The operators assure that all the plutonium precipitates by adding $5 \mathrm{wt} \%$ excess magnesium hydroxide and agitating the tank contents. They also add flocculent to speed settling. A filter removes the precipitated plutonium hydroxide $\left[\mathrm{Pu}(\mathrm{OH})_{4}\right]$ from the filtrate by pulling a vacuum below the filter. The filter cake is usually about $50 \mathrm{wt} \%$ water, but can be higher. Boats are modeled filled with plutonium oxide mixed with water. Operators scrape the filter cake, typically containing $1.8 \mathrm{~kg}$ of plutonium from the filter into a furnace boat or boats. The upper limit on a precipitation batch is established by limiting the total plutonium mass in the feed solution to the three precipitation tanks to $2.5 \mathrm{~kg}$ of plutonium. This limit is not necessary for the precipitation tanks, which can safely contain $18 \mathrm{~kg}$ each. This limit sets a maximum to the amount of plutonium in a batch in the remaining processes in the glovebox to $2.5 \mathrm{~kg}$. This limit is made because precipitation divides the plutonium in the feed solution between the precipitation cake and filtrate by a ratio not determined until the precipitation cake and filtrate leave the glovebox. The masses in the filter basin and boats in Glovebox 3 depend on determination of the concentration and volume of the feed solution pumped to the three precipitation tanks.

A boat is heated on top of a hot plate to reduce the water content in the filter cake. A 1 in. square bar separates two boats in the boat storage area. Boats are passed through a dog leg pass through, Glovebox 5, to a conveyor to move them to other gloveboxes for further processing.

The effect of operators' hands, rags, piping, plastic tubing, and equipment is modeled as one inch of water reflector around parts of the tanks, filters, and boats. Operators' bodies are modeled as twelve inches of water reflector around the sides of the glovebox. Even though it is difficult for operators to get under the glovebox or to store fissionable or reflective material under the glovebox, full water reflection of six inches (page 1I.E-2 of ARH-600 [Carter 1968]) is modeled directly below the glovebox floor. An eighth inch layer of $3 \mathrm{~g} \mathrm{Pu} / \mathrm{cm}^{3}$ on the glovebox floor and conservative diameter of the precipitation tanks accounts for the sweeps can, leak detection bottle, sample bottles, and trash bags in the glovebox. The water under the glovebox is conservative because bracing on the lower sides of the glovebox make storage or operator access under the glovebox difficult. One inch of water above the glovebox models the reflection of the ceiling, which is more than three feet above the top of the glovebox, and water lines, electrical 
conduit, vacuum piping, and other plant equipment. Additional modeling parameters for normal conditions are presented in Section 5.1.

\subsubsection{Base Case Conditions}

The base case encompasses the normal conditions, described above, along with anticipated upset events. Table 1-1 summarizes the limits for normal conditions and lists the abnormal but anticipated conditions for each criticality parameter. The combination of normal conditions allowed by limits and anticipated abnormal conditions are used to evaluate the criticality safety of normal operations in Glovebox 3 as the base case. Each contingency is analyzed by adding it to the base case. Section 5.2 of this CSER presents analyses of the base case conditions. The $k_{\text {eff }}$ for the base case described in this section and in Section 5.2 is 0.882 .

Table 1-1. Summary of Base Case Limits

\begin{tabular}{|c|c|c|}
\hline $\begin{array}{l}\text { Controlled } \\
\text { Parameter }\end{array}$ & Limit & $\begin{array}{l}\text { Abnormal but anticipated } \\
\text { Conditions }\end{array}$ \\
\hline Mass & $\begin{array}{l}\leq 2.5 \mathrm{~kg} \mathrm{Pu} \text { per boat; } \\
\text { Maximum of four boats in Glovebox } 3 \text {; } \\
\text { Maximum of one boat in Glovebox } 5 \text {. } \\
\leq 2.5 \mathrm{~kg} \mathrm{Pu} \text { in vacuum filter basin; } \\
\leq 2.5 \mathrm{~kg} \text { total Pu in precipitation tanks; }\end{array}$ & $\begin{array}{l}2.75 \mathrm{~kg} \text { Pu per total in } \\
\text { precipitation tanks, in the } \\
\text { basin, and in a boat; } \\
\text { Precipitation tank full }(20 \mathrm{~L}) \\
\text { of } 450 \mathrm{~g} \mathrm{Pu} / \mathrm{L}(9 \mathrm{~kg}) \\
\text { precipitated to } 6 \mathrm{in} \text {. of } 3 \mathrm{~g} \\
\text { Pu/ } \mathrm{cm}^{3} \text { in the bottom of each } \\
\text { precipitator tank }\end{array}$ \\
\hline Volume & $\begin{array}{l}\leq 2.3 \mathrm{~L} / \text { boat, up to } 4 \text { boats inside } \\
\text { Glovebox } 3,1 \text { boat in the Glovebox } 5 \text {. } \\
\leq 20 \mathrm{~L} / \text { precipitation tank; } \\
\leq 20 \mathrm{~L} / \text { phase separator tank; } \\
\leq 11.1 \mathrm{~L} \text { vacuum trap tank; } \\
\leq 5.5 \mathrm{~L} \mathrm{vacuum} \mathrm{catch} \mathrm{tank;} \\
\text { nominal } 1 / 2 \mathrm{~L} \text { sweeps can; } \\
\text { one } \mathrm{L} \text { bottle for leak detection; } \\
\text { three nominal } 250 \mathrm{~mL} \text { sample bottles; } \\
\text { Twelve } 50 \mathrm{~mL} \text { sample bottles. }\end{array}$ & None \\
\hline Moderation & Fire Fighting Category $\mathrm{C}$. & None \\
\hline Interaction & $\begin{array}{l}\text { Four (4) boats are allowed in Glovebox } 3 \text { : } \\
\text { two boats in the boat dock and one boat } \\
\text { each at the hot plate and at the vacuum } \\
\text { filter basin; one boat may be anywhere } \\
\text { except within } 25.4 \mathrm{~cm} \text { ( } 10 \text { in.) of the glass } \\
\text { tanks in Glovebox } 3 . \\
\text { Remove all fissionable material except } \\
\text { holdup prior to changing HEPA filter. }\end{array}$ & $\begin{array}{l}\text { A boat under precipitation } \\
\text { tanks with } 2.75 \mathrm{~kg} \mathrm{Pu} \text {. }\end{array}$ \\
\hline Reflection & $\begin{array}{l}\text { Criticality drain visibly unobstructed. } \\
\text { No close fitting material around tanks. }\end{array}$ & None \\
\hline
\end{tabular}


HNF-6537 REV. 0

\begin{tabular}{|c|c|c|}
\hline $\begin{array}{l}\text { Controlled } \\
\text { Parameter }\end{array}$ & Limit & $\begin{array}{l}\text { Abnormal but anticipated } \\
\text { Conditions }\end{array}$ \\
\hline Geometry & $\begin{array}{l}\text { Maximum of } 6.2 \text { in. inside diameter of } \\
\text { tanks, pump, surge tank, and piping. } \\
\text { Three precipitation tanks maintained in a } \\
\text { line. } \\
\text { Filter basin is limited to nominal } 17 \text { in. } \\
\text { diameter, maximum of } 2.1 \text { in. depth above } \\
\text { and } 1 \text { in. depth below the perforated filter } \\
\text { plate. } \\
\text { Boats limited to nominal } 2.5 \text { in. depth. } \\
\text { Filter drip pan is limited to nominal } 2 \text { in. } \\
\text { depth. }\end{array}$ & $\begin{array}{l}\text { Tanks modeled at } 6.3 \text { in. } \\
\text { inside diameter; } \\
\text { Filter left out of the vacuum } \\
\text { filter basin. }\end{array}$ \\
\hline Isotopics & None & None \\
\hline Enrichment & $\leq 50 \%$ U -235 in $\mathrm{U}$. & None \\
\hline Density & $\mathrm{Pu}$ or U metal prohibited in Glovebox 3. & None \\
\hline Concentration & Feed solution $\leq 100 \mathrm{~g} \mathrm{Pu} / \mathrm{L}$ & $450 \mathrm{~g} \mathrm{Pu} / \mathrm{L}$ feed solution. ${ }^{*}$ \\
\hline Poisons & None. & None \\
\hline
\end{tabular}

* Section 5.2 shows that $250 \mathrm{~g} \mathrm{Pu} / \mathrm{L}$ is the most reactive plutonium nitrate solution over the range of 0 to $450 \mathrm{~g} \mathrm{Pu} / \mathrm{L}$.

\subsubsection{Contingency Conditions}

Table 1-2 summarizes the analyses of the unlikely, independent, non-concurrent off-normal events (contingencies). Each event is assumed to occur with the glovebox configured as the base case with the contingency condition added. This list provides a conservative envelope of the off-normal events. This table summarizes the results of the contingency evaluations documented in Section 5.3 of this CSER.

Table 1-2. Glovebox 3 Contingency Summary

\begin{tabular}{|l|l|l|l|}
\hline $\begin{array}{l}\text { Contingency } \\
\text { Description }\end{array}$ & $\begin{array}{l}\text { Affected } \\
\text { Criticality } \\
\text { Parameter(s) }\end{array}$ & $\begin{array}{l}\text { Barriers that make } \\
\text { contingency unlikely }\end{array}$ & $\begin{array}{l}\text { keff } \\
\text { bounding } \\
\text { contingency } \\
\text { (case ID) }\end{array}$ \\
\hline $\begin{array}{l}\text { Seismic event with } \\
\text { glass tanks breaking } \\
\text { and sprinkler water } \\
\text { added }\end{array}$ & $\begin{array}{l}\text { Reflection } \\
\text { Moderation }\end{array}$ & $\begin{array}{l}\text { Seismic event unlikely; } \\
\text { requires severe damage from } \\
\text { seismic and concurrent } \\
\text { sprinkler water inflow into } \\
\text { the damaged glovebox. } \\
\text { Criticality drain limits depth } \\
\text { of water on glovebox floor. } \\
\text { Limited volume water } \\
\text { supply. }\end{array}$ & $\begin{array}{c}\sigma=0.0005 \\
(\mathrm{cc5} 5)\end{array}$ \\
\hline
\end{tabular}




\begin{tabular}{|c|c|c|c|}
\hline $\begin{array}{l}\text { Contingency } \\
\text { Description }\end{array}$ & $\begin{array}{l}\text { Affected } \\
\text { Criticality } \\
\text { Parameter(s) }\end{array}$ & $\begin{array}{l}\text { Barriers that make } \\
\text { contingency unlikely }\end{array}$ & $\begin{array}{l}\mathbf{k}_{\text {eff }} \\
\text { bounding } \\
\text { contingency } \\
\text { (case ID) }\end{array}$ \\
\hline $\begin{array}{l}20 \mathrm{~L} \text { of } 450 \mathrm{~g} \mathrm{Pu} / \mathrm{L}(9 \\
\mathrm{kg} \text { ) in each of } 3 \\
\text { precipitation tanks } \\
\text { precipitated to } 15.2 \mathrm{~cm} \\
\left(6 \mathrm{in} \text {.) of } 3 \mathrm{~g} \mathrm{Pu} / \mathrm{cm}^{3} \text { in }\right. \\
\text { the bottom of the three } \\
\text { tanks with the } \\
\text { remainder of the tank } \\
\text { filled with } 250 \mathrm{~g} \mathrm{Pu} / \mathrm{L}\end{array}$ & $\begin{array}{l}\text { Mass } \\
\text { Concentration }\end{array}$ & $\begin{array}{l}\text { Operations makes two } \\
\text { independent determinations } \\
\text { of the fissionable material } \\
\text { concentration in each batch. } \\
\text { Tank diameter protected by } \\
\text { configuration management. } \\
\text { Operator training/procedure }\end{array}$ & $\begin{aligned} & \mathrm{k}_{\mathrm{eff}}=0.8884 \\
& \sigma=0.0005 \\
&(\mathrm{ccl})\end{aligned}$ \\
\hline $\begin{array}{l}\text { Precipitation tanks, } \\
\text { vacuum tanks, phase } \\
\text { separation tank filled } \\
\text { with } 250 \mathrm{~g} \mathrm{Pu} / 1 \\
\text { plutonium nitrate } \\
\text { solution with } 15.2 \mathrm{~cm} \\
(6 \mathrm{in} .) \text { of } 3 \mathrm{~g} \mathrm{Pu} / \mathrm{cm}^{3} \text { of } \\
\mathrm{PuO}_{2} \text { solids in the } \\
\text { bottom of the three } \\
\text { precipitation tanks }\end{array}$ & $\begin{array}{l}\text { Mass } \\
\text { Interaction }\end{array}$ & $\begin{array}{l}\text { Operator training/procedure, } \\
\text { Equipment or processing } \\
\text { failure allowing concentrated } \\
\text { solution into all the tanks. } \\
\text { Tank diameter protected by } \\
\text { configuration management. }\end{array}$ & $\begin{aligned} & \mathrm{k}_{\mathrm{eff}}=0.8932 \\
& \sigma=0.0005 \\
&(\mathrm{cc} 2 \mathrm{c})\end{aligned}$ \\
\hline $\begin{array}{l}\text { Double batched boat in } \\
\text { boat dock }\end{array}$ & Mass & $\begin{array}{l}\text { Operator } \\
\text { training/procedure/inventory } \\
\text { control }\end{array}$ & $\begin{aligned} & \mathrm{k}_{\mathrm{eff}}=0.8860 \\
& \sigma=0.0005 \\
&(\mathrm{cc} 3)\end{aligned}$ \\
\hline $\begin{array}{l}\text { Boat stacked on two } \\
\text { other boats }\end{array}$ & $\begin{array}{l}\text { Mass } \\
\text { Interaction }\end{array}$ & Operator training/procedure & $\begin{aligned} & \mathrm{k}_{\mathrm{eff}}=0.8871 \\
& \sigma=0.0006 \\
&(\mathrm{cc} 4)\end{aligned}$ \\
\hline $\begin{array}{l}2 \times 2 \text { boat array in a } \\
\text { corner of the glovebox }\end{array}$ & $\begin{array}{l}\text { Mass } \\
\text { Volume }\end{array}$ & & $\begin{aligned} & \mathrm{k}_{\mathrm{eff}}=0.9312 \\
& \sigma=0.0005 \\
&(\mathrm{cc} 103)\end{aligned}$ \\
\hline Aggregate of containers & $\begin{array}{l}\text { Mass } \\
\text { Volume }\end{array}$ & Operator training/procedure & $\begin{aligned} & \mathrm{k}_{\mathrm{eff}}=0.8864 \\
& \sigma=0.0005 \\
&(\mathrm{cwcc} 7)\end{aligned}$ \\
\hline $\begin{array}{l}\text { Container with } 4.5 \mathrm{~kg} \\
\text { of Pu brought up to } \\
\text { outside of glovebox }\end{array}$ & Interaction & Operator training/procedure & $\begin{aligned} \mathrm{k}_{\text {eff }}=0.9105 \\
\sigma=0.0006 \\
(\mathrm{cc} 7)\end{aligned}$ \\
\hline $\begin{array}{l}\text { Double batched filter } \\
\text { basin mass of } 5.5 \mathrm{~kg} \mathrm{Pu}\end{array}$ & Mass & $\begin{array}{l}\text { Operator } \\
\text { training/procedure/inventory } \\
\text { control }\end{array}$ & $\begin{aligned} & \mathrm{k}_{\mathrm{eff}}=0.8741 \\
& \sigma=0.0005 \\
&(\mathrm{cc} 8)\end{aligned}$ \\
\hline $\begin{array}{l}\text { Interspersed } \\
\text { moderation at full water } \\
\text { density without glass } \\
\text { tanks breaking }\end{array}$ & $\begin{array}{l}\text { Moderation } \\
\text { Reflection }\end{array}$ & $\begin{array}{l}\text { Requires glovebox windows } \\
\text { breaking by seismic or major } \\
\text { fire, both unlikely. } \\
\text { Tank spacing protected by } \\
\text { configuration management. }\end{array}$ & $\begin{aligned} & \mathrm{k}_{\text {eff }}=0.9410 \\
& \sigma=0.0014 \\
&(\mathrm{cc} 1121)\end{aligned}$ \\
\hline
\end{tabular}


HNF-6537 REV. 0

\begin{tabular}{|l|l|l|l|}
\hline $\begin{array}{l}\text { Contingency } \\
\text { Description }\end{array}$ & $\begin{array}{l}\text { Affected } \\
\text { Criticality } \\
\text { Parameter(s) }\end{array}$ & $\begin{array}{l}\text { Barriers that make } \\
\text { contingency unlikely }\end{array}$ & $\begin{array}{l}\mathbf{k}_{\text {eff }} \\
\text { bounding } \\
\text { contingency } \\
\text { (case ID) }\end{array}$ \\
\hline $\begin{array}{l}\text { Seismic event reduces } \\
\text { spacing between } \\
\text { precipitation tanks }\end{array}$ & $\begin{array}{l}\text { Interaction } \\
\text { supply. }\end{array}$ & $\begin{array}{l}\text { Seismic event unlikely. } \\
\text { Tank diameter protected by } \\
\text { configuration management. }\end{array}$ & $\begin{array}{l}\mathrm{k}_{\text {eff }}=0.9207 \\
\sigma=0.0014 \\
\text { (ncs2) }\end{array}$ \\
\hline $\begin{array}{l}\text { Uranium enrichment } \\
\text { greater than 50 wt } \%\end{array}$ & Enrichment & $\begin{array}{l}\text { Feed limited to less than } 50 \\
\text { wt \% uranium. } \\
\text { Feed limited to less than } 100\end{array}$ & $\begin{array}{l}\text { Bounded by } \\
\text { evaluated Pu } \\
\text { concentration } \\
\text { of 100 g Pu/L. }\end{array}$ \\
\hline Fire & $\begin{array}{l}\text { Moderation } \\
\text { Reflection }\end{array}$ & $\begin{array}{l}\text { Major building fire that } \\
\text { breaks glovebox windows to } \\
\text { allow sprinkler water in is } \\
\text { unlikely. } \\
\text { Criticality drain limits water } \\
\text { level. }\end{array}$ & $\begin{array}{l}\text { Bounded by } \\
\text { seismic } \\
k_{\text {eff }}=0.9359 \\
\sigma=0.0005 \\
\text { (cc5) } \\
\text { and } \\
\text { interspersed } \\
\text { water } \\
\mathrm{k}_{\text {eff }}=0.9410 \\
\sigma=0.0014 \\
\text { (cc1121) }\end{array}$ \\
\hline
\end{tabular}

\subsection{SUMMARY}

This CSER shows that the designed magnesium hydroxide process controlled to the limits listed in Section 3.0 is acceptable in Glovebox 3. No single credible event causes the $\mathrm{k}_{\text {eff }}$ criticality safety limit of 0.95 to be exceeded. All the contingency calculations meet the calculational limit of $\mathrm{k}_{\text {eff }}=0.942$ specified in Appendix B which is used to account for bias and computational uncertainty. Therefore, this CSER meets the requirements of the Double Contingency Principle for a criticality safety analysis specified in the Hanford Site Nuclear Criticality Safety Manual (HNF-PRO-539). 
HNF-6537 REV. 0

This page intentionally left blank. 


\subsection{SYSTEM DESCRIPTION AND NORMAL OPERATION}

This section gives a system description of the magnesium hydroxide process, including both the precipitation stream and the interim filtrate storage. A schematic diagram for this process is shown in Figure 2-1.

\subsection{SYSTEM DESCRIPTION}

The operation begins with loading in plutonium nitrate solutions to the blend tanks in the preparation Glovebox HC-227S. The solutions are sampled, blended, and adjusted with dilute $\mathrm{HNO}_{3}$ to meet the blend plan for precipitation in Glovebox 3.

The adjusted feed material is pumped to three precipitator tanks in Glovebox 3, where an amount of dry $\mathrm{Mg}(\mathrm{OH})_{2}$ powder calculated to neutralize the batch of feed solution (plus a $5 \%$ excess to assure complete plutonium precipitation) and about a teaspoon of flocculent are added to each precipitator tank. The solution is agitated for a given period of time with air drawn through the solution by the glovebox vacuum system eductor. The precipitate and filtrate is drained to a filter, where the liquid (filtrate) is drawn off to the phase separator tank using the glovebox vacuum system. If the filter pan does not drain, fissionable material will overflow the filter basin to the floor of the glovebox. The event of having fissionable material on the glovebox floor is analyzed.

When the liquid has drained from the precipitate cake, the cake is manually scraped off the filter into a standard furnace boat, which is placed on a hot plate to reduce the water content of the cake. A scale will be available inside the glovebox to determine the mass in a boat. After the cake is dried, the boat is moved to a boat dock or to the conveyor and transported to other gloveboxes for thermal stabilization.

The filtrate is pumped from the phase separation tank through one of a pair of polishing filters to one of three pairs of filtrate tanks in Glovebox 4 . The filtrate is circulated through Glovebox 3 to be sampled for analysis of the plutonium concentration. If the filtrate analysis meets disposal specification limits, the filtrate will be drained to $241-Z$ or to another facility for storage and disposal. If the filtrate analysis does not meet disposal limits, it can be pumped (recycled) back to the precipitator tanks, or through the polishing filters, or pumped among the filtrate tanks for blending. The polishing filters have pressure differential instrumentation to show when to change out the filters. The vacuum catch tank and vacuum trap tank would not be expected to collect significant fissionable material during normal operations, but they are filled with fissionable material for the contingency case cc2c (Section 5.3). 
HNF-6537 REV. 0

\subsection{FACILITY AND EQUIPMENT DESCRIPTION} 1999):

The magnesium hydroxide precipitation process includes the following subsystems (Zook

\section{Feed Preparation}

Plutonium feed is received in solution containers (e.g., PR cans, 10Ls, etc.) and transferred to blend tanks in Glovebox HC-227S using the plant vacuum system. The blended feed solution is then pumped to the magnesium hydroxide process precipitate tanks in Glovebox 3 by an existing air operated diaphragm pump through a single encased transfer line (a pipe-within-apipe).

Glovebox 3 does not have limits on molarity of nitric acid for temperature ranges because it is not considered credible that plutonium solutions that are susceptible to polymerization can be blended and then pumped to Glovebox 3. Polymerization would occur in the blend glovebox or in the transfer line before reaching Glovebox 3. Glovebox HC-227S where the fissionable solutions are blended has limits on nitric acid concentration to prevent plutonium polymerization.

\section{Precipitate}

The chemical conversion of plutonium nitrate to a plutonium precipitate of plutonium hydroxide occurs when magnesium hydroxide changes the solution from an acid holding the plutonium in solution to a basic medium. The following reactions occur:

$$
\begin{gathered}
2 \mathrm{HNO}_{3}+\mathrm{Mg}(\mathrm{OH})_{2}(\mathrm{~s}) \rightarrow \mathrm{Mg}\left(\mathrm{NO}_{3}\right)_{2}+2 \mathrm{H}_{2} \mathrm{O} \\
\mathrm{Pu}\left(\mathrm{NO}_{3}\right)_{4}+2 \mathrm{Mg}(\mathrm{OH})_{2}(\mathrm{~s}) \rightarrow 2 \mathrm{Mg}\left(\mathrm{NO}_{3}\right)_{2}+\mathrm{Pu}(\mathrm{OH})_{4} \downarrow
\end{gathered}
$$

When the precipitate has settled, a sample is taken from the precipitators to ensure that the solution is above a $\mathrm{pH}$ of 6.2 . This minimum $\mathrm{pH}$ controls the maximum concentration of plutonium that can remain in solution. Although the plutonium concentration remaining in solution is not measured at this point, if the $\mathrm{pH}$ is above the minimum value, the plutonium remaining in solution would meet the waste treatment facility ultimate disposal acceptance criteria.

\section{Vacuum transfer and filtration}

The slurry of precipitate and solution in the precipitation tanks will be gravity drained to the vacuum filter to separate the plutonium precipitate from the filtrate stream. The vacuum on the filter will pull the filtrate through the filter while leaving the plutonium hydroxide solids on the filter media. The filtrate will be collected in a phase separator (disengaging pot) to remove the entrained air from the filtrate prior to pumping this material through polishing filter and into the filtrate tanks in Glovebox 4. 


\section{Drying on the hot plate}

Operators will scrape the plutonium filter cake into a boat. The boat is then placed on a hot plate to reduce the moisture content. The boat containing the plutonium solids will then be transferred to a muffle furnace in another glovebox via conveyor. A worn out filter is dried on the vertical line and bagged out as waste.

\section{Filtrate transfer and polishing filters}

The filtrate will be pumped through one polishing filter. These polishing filters contain a sock filter to catch smaller particles of plutonium hydroxide that passed through the vacuum filter. The two filters are in parallel to allow switching from one filter to the other when an excessive pressure drop indicates one filter is full. The polishing filters have pressure differential instrumentation installed. When a predetermined pressure drop is reached, the filter media is to be changed out. The filter housing will normally be drained of solution prior to the removal of the filter media. The polishing filter media will be dried on the vertical lines and bagged out as waste.

\section{Disposal}

The filtrate solution will be sampled in Glovebox 3 for plutonium content prior to transfer to building $24 \mathrm{I}-\mathrm{Z}$ or other facility for disposal. The filtrate is circulated back from Glovebox 4 to Glovebox 3 for sampling because Glovebox 3 has a pass through to a conveyor to send the sample to a convenient bag out port outside the magnesium hydroxide process room. Bagging out a sample requires the room to go on mask, which decreases process efficiency. The filtrate will be returned to the precipitators, polishing filters, or blended with filtrate in other filtrate tanks should the plutonium concentration be greater than the filtrate disposal limit. A mass or concentration limit may be established to conform to the Hanford waste tank acceptance limits.

\section{Equipment Description}

Glovebox 3 major components and their designed dimensions are summarized in Table 2-1. The glovebox has process inputs of feed solution, magnesium hydroxide and flocculent, control signals for the valves and the pump, electrical power, process water for flushing, and compressed air system to operate the transfer pump and vacuum eductor and process outputs of dried precipitation cake in boats, waste filtrate, feed and filtrate samples, bagged waste, and glovebox air. 
Table 2-1. Facility and Equipment Dimensions

\begin{tabular}{|c|c|}
\hline Containers & Dimensions \\
\hline Glovebox & $\begin{array}{l}426.72 \mathrm{~cm}(14 \mathrm{ft}) \text { long } \times 198.12 \mathrm{~cm}(6.5 \mathrm{ft}) \text { tall } \times 106.68 \mathrm{~cm} \\
(3.5 \mathrm{ft}) \text { depth (inside dimensions) }\end{array}$ \\
\hline Precipitator Tanks & $\mathrm{TK}-001 \mathrm{~A} / \mathrm{B} / \mathrm{C}, 6.186$ in. $\max \mathrm{ID} \times 41.5 \mathrm{in} . \mathrm{T} / \mathrm{T}, 20 \mathrm{~L}$ \\
\hline Phase Separator Tank & TK-004, $\quad 6.186$ in $\max$ ID $\times 43$ in. $T / \mathrm{T}, 20 \mathrm{~L}$ \\
\hline Vacuum Trap Tank & 6.186 in. $\max 1 \mathrm{D} \times 22$ in. \\
\hline Vacuum Catch Tank & 6.186 in. $\max$ ID $\times 12$ in. \\
\hline Vacuum Filter Basin & 17 in dia. $\times 2$ in deep \\
\hline Filter Drying Line & 17 in dia. $x \sim 3 / 16$ in. thick dry plastics \\
\hline Polishing Filter & $\begin{array}{l}6 \text { in. dia. } \times 15.5 \text { in. duplex } \\
\text { (1 operating, } 1 \text { standby) }\end{array}$ \\
\hline Drip Pan & $1^{\prime} \times 1-1 / 2 \times 2$ in. or 12 in. $\times 18$ in. $\times 2$ in. \\
\hline Hot Plate Boat & 11 in. $\times 5$ in $\times 2.5$ in., $2.3 \mathrm{~L}$ (nominal inner dimensions) \\
\hline Furnace Boat & 11 in. $\times 5$ in $\times 2.5$ in., $2.3 \mathrm{~L}$ (nominal inner dimensions) \\
\hline Storage Boat Dock & $2.54 \mathrm{~cm}$ ( 1 in.) sq. steel bar welded to glovebox floor \\
\hline Sweeps Can & $0.5 \mathrm{~L}$ (geometry: $\mathrm{h}=\mathrm{d}=8.6 \mathrm{~cm})$ \\
\hline Trash Bag & 1 to 2 grams of fissionable material on plastic and equipment \\
\hline Transfer Pump & P- $001,6.7$ in dia. $\times 8$ in. wide with fluid capacity of $0.15 \mathrm{~L}$ \\
\hline
\end{tabular}

The $\mathrm{T} / \mathrm{T}$ designator used for the glass pipe tanks above is the length of the cylindrical section. This designation excludes the conical bottom portion of the tank from its length.

\subsection{FISSIONABLE MATERIALS DESCRIPTION}

Table 2-2 recaps the fissionable material contents for each component under normal operating conditions. The modeled materials under normal, base, and contingency cases are described in Section 5.0. All plutonium and fissionable uranium are modeled as ${ }^{239} \mathrm{Pu} .{ }^{235} \mathrm{U}$ may be substituted for ${ }^{239} \mathrm{Pu}$ on a gram for gram basis as stated in PFP Criticality Prevention Specification CPS-Z165-80010, entitled General Limits.

No restrictions are placed on other solids in the precipitate or elements in the solution, except fissionable isotopes, because water is the most effective moderator. Figure 46 in LA-10860-MS shows that water mixed with fissionable material is more reactive than mixing any one of the following with fissionable material: beryllium; beryllium oxide; heavy water; or carbon.

Each of the six glass tanks is surrounded by a cylinder of stiff wire mesh (i.e. hardware cloth) that protects the glass tanks from impact by moving tools or equipment within the glovebox. The wire mesh cylinder is mounted on the outside circumference of flanges at the top and bottom of the tanks. This wire mesh would keep hands, flexible plastic tubing, and other solid reflectors spaced at least $3.8 \mathrm{~cm}$ (1.5 in.) from the fissionable solution in the tanks. 
Table 2-2. Fissionable \& Moderator Material Contents for Normal Operation Condition

\begin{tabular}{|c|c|}
\hline Containers & Contents \\
\hline Glovebox & $\begin{array}{l}1 / 8 \text { in. thick layer of } 3 \mathrm{~g} \mathrm{Pu} / \mathrm{cm}^{3} \text { as } \mathrm{PuO}_{2} \text { on floor as overly } \\
\text { conservative model of possible holdup. }\end{array}$ \\
\hline Precipitator Tanks & $2.5 \mathrm{~kg}$ of plutonium nitrate solution in three tanks. \\
\hline Phase Separator Tank & $1 \times 10^{-3} \mathrm{~g}$ Pu/L solution fill the tank, $20 \mathrm{~L}$ high \\
\hline Vacuum Trap Tank & $1 \times 10^{-3} \mathrm{~g} \mathrm{Pu} / \mathrm{L}$ solution fill the tank, $11 \mathrm{~L}$ high \\
\hline Vacuum Catch Tank & $1 \times 10^{-3} \mathrm{~g} \mathrm{Pu} / \mathrm{L}$ solution fill the tank, $5 \mathrm{~L}$ high \\
\hline Vacuum Filter Basin & $\begin{array}{l}2.5 \mathrm{~kg} \text { Pu in filter as precipitate cake with } 50 \mathrm{wt} \% \text { moisture; } \\
2 \mathrm{in} \text {. depth allowed by basin side height. }\end{array}$ \\
\hline Filter Drying Lines & No Pu (Minimal Pu during normal operations) ${ }^{*}$ \\
\hline Polishing Filter & $1 \times 10^{-3} \mathrm{~g} \mathrm{Pu} / \mathrm{L}$ solution filled \\
\hline Drip Pan & No $\mathrm{Pu}$ ( $1 / 8$ in. floor accumulation bounds $\mathrm{Pu}$ in drip pan) \\
\hline Furnace Boat on Hot Plate & $2.5 \mathrm{~kg}$ Pu metal mixed with water and filling a $2.3 \mathrm{~L}$ boat. \\
\hline Boat in Transit & $2.5 \mathrm{~kg}$ Pu metal mixed with water and filling a $2.3 \mathrm{~L}$ boat. \\
\hline Boats in Boat Dock & $\begin{array}{l}\text { Two boats each with } 2.5 \mathrm{~kg} \mathrm{Pu} \text { metal mixed with water and filling } \\
\text { the } 2.3 \mathrm{~L} \text { boats. }\end{array}$ \\
\hline Sweeps Can & $1.5 \mathrm{~kg}$ at $3 \mathrm{~g} \mathrm{Pu} / \mathrm{cm}^{3}$ in $\mathrm{PuO}_{2}$ \\
\hline Trash Bag & No Pu (Floor holdup bounding conservatism) \\
\hline Transfer Pump & Other items bound glovebox fissionable material loading in filtrate \\
\hline $\mathrm{HEPA}$ & 1 in. of water at roof conservatively bounds HEPA Pu content \\
\hline
\end{tabular}

* Plutonium added to filter basin in place of filter medium as a conservatism.

\subsection{MISCELLANEOUS EQUIPMENT IN THE GLOVEBOX 3}

The glovebox has piping connected to the vacuum catch tank to remove liquid from the floor of Glovebox 3. A piece of tygon tubing attached to piping from the vacuum catch tank is used if needed to recapture leaked liquids. The $1.27 \mathrm{~cm}(1 / 2 \mathrm{in}$.) inside diameter tubing is not modeled explicitly. The tanks are modeled with $0.2794 \mathrm{~cm}(0.11 \mathrm{in}$.) larger inside diameter than the maximum tolerance. This conservatism includes the possible effect of the tubing getting close to a tank.

The enclosed pipeway from the blend tanks in Glovebox HC-227S ends with a drain line from the top of the glovebox to a one-liter polybottle on the glovebox floor in a corner. The line and bottle are part of a leak detection system for the interglovebox pipeway. The $1.27 \mathrm{~cm}(1 / 2$ in.) inside diameter tubing and polybottle are not modeled explicitly. The conservative tank diameter containing extra solids and feed solution is considered to account for the interaction of this tubing also. The three-inch transfer pipeway ends at the top of the glovebox and is remote from a tank. The glovebox air exhaust HEPA filter is located adjacent to the HC-227S pipeway connection to Glovebox 3. The contingency of the external can being brought adjacent to the glovebox is considered to bound the pipeway filling with filtrate. The pump surge tank is not 
explicitly modeled, however the vacuum catch and trap tanks are larger in diameter and longer and are filled with filtrate in the base case. The two tanks are considered to bound the pump surge tank volume.

The glovebox is supported by a stand. This stand has cross bracing and small enough openings to preclude casual operator access beneath the glovebox. A brace along the floor would prevent wagon access below the glovebox and may stop a plutonium can from rolling under the glovebox, although a can could be dropped between the bracing and end up under the glovebox. Inclusion of full water reflection at the floor of the glovebox for the base case and contingencies is considered bounding.

The pump in Glovebox HC-227S can pump feed solution to precipitator tanks in Glovebox 3 or to the floor in Glovebox 3 if a vent valve is opened accidentally or two valves are misaligned. If a leak develops in the pump, piping, or process vessels, the filtrate will drip to the floor of a glovebox. There are no other locations that the pump can send the filtrate to that are critically less favorable than the precipitator tanks or the floor of the glovebox. If fissionable solutions and rinse water are being dumped to the glovebox floor, the criticality drain maintains a subcritical depth of liquid on the glovebox floor. The only path to the phase separator tank is thru the vacuum filter basin. All paths require an operator to hold a flexible tubing to direct a fluid stream into the basin. Then, to transfer material from the phase separator tank to the filtrate tanks in Glovebox 4 for disposal, requires a pump and proper alignment of more than two valves. The process piping configuration does not allow transfer of feed solution to Glovebox 4 inadvertently.

A $7.62 \mathrm{~cm}$ ( 3 in.) thick, flat, borated polyethylene shield four feet tall is located between the vacuum filter basin and the nearest precipitator tank. The stainless steel encased shield is about $15.24 \mathrm{~cm}(6 \mathrm{in}$.) from both the tank and basin. The absorption of the boron and steel is conservatively left out of the analysis. The reflection of the 12 in. of water modeled at the sides of the glovebox is considered to include the effect of this shield.

Two types of sample connections to process piping allow sampling the filtrate being sent to Glovebox 4 for disposal and the feed solution in each of the precipitator tanks. The samples are collected in $30 \mathrm{~mL}$ sample bottles and sent to lab for analysis via the conveyor or the sample bottle sphincter port. The conservatism of tank diameter, the $1 / 8^{\prime \prime}$ floor layer of plutonium oxide, and the reflection around the glovebox are considered to cover movement of up to $50 \mathrm{~mL}$ sample bottles around the glovebox.

Glovebox 5, the pass through between Glovebox 3 and conveyor HC-3, begins its first section at about 8 in. above the glovebox floor oriented perpendicular to the long glovebox axis. In about a foot, the connection makes a left turn to the conveyor about two feet away with another 8 in. step. A boat located around the corner would not be expected to get back into the glovebox in an earthquake, but one in the first section could.

The vacuum filter drying lines are located along the center line of the glovebox behind the vacuum filter basin. Two loops of thick monifiliment are stretched between pulleys at the top and bottom of the glovebox. This arrangement allows the used filters to be attached at the 
operating elevation and then raise above the working elevation. The filters remain over the drip pan on the floor of the glovebox.

\subsection{CONTAINERS}

Gloveboxes 3 and 5 have boats, sample bottles, pipeway leak detection bottle, and trash bundles. The boats have inside dimensions of $107 / 8 \mathrm{in}$. long, $5 \mathrm{in}$. wide, and $27 / 16 \mathrm{in}$. high. It has two 5/16 in. diameter holes at each end whose edge is $13 / 4$ in. from the outside bottom of the boat. A boat may be used to move the sample bottles in and out of the glovebox. The sample bottles are expected to have a volume of $30 \mathrm{~mL}$. Operators expect to need a dozen sample bottles in the glovebox. The nominal one liter leak detection bottle is located in a corner of the glovebox near the tanks. A flexible plastic tube connects the tap on the pipeway from HC-227S to the leak detection bottle. Trash bundles remove surplus material from the glovebox. They are expected to contain ice cream cartons that brought in the magnesium hydroxide and floculent, the dried vacuum basin filters, and dried sock filters from the polishing filter. These items are projected to carry only a few grams of plutonium. 
HNF-6537 REV. 0

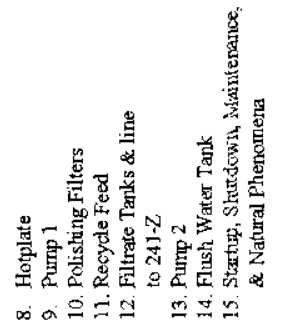

है

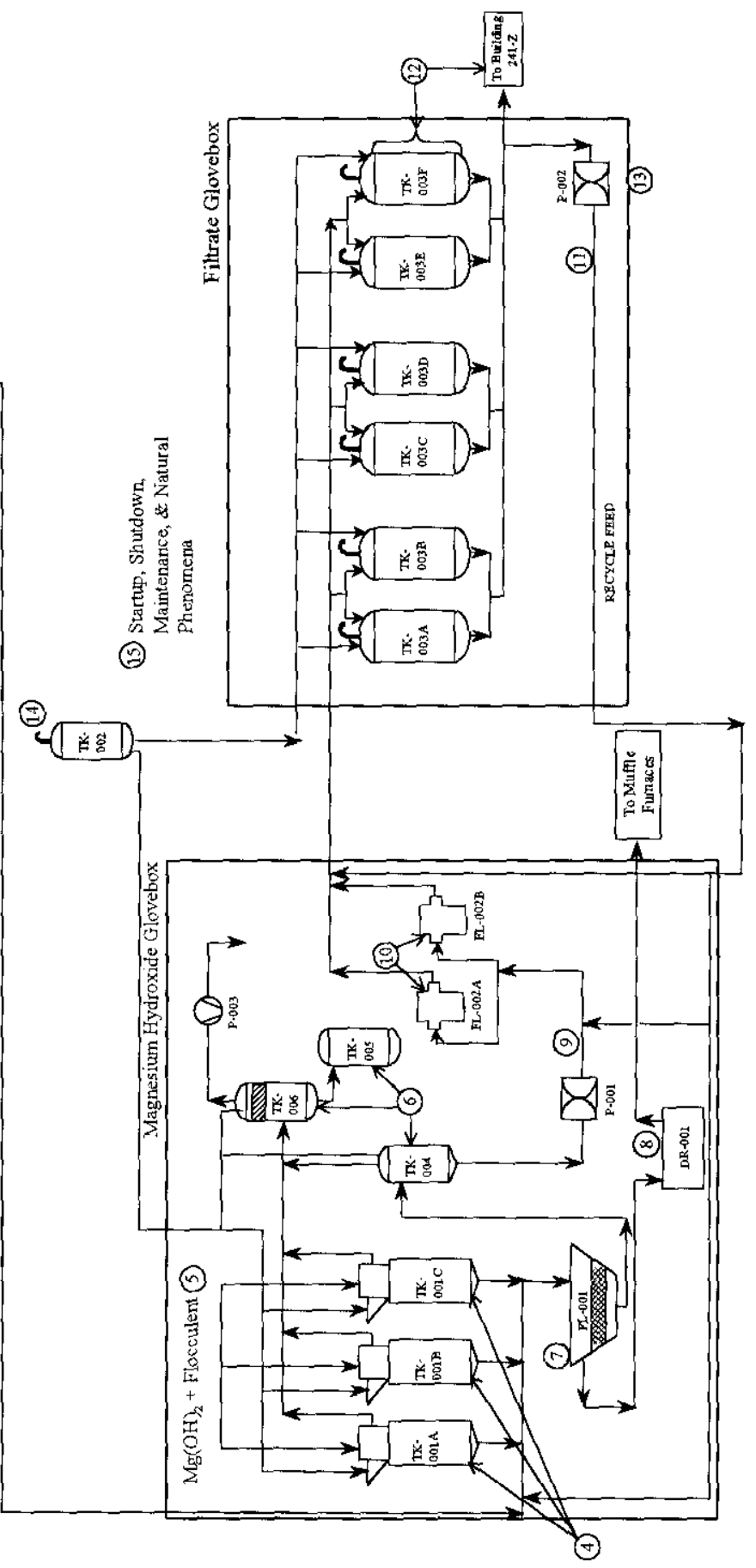




\subsection{LIMITS AND CONTROLS}

This section identifies the controlled parameters and their associated limits upon which nuclear criticality safety depends. The dimensions required for safe handling of fissionable material are listed in the engineered safety features section.

\subsection{LIMITS}

- Maximum total mass of plutonium in the three precipitation tanks is $2.5 \mathrm{~kg}$, which may be met by controlling the volume and concentration of the feed solution.

- Maximum plutonium concentration in the feed solution is $100 \mathrm{~g} \mathrm{Pu} / \mathrm{L}$.

- Maximum mass of plutonium per unit mass (batch) is $2.5 \mathrm{~kg}$.

- Maximum of one (1) batch in vacuum filter basin.

- Maximum of one (1) batch per boat and each upright boat is considered to contain a batch.

- Maximum number of boats as containers allowed in Glovebox 3 is 4 . One boat of the four boats may be anywhere except within $25.4 \mathrm{~cm}$ ( $10 \mathrm{in}$.) of the tanks in Glovebox 3 . The remaining boats are to be in the boat dock(maximum of two (2) boats), on the hot plate [maximum of one (1) boat], or adjacent to the vacuum filter basin [maximum of one (1) boat].

- Maximum number of containers allowed in Glovebox 5 is one (1) boat and all other containers allowed in Glovebox 3.

- Maximum uranium enrichment is $50 \mathrm{wt} \% \mathrm{U}-235$.

- No boat or container of fissionable material is to be brought into Glovebox 3 or 5 that did not originate in Glovebox 3.

- Maximum volume of fissionable material allowed in boats is $2.3 \mathrm{~L}$.

- Twelve fissionable material bearing sample bottles of up to $50 \mathrm{~mL}$ and any number of empty, closed sample bottles are allowed anywhere in the glovebox. Sample bottles may be moved in a boat or in a container of up to a nominal $1 \mathrm{~L}$ volume.

- One sweeps container of nominal $0.5 \mathrm{~L}$ volume is allowed.

- One leak detection bottle of nominal $1 \mathrm{~L}$ volume is allowed.

- Three $250 \mathrm{~mL}$ nominal containers with precipitator solution are allowed for $\mathrm{pH}$ determination.

- A total of four (4) vacuum basin filters and/or sock filters from the polishing filters are allowed on the drying lines and in Glovebox 3.

- Drip pan below the vacuum filter drying rack is limited to $5.08 \mathrm{~cm}(2.0 \mathrm{in}$.) depth.

\subsection{PROCESS CONTROLS}

- Noticeable accumulation of spilled fissionable material on the glovebox floor or filter drip pan shall be cleaned up as soon as practical.

- Operations is to make two independent determinations of the fissionable material concentration in each batch of feed solution sent to Glovebox 3 . 
- Boats are prohibited to be stored under the precipitator and other tanks or in Glovebox 5 before the corner or within $25.4 \mathrm{~cm}$ (10 in.) of the $\mathrm{HC}-3$ conveyor.

- Heaping in the furnace boats or vacuum filter basin is to be smoothed below the side wall height as soon as practical.

- Damp rags (maximum of 6 square feet total area) may be present in the glovebox for cleaning purposes.

- Non-fissionable material bearing boats and containers are to be made non-containers, turned upside down, or kept 25.4 (10 in.) edge-to edge from other fissionable material.

- No stacking of plutonium bearing containers or boats is allowed.

- HEPA prefilter change out is allowed only when tanks are empty and all fissionable materials are removed from the glovebox except holdup.

- Polishing filters with more trapped precipitate than normal are to be changed out under the guidance of the PFP Criticality Safety Representative.

- No storage of fissionable or reflecting materials below the glovebox floor is allowed.

- Criticality drain is to be visually inspected periodically to be unobstructed to the flow of water.

- No pressurized plant water system piping system piping is allowed in Glovebox 3 .

- Gloveboxes 3 and 5 are to be Fire Fighting Category C.

\subsection{ENGINEERED SAFETY FEATURES}

- Glovebox is seismically qualified to remain standing in a DBE (Design Basis Earthquake).

- Glovebox 3 has a criticality drain that limits introduced water to a $7.62 \mathrm{~cm}(3.0 \mathrm{in}$.) depth.

- Minimum spacing between the six tanks is $25.4 \mathrm{~cm}$ (10 in.) glass edge-to-edge. Three precipitation tanks are to be in a line.

- Tanks are limited to $111.76 \mathrm{~cm}$ (44 in.) inside height and a maximum inside diameter of $15.748 \mathrm{~cm}(6.2 \mathrm{in}$.).

- The vacuum filter basin is restricted to have a maximum depth of $7.874 \mathrm{~cm}(3.1 \mathrm{in}), 5.334$ $\mathrm{cm}(2.1 \mathrm{in}$.) above and $2.54 \mathrm{~cm}$ ( $1.0 \mathrm{in}$.) below the perforated filter support plate, and to a maximum inside diameter of $43.434 \mathrm{~cm}(17.1 \mathrm{in}$.). 


\subsection{METHODOLOGY}

\subsection{MCNP4B VERIFICATION \& VALIDATION}

The Monte Carlo Code MCNP Version 4B, was certified (Schwinkendorf 1998) and validated (Erickson 1998 and Lan 1999) for plutonium such as the operation in this glovebox. Room temperature cross sections were used for the MCNP calculations. Some experimental data indicate that Pu-239 may have a very small positive (on the order of $10^{-5}$ to $10^{-6} \mathrm{\Delta k} / \mathrm{k} /{ }^{\circ} \mathrm{C}$ ) reactivity response to increasing temperature (Hummel 1978). This is insignificant compared with the typical statistical uncertainty of 0.002 for the MCNP calculations. Only under normal conditions are the hot plate boats heated to $550^{\circ} \mathrm{F}$ on the hot plate. The heating on the hot plate drives off water, reducing the $\mathrm{H} / \mathrm{X}$ ratio. The heating also slightly expands the physical dimensions for the fissionable material according to the temperature coefficient of expansion. Both of these phenomena decrease reactivity, but were not included in the analyses. Therefore, room temperature cross sections and material densities are the most appropriate to compare with safety limits.

A summary of the validation of MCNP4B is included in Appendix B, MCNP4B Computer Code Validation, which determines a maximum allowable $\mathrm{k}_{\text {eff }}$ value of 0.942 for non-metal and 0.932 for metal system calculations. These values are for calculations with statistical uncertainties of $\leq \pm 0.002$ and assure subcriticality with an acceptable margin, including the uncertainties in the analytical methods and benchmark experimental data.

\subsection{SUB-CRITICAL LIMIT}

For the purpose of this report, the principal criticality prevention criterion or parameter is that the effective neutron multiplication (or criticality) factor $\left(k_{\text {eff }}\right)$ shall not exceed 0.95 (i.e., $k_{\text {eff }}$ $\leq 0.95$ ) for all permitted normal configurations of materials, containers, etc., and for any credible off-normal event. This criterion is based on implementing the applicable DOE Order 5480.24 (DOE 1992), ANSI standards(ANSI/ANS-8. 1 1998), and HNF-PROs (FDH 1997, FDH 1997a, and FDH 1997b). The subcriticality is used to judge the acceptability of a calculated $k_{\text {eff }}$ value for fissionable material configuration. This criterion must account for the bias inherent in the code and cross sections used, any uncertainties in the physical problem being analyzed, and the uncertainties in both the bias determination (the experimental basis) and the calculational methods.

\subsection{APPLICATION OF DOUBLE CONTINGENCY PRINCIPLE}

This analysis must meet the requirements of HNF-PRO-334, Criticality Safety General Requirements (FDH 1997), HNF-PRO-537, Criticality Safety Control of Fissionable Material (FDH 1997a), and HNF-PRO-539, Criticality Safety Evaluations (FDH 1997b). HNF-PRO-539 states that for all new operations and changes pertinent to criticality safety issues in existing operations, the CSER is required to demonstrate that there is an acceptable margin of 
subcriticality for all normal and credible abnormal conditions. To demonstrate the Double Contingency Principle is satisfied, this CSER must show that there are sufficient factors of safety in the operation of Glovebox 4 such that at least two unlikely, independent, and concurrent changes in process conditions are required before a criticality accident is possible.

\subsection{HAZARDS ASSESSMENT}

Identification of the contingencies for the operation described in Section 2 and evaluated in Section 5 used a hazards assessment technique called a hazard assessment. The goal of this effort is to identify deviations from the planned operation that may pose a challenge to criticality safety. Analysis is done, as necessary to demonstrate that each identified condition is adequately subcritical.

In a hazard assessment, an interdisciplinary team uses a disciplined, systematic approach to identify hazards and deviations that could lead to undesirable consequences. Because the criticality safety concerns usually arise from deviations from the process design, an experienced team leader systematically guides the team through the planned operation. Off-normal events are identified and separated into likely and unlikely to happen during the lifetime of the operation. The likely events become part of the base case and unlikely events are the contingencies of Section 5. The details of these assessment results are presented in Appendix D.

\subsection{ASSUMPTONS}

The following assumptions were made in carrying out the analysis in the CSER.

- Fissionable material is all Pu-239.

- The filter is conservatively left out of the filter basin in determining the depth of material in the vacuum filter basin.

- $2.25 \mathrm{~L}$ used for nominal 11 in. $\times 5$ in. $\times 2.5$ in. furnace boat.

- The hot plate is to be covered by a borated polyethylene and steel encasement to shield operators from radiation. The shield increases the neutron reflection to the boat. An analysis of the shielding is documented in Appendix $G$. The hot plate alone (case nca 12) has a $k_{\text {eff }}$ comparable to that of the glovebox (cases nca and ncb) when boron is not modeled in the polyethylene. When $5 \%$ boron is included (case ncbbo) in the polyethylene, the reactivity drops substantially. The neutron absorber is not included in either the base case or the contingency analyses.

- The concentration for the maximum reactivity of plutonium nitrate solution is $250 \mathrm{~g} \mathrm{Pu} / \mathrm{L}$ (Carter 1968).

- It is not considered credible to have plutonium nitrate spray into the glovebox from the vacuum eductor during normal operation or during a seismic event. Solution would have to over flow two tanks in series to reach the eductor.

- A $15.2 \mathrm{~cm}$ ( $6 \mathrm{in}$.) depth of solids in the precipitator tanks is the maximum credible. If a full tank of $20 \mathrm{~L}$ of $450 \mathrm{~g} \mathrm{Pu} / \mathrm{L}$ precipitated at $3 \mathrm{~g} \mathrm{Pu} / \mathrm{cm}^{3}$, the depth would be less than $15.2 \mathrm{~cm}$ (6 in.). Multiple batches of precipitate in the tanks is not considered credible because if the 
precipitate did not flow out it would block the filtrate and there would not be room to bring in more feed solution to process.

- It is not credible to have a precipitate with a density greater than $3 \mathrm{~g} \mathrm{Pu} / \mathrm{cm}^{3}$. Experimental data found that the plutonium hydroxide precipitate density from the magnesium hydroxide process is normally about $0.2 \mathrm{~g} \mathrm{Pu} / \mathrm{cm}^{3}$ as reported in Appendix $\mathrm{H}$.

- The number of gloves and screening around tanks keeps operator hands to 1 in. of reflection along a 6 in. length of tank at a time.

- Rinse water line delivers less than 6 gpm.

- The neutron absorption of the boron in the glass tanks and in the hot plate shield and of the metals in the boats is not included in the model. Leaving the absorbers out of the model is part of the defense in depth of a conservative analysis.

- A sock filter in a polishing filter accumulates a nominal $1 / 8$ in. thickness of solids before the pressure drop increases to block fluids being pumped thru the filters. 
HNF-6537 REV. 0

This page intentionally left blank. 


\subsection{EVALUATION AND ANALYSIS}

\subsection{NORMAL CASE}

Table 5-1-1 lists the dimensions of modeled equipment. These dimensions are conservative compared to the design dimensions listed in Table 2-1 to cover tolerances and corrosion. Figure E-1 shows the top view of the glovebox and equipment arrangement. Figure E-2 shows the component names and equipment numbers used in the Process Flow Diagram (H-2-829761). Based on the fissionable material description shown in Table 2-2 of Section 2.3, the calculated mixture densities and material weight fractions are shown in Table 5-1-2. The table also lists the $\mathrm{H} / \mathrm{X}$ ratios of the materials in the containers and tanks. The reflector materials and their modeling locations are listed in Table 5-1-3. These three basic parameters, dimensions, materials, and reflectors, are used to develop the MCNP inputs files reproduced in Appendix C.

Table 5-1-1. Modeled Facility and Equipment Dimensions for All Conditions

\begin{tabular}{|c|c|}
\hline Containers & Dimensions \\
\hline Glovebox & $\begin{array}{l}426.7 \mathrm{~cm} \times 198.1 \mathrm{~cm} \times 106.7 \mathrm{~cm}(14 \mathrm{ft} \times 6.5 \mathrm{ft} \times 3.5 \mathrm{ft} \text { or } 168 \\
\text { in. } \times 78 \mathrm{in} \times 42 \mathrm{in} \text {.), seismically qualified }\end{array}$ \\
\hline Precipitator Tanks & $\begin{array}{l}\mathrm{TK}-001 \mathrm{~A} / \mathrm{B} / \mathrm{C}, 16 \mathrm{~cm}(6.3 \mathrm{in} .) \text { dia. } \times 91.4 \mathrm{~cm}(36 \mathrm{in} .) \mathrm{T} / \mathrm{T}, 20.1 \\
\mathrm{~L}\end{array}$ \\
\hline Phase Separator Tank & $\begin{array}{l}\text { TK-004, } \quad 16 \mathrm{~cm}(6.3 \mathrm{in} .) \text { dia. } \times 91.4 \mathrm{~cm}(36 \mathrm{in} .) \mathrm{T} / \mathrm{T}, 20.1 \\
\mathrm{~L}\end{array}$ \\
\hline Vacuum Trap Tank & $\begin{array}{l}\text { TK-006, } 16 \mathrm{~cm}(6.3 \mathrm{in} .) \text { dia. } \times 55.9 \mathrm{~cm}(22 \mathrm{in} .) \mathrm{T} / \mathrm{T}, 11.2 \\
\mathrm{~L}\end{array}$ \\
\hline Vacuum Catch Tank & $16 \mathrm{~cm}(6.3$ in. $)$ dia. $\times 30.5 \mathrm{~cm}(12 \mathrm{in}.) \mathrm{T} / \mathrm{T}, 5.6 \mathrm{~L}$ \\
\hline Vacuum Filter Basin & $44.5 \mathrm{~cm}(17.5 \mathrm{in}$.$) dia. \times 5.3 \mathrm{~cm}(2.1 \mathrm{in}$.$) deep$ \\
\hline Drying Filter & $\begin{array}{l}\text { FL-001, } 44.5 \mathrm{~cm}(17.5 \mathrm{in} .) \text { dia. } x \sim 0.5 \mathrm{~cm} \mathrm{(3/16} \text { in.) made } \\
\text { of thick, dry plastic }\end{array}$ \\
\hline Polishing Filter & $\begin{array}{l}\text { FL- } 002 \mathrm{~A} / \mathrm{B}, 15.2 \mathrm{~cm}(6 \mathrm{in}) \mathrm{dia} . \times 39.4 \mathrm{~cm}(15.5 \mathrm{in})(1 \\
\text { operating, } 1 \text { standby) }\end{array}$ \\
\hline Drip Pan & $\begin{array}{l}30.5 \mathrm{~cm} \times 45.7 \mathrm{~cm} \times 5.1 \mathrm{~cm}(1 \mathrm{ft} \times 1-1 / 2 \mathrm{ft} \times 2 \text { in. or } 12 \text { in. } x \\
18 \text { in. } \times 2.1 \text { in. })\end{array}$ \\
\hline Hot Plate Boat & $27.9 \mathrm{~cm} \times 12.7 \mathrm{~cm} \times 6.4 \mathrm{~cm}(11$ in. $\times 5$ in. $\times 2.5 \mathrm{in}),. 2.3 \mathrm{~L}$ \\
\hline Boat - - - & $27.9 \mathrm{~cm} \times 12.7 \mathrm{~cm} \times 6.4 \mathrm{~cm}(11$ in. $\times 5$ in. $\times 2.5$ in. $), 2.3 \mathrm{~L}$ \\
\hline Boat at Boat Dock & $27.9 \mathrm{~cm} \times 12.7 \mathrm{~cm} \times 6.4 \mathrm{~cm}(11$ in $\times 5$ in $\times 2.5$ in. $), 2.3 \mathrm{~L}$, \\
\hline Sweeps Can & $0.5 \mathrm{~L}$ (geometry: $\mathrm{h}=\mathrm{d}=8.6 \mathrm{~cm}$ ) \\
\hline Trash Bag & $\begin{array}{l}0.13 \mathrm{~cm}(1 / 8 \text { in.) } \mathrm{Pu} \text { holdup on floor and } 2.54 \mathrm{~cm}(1 \mathrm{in} .) \text { of } \\
\text { water around containers conservatively bound } \mathrm{Pu} \text { and plastic } \\
\text { content }\end{array}$ \\
\hline Transfer Pump & P-001, $\quad 17 \mathrm{~cm}(6.7$ in. $)$ dia. $\times 20.3 \mathrm{~cm}(8 \mathrm{in}$.$) wide$ \\
\hline Sample Bottle & $\mathrm{Up}$ to $50 \mathrm{~mL}$ \\
\hline HEPA & $\begin{array}{l}2.54 \mathrm{~cm} \text { ( } 1 \text { in.) of water around containers conservatively } \\
\text { bounds }\end{array}$ \\
\hline
\end{tabular}


The dimensions of the normal case are those used for the base and contingency cases. Comparing Tables 2-1 and 5-1-1 shows that the glovebox is modeled at its actual size while the tanks and pump are conservatively modeled. The six tanks are modeled at a diameter of $6.3 \mathrm{in}$., which is larger than the actual 6.186 in. maximum inside diameter of the glass tank. The volume of the tank was modeled at $20.1 \mathrm{~L}$, an increase over the nominal tank volume of $20.0 \mathrm{~L}$ and the tank height was adjusted to fit the conservative diameter and volume. The shorter, larger diameter is a more conservative model of the tank volume.

The pump is modeled as a 6 in. diameter cylinder 8 in. long. This volume is much greater than the pump volume. The odd shaped pump is fabricated of $3 / 4$-in. piping around a $4 \mathrm{in}$. diameter central cylinder about 4 in. long with one inch long cones on each end of the cylinder. The surge tank connected to the pump is 5.25 in. diameter and $10.5 \mathrm{in.} \mathrm{long.} \mathrm{Half} \mathrm{the} \mathrm{surge} \mathrm{tank}$ would have air and the other half fluid from the pump. The volume of the pump model covers both the pump and surge tank volume. The added diameter of the tanks and pump covers the affect of the piping in the glovebox for the normal case. The tanks are modeled spaced at least an inch closer than as-built as shown in Appendix F.

Table 5-1-2. Mixture Density and Material Weight Fraction for Normal Operation Condition

\begin{tabular}{|l|l|l|l|l|r|}
\hline \multicolumn{1}{|c|}{ Containers } & \multicolumn{1}{|c|}{$\rho_{\text {uix }}$} & $\begin{array}{c}\text { Wt. } \\
\text { Frac. of } \\
\text { H }\end{array}$ & $\begin{array}{c}\text { Wt. } \\
\text { Frac. of } \\
\text { O }\end{array}$ & $\begin{array}{c}\text { Wt. } \\
\text { Frac. of } \\
\text { Pu }\end{array}$ & H/X \\
\hline Glovebox (1/8" holdup) & 4.104800 & 0.019040 & 0.250110 & 0.730850 & 6.23 \\
\hline Precipitator Tanks & 1.047500 & 0.105800 & 0.846500 & 0.047700 & 530.00 \\
\hline Phase Separator Tank & 1.000001 & 0.111111 & 0.888888 & 0.000001 & $27,750.00$ \\
\hline Vacuum Trap Tank & 1.000001 & 0.111111 & 0.888888 & 0.000001 & $27,750.00$ \\
\hline Vacuum Catch Tank & 1.000001 & 0.111111 & 0.888888 & 0.000001 & $27,750.00$ \\
\hline Vacuum Filter Basin & 1.903890 & 0.055600 & 0.444400 & 0.500000 & 27.00 \\
\hline Drying Filter & 1.000000 & 0.111111 & 0.888889 & 0.000000 & $\infty$ \\
\hline Polishing Filter & 1.000000 & 0.111111 & 0.888889 & 0.000000 & $\infty$ \\
\hline Drip Pan & 1.000000 & 0.111111 & 0.888889 & 0.000000 & $\infty$ \\
\hline Hot Plate Boat & 1.758500 & 0.060600 & 0.485100 & 0.454300 & 32.00 \\
\hline Furnace Boat & 1.758500 & 0.060600 & 0.485100 & 0.454300 & 32.00 \\
\hline Storage Boat Rack & 1.758500 & 0.060600 & 0.485100 & 0.454300 & 32.00 \\
\hline Sweeps Can & 3.848640 & 0.024500 & 0.196000 & 0.779500 & 7.50 \\
\hline Trash Bag & No Pu (floor holdup bounding conservatism) & $\infty$ \\
\hline Transfer Pump & 1.000000 & 0.111111 & 0.888889 & 0.000000 & $\infty$ \\
\hline HEPA & 1 in. water at roof conservatively bounds HEPA Pu content \\
\hline
\end{tabular}


Table 5-1-3. Reflector Material Contents for Normal Operation Condition

\begin{tabular}{|l|l|}
\hline \multicolumn{1}{|c|}{ Containers } & \\
\hline Glovebox & N/A \\
\hline Precipitator Tanks & N/A \\
\hline Phase Separator Tank & N/A \\
\hline Vacuum Trap Tank & N/A \\
\hline Vacuum Catch Tank & N/A \\
\hline Vacuum Filter Basin & N/A \\
\hline Drying Filter & N/A \\
\hline Polishing Filter & Filled with water \\
\hline Drip Pan & Filled with water \\
\hline Hot Plate Boat & N/A \\
\hline Furnace Boat & \\
\hline Storage Boat Rack & \\
\hline Sweeps Can & N/A \\
\hline Trash Bag & N/A \\
\hline Transfer Pump & N/A \\
\hline HEPA & lin. of water at top of glovebox conservatively bounds \\
\hline
\end{tabular}

The normal case includes six batches of $2.5 \mathrm{~kg}$ Pu material: one in the precipitation tanks, one in the basin and another in the adjacent boat, one in a boat on the hotplate, and one in each of the two boats sitting at the boat dock. An $1 / 8 \mathrm{in}$. of $3 \mathrm{~g} \mathrm{Pu} / \mathrm{cm}^{3}$ as plutonium oxide is modeled on the entire glovebox floor. The calculational model of the glovebox and components uses compositions from Section 2 and the tables above. The $k_{\text {efl }}$ for this case is $0.7900 \pm 0.0005$ (case nca). Reactivity of various components in the glovebox is provided in Appendix $G$.

\subsection{BASE CASES}

\subsubsection{PRIMARY BASE CASE}

The base case includes the normal as well as the abnormal but anticipated process conditions. The controlled parameters specified in Table 1-1, Summary of Base Case Limits, are used to model each process component as shown in Table 5-2-1 through Table 5-2-3. Two dimensional plots of the base case model having material numbers printed out for each component are shown in Appendix E. Figures E-3 to $\mathrm{E}-7$ are the $\mathrm{Y}-\mathrm{Z}$ side view plots $\mathrm{X}$ distance along the length of the glovebox. Figures $E-8$ to $E-10$ are the $X-Z$ front views plots $Y$ distance along the depth of the glovebox. Figures E-11 to E-15 are the X-Y top view plots $Z$ distance along the height of the glovebox. The numbers on the figures designate the material as explained in the table at the beginning of Appendix E. 
The precipitator tanks are modeled with $100 \mathrm{~g} P u / L$ plutonium nitrate solution that bounds the actual operation. The $100 \mathrm{~g} \mathrm{Pu} / \mathrm{L}$ is conservative relative to the normal design operating conditions of $50 \mathrm{~g} \mathrm{Pu} / \mathrm{L}$. Figure III.A.4(100)-1 in ARH-600 (Carter 1968) shows that the most reactive concentration of plutonium nitrate over the range of 0 to $450 \mathrm{~g} \mathrm{Pu} / \mathrm{L}$ (maximum credible plutonium nitrate solution at PFP) in a cylinder is $250 \mathrm{~g} \mathrm{Pu} / \mathrm{L}$. This concentration of plutonium nitrate solution will be used as a contingency in Section 5.3.1. The $450 \mathrm{~g} \mathrm{Pu} / \mathrm{L}$ is an upper bound on plutonium nitrate solution because PUREX and PFP had that as the limit on plutonium solution concentration. Any solutions above that concentration would have been diluted to be within that allowable.

The bottom of the precipitation tanks have 3 in. long conical transition fittings between the bottom of the glass cylindrical tank and the process piping. Two flanges are used to make a seal at this transition. Because the flanges and fittings are stainless steel, the bottom 3 to $4 \mathrm{in}$. are not visible from the side. Operators may not know if there are solids in the bottom of the tanks. To allow operations without inspecting the bottom $4 \mathrm{in}$. of the tanks, the base case includes solids in the bottom of the tanks. The base case could have used $5 \mathrm{in}$. of low density plutonium oxide. However, the model used covers the upset condition of precipitate from a full $20 \mathrm{~L}$ tank filled with $450 \mathrm{~g} \mathrm{Pu} / \mathrm{L}$ plutonium nitrate solution at a highly conservative density of $3 \mathrm{~g} \mathrm{Pu} / \mathrm{cm}^{3}$. Because $450 \mathrm{~g} \mathrm{Pu} / \mathrm{L}$ is the maximum plutonium concentration allowed at PUREX and PFP, this is the maximum plutonium possible for a filled tank. At $3 \mathrm{~g} \mathrm{Pu} / \mathrm{cm}^{3}$, the $9 \mathrm{~kg}$ of plutonium occupies 6 in. of the 6.3 in. diameter glass tank. Using this high density solids and full diameter tank, the tank model is highly conservative and would accommodate any plutonium solution and precipitate without exceeding double contingency limits. The normal 600 grams to be precipitated in a precipitation tank would occupy 4 in. at an expected $0.3 \mathrm{~g} \mathrm{Pu} / \mathrm{cm}^{3}$. At $3 \mathrm{~g}$ $\mathrm{Pu} / \mathrm{cm}^{3}$, the 600 grams would only occupy 0.39 in. Using 6 in. of $3 \mathrm{~g} \mathrm{Pu} / \mathrm{cm}^{3}$ is conservative.

The plutonium in the solution is precipitated by addition of magnesium hydroxide and agitated to promote a complete chemical reaction. To analyze the tanks loaded with plutonium precipitate, $15.2 \mathrm{~cm}\left(6 \mathrm{in}\right.$.) of plutonium at $3 \mathrm{~g} \mathrm{Pu} / \mathrm{cm}^{3}$ as $\mathrm{PuO}_{2}$ is modeled at the bottom of the three precipitator tanks with $100 \mathrm{~g} / \mathrm{L}$ plutonium nitrate solution filling up the rest of the tank. For the base case, all other tanks (phase separator, vacuum trap, and vacuum catch tanks) are also filled with a concentration of $\mathrm{Pu}\left(\mathrm{NO}_{3}\right)_{4}$ solution of $1 \mathrm{~g} \mathrm{Pu} / \mathrm{L}$, bounding the $10^{-3} \mathrm{~g} \mathrm{Pu} / \mathrm{L}$ expected concentration.

The model does not include any magnesium even though it may be present as hydroxide, nitride, or oxide. Magnesium has a low absorption cross section, but not as low as oxygen. Hydrogen is a more effective moderator. Figure 46 in LA-10860-MS shows that for useful concentrations of fissionable material, water is a more reactive material to mix with fissionable material than beryllium, heavy water, or carbon. The fissionable material is modeled with water filling out the solution, precipitate, or filter cake rather than including any magnesium that would displace water.

The base case for the vacuum filter basin has $2.75 \mathrm{~kg}$ plutonium containing $50 \mathrm{wt} \%$ moisture as a layer above the perforated plate that holds the filter and $1.77 \mathrm{~kg}$ of plutonium below the filter plate as $1 \mathrm{in}$. of $450 \mathrm{~g} \mathrm{Pu} / \mathrm{L}$ solution (highest possible concentration at PFP). 
Any plutonium residue dripping from the filters on the drying rack into the drip pan is modeled by the $1 / 8$ in. thick layer of $3 \mathrm{~g} \mathrm{Pu} / \mathrm{cm}^{3}$ as $\mathrm{PuO}_{2}$ holdup on glovebox floor. The polishing filters are modeled full of $1 \mathrm{~g} \mathrm{Pu} / \mathrm{L}$ solution.

Trash bags are conservatively bounded by the $1 / 8 \mathrm{in}$. thick layer of $3 \mathrm{~g} \mathrm{Pu} / \mathrm{cm}^{3}$ as $\mathrm{PuO}_{2}$ on the floor and the water reflector around containers and the glovebox. Table 5-2-2 lists each item's mixture densities and material weight fractions input to MCNP for the base case.

The base case does not include the unlikely event of an overflow along the vacuum system or solution misrouted. This condition is evaluated as a contingency in Section 5.3.1 where the phase separator tank $(20 \mathrm{~L})$, vacuum trap tank $(11 \mathrm{~L})$, vacuum catch tank $(5.6 \mathrm{~L})$, and polishing filters are all modeled as filled with $250 \mathrm{~g} \mathrm{Pu} / \mathrm{L}$ solution.

No limit on holdup depth is included in the limits because for this system, an $1 / 8$ in. layer of plutonium on the entire glovebox floor is equal to $43.37 \mathrm{~kg}$ of plutonium, an incredible amount, and because cleanup of spills is required.

The base case models a boat with $2.75 \mathrm{~kg}$ plutonium so that double contingency is demonstrated for a small error $(<0.25 \mathrm{~kg} \mathrm{Pu})$ in mass. In addition, a $2.3 \mathrm{~L}$ boat containing 2.75 $\mathrm{kg}$ of plutonium at $\mathrm{Pu}$ oxide density mixed with water is placed under a precipitation tank, an abnormal but anticipated event. Trash bags are conservatively bounded by the $1 / 8 \mathrm{in}$. thick layer of $3 \mathrm{~g} \mathrm{Pu} / \mathrm{cm}^{3}$ as $\mathrm{PuO}_{2}$ on the floor. Table 5-2-2 lists each item's mixture densities and material weight fractions input to MCNP for the base cases.

The base case models five boats with $2.75 \mathrm{~kg}$ of plutonium in each boat. Four boats are located at the four normal stations for boats: two boats in the boat dock; one boat on the hot plate; and one boat adjacent to the vacuum filter basin. In this base case model, both the basin and adjacent boats have $2.75 \mathrm{~kg} \mathrm{Pu}$. The basin and associated boat are limited to $2.75 \mathrm{~kg}$ each. A fifth boat is placed under the precipitation tanks to cover the anticipated upset condition of a boat placed on the floor of the solution process area of the glovebox. It also covers the case of one boat stored in the straight segment of Glovebox 5 connection to conveyor HC-3 from Glovebox 3 .

Because of the tight spacing of the boat dock, drip pan, and filter drying line supports, and hot plate cover supports, a third boat at the boat dock is not anticipated and that case is treated as a contingency in Section 5.3.

The reflection that a scale, hot plate, struts, piping, and other equipment may contribute is bounded by water surrounding the glovebox. The HEPA filter, with up to $10 \mathrm{~g} \mathrm{Pu} / \mathrm{ft}^{3}$, is bounded by the $1 / 8$ in. of plutonium holdup on the glovebox floor and by $1 \mathrm{in}$. of water at the level of the roof of the glovebox. To simulate operators standing around the glovebox and other potential neutron reflection materials, 12 in. of water surrounds the sides of the glovebox. To account for operators reaching under the glovebox, 6 in. of water is modeled below the glovebox. And $1 \mathrm{in}$. of water above the glovebox models nominal room reflection. Table 5-2-3 has other details of reflector modeling. The combination of normal conditions allowed by limits and anticipated abnormal conditions are used to evaluate the criticality safety of normal operations in the 
glovebox as the base case. The calculated $k_{\text {eff }}$ for this base case, bc, is $0.8825 \pm 0.0005$. Sensitivity of this $k_{\text {eff }}$ to various components in the glovebox is presented in Appendix $G$.

Table 5-2-1. Fissionable \& Moderator Material Contents for Base Case

\begin{tabular}{|c|c|}
\hline Containers & Contents \\
\hline Glovebox & $\begin{array}{l}1 / 8 \text { in. thick layer of } 3 \mathrm{~g} \mathrm{Pu} / \mathrm{cm}^{3} \text { as } \mathrm{PuO}_{2} \text { on floor modeling } \\
\text { glovebox holdup. It is under the boats and other equipment. }\end{array}$ \\
\hline Precipitator Tanks & $\begin{array}{l}\text { (a) The tank contents are simulated by } 100 \mathrm{~g} \mathrm{Pu} / \mathrm{L} \text { solution of } \\
\text { plutonium nitrate mixed with water, plus } \\
\text { (b) } 6 \text { in. of } \mathrm{Pu} \text { solids }\left(3 \mathrm{~g} \mathrm{Pu} / \mathrm{cm}^{3} \text { as } \mathrm{PuO}_{2}\right) \text { at bottom of the } \\
\text { three precipitation tanks }\end{array}$ \\
\hline Phase Separator Tank & $\begin{array}{l}\text { The tank contents are simulated by } 1 \mathrm{~g} \mathrm{Pu} / \mathrm{L} \text { solution of } \\
\text { plutonium nitrate mixed with water and filling the } 20.1 \mathrm{~L} \text { tank } \\
\text { completely }\end{array}$ \\
\hline Vacuum Trap Tank & $\begin{array}{l}\text { The tank contents are simulated by } 1 \mathrm{~g} \mathrm{Pu} / \mathrm{L} \text { solution of } \\
\text { plutonium nitrate mixed with water and filling the } 11.2 \mathrm{~L} \text { tank } \\
\text { completely. }\end{array}$ \\
\hline Vacuum Catch Tank & $\begin{array}{l}\text { The tank contents are simulated by } 1 \mathrm{~g} \mathrm{Pu} / \mathrm{L} \text { solution of } \\
\text { plutonium nitrate mixed with water and filling the } 5.6 \mathrm{~L} \text { tank } \\
\text { completely }\end{array}$ \\
\hline Vacuum Filter Basin & $\begin{array}{l}\text { (a) } 2.75 \mathrm{~kg} \text { Pu in } 50 \mathrm{wt} \% \text { moisture precipitate cake on filter } \\
\text { with max. of } 2.1 \mathrm{in} \text {. accumulation depth allowed above } \\
\text { the perforated filter support plate, plus } \\
\text { (b) } 1 \text { in. of } 450 \mathrm{~g} \mathrm{Pu} / \mathrm{L} \text { solution below perforated plate }\end{array}$ \\
\hline Drying Filter & Bounded by $1 / 8$ in. holdup on glovebox floor \\
\hline Polishing Filter & $1 \mathrm{~g} \mathrm{Pu} / \mathrm{L}$ solution \\
\hline Drip Pan & $\begin{array}{l}\text { Simulated by } 1 \mathrm{~g} \mathrm{Pu} / \mathrm{L} \text { solution of plutonium nitrate mixed } \\
\text { with water and filling the pan }\end{array}$ \\
\hline Boat on Hot Plate & $2.75 \mathrm{~kg}$ Pu metal mixed with water and filling a $2.3 \mathrm{~L}$ boat. \\
\hline Boat & $2.75 \mathrm{~kg}$ Pu metal mixed with water and filling a $2.3 \mathrm{~L}$ boat. \\
\hline Boat Dock & $\begin{array}{l}2.75 \mathrm{~kg} \text { Pu metal mixed with water and filling two } 2.3 \mathrm{~L} \\
\text { boats. }\end{array}$ \\
\hline $\begin{array}{l}\text { Boat in tank section of } \\
\text { glovebox }\end{array}$ & $\begin{array}{l}2.75 \mathrm{~kg} \text { Pu metal mixed with water and filling a } 2.3 \mathrm{~L} \text { boat } \\
\text { located under center precipitation tank. }\end{array}$ \\
\hline Sweeps Can & $\begin{array}{l}1.5 \mathrm{~kg} \text { at } 3 \mathrm{~g} \mathrm{Pu} / \mathrm{cm}^{3} \text { as Pu in water at an } \mathrm{H} / \mathrm{X} \text { of } 7.5 \text {, which } \\
\text { bounds an } \mathrm{H} / \mathrm{X} \text { of } 20 \text { limit for the sweeps can Pu as oxide. }\end{array}$ \\
\hline Trash Bag & $\begin{array}{l}1 / 8 \text { in. thick layer of } 3 \mathrm{~g} \mathrm{Pu} / \mathrm{cm}^{3} \text { as } \mathrm{PuO}_{2} \text { on floor } \\
\text { conservatively bounds trash bag }\end{array}$ \\
\hline Transfer Pump & $\begin{array}{l}1 / 8 \text { in. thick layer of } 3 \mathrm{~g} \mathrm{Pu} / \mathrm{cm}^{3} \text { as } \mathrm{PuO}_{2} \text { on floor } \\
\text { conservatively bounds transfer pump }\end{array}$ \\
\hline Sample Bottles & Excess tanks diameter bounds sample bottles \\
\hline HEPA & $\begin{array}{l}\text { Floor holdup plutonium and } 1 \text { in. of water at roof } \\
\text { conservatively bounds mass and reflection of filter }\end{array}$ \\
\hline
\end{tabular}


Table 5-2-2. Mixture Density and Material Weight Fraction for Base Case

\begin{tabular}{|l|l|l|l|r|r|}
\hline \multicolumn{1}{|c|}{ Containers } & \multicolumn{1}{|c|}{$\rho_{\text {mix }}$} & $\begin{array}{c}\text { Wt. } \\
\text { Frac.* of } \\
\mathbf{H}\end{array}$ & $\begin{array}{c}\text { Wt. } \\
\text { Frac. of } \\
\mathbf{O}\end{array}$ & $\begin{array}{c}\text { Wt. } \\
\text { Frac. of } \\
\text { Pu }\end{array}$ & H/X \\
\hline Glovebox holdup & 4.101430 & 0.019040 & 0.250110 & 0.730850 & 6.23 \\
\hline Precipitator Tanks (a) & 1.158000 & 0.092000 & 0.802000 & 0.086000 & 530.00 \\
\hline Precipitator Tanks (b) & 4.101430 & 0.019040 & 0.250110 & 0.730850 & 6.23 \\
\hline Phase Separator Tank & 1.001000 & 0.111000 & 0.888000 & 0.001000 & 26517.00 \\
\hline Vacuum Trap Tank & 1.001000 & 0.111000 & 0.888000 & 0.001000 & 26517.00 \\
\hline Vacuum Catch Tank & 1.001000 & 0.111000 & 0.888000 & 0.001000 & 26517.00 \\
\hline Vacuum Filter Basin (a) & 1.903890 & 0.055600 & 0.444400 & 0.500000 & 27.00 \\
\hline Vacuum Filter Basin (b) & 1.427280 & 0.076079 & 0.608635 & 0.315286 & 57.00 \\
\hline Drying Filter & Bounded By $1 / 8$ of Gloveboxb holdup & \\
\hline Polishing Filter & 1.001000 & 0.111000 & 0.888000 & 0.001000 & 26517.00 \\
\hline Drip Pan & 1.001000 & 0.111000 & 0.888000 & 0.001000 & 26517.00 \\
\hline Hot Plate Boat & 2.263000 & 0.043000 & 0.418000 & 0.539000 & 19.00 \\
\hline Boat & 2.263000 & 0.043000 & 0.418000 & 0.539000 & 19.00 \\
\hline Boat Dock & 2.263000 & 0.043000 & 0.418000 & 0.539000 & 19.00 \\
\hline Transition Boat & 2.263000 & 0.043000 & 0.418000 & 0.539000 & 19.00 \\
\hline Sweeps Can & 3.848640 & 0.024500 & 0.196000 & 0.779500 & 7.50 \\
\hline Trash Bags & Bounded by $1 / 8$ in. of glovebox holdup & \\
\hline Transfer Pump & Bounded by $1 / 8$ in. of glovebox holdup \\
\hline Sample Bottles & Excess tanks diameter bounds sample bottles & \\
\hline HEPA & Bounded by Pu holdup and 1 in. water at roof & \\
\hline
\end{tabular}

* Wt. Frac. of $\mathrm{N}$ is 0.02

Table 5-2-3. Reflector Material Contents for Base Case

\begin{tabular}{|c|c|}
\hline Containers & Contents \\
\hline Glovebox & $\begin{array}{l}12 \text { in. of water around sides accounts for operators; } \\
6 \text { in. of water below accounts for operator reaching under } \\
\text { glovebox; } \\
1 \text { in. of water above models nominal room reflection. }\end{array}$ \\
\hline Precipitator Tank & \multirow{4}{*}{$\begin{array}{l}1 \text { in. of water reflector around a } 6 \text { in. length of each tank } \\
\text { accounts for operator hands, rags, piping, equipment and trash }\end{array}$} \\
\hline Phase Separator Tank & \\
\hline Vacuum Trap Tank & \\
\hline Vacuum Catch Tank & \\
\hline Vacuum Filter Basin & \multirow{3}{*}{$\begin{array}{l}1 \text { in. of water reflector around each filter accounts for operator } \\
\text { hands, rags, piping, equipment and trash. }\end{array}$} \\
\hline Drying Filter & \\
\hline Polishing Filter & \\
\hline Drip Pan & $\begin{array}{l}\text { Bounded by } 6 \text { in. of water under glovebox and } 5.08 \mathrm{~cm}(2 \mathrm{in} \text {.) } \\
\text { of water filling the drip pan }\end{array}$ \\
\hline
\end{tabular}


HNF-6537 REV. 0

\begin{tabular}{|l|l|}
\hline \multicolumn{1}{|c|}{ Containers } & \multicolumn{1}{c|}{ Contents } \\
\hline Boat by vacuum filter & $\begin{array}{l}1 \text { in. of water reflector around each boat accounts for operator } \\
\text { hands, rags, piping, equipment and trash }\end{array}$ \\
\hline Boat on Hot Plate & $\begin{array}{l}1 \text { in. of water reflector around can accounts for operator hands, } \\
\text { rags, piping, equipment and trash }\end{array}$ \\
\hline Storage Boat Dock & 1 in. of water around containers conservatively bounds \\
\hline Sweeps Can & Bounded by water around glovebox \\
\hline Trash Bag & Excess tanks diameter bounds sample bottles \\
\hline Transfer Pump & Pu holdup and 1 in. of water at roof conservatively bounds \\
\hline Sample Bottles &
\end{tabular}

\subsubsection{ALTERNATE BASE CASE}

Only four boats containing fissionable material are allowed in Glovebox 3. Only one boat is allowed to be stored or left unattended at the basin and at the hot plate and only two at the boat dock. Since one boat is allowed to be in transit without spacing, the alternate base case shows that the $\mathrm{k}_{\text {eff }}$ for three boats is within allowables. Since the space at the hot plate end of the glovebox is crowded with equipment and structure, a boat in transit is allowed to be close to the basin containing a $2.75 \mathrm{~kg}$ batch of plutonium in the basin and one batch in an adjacent boat or to the boat dock with two boats each containing a batch. To preclude having three batches normally within $25.4 \mathrm{~cm}$ (10 in.) of each other, the boat in transit is not allowed to be stored at the basin, hot plate, or boat dock. This restriction and the restriction that only four boats are allowed in Glovebox 3 makes an accidental grouping of four boats unlikely.

No specific cases were run for the alternate base case of three batches of $2.75 \mathrm{~kg}$ of plutonium grouped together. Six contingency cases will be used to show that the three batch aggregation is acceptable. Case cc3 listed in Table 5-3-1 shows that two adjacent boats with one double batched has an acceptable $k_{\text {eff }}$ of $0.8860 \pm 0.0005$. Case cc 4 stacks a third boat on top of two below violating stacking, but it bounds three adjacent boats. Table 5-3-1 lists the $\mathrm{k}_{\text {eff }}$ for this case as an acceptable $0.8871 \pm 0.0006$. The case $\operatorname{cc} 8$ double batches the vacuum filter basin with $5.5 \mathrm{~kg}$ of plutonium as described in Section 5.3 .8 of this CSER. A third batch is in the adjacent boat. This three batch assembly has a $k_{\text {eff }}$ of $0.8741 \pm 0.0005$. Also described in Section 5.3 .8 is case ccs that filled the $2.1 \mathrm{in}$. deep upper portion of the basin with $14.9 \mathrm{~kg}$ at $2 \mathrm{~g} \mathrm{Pu} / \mathrm{cm}^{3}$ and had a boat adjacent to the basin. This case has 6 batches of $2.75 \mathrm{~kg}$ of plutonium. Table 5-3-1 list the $\mathrm{k}_{\mathrm{eff}}$ as 0.9352 . If four boats are arranged as a wall between the boat dock and the corner of the glovebox against the side of the glovebox as shown in Figure E-16, a $\mathrm{k}_{\text {eff }}$ of $0.8921 \pm 0.0005$ results. In this case $\mathrm{cc} 10$, the boats are head to head and stacked two high. Each boat has 2.75 $\mathrm{kg}$ plutonium in water filling the boat volume. The two boats on the top are covered by an inch of water. The boats at the boat dock, hot plate, and basin, are modeled as water since having eight batches is not credible. The batch in the tanks and in the vacuum basin were retained. The eighth inch of $3 \mathrm{~g} \mathrm{Pu} / \mathrm{cm}^{3}$ on the glovebox floor is also retained in this model. A sixth case, ccl03, has the same arrangement of the glovebox as case ccs except the four boats are arranged in a two by two array with the long sides adjacent. This case is described in Section 5.3.3. The $\mathrm{k}_{\mathrm{eff}}$ is $0.9312 \pm 0.0005$. This case, cc103, bounds four boats arranged in a plane. 
Glovebox 3 has numerous containers that are allowed to move about the glovebox. The contingency case $\mathrm{cwcc} 7$ is being used to show that the worst case grouping of these containers is within allowables. The worst case arrangement has all the containers grouped around the vacuum filter basin because the basin adds the most volume to the model. None of the containers are stacked, that would violate a limit. This model explicitly incorporates the mass and volume of: (1) the vacuum filter basin with a $2.75 \mathrm{~kg}$ batch of plutonium; (2) two boats with a batch each (actually three boats for the contingency case cwcc7); (3) the $1 \frac{1}{2} \mathrm{~L}$ sweeps can with $1.5 \mathrm{~kg}$ of plutonium; (4) the $1 \mathrm{~L}$ leak detection bottle filled with $250 \mathrm{~g} \mathrm{Pu} / \mathrm{L}$ feed; (5) three 250 $\mathrm{mL} \mathrm{pH}$ sample containers filled with $250 \mathrm{~g} \mathrm{Pu} / \mathrm{L}$ feed. The twelve sample bottles of up to $50 \mathrm{~mL}$ each filled with $3 \mathrm{~g} \mathrm{Pu} / \mathrm{L}$ filtrate are considered bounded by the extra mass and volume in the vacuum filter basin modeled with a larger than the design diameter and the reflection modeled around model and around the glovebox. The material in the non-boat containers are about 3 in. tall, except the $1 \mathrm{~L}$ leak detection bottle. It too is modeled as 3.1 in. tall to be as close to the rest of the fissionable material as possible. The material in the basin is modeled in the upper portion above the perforated plate with a depth of 2.1 in. which is consistent with the height to which boats can hold material. The model geometry and materials are described in Section 5.3.4. The $\mathrm{k}_{\text {eff }}$ for the case $\mathrm{cwcc} 7$ is $0.8864 \pm 0.0005$. This contingency case shows that an aggregation of four batches and the containers that can move about the glovebox are within the allowable limit of 0.942

\subsection{CONTINGENCIES}

A contingency is defined as an unlikely event, process upset condition, or natural phenomena. The CSER shows in the contingency analysis that a contingent event in singular occurrence will not result in exceeding the allowable $k_{\text {eff }}$ for the critical system being analyzed and that the Double Contingency Principle is met. The Double Contingency Principle requires that two independent, unlikely occurrences are necessary to exceed the allowable $k_{\text {eff }}$ or other specified limit for the critical system being analyzed before a criticality is possible. Table 5-3-1 lists the postulated unlikely, independent, non-concurrent, off-normal events (contingencies) and the analysis results. Each event is assumed to occur upon adding a contingency condition to the base case (bc) as configured in the previous section.

Table 5-3-1. Contingencies for Glovebox 3

\begin{tabular}{|c|c|c|c|}
\hline Case & Description & $\mathrm{k}_{\mathrm{efr}}$ & $\begin{array}{l}\text { One } \\
\text { Sigma }\end{array}$ \\
\hline $\mathrm{ccl}$ & $\begin{array}{l}250 \mathrm{~g} / \mathrm{L} \text { Pu nitrate in precipitation tanks with } 15.2 \mathrm{~cm} \\
\text { of Pu oxide solids in tank bottom at } 3 \mathrm{~g} \mathrm{Pu} / \mathrm{cm}^{3}\end{array}$ & 0.8884 & 0.0005 \\
\hline $\operatorname{cc} 2 \mathrm{c}$ & $\begin{array}{l}\text { Vacuum tanks/phase separator tank/precipitator tanks } \\
\text { filled with } 250 \mathrm{~g} / \mathrm{L}\end{array}$ & 0.8932 & 0.0005 \\
\hline $\operatorname{cc} 3$ & One over batched boat in boat dock & 0.8860 & 0.0005 \\
\hline $\mathrm{cc} 4$ & Third boat stacked on top of two boats in boat dock & 0.8871 & 0.0006 \\
\hline $\operatorname{cc} 103$ & $2 \times 2$ boat array in glovebox corner & 0.9312 & 0.0005 \\
\hline $\operatorname{cc} 5$ & $\begin{array}{l}\text { Seismic event with broken tanks and sprinkler water } \\
\text { to } 3.25 \text { in. depth on floor of glovebox. }\end{array}$ & 0.9359 & 0.0005 \\
\hline
\end{tabular}


HNF-6537 REV. 0

\begin{tabular}{|c|c|c|c|}
\hline Case & Description ${ }^{*}$ & $\mathbf{k}_{\text {eff }}$ & $\begin{array}{l}\text { One } \\
\text { Sigma }\end{array}$ \\
\hline $\operatorname{ccl} 121$ & $\begin{array}{l}\text { Interspersed moderation at full water density without } \\
\text { glass tanks breaking. }\end{array}$ & 0.9410 & 0.0014 \\
\hline cwcc7 & Aggregate of containers & 0.8864 & 0.0005 \\
\hline $\operatorname{cc7}$ & Conservative $4.5 \mathrm{~kg} \mathrm{BTC}$ against side of glovebox & 0.9105 & $\overline{0.0006}$ \\
\hline $\operatorname{cc} 8$ & $\begin{array}{l}\text { Double batched vacuum filter basin having } 5.5 \mathrm{~kg} \mathrm{Pu} \\
\text { as metal mixed with water filling upper basin }\end{array}$ & 0.8741 & 0.0005 \\
\hline $\operatorname{ncs} 2$ & Spacing between tanks reduced & 0.9207 & 0.0014 \\
\hline $\operatorname{ccs}$ & Upper vacuum filter basin filled with $2 \mathrm{~g} \mathrm{Pu} / \mathrm{cm}^{3} \mathrm{PuO}_{2}$ & 0.9352 & 0.0005 \\
\hline
\end{tabular}

* Each contingency model uses the base case bc with the changes described in this table.

Precipitate tanks were evaluated for the unlikely event of filling with the optimum reactivity, $250 \mathrm{~g} \mathrm{Pu} / \mathrm{L} \mathrm{Pu}\left(\mathrm{NO}_{3}\right)_{4}$ solution (cc1). Vacuum and phase separator tanks were evaluated for the unlikely occurrence of precipitate tank contents finding their way to these tanks $(\operatorname{cc} 2 \mathrm{c})$. One of the boats in the boat dock was double batched $(\operatorname{ccs} 3)$. A boat was stacked on top of two boats already at the boat dock (cc4). This case cc103 bounds an extra boat. A fissionable material container was brought up to the side of the glovebox (cc7) and the filter basin was double-batched with solids (cc8). Case ccs, a contingency case, and case ccs1 (an incredible case, see Section 5.3.8) show that the vacuum filter basin is a geometrically favorable container. The vacuum filter basin rim is 2.1 in. above the perforated plate that holds the filter. This basin is to hold the precipitate filtered out of the filtrate. There is a maximum of a one-inch high space below the perforated plate that can be filled with plutonium bearing precipitate or solution if not drawn off by the vacuum into the outlet pipe. The filter is conservatively left out of the vacuum filter basin in determining the depth of material in the vacuum filter basin. Case ccs fills only the upper portion ( $2.1 \mathrm{in}$.) of the basin with $2 \mathrm{~g} \mathrm{Pu} / \mathrm{cm}^{3}$ solid, where case ccs 1 fills both the upper and lower portions ( 1 in.) of the basin with the same material which is incredible, based on the amount of plutonium needed to fill the basin. Although not within allowables, case ccs 1 shows that even in the case of filling the basin with multiple batches of precipitate from the precipitation tanks, the basin remains subcritical. Case cc103 shows that four boats filled with plutonium oxide in water in a glovebox corner is within allowables. Case cwcc7 shows that over six batches and containers allowed to move about the govebox when clustered are within allowables. The basis and the details of those contingency scenarios are further illustrated in the following subsections. 


\subsubsection{Tank Cases}

The three precipitation tanks receive feed solution from the blend tanks in HA-227S. If the solution retrieved from $P R$ cans is not properly diluted and blended, and sampling fails, solutions of up to $450 \mathrm{~g} \mathrm{Pu} / \mathrm{L}$ could be received in the precipitation tanks in Glovebox 4.

As shown in Section 5.2.1 for the base case, over the range of 0 to $450 \mathrm{~g} \mathrm{Pu} / \mathrm{L}, 250 \mathrm{~g} \mathrm{Pu} / \mathrm{L}$ is the most reactive concentration of plutonium nitrate solution. To cover all possible off-normal events, contingency case $\mathrm{ccl}$ is modeled with the three precipitation tanks filled with $250 \mathrm{~g} \mathrm{Pu} / \mathrm{L}$ plutonium nitrate solution. Since each tank is normally loaded with $12 \mathrm{~L}$ of $50 \mathrm{~g} \mathrm{Pu} / \mathrm{L}$, this model covers both an out-of-procedure concentration and out-of-procedure volume of the transferred solution. The tanks are also modeled with six inches of $3 \mathrm{~g} \mathrm{Pu} / \mathrm{cm}^{3}$ at the bottom of the three precipitation tanks. Each tank has an amount of solids equal to that that could be precipitated from $20 \mathrm{~L}$ of $450 \mathrm{~g} \mathrm{Pu} / \mathrm{L}$ solution, $9 \mathrm{~kg}$. This is as much plutonium as can be transferred into the tank because of the maximum concentration of solutions allowed at PFP and the size of the tanks. Each tank has a maximum load of precipitate at an incredible density of $3 \mathrm{~g}$ $\mathrm{Pu} / \mathrm{cm}^{3}$ for the magnesium hydroxide process and the remaining $16.7 \mathrm{~L}$ volume with the most reactive plutonium nitrate solution, $250 \mathrm{~g} \mathrm{Pu} / \mathrm{L}$ for the possible range, 0 to $450 \mathrm{~g} \mathrm{Pu} / \mathrm{L}$. Each tank is modeled carrying a double worst case loading. The tanks are modeled one inch closer than design and, in one case, $2 \frac{1}{2}$ in. closer than installed (See Appendix F).

The model of the three precipitation tanks has reflections from one inch thick close fitting water coincident with the six inches of solids and full water reflection from the glovebox sides and bottom. The top gives one inch water reflection. The other tanks and containers have the base case loading.

This worst case model of the precipitation tanks has a $\mathrm{k}_{\mathrm{efr}}$ of $0.8885 \pm 0.0005$. Because this worst case loading is within allowables no limits are required for the precipitation tanks. However, the vacuum filter basin and boat loading have to be restricted. Limits are imposed on the concentration and mass of the feed solution. To limit the boat loading to $2.5 \mathrm{~kg}$ of plutonium, the mass per three tank batch is limited to $2.5 \mathrm{~kg}$ of plutonium. A concentration limit is also used to limit the mass to Glovebox 3 because the concentration of the feed is to be sampled and confirmed before transfer to Glovebox 3 . The $100 \mathrm{~g} \mathrm{Pu} / \mathrm{L}$ concentration limit is an arbitrary value, but it gives ample margin for the process design value of $50 \mathrm{~g} \mathrm{Pu} / \mathrm{L}$ and limits the full precipitation tanks to less than $6 \mathrm{~kg}$. Only a little more than a double batch of $5.5 \mathrm{k}_{\mathrm{eff}}$ for the basin and boats.

The phase separator tank, vacuum catch tank, and vacuum trap tank do not normally have liquids with more than $3 \mathrm{~g} \mathrm{Pu} / \mathrm{L}$. The phase separator tank receives the filtrate from the vacuum filter basin after the precipitation and filtering. Only when the precipitation is incomplete or not filtered will the significant amounts of plutonium be expected in the phase separator tank. Spills in Gloveboxes 3 and 4 can be vacuumed up into the vacuum catch tank as well as filtrate trapped in the vacuum trap tank and gravity drained to the vacuum catch tank. Significant quantities of filtrate are only expected in the vacuum trap tank if there is an over flow in the phase separator tank, or vacuum catch tank, the vacuum would pull the fluids to the vacuum catch tank. 
However, the vacuum trap tank is twice as large as the vacuum catch tank and half the volume of the phase separator tanks, so a small overflow can be accommodated. Only a gross break down of operating procedures could get significant accumulations into the vacuum trap tank.

Filling the vacuum trap tank so fluid is sucked into the eductor and out into the glovebox atmosphere and forming a plutonium mist is not considered credible. Fluid expelled from the eductor is expected to collect on surfaces and drip to the floor where it is in a safe configuration limited in depth by the criticality drain.

Although it is unlikely that the critically geometrically favorable 6.186 in. maximum diameter tanks in the vacuum system would receive concentrated plutonium nitrate solution, a model was run of the phase separator tank, the vacuum catch tank, and the vacuum trap tank filled with the most reactive concentration of plutonium nitrate solution, $250 \mathrm{~g} \mathrm{Pu} / \mathrm{L}$. Only solution is considered because although solids could get to these tanks, the solids can not be in the precipitation tanks, the filter basin, and in these three tanks either. The solids would be more reactive in the precipitation tanks, which are part of this model. The $k_{\text {eff }}$ for all six tanks containing feed solution $(\mathrm{cc} 2 \mathrm{c}$ ) is $0.8893 \pm 0.0005$. A small increase in reactivity from the three precipitation tanks case $\mathrm{ccl}$. Filling all tanks with the most reactive feed solution, with solids in the precipitation tanks, vacuum filter basin, and boats, and with the base case reflection is shown to be within the $\mathrm{k}_{\text {eff }}$ allowable limit of 0.942 for non-metal plutonium systems. Glovebox 3 is double contingent for introduction of and precipitation of plutonium solutions because the worst case precipitate and solution filling all tanks combined has a $\mathrm{k}_{\mathrm{eff}}$ less than that allowed.

\subsubsection{Over Batched Boat}

One boat is allowed adjacent to the vacuum filter basin, one on the hot plate, and two at the boat dock. One contingency is to put two batches of plutonium from the vacuum filter basin into a single boat, double batching it.

Case cc3 puts $5.5 \mathrm{~kg}$ into a single boat mixing plutonium at metal density with water resulting in a plutonium concentration of $2.44 \mathrm{~g} \mathrm{Pu} / \mathrm{cm}^{3}$ and an $\mathrm{H} / \mathrm{X}$ of 8.25 that fills one boat of $2.25 \mathrm{~L}$. This mixture in one boat adjacent to a 2.75 batched boat has a $\mathrm{k}_{\text {eff }}$ of $0.8860 \pm 0.0005$.

\subsubsection{Loss of Spacing Between Boats}

Case cc103 arranges four boats in a two by two array in a corner of the glovebox. The boats are arranged long side next to long side. By being in a corner, the array has full water reflection on three sides. The other three sides do not have close fitting water reflection, because hands do not grip a boat to move it. Tongs engage two holes at the end of the boat to move it. The other items in the glovebox are described below and the corner position of the boats is considered to adequately model reflection from operator's bodies, from operator's hands and arms, and from equipment inside the glovebox. 
The boats contain $2.75 \mathrm{~kg}$ of plutonium oxide mixed with water that fills the boat. This arrangement is the most reactive mixture for a $2.75 \mathrm{~kg}$ plutonium batch in a boat volume. The model uses the full volume of the boats. The basin and precipitation tanks contain a $2.75 \mathrm{~kg}$ batch of plutonium. The $1 / 8$ in. layer of $3 \mathrm{~g} \mathrm{Pu} / \mathrm{cm}^{3}$ is retained on the floor. The boats at the boat dock, bot plate, and basin are filled with water. Filling eight boats with a batch of plutonium when only four boats are allowed is considered incredible. The two inch high drip pan is also filled with water to add to the reflectors in the glovebox. The $\mathrm{k}_{\mathrm{eff}}$ for this model, case cc103, is $0.9312 \pm 0.0005$. This contingency case shows that an accidental grouping of four boats with one batch of $2.75 \mathrm{~g}$ of plutonium in each is within allowables. This grouping is the contingency case for allowing one boat in transit to move near the boat dock or the basin with an adjacent boat. Because the boat area of the glovebox is so congested, a $25.4 \mathrm{~cm}$ (10 in.) spacing of a boat being moved is certainly difficult and may be impossible. This analysis shows that a three boat grouping is double contingent.

Case cc5 takes an extra boat with the base case loading of $2.75 \mathrm{~kg}$ of plutonium at metal density mixed with water at a concentration of $1.22 \mathrm{~g} \mathrm{Pu} / \mathrm{cm}^{3}$ and an $\mathrm{H} / \mathrm{X}$ of 19 and puts it on top of the two boats in the boat dock. The three boats are arranged with the boats long sides adjacent and with the third boat centered over the two below. All three boats have an inch of water over the exposed top of each boat. Below the bottom two boats is an $1 / 8$ in. layer of $3 \mathrm{~g} \mathrm{Pu} / \mathrm{cm}^{3}$ of plutonium and below that is full water reflection from below the glovebox floor. This arrangement of boats violates spacing and stacking prohibitions. The $k_{\text {eff }}$ of this case is $0.8871 \pm$ 0.0006 . Case $\operatorname{cc} 5$ shows having an extra boat stacked is within the $k_{\text {eff }}$ allowable limit of 0.942 for non-metal plutonium systems and is doubly contingent.

Since the boat dock has two boats normally and another boat could be in transit close to the boats in the dock, a contingency run is made with all boats allowed in the glovebox in one group. The boats stacking prohibition is violated twice. If four boats are arranged in a wall between the boat dock and the corner of the glovebox against the side of the glovebox as shown in Figure E16 , a $\mathrm{k}_{\text {eff }}$ of $0.8921 \pm 0.0005$ results. In this case, $\mathrm{cc} 10$, the boats are head-to-head and stacked two high. Each boat has $2.75 \mathrm{~kg}$ plutonium in water filling the boat volume. The two boats on the top are covered by an inch of water. The boats at the boat dock, hot plate, and basin, are modeled as water since having eight batches is not credible. The batch in the tanks and in the vacuum basin were kept.

\subsubsection{Aggregate of Unspaced Containers}

Glovebox 3 has numerous containers that are allowed to move about the glovebox. Case cwcc7 shows that the worst case grouping of these containers with an extra boat is within allowables. This model includes the mass and volume of the containers free to move about the glovebox. The model used is to have batch masses in the vacuum filter basin and around the basin. The cwcc7 model is used to bound the contingent grouping of containers at the basin and at the boat dock. These are the two places in the glovebox where a grouping of containers begins with two adjacent $2.75 \mathrm{~kg}$ Pu batches. This case includes four $2.75 \mathrm{~kg}$ batches, the $1.5 \mathrm{~kg}$ sweeps can, and other containers filled with $250 \mathrm{~g} \mathrm{Pu} / \mathrm{L}$ plutonium nitrate solution. The model includes a boat in transit, one boat allowed next to the basin, and a third boat next to the basin 
that is the contingent event to bound the basin area and over four boats to bound the boat dock area.

The worst case arrangement has all the containers grouped around the vacuum filter basin because the basin adds the most volume to the model. None of the containers are stacked. Stacking would violate the stacking limit, introducing a second contingency event. This model explicitly incorporates the mass and volume of: (1) the vacuum filter basin with more than the $2.75 \mathrm{~kg}$ batch of plutonium; (2) three boats with a $2.75 \mathrm{~kg}$ plutonium batch each; (3) the $1 / 2 \mathrm{~L}$ sweeps can with $1.5 \mathrm{~kg}$ of plutonium; (4) the $1 \mathrm{~L}$ leak detection bottle filled with $250 \mathrm{~g} \mathrm{Pu} / \mathrm{L}$ feed solution; (5) three $250 \mathrm{~mL} \mathrm{pH}$ sample containers filled with $250 \mathrm{~g} \mathrm{Pu} / \mathrm{L}$ feed solution. The twelve sample bottles of up to $50 \mathrm{~mL}$ each filled with $3 \mathrm{~g} \mathrm{Pu} / \mathrm{L}$ filtrate are considered bounded by the extra mass and volume in the vacuum filter basin modeled with a larger than the design diameter and the reflection around model and around the glovebox. The boats $(2.5 \mathrm{in}$. high sides), the half liter sweeps can (3.5 in.), and the up to $50 \mathrm{~mL}$ sample bottles have the material in these containers normally less than 3 in. high, except the $1 \mathrm{~L}$ leak detection bottle which would have $450 \mathrm{~g} \mathrm{Pu}$ at most. Modeling the containers grouped around the basin as $3.1 \mathrm{in}$. tall is consistent with the average mass height and based on the fissionable mass being as close to the rest of the fissionable material as possible.

To analyze the aggregate of these five types of containers, two concentric cylinders are arranged around the vacuum filter basin with an inch of water reflector above and around the 3.1 in. tall model. The model has full water reflection below from the water under the floor. The 17.5 in diameter basin, filled 2.1 in. deep with $1.22 \mathrm{~g} \mathrm{Pu} / \mathrm{L}$ as plutonium oxide in water, includes more volume and mass than that for three boats. Actually the basin is 3.68 boat volumes with a total of $10.1 \mathrm{~kg}$ of Pu (3.678 batches). This material is the most moderated material that can be made by the $2.75 \mathrm{~kg}$ batch of plutonium allowed in a boat dispersed over the modeled $2.25 \mathrm{~L}$ volume of a boat. This material is the most reactive that can be made in a boat by a batch of plutonium. The portion of the basin volume below the perforated plate is modeled conservatively as one inch of water instead of the air that would normally be there.

The 17.5 in. diameter basin with this material bounds the other location in the glovebox that can have four batches with only one contingency, the boat dock. Four boats at the boat dock would cover an area of $22 \mathrm{in.}$ by $10 \mathrm{in}$. The $17.5 \mathrm{in}$. diameter basin has a larger area $240.6 \mathrm{sq}$. inches. The basin is modeled as holding only 3.678 batch masses and volume because the upper basin is only $2.1 \mathrm{in}$. high. The boats are $2.5 \mathrm{in}$. high. However, the boats have holes at $1.75 \mathrm{in}$. above the outside bottom of the boat at the two ends of the boat. Operators do not normally fill the boats above the holes. The $2.1 \mathrm{in}$. height of the basin is a conservative model of the material in a boat. The model has significant extra plutonim mass because the next concentric cylinder around the basin has the mass and volume of three boats. Also the fissionable material is reflected by one inch of water over the entire top of the model.

The first concentric cylinder around the basin contains the mass and volume of three boats of the same most reactive material as put in the basin. The height of this cylinder is $3.1 \mathrm{in}$., which is taller than the boats. This adds three boats worth of material to the model. The next concentric cylinder models the remainder of the containers is also $3.1 \mathrm{in}$. tall. This volume is conservatively filled with $250 \mathrm{~g} \mathrm{Pu} / \mathrm{L}$ plutonium nitrate solution and contains $1.625 \mathrm{~kg}$ of 
plutonium. The volume is calculated by taking all the mass in the non-boat containers, $1.675 \mathrm{~kg}$ $\mathrm{Pu}$, divided by $250 \mathrm{~g} \mathrm{Pu} / \mathrm{L}$. The $250 \mathrm{~g} \mathrm{Pu} / \mathrm{L}$ is the most reactive concentration of plutonium nitrate solution. The $1.5 \mathrm{~kg}$ of plutonium conservatively assumed to be in the half liter sweeps can is being model as the $250 \mathrm{~g} \mathrm{Pu} / \mathrm{L}$ plutonium nitrate solution the increase in volume and increaed moderator increases it reactivity. This configuration has a one inch water reflector on the sides and top and full water reflection from the bottom of the glovebox. The tanks are modeled as in the base case with 6 in. of $3 \mathrm{~g} \mathrm{Pu} / \mathrm{L}$ solids $(9 \mathrm{~kg})$ and $100 \mathrm{~g} \mathrm{Pu} / \mathrm{L}$ plutonium nitrate solution in the remaining volume of the tank. The $k_{\text {eff }}$ for the case cwcc7 is $0.8864 \pm 0.0005$. This contingency case shows that an aggregation of four batches and the containers that can move about the glovebox are within the allowable limit of 0.942 .

\subsubsection{Seismic with Intact Tanks}

The analysis of Glovebox 3 depends on the six tanks being spaced as specified in the limits of Section 3 of this CSER. A seismic analysis (Zook 1999) found that a design basis earthquake displaces the tanks only a fraction of an inch. This displacement is less than the $2.54 \mathrm{~cm}$ ( 1 in.) or more tank spacing used in this CSER analysis (see Appendix F). However, the struts and bolting supporting the tanks have not been specified and procured as safety class materials. If the materials are not safety class, their integrity and physical properties can not be assumed to be those specified in the design and used in the seismic displacement analysis. Because the hardware to space the tanks is not safety class, movement of the tank in an earthquake is analyzed as a contingent event in this CSER.

A seismic event that moves the six intact tanks together is considered an unlikely event. The tank contents can be modeled at normal fissionable loading in an unlikely event. Three of the tanks have six inches of $3 \mathrm{~g} \mathrm{Pu} / \mathrm{cm}^{3}$ as $\mathrm{PuO}_{2}$ at the bottom of the tanks as precipitate and $10^{-3} \mathrm{~g} \mathrm{Pu} / \mathrm{L}$ filtrate filling the remainder of the tanks. Precipitated plutonium is more reactive than when in solution. The amount and density of plutonium in the three precipitation tanks are conservative. Each of the three tanks contains $9 \mathrm{~kg}$ of plutonium, a total of ten batches. The other three tanks in Glovebox 3 normally have no plutonium. In this analysis, they too are modeled as precipitation tanks. The bottom six inches of these tanks also have one inch of water reflection around the outside of the tanks. This is possible because the flanges on the tanks keep the tanks separated by about an inch. For this seismic event, the six tanks are clustered in the center of the glovebox as shown in Figure E-17 in Appendix E. The glovebox is modeled with full water reflection around the sides and bottom. The cluster is not in a corner for maximum reflection and the cluster may not be optimal arranged. However, the cluster is much more tightly packed than could be expected in a seismic event. Full water reflection on the sides and bottom of a smaller glovebox is considered extremely conservative for an earthquake event when operators would not be adjacent to the glovebox and firefighters and fire fighting water would not be surrounding the glovebox with inches of water. Boats are not included in this model because if the tank moves to the end of the glovebox, they are expected to break. And the drip pan, boat dock bar, hot plate shield supports, vacuum filter basin and it's piping, struts, and piping are expected to restrict boats to the hot plate area where boats are restricted in normal operations. Since the glovebox is seismically qualified and would remain horizontal, there is no slope to slide the boats toward the tanks. The $\mathrm{k}_{\text {eff }}$ for the six tank clustered is $0.9207 \pm 0.0014$. 
This value is less than the 0.942 limit for non-metal plutonium systems and shows that the glovebox is double contingent for an event moving the tanks toward each other.

\subsubsection{Seismic and Fire Cases with Broken Tanks}

The seismic (cc5) and fire (cc6) contingencies are analyzed with fully loaded boats filled with sprinkler water and 3.25 in. of water on the glovebox floor. For the seismic event, the tanks are modeled as breaking and the solution is added to the water on the glovebox floor above the $1 / 8$ in. holdup layer. Both the density of the water mist in the air and the density of the plutonium oxide in the boats affect the glovebox $\mathrm{k}_{\text {eff. }}$. Table 5-3-2 lists plutonium densities in water for boats used to calculate the $k_{\text {eff }}$ presented in Table 5-3-3. Since the glovebox $k_{\text {eff }}$ is shown not to vary with plutonium density in the boats, any of these densities can be used for the parametric study of $\mathrm{k}_{\text {eff }}$ verses water mist density in the glovebox.

Table 5-3-2. Plutonium/Water Mixture Parameters for Density Range of 0.2 to $5.5 \mathrm{~g}$ $\mathrm{Pu} / \mathrm{cm}^{3}$ in a Furnace Boat

\begin{tabular}{|c|c|c|c|c|c|c|c|c|}
\hline $\begin{array}{c}\text { Pu } \\
\text { Density } \\
\left(\mathbf{g} / \mathbf{c m}^{\mathbf{3}}\right)\end{array}$ & $\begin{array}{c}\text { Pu } \\
\text { Mass } \\
(\mathbf{g})\end{array}$ & $\begin{array}{c}\mathbf{H}_{\mathbf{2}} \mathbf{O} \\
\text { Mass } \\
(\mathbf{g})\end{array}$ & $\begin{array}{c}\text { Total } \\
\text { Mass } \\
(\mathbf{g})\end{array}$ & $\begin{array}{c}\text { Mix } \\
\text { Density } \\
\left(\mathbf{g} / \mathbf{c m}^{\mathbf{3}}\right)\end{array}$ & $\begin{array}{c}\text { Wt. } \\
\text { Frac. } \\
\mathbf{H}\end{array}$ & $\begin{array}{c}\text { Wt. } \\
\text { Frac. } \\
\mathbf{O}\end{array}$ & $\begin{array}{c}\text { Wt. } \\
\text { Frac. } \\
\mathbf{P u}\end{array}$ & $\begin{array}{c}\mathbf{H} / \mathbf{X} \\
\text { Ratio }\end{array}$ \\
\hline 0.20 & 451 & 2209 & 2660 & 1.180 & 0.0929 & 0.7383 & 0.1695 & 130 \\
\hline 0.50 & 1127 & 2142 & 3269 & 1.451 & 0.0728 & 0.5825 & 0.3447 & 50 \\
\hline 1.00 & 2253 & 2030 & 4284 & 1.901 & 0.0527 & 0.4213 & 0.5260 & $\frac{24}{22}$ \\
\hline 2.00 & 2500 & 1003 & 3503 & 2.802 & 0.0318 & 0.2544 & 0.7138 & 2 \\
\hline 5.50 & 2500 & 207 & 2707 & 5.956 & 0.0085 & 0.0680 & 0.9235 & 2 \\
\hline
\end{tabular}

Table 5-3-3. Calculational Results for Plutonium/Water Mixtures in a Furnace Boat

\begin{tabular}{|c|c|c|c|c|}
\hline \multirow[t]{2}{*}{$\begin{array}{c}\text { Pu Density } \\
\left(\mathrm{g} / \mathrm{cm}^{3}\right)\end{array}$} & \multicolumn{2}{|c|}{$\begin{array}{c}\text { Without Water on Top of } \\
\text { Plutonium }\end{array}$} & \multicolumn{2}{|c|}{$\begin{array}{c}\text { With Water on Top of } \\
\text { Plutonium }\end{array}$} \\
\hline & $\mathbf{k}_{\mathrm{eff}}$ & $\sigma$ & $\mathbf{k}_{\mathrm{eff}}$ & $\sigma$ \\
\hline 0.20 & 0.8861 & 0.00059 & \multicolumn{2}{|c|}{ Boat Full of Plutonium } \\
\hline 0.50 & 0.8853 & 0.00064 & \multicolumn{2}{|c|}{ Boat Full of Plutonium } \\
\hline 1.00 & 0.8854 & 0.00058 & \multicolumn{2}{|c|}{ Boat Full of Plutonium } \\
\hline 2.00 & 0.8856 & 0.00061 & 0.8841 & 0.00064 \\
\hline 5.50 & 0.8861 & 0.00058 & 0.8855 & 0.00060 \\
\hline
\end{tabular}

The mist atmosphere simulates fire-fighting activities and the general effect of varying density of $\mathrm{H}_{2} \mathrm{O}$ filling the glovebox. It also conservatively accounts for large numbers of plastic waste packages used for cleanup in the glovebox. The 1 in. water reflectors around containers and the water around the glovebox are removed from this analysis. 
The interspersed moderation analysis at a conservative limiting unit mass (batch) of $2.5 \mathrm{~kg}$ plutonium of Glovebox 3 showed (Figure 5.3.1) a monotonically increasing $\mathrm{k}_{\text {eff }}$ from 0.001 $\mathrm{g} / \mathrm{cm}^{3}\left(k_{\text {eff }}=0.8250\right.$, case $\left.\mathrm{cl} 11\right)$ to full water density $\left(k_{\text {eff }}=0.9410\right.$, case $\left.\mathrm{cl} 121\right)$. No intermediate peak was identified even though the region around $0.05 \mathrm{~g} / \mathrm{cm}^{3}$, where a peak has been observed during vault analyses, was examined carefully. Full water flooding is not credible due to the criticality drain. Double contingency is met.

Figure 5.3.1 Interspersed Moderation Contingency

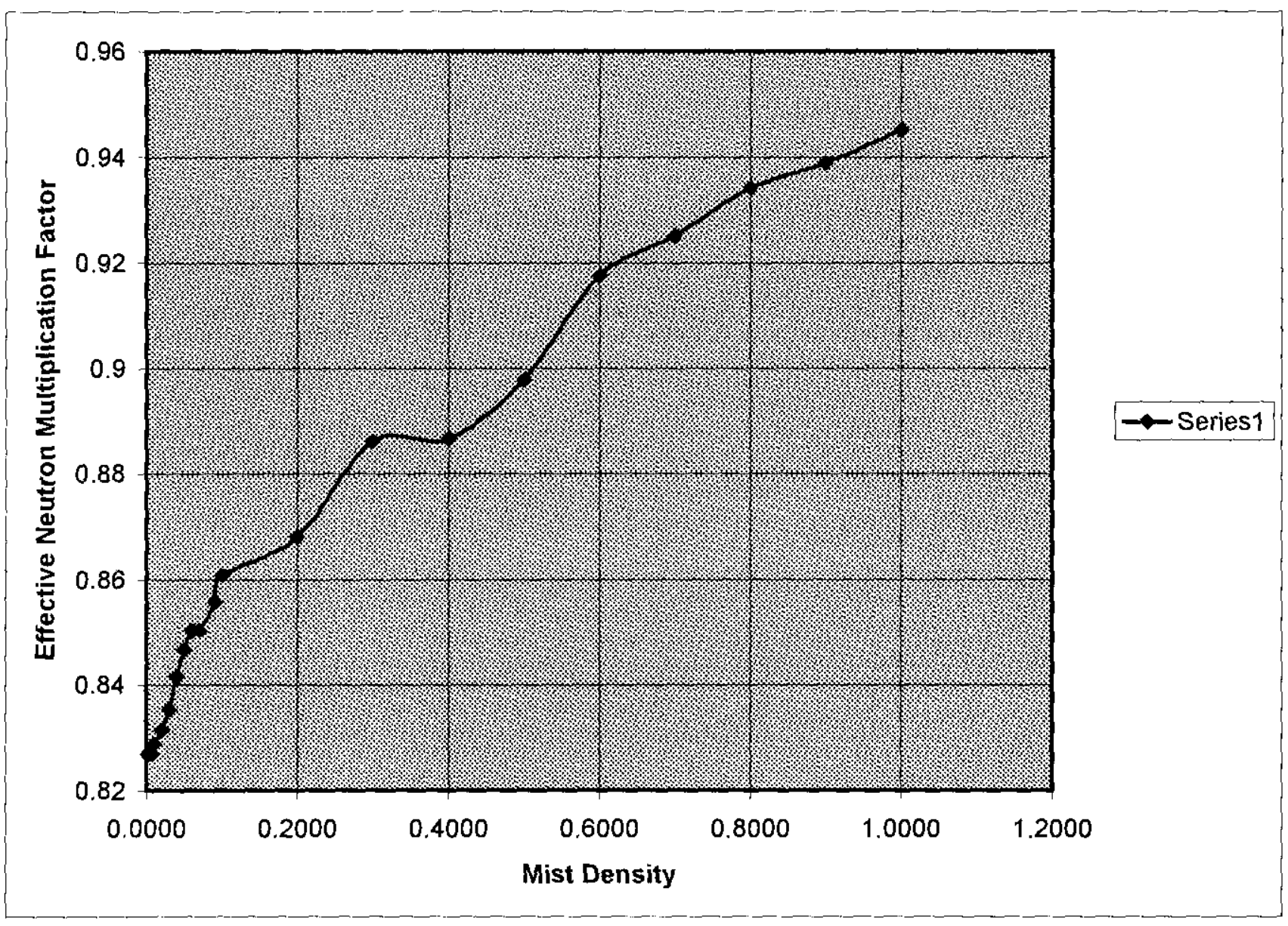

\subsubsection{Plutonium Container Against the Glovebox}

Plutonium bearing containers are not needed for Gloveboxes 3 and 5 and would not normally be brought around these gloveboxes. However, in the case a plutonium container is brought closer to the glovebox than the 18 in. spacing reqired by the PFP transportation criticality prevention specification, case $\mathrm{cc} 7$ was run. The worst case container for a well moderated and reflected glovebox is the conservative bagless transfer container (BTC) with 4.5 $\mathrm{kg}$ at $7.66 \mathrm{~g} \mathrm{Pu} / \mathrm{cm}^{3}$ as plutonium nitrate and beryllium oxide filling the remainder of the $2.26 \mathrm{~L}$ BTC. The can was modeled against the side of the glovebox inside the full water reflector next to the vacuum filter basin (Figure E-18). The resulting $k_{\text {eff }}$ of $0.9105 \pm 0.0006$ shows that 
Glovebox 3 is double contingent for plutonium bearing containers at PFP getting closer than transportation spacing allows.

\subsubsection{Double Batched Vacuum Filter Basin}

The batch of $2.5 \mathrm{~kg}$ of plutonium precipitated allowed in the three precipitation tanks is filtered out of the filtrate by a filter in the vacuum filter basin. The filter is supported by a perforated plate $17 \mathrm{in}$. in diameter at the bottom of a $2 \mathrm{in}$. high cylinder around the perforated plate. A space at most an inch deep slopes to the center from the sides below the perforated plate and draws off the filtration with a vacuum. Then the precipitate cake is to be scraped off the filter into a boat. If a second batch of precipitate from the three precipitation tanks were filtered through the vacuum filter basin before the first batch was removed, the basin would be double batched. This event would be a breakdown in the operations procedure and accountability of $2.5 \mathrm{~kg}$ of plutonium and is considered an unlikely event.

The basin was modeled as 17.5 in. diameter with $5.5 \mathrm{~kg}$ of plutonium at metal density mixed with water filling the upper basin without a filter. A metal water mixture was used in the model because it is more reactive than plutonium hydroxide. The space below the perforated plate was modeled containing air as expected during normal operation of the basin. The conservatism of $450 \mathrm{~g} \mathrm{Pu} / \mathrm{L}$ solution in the conservatively modeled one inch space below the perforated plate in the basin is removed. The double batched vacuum filter basin case cc8 had a $k_{\text {eff }}$ of $0.8741 \pm 0.0005$. This is within an allowable limit of 0.942 for non-plutonium metal systems and shows the glovebox is double contingent for double batching of the vacuum filter basin.

To ensure that the vacuum filter basin is geometrically favorable to contain precipitation cake, several runs were made filling the basin with dense plutonium oxide. The precipitate cake has been found experimentally to be about $0.2 \mathrm{~g} \mathrm{Pu} / \mathrm{cm}^{3}$. The 2.1 in. deep upper portion above the perforated plate without a filter taking up any room is filled with $2 \mathrm{~g} \mathrm{Pu} / \mathrm{cm}^{3}$ density plutonium oxide. This case, ccs, with $14.9 \mathrm{~kg}$ of plutonium has a $\mathrm{k}_{\text {eff }}$ of $0.9352 \pm 0.0005$. This value is within the allowable limit of 0.942 so the basin is geometrically favorable for over five batches of precipitate. If the bottom portion below the perforated plate, modeled as one inch deep, is also filled with $2 \mathrm{~g} \mathrm{Pu} / \mathrm{cm}^{3}$ density plutonium as oxide, the $22.3 \mathrm{~kg}$ of plutonium in the basin has a $k_{\text {eff }}$ of $0.9661 \pm 0.0006$. Although this case ccs 1 result is above the allowable limit, it is adequately subcritical. The $22.3 \mathrm{~kg}$ mass accumulation would require almost nine batches of precipitate. Certainly, an incredible amount and it would have to be ten times denser than that resulting from the magnesium hydroxide process. Based on these cases, ccs and ccsl, the vacuum filter basin is considered to be geometrically favorable for use in the magnesium hydroxide process.

\subsubsection{Sweep Can}

A sweeps can is not explicitly modeled in the base case nor is there a spacing limit on its movement. The sweeps can is limited to a half liter so a full can would only be expected to hold 
$250 \mathrm{~g}$ for conservative density of plutonium precipitate, $0.5 \mathrm{~g} \mathrm{Pu} / \mathrm{cm}^{3}$ (See Appendix F), or $570 \mathrm{~g}$ for plutonium nitrate, $2.9 \mathrm{~g} \mathrm{Pu}\left(\mathrm{NO}_{3}\right)_{4} 5 \mathrm{H}_{2} \mathrm{O} / \mathrm{cm}^{3}$. These are the two materials that could be spilled, dry, and then be swept up into a sweeps can. The extra amount of solids modeled in each filtrate tank by being modeled with excessive diameter is far more than is considered credible to be in the sweeps can. This excessive plutonium in the solids of each tank is considered to include the mass that could be in a sweeps can, especially because the precipitation tanks also are filled with plutonium nitrate solution. No control is placed on the movement of the sweeps can because the shape of the solids in the tank is a 6 in. high by 6 in. diameter cylinder. A separate sweeps can with a tank would have a less reactive geometry than an $\mathrm{H}=\mathrm{D}$ right cylinder formed by the segment of the tank filled with solids. The analysis of the sweeps can among the boats and vacuum filter basin carried out in Section 5.3.4.

\subsubsection{High Enriched Uranium}

The feed solutions contain both plutonium and uranium. Most uranium enrichments are less than $25 \mathrm{wt}$. \%. Higher enrichment uranium is unlikely but remains a concern. CSER 99-003 (Marusich 1999) reported that for equal mass, Pu-239 is more reactive than U-235 except at fissionable material concentrations of $100 \mathrm{~g} / \mathrm{L}$ to $1,000 \mathrm{~g} / \mathrm{L}$. The report compared the reactivity of high enriched uranium ( $94 \mathrm{wt} . \% \mathrm{U}-235 \mathrm{in}$ U-238) at different fissionable material concentrations in water with $100 \% \mathrm{Pu}-239$ in water. It showed that uranium (U-235 in U-238) at fissionable material concentrations below $100 \mathrm{~g} / \mathrm{L}$ and above $1,000 \mathrm{~g} / \mathrm{L}$ or uranium at enrichments up to $50 \mathrm{wt} . \%$ in U-238 is less reactive than equal mass of Pu-239. Uranium solutions of less than $100 \mathrm{~g} \mathrm{Pu} / \mathrm{L}$ are less reactive than the evaluated plutonium at less than $100 \mathrm{~g}$ $\mathrm{Pu} / \mathrm{L}$. Since feed solutions are limited to uranium with less than $50 \mathrm{wt} . \%$ and only uranium solution of less than $100 \mathrm{~g} \mathrm{Pu} / \mathrm{L}$ are allowed to be processed in this glovebox, two limits would have to be exceeded for an enrichment contingency. The double contingency requirement is met by these two limits for the uranium enrichment contingency.

\subsubsection{Summary}

This CSER shows that the designed magnesium hydroxide process controlled to the limits listed in Section 3.0 is acceptable in Glovebox 3 . No single credible event causes the $k_{\text {eff }}$ criticality safety limit of 0.95 to be exceeded. A calculational limit of $\mathrm{k}_{\text {eff }}=0.942$ specified in Appendix B is used to account for bias and computational uncertainty. Therefore, this CSER meets the requirements of the Double Contingency Principle for a criticality safety analysis specified in the Hanford Site Nuclear Criticality Safety Manual (HNF 1997b). 
HNF-6537 REV. 0

This page intentionally left blank. 


\subsection{REFERENCES}

ANSU/ANS-8.1, 1983: R1998, Nuclear Criticality Safety in Operations with Fissionable Materials Outside Reactors, American Nuclear Society, La Grange Park, Illinois.

Carter, R. D., G. R. Kiel, K.R. Ridgway, 1968, Criticality Handbook, ARH-600, 1980 Revision, Atlantic Richfield Hanford Company, Richland, Washington.

DOE, 1992, Nuclear Criticality Safety, DOE Order 5480.24, August 12, 1992, U.S. Department of Energy, Washington, D. C.

Erickson, D. G., 1998, MCNP 4B Plutonium Validation, HNF-1905, Rev. 1, CCVR 97-001, Fluor Daniel Northwest, Inc., Richland, Washington.

FDH, 1997, Criticality Safety General, Requirements, HNF-PRO-334, Rev. 0, Fluor Daniel Hanford, Inc., Richland, Washington.

FDH, 1997a, Criticality Safety Control of Fissional Material, HNF-PRO-537, Rev. 0, Fluor Daniel Hanford, Inc. Richland, Washington.

FDH, 1997b, Criticality Safety Evaluations, HNF-PRO-539, Rev. 0, Fluor Daniel Hanford, Inc., Richland, Washington.

Hummel, H. H., and D. Okrent, 1978, Reactivity Coefficients in Large Fast Power Reacors. American Nuclear Society.

Lan, J. S., 1999, MCNP Version 4B Approval for Use Documentation \& Authorized User List, FDNW-DSL-99-004, January 12, 1999, Fluor Daniel Northwest, lnc., Richland, Washington.

Marusich, R. M., 1999, CSER 99-003: Criticality Mass of Uranium as Compared to PlutoniumImplications for PFP Processing Uranium, HNF-4436, Rev. 0, Fluor Daniel Hanford, Richland, Washington.

Schwinkendorf, K. N., 1998, Software Certification Report for MCNP 4B, HNF-3316, Rev. 0, Fluor Daniel Northwest, Inc., Richland, Washington.

Zook, C. R., 1999, Magnesium Hydroxide Precipitation Process, Design Criteria Document, Fluor Daniel Northwest, Inc., Richland, Washington. 
HNF-6537 REV. 0

This page intentionally left blank.

$6-2$ 
HNF-6537 REV. 0

APPENDIX A - INDEPENDENT REVIEW COMMENTS AND CHECKLIST 
HNF-6537 REV. 0

This page intentionally left blank. 
FLUOR DANIEL, NORTHWEST

\section{TECHNICAL PEER REVIEWS}

\section{CHECKLIST FOR TECHNICAL PEER REVIEW}

Document Reviewed: HNF-6537, Rev. 0

Title:

CSER 00-003: Criticality Safety Evaluation Report for PFP Magnesium Hydroxide Filtrate Storage for Plutonium Stabilization Glovebox 3

Author: ' J. S. Lan and E. M. Miller

Date: $\quad 6 / 30 / 00$

Scope of Review: MCNP aalculations; inputs + outputs.

\section{Yes No* NA}

[ ] [ ] $/^{*}$

l] [ $/ 1$

[ ] [ ]

[] []

I [ ] []

[于 [ ] [ ]

H] [] []

$x][]$

H [ ] [

I [ ] [ ]

J [ ] [ ]

[X [ ] [3

[] [ ]

[] [ ]

[ ] [ ]

[ ] [ ]

[ ] [ ]

[ ] [ ]

(1)

[

Previous reviews complete and cover analysis, up to scope of this review, with no gaps. Problem completely defined.

Accident scenarios developed in a clear and logical manner.

Necessary assumptions explicitly stated and supported.

Computer codes and data files documented.

Data used in calculations explicitly stated in document.

Data checked for consistency with original source information as applicable.

Mathematical derivations checked including dimensional consistency of results.

Models appropriate and used within range of validity or use outside range of established validity justified.

Hand calculations checked for errors. Spreadsheet results should be treated exactly the same as hand calculations.

Software input correct and consistent with document reviewed.

Software output consistent with input and with results reported in document reviewed. Limits/criteria/guidelines applied to analysis results are appropriate and referenced. Limits/criteria/guidelines checked against references.

Safety margins consistent with good engineering practices.

Conclusions consistent with analytical results and applicable limits.

Results and conclusions address all points required in the problem statement.

Format consistent with applicable guides or other standards.

Review calculations, comments, and/or notes are attached.

Document approved (i.e., the reviewer affirms the technical accuracy of the document).

S. R. Gedeon

Reviewer: (Printed and Signed)

Date 30 June 2000

* All "NO" responses must be explained below or on an additional page.

** Any calculations, comments, or notes generated as part of this review should be signed, dated and attached to this checklist. Such material should be labeled and recorded in such a manner as to be intelligible to a technically qualified third party.

NUCLEAR ENGINEERING 
FLUOR DANIEL NORTHWEST

\section{TECHNICAL PEER REVIEWS}

\section{CHECKLIST FOR TECHNICAL PEER REVIEW}

Document Reviewed: HNF-6537, Rev. 0

Title:

CSER 00-003: Criticality Safety Evaluation Report for PFP Magnesium Hydroxide

Author: Precipitation Process for Plutonium Stabilization Glovebox 3 Date: $\quad 6 / 30 / 00$

Scope of Review:

Yes $\quad$ No* NA

[ $\left[\begin{array}{l}\text { [ } \\ {[}\end{array}\right]^{* *}$ Previous reviews complete and cover analysis, up to scope of this review, with no gaps.

[U] [ ] [ ] Problem completely defined.

[ $\int[$ [ ] [ ] Accident scenarios developed in a clear and logical manner.

[M [ ] [ ] Necessary assumptions explicitly stated and supported.

[ ] [ ] [4 Computer codes and data files documented.

[ [ ] [ ] Data used in calculations explicitly stated in document.

[ ] [ ] [ J Data checked for consistency with original source information as applicable.

[ ] [ ] [U Mathematical derivations checked including dimensional consistency of results.

[ $\left[\begin{array}{l}\mathcal{H} \\ {[}\end{array}\right]$ Models appropriate and used within range of validity or use outside range of established validity justified.

[ ] [ ] [ J Hand calculations checked for errors. Spreadsheet results should be treated exactly the same as hand calculations.

[ ] [ ] [ [ S Software input correct and consistent with document reviewed.

[ ] [ ] [ $\mathcal{X}$ Software output consistent with input and with results reported in document reviewed.

[4 [ ] [ ] Linits/criteria/guidelines applied to analysis results are appropriate and referenced. Limits/criteria/guidelines checked against references.

[4 [ ] [ ] Safety margins consistent with good engineering practices.

[J [ ] [ ] Conclusions consistent with analytical results and applicable limits.

[UJ [ ] [ ] Results and conclusions address all points required in the problem statement.

[4 [ ] [ ] Format consistent with applicable guides or other standards.

[ ] [ ] [** Review calculations, comments, and/or notes are attached.

[U] [ ] [ ] Document approved (i.e., the reviewer affirms the technical accuracy of the document).

\section{R.F. Richard R.F.Rechaud}

Reviewer: (Printed and Signed)

* AIl "NO" responses must be explained below or on an additional page.

** Any calculations, comments, or notes gencrated as part of this revicw should be signed, dated and attached to this checklist. Such material should be labeled and recrorded in such a manner as to be intelligible to a technically qualified third party.

NUCLEAR ENGINEERING 
HNF-6537 REV. 0

\section{Peer Review Comments}

R. F. Richard, a qualified Criticality Safety Specialist of the Criticality and Shielding group in FFS, Safety Analysis and Nuclear Engineering, carried out an independent, technical review of HNF-6537, Rev. 0, CSER 00-003: Criticality Safety Evaluation Report for PFP Magnesium Precipitation Process for Plutonium Stabilization Glovebox 3. This review did not include verification of computer input and output files. The following comments were provided.

The evaluation is clearly conservative and demonstrates the double contingency principle. Plutonium nitrate solution (generally up to $330 \mathrm{~g} \mathrm{Pu} /$ liter, but no greater than $450 \mathrm{~g} \mathrm{Pu} /$ liter) will be blended to a low concentration in Glovebox 227S. The low concentration nitrate solution (up to $50 \mathrm{~g} \mathrm{Pu} /$ liter) will be transferred to the precipitation tanks of Glovebox 3. Plutonium Oxide will precipitate out and ultimately be transferred to a furnace boat. The remaining solution (on the order of $1 \times 10^{-3} \mathrm{~g} \mathrm{Pu} /$ liter) will be transferred to the phase separator tank.

Total plutonium mass in the three precipitation tanks is limited to $2.5 \mathrm{kgs}$. This limit is driven by the furnace boat $2.5 \mathrm{~kg}$ limit (batch process).

The precipitator, phase separator, and vacuum tanks all have a maximum inner diameter of 6.186 inches. ARH-600, Figure III.A.4.100-1, shows that for plutonium nitrate solution in an infinitely long cylinder, the minimum critical diameter is 6.4 inches with full water reflection. The most reactive concentration is $250 \mathrm{~g} \mathrm{Pu}$ / liter. For one inch water reflection, the minimum critical diameter is 7.9 inches. The evaluation base case assumed a concentration of $100 \mathrm{~g} \mathrm{Pu} /$ liter in the precipitation tanks with 6 inches of solids at the bottom of each tank. Also included are 4 furnace boats $(2.75 \mathrm{~kg}$ plutonium per boat) and an assortment of other containers necessary for the operation. The entire floor of the glovebox is conservatively modeled with a $1 / 8$ inch thick layer of $\mathrm{PuO}_{2}$ at $3 \mathrm{~g} \mathrm{Pu} / \mathrm{cm}^{3}$. This very conservative base case has a $\mathrm{k}_{\text {eff }}$ of 0.8825 .

Contingencies addressed the criticality parameters of mass, interaction, moderation, volume, concentration, and reflection. Contingencies analyzed were overbatching a boat, solution at optimum concentration, stacking boats, loss of spacing between boats, seismic and fire events. Calculations show that $\mathrm{k}_{\mathrm{eff}}$ for all contingencies are less than the required 0.942 .

Comments generated by this review were incorporated into the document.

This reviewer concurs that no single credible event will cause the $0.95 \mathrm{k}_{\text {eff }}$ criticality safety limit to be exceeded. Therefore, this CSER meets the double contingency principle. 
FLUOR DANIEL NORTHWEST

\section{TECHNICAL PEER REVIEWS}

\section{CHECKLIST FOR TECHNICAL PEER REVIEW}

Document Reviewed:

Title:

Author:

Date:

Scope of Review:
HNF-6537, Rev. 0

CSER 00-003: Criticality Safety Evaluation Report for PFP Magnesium Hydroxide

- Precipitation Process for Plutonium Stabilization Glovebox 3

J.S. Lan and E. M. Miller

$6 / 26,00$

Yes $\quad \underline{N 0^{*}} \quad \underline{N A}$

[ ] [ ] [X]** Previous reviews complete and cover analysis, up to scope of this review, with no gaps.

[X] [ ] [ ] Problem completely defined.

[X] [ ] [ ] Accident scenarios developed in a clear and logical manner.

[X] [ ] [ ] Necessary assumptions explicitly stated and supported.

$[x]$ [ ] [ ] Computer codes and data files documented.

(x] [ ] [ ] Data used in calculations explicitly stated in document.

[X] [ ] [ ] Data checked for consistency with original source information as applicable.

[ ] [ ] [x] Mathematical derivations checked including dimensional consistency of results.

[X] [ ] [ ] Models appropriate and used within range of validity or use outside range of established validity justified.

[ ] [ ] [X] Hand calculations checked for errors. Spreadsheet results should be treated exactly the same as hand calculations.

[ ] [ ] [X] Software input correct and consistent with document reviewed.

[ ] [ ] [X] Software output consistent with input and with results reported in document reviewed.

[X] [ ] [ ] Limits/criteria/guidelines applied to analysis results are appropriate and referenced. Limits/criteria/guidelines checked against references.

[X] [ ] [ ] Safety margins consistent with good engineering practices.

[X] [ ] [ ] Conclusions consistent with analytical results and applicable limits.

[X] [ ] [ ] Results and conclusions address all points required in the problem statement.

X] [ ] [ ] Format consistent with applicable guides or other standards.

[ ] $[X]^{* *}$ Review calculations, comments, and/or notes are attached.

[X] [ ] [ ] Document approved (i.e., the reviewer affirms the teclinical accuracy of the document).

W. A. Blyckert Ham-C./Shatent 6-26-00

Reviewer: (Printed and Signed)

Date

* All "NO" responses must be explained below or on an additional page.

** Any calculations, comments, or notes generated as part of this review should be signed, dated and attached to this checklist. Such material should be labeled and recorded in such a manner as to be intelligible to a technically qualified third party.

NUCLEAR ENGINEERING 


\section{Mohr and Associates}

\section{ENGINEERING - ANALYSIS - CONSULTING}

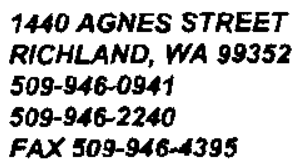

June 26,2000

To: $\quad$ Jay S. Lan, Edward M. Miller, and Hans Toffer, Fluor Federal Services, Inc

From: $\quad$ Warner A. Blyckert

Subject: $\quad$ Review of CSER 00-003: Criticality Safety Evaluation Report for PFP Magnesium Hydroxide Precipitation Process for Plutonium Stabilization Glovebox 3 (HNF-6537 Rev. 0)

Document HNF-6537, Rev. 0, CSER 00-003: Criticality Safety Evaluation Report for PFP Magnesium Hydroxide Precipitation Process for Plutonium Stabilization Glovebox 3 was given an independent technical review. The approach to analyzing the proposed operations and technique used were checked for suitability, accuracy and completeness.

The material which was reviewed consisted of the draft of the final report. The input and output files of the computer calculations were not reviewed so that no assessment was made of accuracy, convergence, or any other parameter of the results. The correctness and results of the validation effort were not reviewed so that the limits used in the CSER were not checked for accuracy nor applicability other than the narrative account of the approach which is reported in an appendix. The referenced CSERs and CSARs were not reviewed and the statements concerning their results were accepted without verification.

Responses to the reviewer's comments have been incorporated into the final report and adequately address the comments.

The reviewer agrees with the conclusion of the report that the proposed magnesium hydroxide filtrate storage for plutonium stabilization operation may be safely operated with the postulated material under the limiting conditions of operation.

Very truly yours,

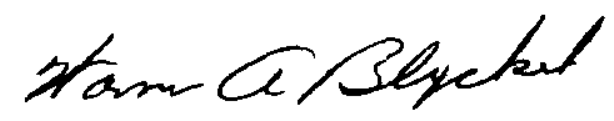

Warner A. Blyckert 


\section{HNF-6537 REV. 0}

This page intentionally left blank 
HNF-6537 REV. 0

APPENDIX B - MCNP4B COMPUTER CODE VALIDATION

B-1 


\section{HNF-6537 REV. 0}

This page intentionally left blank

B-2 


\section{B.1 VALIDATION PROCEDURE}

The validation of the computer code methods used in this analysis consisted of testing the code and neutron cross-section calculations against known critical configurations. These benchmark experiments have fissionable isotopes in systems similar to that evaluated by this CSER. The computed and measured $\mathrm{k}_{\mathrm{eff}} \mathrm{s}$ for the benchmark configurations were compared to establish a bias that includes the uncertainty in the calculational methods. A bias-adjusted $\mathrm{k}_{\text {eff }}$ for the benchmark systems was defined to include both the deviations for the calculated from the measured $k_{\text {eff }}$ 's, and experimental and calculational uncertainties along with the spread in the ability of the computer code to calculate similar systems. In addition, criticality safety criteria require that the bias-adjusted $\mathrm{k}_{\text {eff }}$ for CSER analysis calculations not exceed the established $\mathrm{k}_{\text {eff }}$ safety limit at the $95 \%$ confidence level.

This method is illustrated in Figure B.1. Critical is defined as a $\mathrm{k}_{\mathrm{eff}}$ of unity, adjusted by the bias established from the comparison of calculations with benchmarks. The bias combined with the safety margin of 0.05 (a safety limit that $\mathrm{k}_{\text {eff }}$ must be less than or equal to 0.95 ) to compare with the calculated value and statistical uncertainty of the computer calculated $\mathrm{k}_{\text {eff' }} \mathrm{s}$ of this CSER analysis. The calculated target $\mathrm{k}_{\text {eff }}$ is established by adding the bias, 0.05 , and 1.645 times the one-sigma uncertainty of the calculated $\mathrm{k}_{\mathrm{eff}}$ for the particular CSER analysis and subtracting that value from 1.0. For the analyses in this CSER, all the computer statistical uncertainties were less than \pm 0.002 , so this value was used to set the target $k$ as described in Section B.2

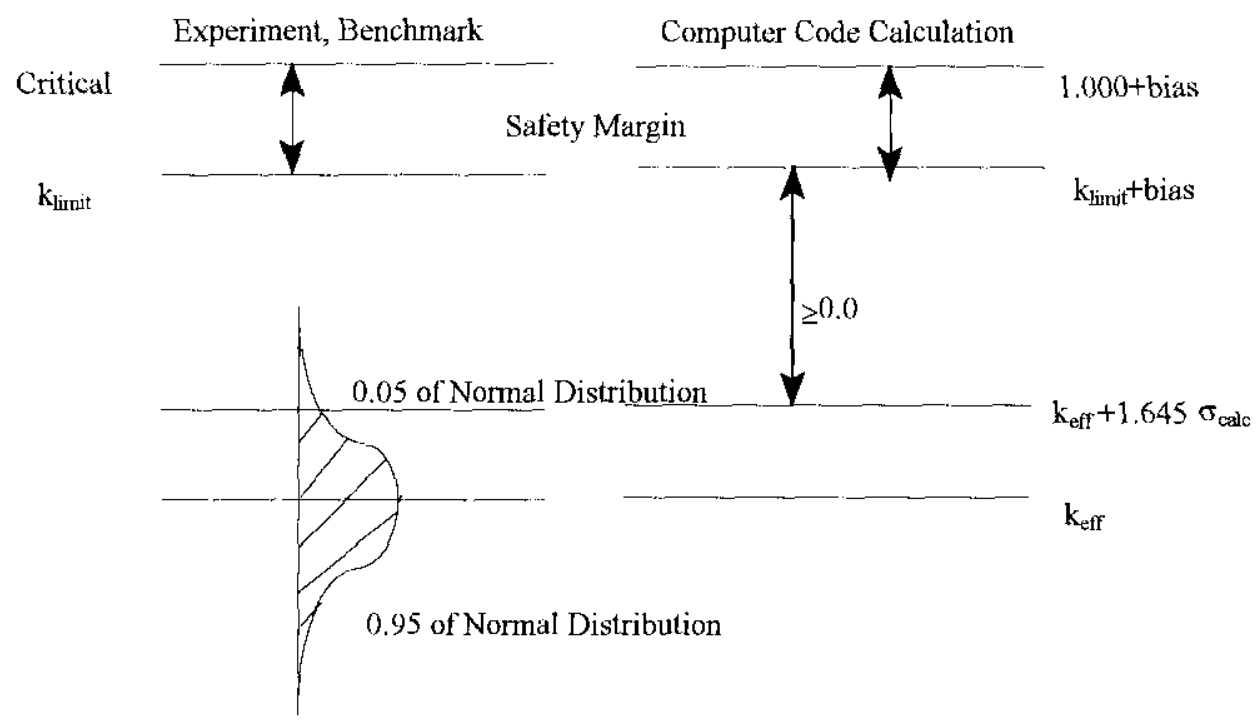

Figure B. 1. Logic of Validation Procedure 


\section{B.2 GENERIC VALIDATION FOR PLUTONIUM SYSTEMS}

A report by J. S. Lan, MCNP Version 4B Approval For Use Documentation \& Authorized User List (Lan 1999), presents the results of calculations to determine a generic bias for plutonium configurations, as encountered in the Plutonium Finishing Plant. One hundred and forty three benchmark experiments were calculated. There were different material types that were considered in the plutonium validation calculations:

- Plutonium metal,

- Plutonium oxide,

- Plutonium solutions,

- Plutonium solutions with cadmium (a neutron poison),

- Water and polystyrene moderators, and

- Water, plexiglass, paraffin, polyethylene, and steel and concrete reflectors

The lower tolerance limit $b_{L}$ was calculated for the benchmark experiments to have a $95 \%$ confidence that $95 \%$ of the benchmark calculated $\mathrm{k}_{\mathrm{efff}} \mathrm{s}$ are above that limit. This is expressed by the following formula:

$$
\mathrm{b}_{\mathrm{L}}=\mathrm{k}_{\mathrm{avg}}-\mathrm{K}_{\mathrm{b}} * \sigma_{\mathrm{avg}}
$$

where: $b_{\mathrm{L}}=$ lower tolerance limit for $95 \%$ confidence that $95 \%$ of benchmark calculated $\mathrm{k}_{\text {eff' }} \mathrm{s}$ is above this limit,

$\mathrm{k}_{\text {avg }}=$ the average of the $\mathrm{k}_{\text {eff }}$ 's calculated by MCNP 4B,

$\mathrm{K}_{\mathrm{h}}=\mathrm{a}$ multiplier found from statistical tables for non-central t-distribution, and depends on number of degrees of freedom, and

$\sigma_{\mathrm{avg}}=$ standard deviation of the MCNP $\mathrm{k}_{\mathrm{eff}} \mathrm{s}$.

Bias is calculated by the following formula:

$$
\text { bias }=b_{L}-k_{\text {crit }}
$$

where:

$\mathrm{k}_{\mathrm{crit}}=$ the average of the $\mathrm{k}_{\text {eff' }} \mathrm{s}$ for the critical experiments; for the plutonium experiments $\mathrm{k}_{\text {crit }}=1.000$.

The bias for the plutonium metal group was significantly different than for all other groups. For this reason, it was concluded that separate bias values for metal and non-metal groupings would be appropriate. The lower tolerance limit for the metal group (17 benchmark critical experiments) calculated to be 0.9884 . The lower tolerance limit for the non-metal group (126 benchmark critical experiments) calculated to be 0.9991 . These lower tolerance limits yielded the bias appropriate for each material category:

- Plutonium metal

- Plutonium non-metal bias is -0.0116 ,

bias is -0.0009 . 
- For conservatism, these calculated biases were recommended to be increased to:

- Plutonium metal

recommended bias is -0.0150 ,

- Plutonium non-metal recommended bias is -0.0050 .

The safety criteria for future calculations on undetermined systems requires that the bias-adjusted $\mathrm{k}_{\mathrm{eff}}$; $\mathrm{k}_{\mathrm{eff}}$, does not exceed 0.95 at the $95 \%$ confidence level. This is expressed by the following formula:

$$
\mathrm{k}_{\mathrm{eff}} *=\mathrm{k}_{\mathrm{eff}}-\text { bias }+1.645 * \sigma_{\text {calc }} \leq \mathrm{k}_{\text {limit }}
$$

where: $\mathrm{k}_{\mathrm{eff}} \quad=\mathrm{k}$ value given by MCNP $4 \mathrm{~B}$ calculation for system in question, bias $=-0.015$ for Pu metal, and -0.005 for Pu non-metal systems, $1.645=\mathrm{a}$ constant number of standard deviations for .95 of the distribution for a one-sided standard normal distribution

$\sigma_{\text {calo }}=$ standard deviation given by MCNP 4B calculation for system in question, and

$\mathrm{k}_{\text {limit }}=0.95$ for plutonium systems, generally.

$\mathrm{k}_{\text {limit }}$ is generally taken to be 0.95 for plutonium systems.

For a standard deviation $\left(\sigma_{\text {calc }}\right)$ of 0.002 or less, the $\mathrm{k}_{\text {eff }}{ }^{*}$ value for plutonium metal systems is:

$$
\begin{gathered}
k_{\text {eff }}-(-0.015)+1.645 * 0.002 \leq 0.95, \text { or } \\
k_{\text {eff }} \leq 0.95+(-0.015)-1.645 * 0.002=0.932 .
\end{gathered}
$$

On this basis, it is determined that the true $\mathrm{k}_{\text {eft }}$ of an analyzed configuration with plutonium will not exceed 0.95 with a $95 \%$ confidence level for plutonium metal systems if the calculated value ( $\mathrm{k}_{\mathrm{eff}}$, and $\left.\sigma \leq 0.002\right)$ is limited to a maximum value of $\mathbf{0 . 9 3 2}$.

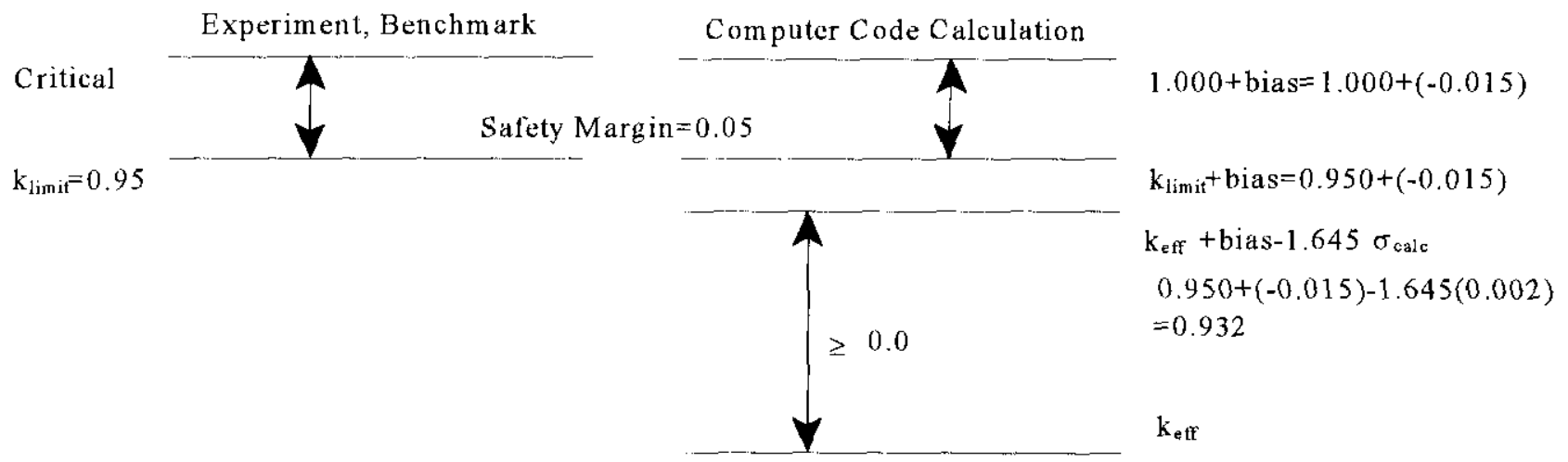

Figure B.2. Implementation of Validation Procedure 
For a standard deviation $\left(\sigma_{\text {ealc }}\right)$ of 0.002 or less, the $k_{\text {eff }}$ value for non-metal systems is:

$$
\begin{gathered}
\mathrm{k}_{\mathrm{eff}}-(-0.005)+1.645 * 0.002 \leq 0.95, \text { or } \\
\mathrm{k}_{\mathrm{eff}} \leq 0.95+(-0.005)-1.645 * 0.002=0.942
\end{gathered}
$$

On this basis, it is determined that the true $\mathrm{k}_{\mathrm{eff}}$ of an analyzed configuration with plutonium will not exceed 0.95 with a $95 \%$ confidence level for plutonium non-metal systems if the calculated value ( $k_{\text {eff, }}$ and $\sigma \leq 0.002$ ) is limited to a maximum value of $\mathbf{0 . 9 4 2}$.

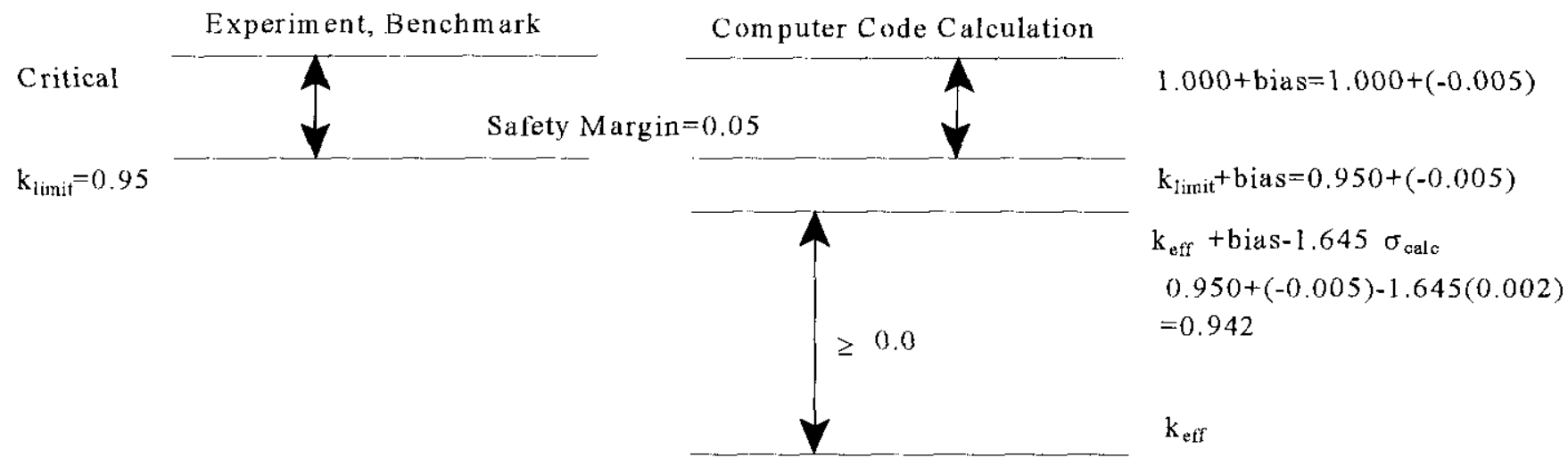

Figure B.3 Implementation of Validation Procedure

\section{B.3 VALIDATION OF MCNP 4B}

The validation of the MCNP4B code on the new computing system, Intergraph ${ }^{\text {TM }}, 400 / 450$ $\mathrm{MHz}$ Pentium II, personal computers was documented in Lan, 1999. The essence of the validation was cross-correlation of calculational results obtained with this code version and results of critical experiments, as reported in $M C N P$ Version $4 B$ Approval for Use Documentation \& Authorized User List (Lan 1999). 
HNF-6537 REV. 0

APPENDIX C - MCNP INPUT FILES

C-1 
HNF-6537 REV. 0

This page intentionally left blank.

C-2 
HNF-6537 REV. 0

Case noa

ingoh glove box 3 criticality, rurinal peraticul case, noa.

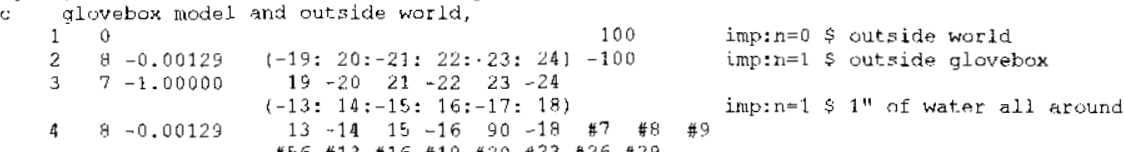

$4 \quad 9-0.00129 \quad 13-14 \quad 15-16 \quad 90-18 \quad \# 7 \quad \# 8 \quad \# 9$

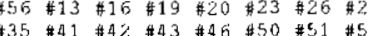

C.rank model, ( $\mathrm{Pu})$ 6.3" dia. $36.0 " \mathrm{~T} / \mathrm{T}, 20$

231

$6 \quad 8-0.00129$

$-36-35, \quad 34$

trelet $i$

Liters capacity, 12 liter for normal case

$u=2$ ima: $n=1$ \$ t $k-0012$, pre, tank $\left.40 \mathrm{~d} / \mathrm{I}_{1} \mathrm{Pu}(\mathrm{NO}) \mathrm{3}\right) 4$

tank relocations (Pu)

like 7 but 7 rol 2

$u=2$ inp: $n=1 \$$ air

tank model, (Pu)

$10 \quad 25-1.000001$

$55 \quad 8-0.001290$

550

like 7 but $\operatorname{trcl}=2$

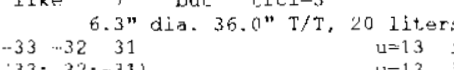

$\$$ t $k-001 b$, pre. tank $40 g / L$ Pu(NO3) 4

$-35-35:-31$

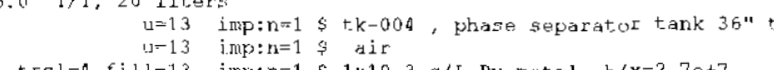

c tark model, $(\mathrm{P} / 2)$

$11 \quad 25 \quad-1.000001$

$12 \quad R-0.001290$

130

tank nodel, $\{$ Pu $\}$

$14 \quad 25-1.000001$

$15 \quad$ Q -0.001290

160

$\mathrm{trcl}=4$ fille 13 imptr
6.3 " dia. $12.0 " \mathrm{~T} / \mathrm{T}, 5.5$ litars

$-38-32 \quad 31$

3R: $32:-31$

$y=10$ impl $n=1$ \& t $k-005$, vacuum catch tank $12 " t$

-35
6.31

$x+10$ imp: $n=1$ \& ai

trcl=f fill $=10$ imp: $r=1$ \& $1 \times 10-3 \mathrm{~g} / \mathrm{L}$ Pu netal, $h / x=2.7 \mathrm{e}+7$

$\begin{array}{lll}-37 & -32 & 31 \\ (37 & -32:-31)\end{array}$

$-41-35 \quad 34$

polishing filter model, 6.3"

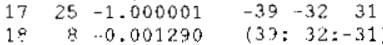

$\begin{array}{llll}19 & 9 & -0.001290 & 39: 32:-31 \\ 19 & 0 & -93-35 & 34\end{array}$

c polishing filter relocatiun

u=11 ink: $n=1 ; t k-006$, vacuum trap tank $22 " t$

$\mu=11$ imp: $n=1$ \& ais

trcl=6 fill=1t imp: $n=1$ \& $1 \times 10-3$ o/I, pu metal, $h / x=2.7 e+7$

ia. $15.5^{\circ} \mathrm{T} / \mathrm{T}$

like

$\cos =7$

If $=3$ imp: $n=1$ \& fll-002a, polishing tilter 16 " t

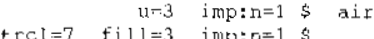

bijt $\quad+[C]=8$

\$ El-0o2b, polishing filtar

$16^{\prime \prime}+$

$21 \quad 25-1.00000 \quad-75 \quad-74 \quad 73$

22 \& $-0.001290 \quad(75: 74:-73)$

23 drip mon mel

c drip pan mode

$2425-1.000001 \quad 51-62 \quad 63-54 \quad 65-66 \quad$ 1 $25=5$ jmp: $n=1$ water in drip pan

25 - -0.00129 (-51:62:-63:64:-65:66)

$26067-69 \quad 69-70 \quad 71-72+r c 1=10$ fill=5 inep:n=1

sweeps model
$27 \quad 2$ P $-3.84854 \quad-27-26 \quad 25$

$28 \quad 9-0.00129 \quad(27: 26:-25)$

$290 \quad-30-29 \quad 28$

c wat filter model, height of

$30 \quad 11-7.94 \quad-41 \quad 44-48$

$31 \quad 8-0.00129 \quad-41$ 45 -44

$32 \quad 27-1.903 n-140.48$

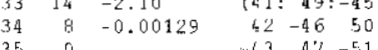

350

c dry filter model

$\begin{array}{rrl}36 & 11 & -7.94 \\ 37 & 7 & -1.00000\end{array}$

$\begin{array}{llllll}37 & 7 & -1.00000 & -41 & 45 & -44 \\ 39 & 7 & -1.00000 & -41 & 44 & -49\end{array}$

$4100.00129 \quad 42.45 \quad 50$

dry filter model

42

42 mordel

$\begin{array}{lll}-43 & 47 & -51\end{array}$

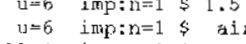

$u=4$ imp:n-1 \& pu in transter plup

He 4 mp: $n=1$ \$ $a$ is

Q3. like 41 but trol=15

$\operatorname{trcl}=11$ fill=6 imp: $n=1$ \$

$4425-1.927080 \quad 1 \quad-2 \quad 3 \quad-4 \quad 5 \quad-6 \quad 1=9$ imp:n=1 \$ furrace boat

$u=9$ imp: $n=1$ \$ 1 " of water

$46 \quad 0 \quad 7-4 \quad 3-10 \quad 11-12$ vrcl=15 filla: inp:n=1 s

C hot plate boat model

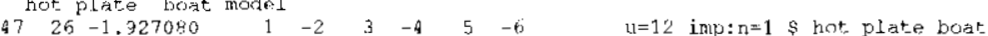

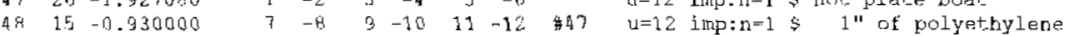

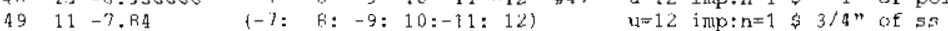

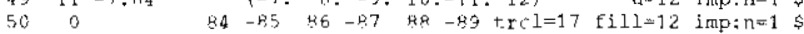

c. transition bast relixations

51 like 46 but trel=1

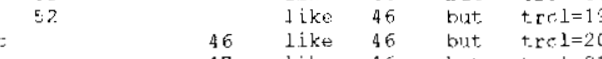

47 like 46 but trel $\operatorname{trc}=2$

1/40 thick layer of holdup in glove box

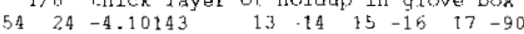

storage rack boat

storage rack boat 2

storage rack buat 3

$\$$ storage rack boat

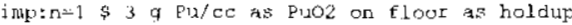

\begin{tabular}{|c|c|c|c|}
\hline 1 & py & -6.3500 & \\
\hline 2 & py & 6.3500 & $\$ 5 "$ \\
\hline 3 & $\mathrm{px}$ & -13.9700 & \\
\hline 4 & $\mathrm{px}$ & 13.9700 & $\$ 11 "$ \\
\hline s & $p 2$ & -3.1750 & \\
\hline 6 & $\mathrm{pz}$ & 3.1750 & $\$ 2.5 "$ \\
\hline 7 & $\begin{array}{l}\text { bort } \\
\text { py }\end{array}$ & -4.4900 & \\
\hline H & py & 4.8900 & $5 "$ " 1" water \\
\hline 9 & $\mathrm{px}$ & -16.5100 & \\
\hline 10 & $\mathrm{px}$ & 15.5100 & $11 "+1 "$ water \\
\hline
\end{tabular}


HNF-6537 REV. 0

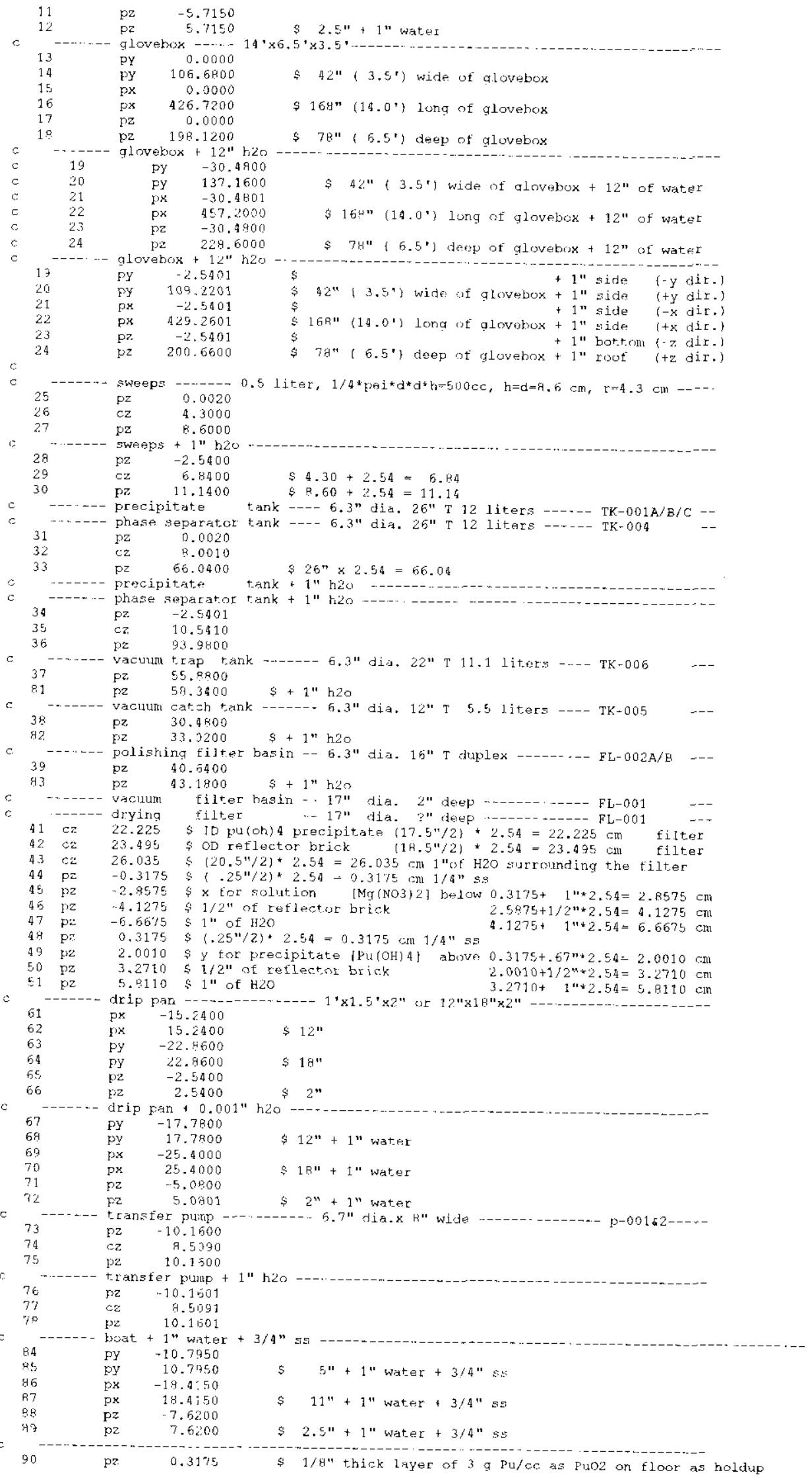


This page cannot be converted.

Please view the native document

for the original page. 


\section{HNF-6537 REV. 0}

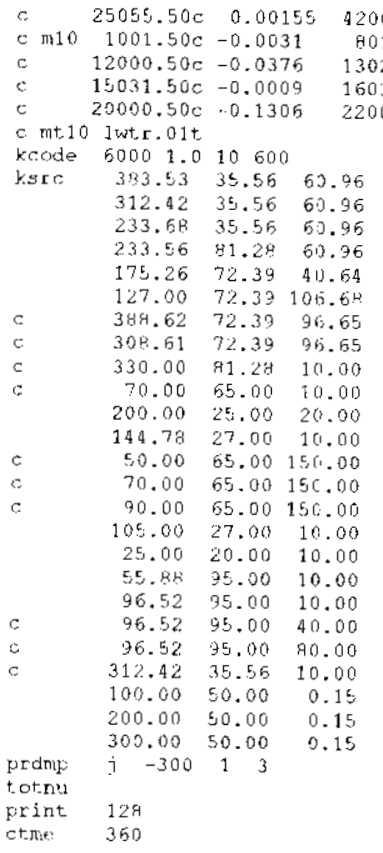

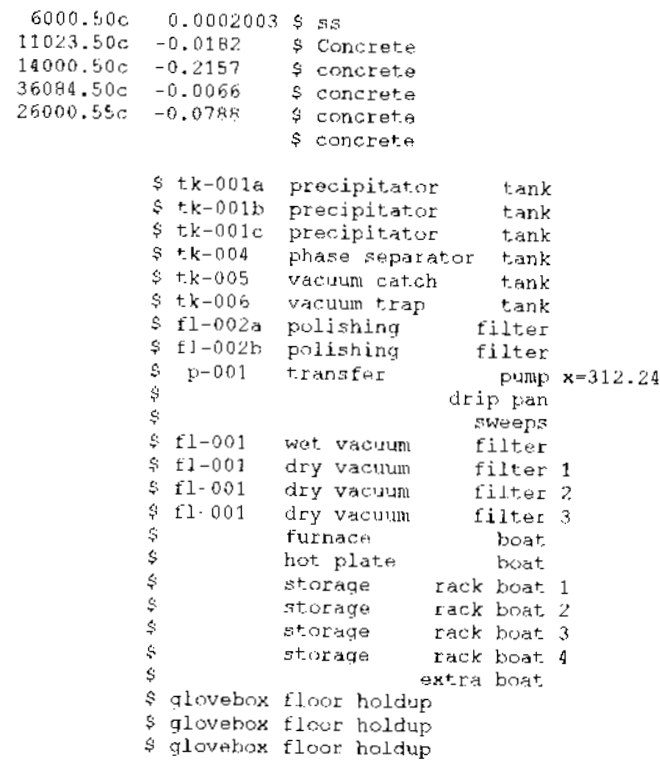

Case bc

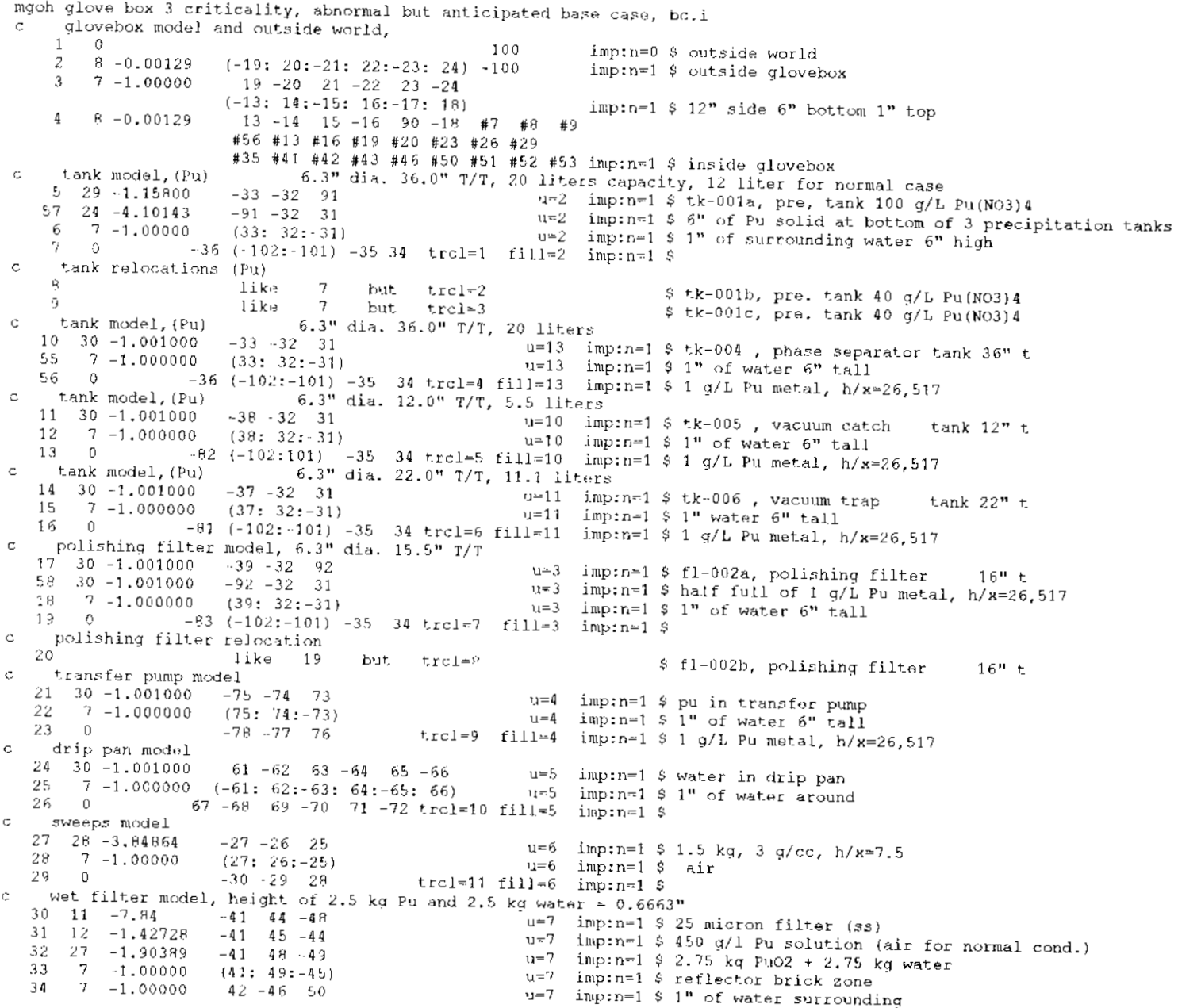


HNF-6537 REV. 0

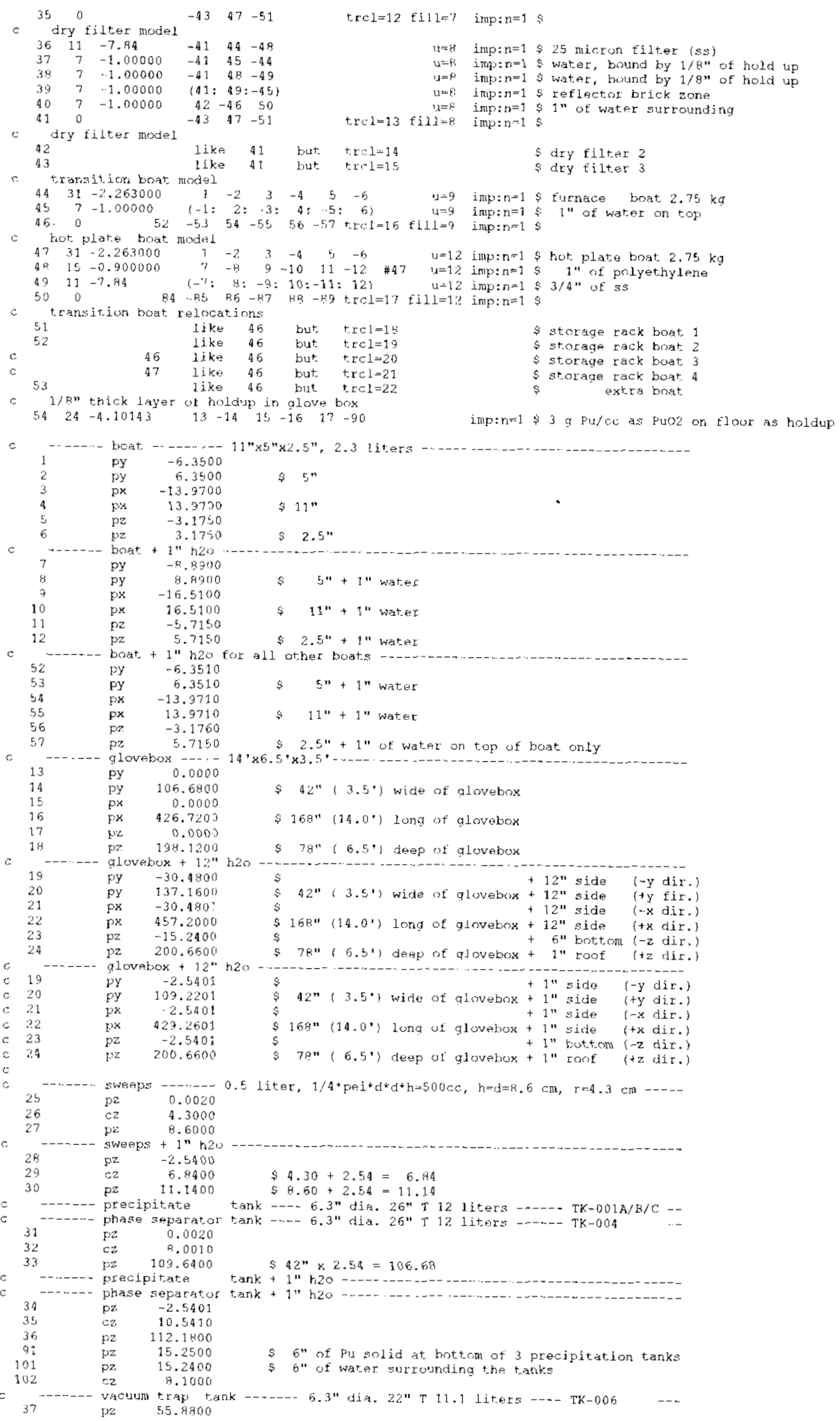




\section{HNF-6537 REV. 0}

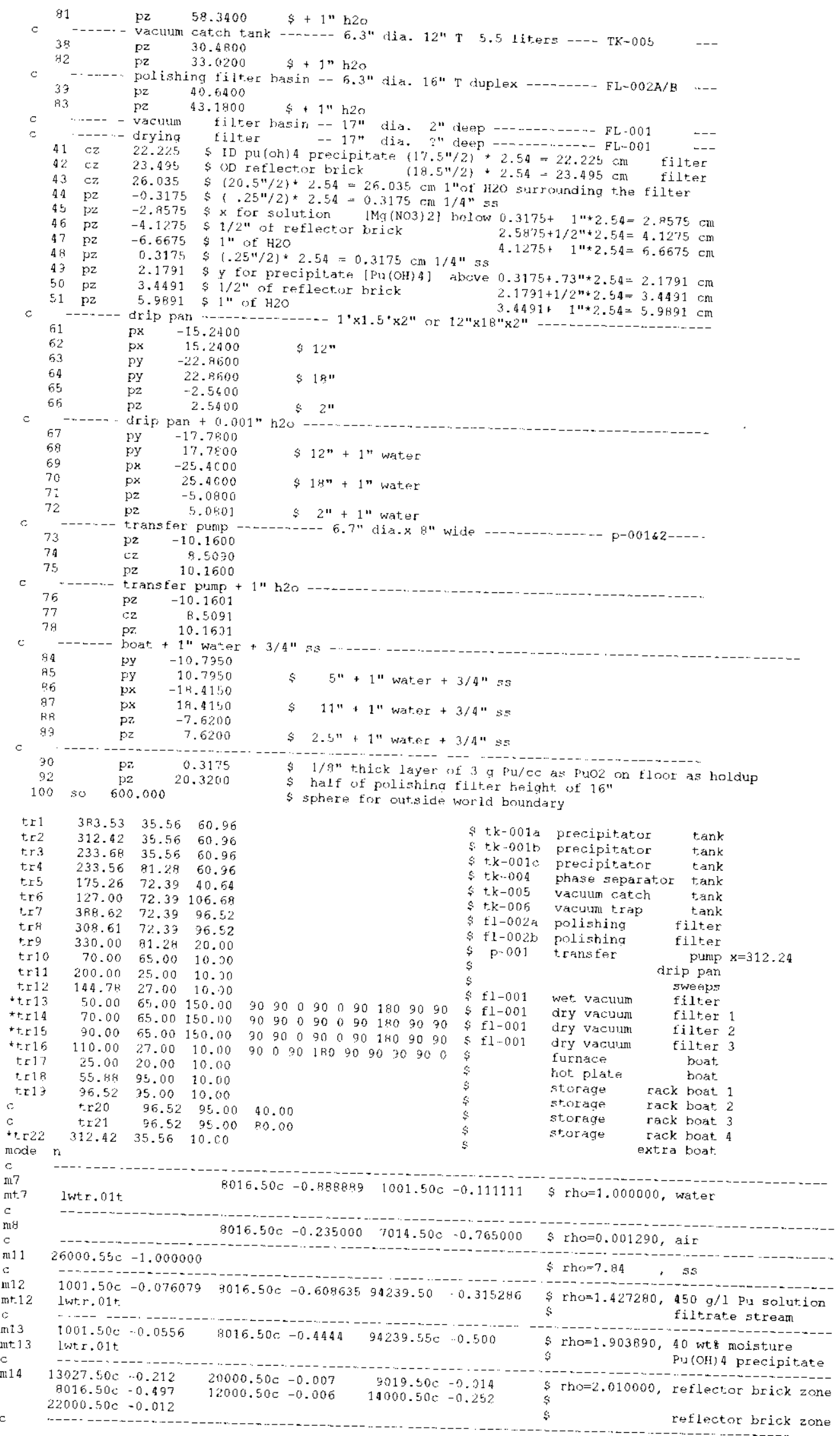


This page cannot be converted.

Please view the native document

for the original page. 
HNF-6537 REV. 0

Caseccl

mạoh alove box 3 criticality, contingency cases, ec1.i

c glovebox model and oltside world

c $250 \mathrm{~g} / \mathrm{L}$ pu(NO3) 4 in precipitator tanks with $6 "$ of PuO2 solids at $3 \mathrm{~g} / \mathrm{ce}$ in bot.ton

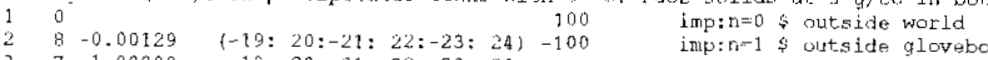

$7-1.00000 \quad 19-20 \quad 21-22=23-24$

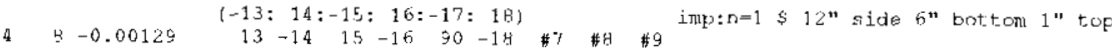

\#5 \#23 \#16

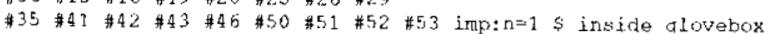

c tank nocle $1,\left(P_{1}\right) \quad 6.3$ " dia. $36.0 " \mathrm{~T} / \mathrm{T}, 20$ liters capacity, 12 liter for normal case

$\begin{array}{cccccc}5 & 32,-1.39550 & -33 & -32 & 91 & 1\end{array}$

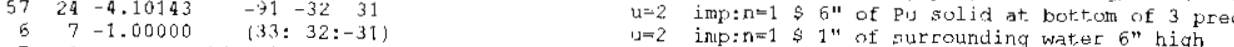

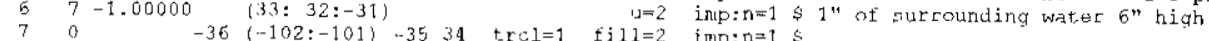

c tank relocations (2)

a like 7 but trcl=2 \$t.k-001b, pre. tank 40 g/L Pu(No3) 4

3 Like 7 but trel=3 $\quad \$$ tk-001c, pre. tank 40 g/L Pu(NO3)4

c $10^{\text {tank nodel, }} 30$ Pu) $-1.001000 \quad-33-32.31$ dia. $35.0 " \mathrm{~T} / \mathrm{T}, 20$ lit.ers

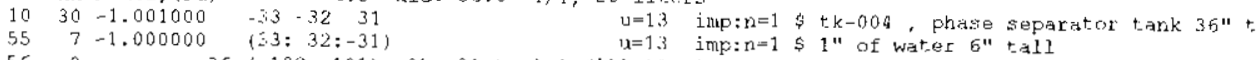

$560 \quad-36 \quad(\cdots 102 ;-101\}-3 t, 34$ trol=4 fill:-13 ilnp:n=1 $\$ 1$ g/L Pu metal, $h / x=26,517$

c tank modei, (Pu) 6.3" dia. 12.0" T/T, 5.5 liters

$1130-1.001000 \quad-38-32 \quad 31 \quad u=10$ imp:ri=1 \& tk-00s, vacuun cattch tăk $12 " t$

$127-1.000000 \quad(38: 32:-31)$

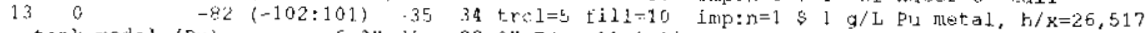

tank model, (Pu) 6.3" dia. 22.0" T/T, 11.1 liters

$1430-1.001000 \quad-37-32 \quad 31 \quad u=11$ imp:n=1 $\$$ t $k-006$, vacuun trap tank 22" $t$

$157-1.000000 \quad(37: 32:-31) \quad$ ul 11 imp:n=1 $\$ 1$ " water 6" tall

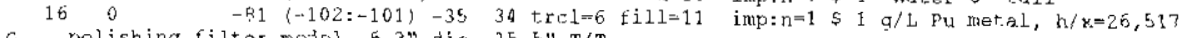

polishing filter mojel, 6. 3" diz. $25.5 " \mathrm{~T} / \mathrm{T}$

$\begin{array}{llllll}17 & 30 & -1.001000 & -39 & -32 & 92\end{array}$

$59 \quad 30-1.001000 \quad-92-32 \quad 31$

$187-1.000000$ (33: $32:-31)$

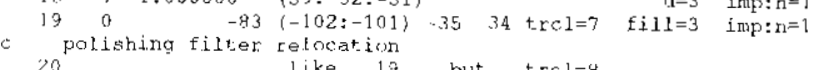

bilt $\operatorname{trcl}=8$

$21 \begin{array}{ccc}30-1.001000 \quad-75 & -74 \quad 73\end{array}$

$22.7-1.000000 \quad(75: 74:-73)$

$230-75-77 \quad 75$

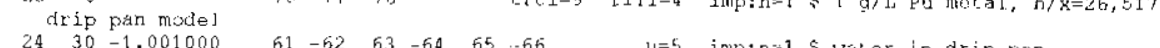

$25 \quad 7-1.000000 \quad(-61: 62:-63: 64:-65: 65 \quad$ b $\quad 1=5$ inp: $n=1$ s water in drip pan

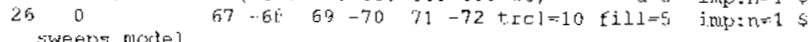

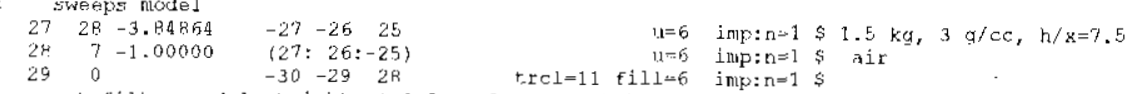

c wet, filter rodel, height, of $2.5 \mathrm{~kg} \mathrm{Pul}$ and $2.5 \mathrm{~kg}$ water $=0.5663 "$

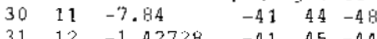

$\begin{array}{llllll}31 & 12 & -1.42728 & -41 & 45 & -44 \\ 32 & 27 & -1.90349 & -41 & 49 & -49\end{array}$

$\begin{array}{llllll}32 & 27 & -1.90349 & -41 & 48 & -49\end{array}$

$34 \quad 7-1.00000 \quad 42-4650$

dry fizter modes

$36 \quad 11-7.64$

$\begin{array}{lll}37 & 7 & -1.00000\end{array}$

$307-1.00000$

$\begin{array}{lll}39 & 7 & -1.00000 \\ 40 & 7 & -1.00000\end{array}$

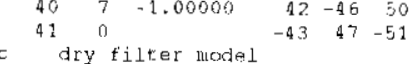

$\begin{array}{lll}43 & 47 & -51\end{array}$

$u=7$ imp: $n=1$ \$2 micron filter (so)

$u=7$ imp: $n=1 \$ 450 \mathrm{~g} / \mathrm{l}$ Pu solution (at $\mathrm{ir}$ for normal cund.

$\mu=7$ imp: $n=1 \$ 2.75 \mathrm{~kg}$ Pu(12 + 2.75 kq water

$u=7$ imp:n=1 \& reflector bick zon

$-4144-49$

$\begin{array}{lll}-41 & 45 & -44\end{array}$

$-41 \quad 4 R-49$

$41: 49:-45$
$42-46: 50$

$u=7$ inp: $n=1$ \$ 1 " of water surrounding

trel $=12$ fill $=7$ imp: $n=1$;

$u=9$ imp:rat $\$ 25$ nicron filter $(s 5)$

$u=9$ inp: $n=1$ water, bound by $1 / 9$ " of hold $1 . \mathrm{p}$

$u=g$ imp: $r=1$ \& water, bound by $1 / B "$ of hold up

$n=$ imp: $n=1$ \& reflector brick zore

tret $=13$ fill $=0$ imp:n=1

$42 . \quad$ like 41 but trol-14 \$dry filter 2

transition boat like 41 but trel-1s

S dry filter 3

$44 \quad 31-2.263000 \quad 1 \quad-2 \quad 3-4 \quad 5-6$

1 $-6=\overline{9}$ inp: $n=1 \$$ furnace boat $2.75 \mathrm{~kg}$

$457-1.00000 \quad(-1: 2:-3: 4:-5: 6) \quad u=9$ inp:n=1 $\$ 1$ " of water on top

c hot plate hoat nodel

c. hot plate hoat nodel

$47 \quad 31-2.263000 \quad 1 \quad-2.03-4 \quad 5 \quad-6 \quad u=12$ imp:n=1 \$ hot plate boat $2.75 x$

$44515-0.900000 \quad 7 \quad-9 \quad 9-10 \quad 11-12$ H47 u=12 imp:n=1 \$ I " of polyethylene

49 11 -7.84 (-7:8: $-9: 10:-11: 12) \quad 1-12$ imp:n-1 $\$ 3 / 4$ " of as

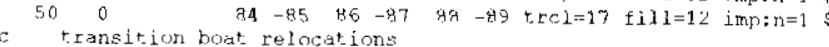

c transition boat relocitions

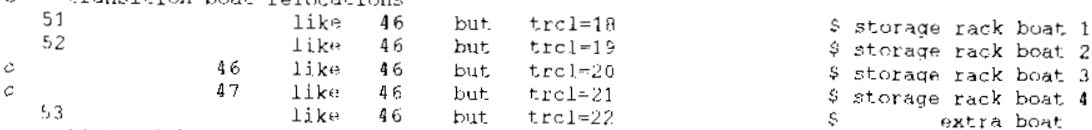

(1/2" thick layer like 46 but trel=20

$5424-4.10143 \quad 13-1415-1617-90$

Imp: $n=1$ \& $3 \mathrm{~g} \mathrm{Pu} / \mathrm{CC}$ axs PuO2 on floor as holdup

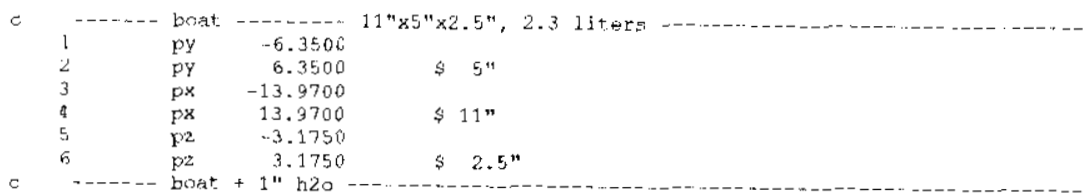




\section{HNF-6537 REV. 0}

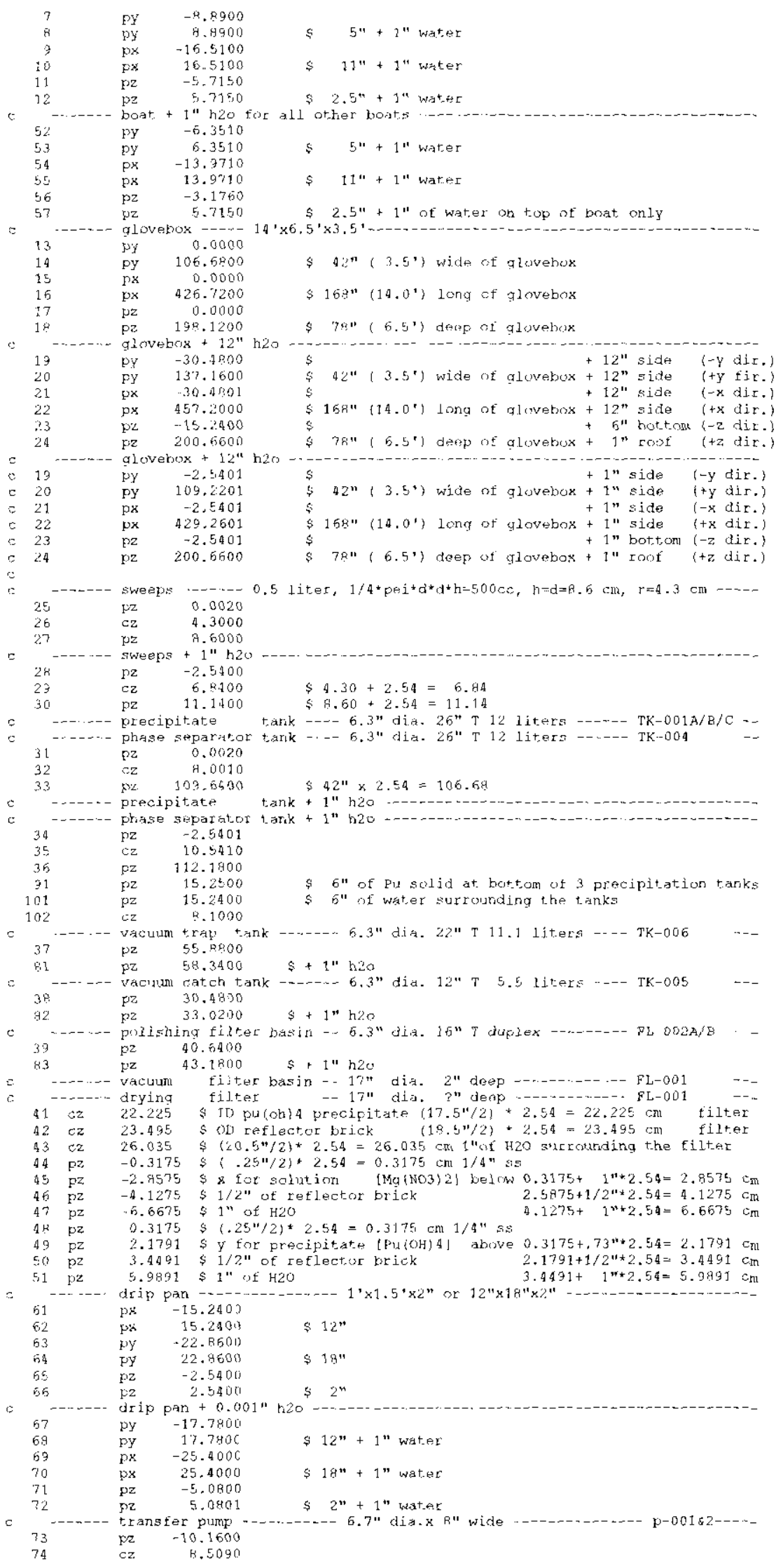




\section{HNF-6537 REV. 0}

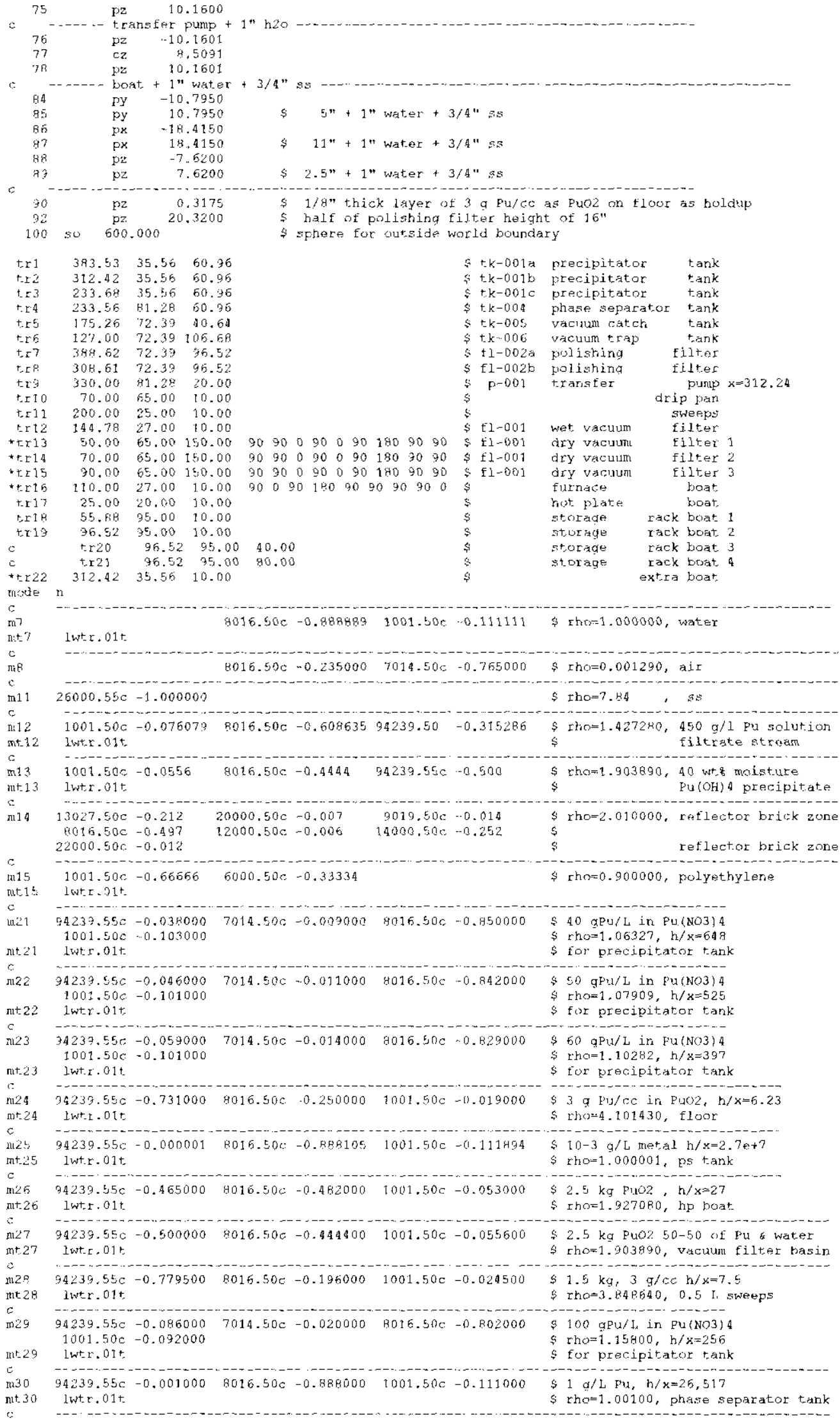




\section{HNF-6537 REV. 0}

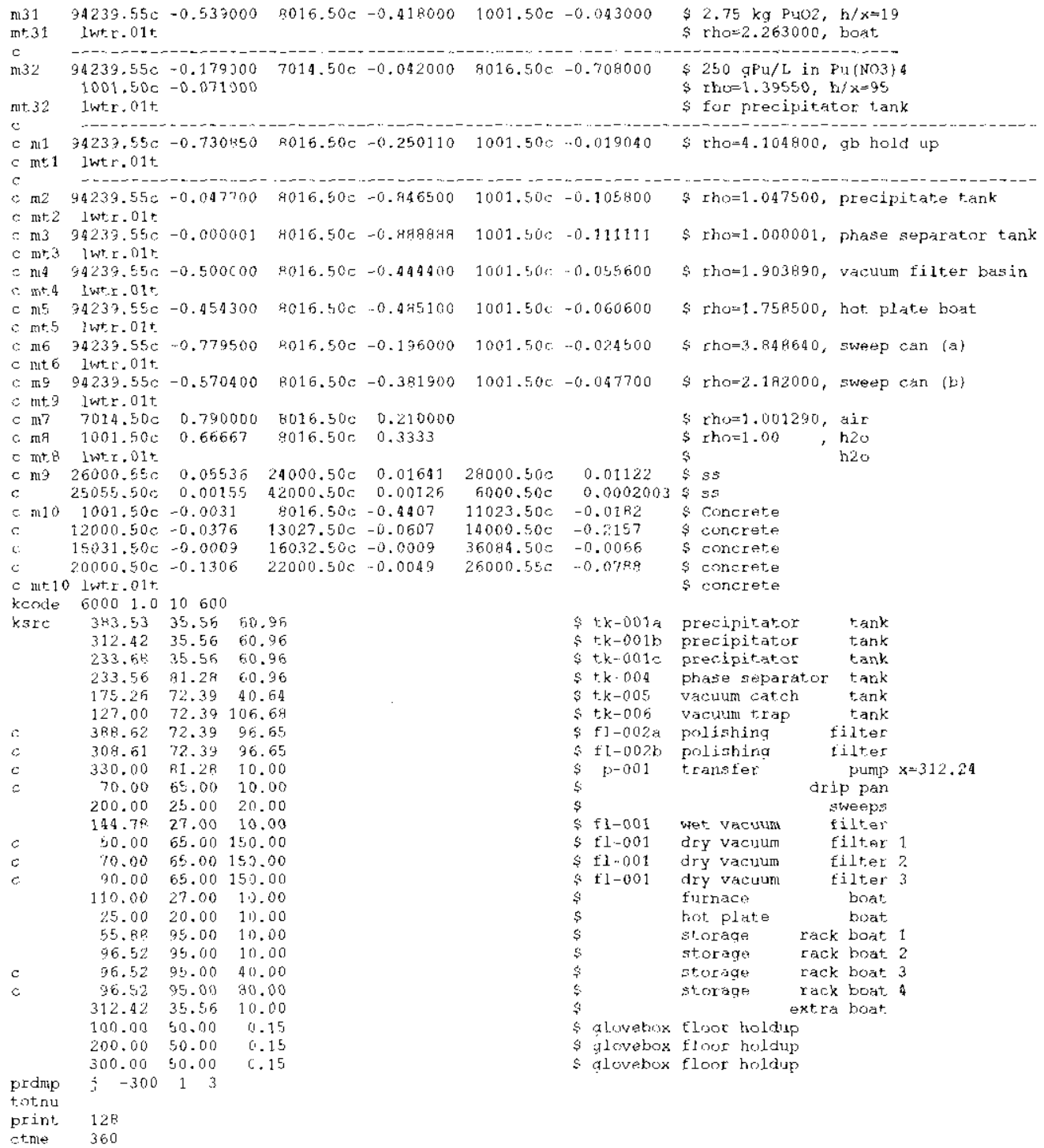

Case ceca

mgoh glove box 3 ctiticality, contingency cases, cc2a.i

glovebox model and outuide world,

c vacuun tank, phase siparator tank, precipitator tank at $65 \mathrm{~g} / \mathrm{L}$ in Pu(NO3) 4 and $36 \mathrm{~L}$

10000 imp:n=0 $\$$ outside world

2 - $-0.00129 \quad(-19: 20:-21: 22:-23: 24)-100$ imp:n=1 \& outside glovebox

$3 \quad 7-1.00000 \quad 19-20=21-22=23-24$

4 9 $-0.00129 \quad 13-14 \quad 15-16 \quad 90-19 \# 3$ \# $\# 9$

imp: $n=1 \$ 12 "$ side $6 "$ bottom $1 "$ top

$\# 56 \# 13 \# 16 \# 19 \# 20 \# 23 \# 26 \# 29$

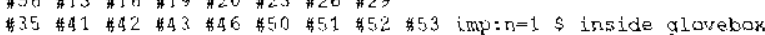

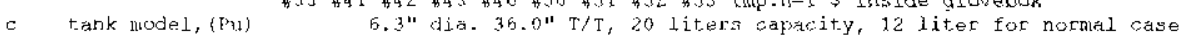

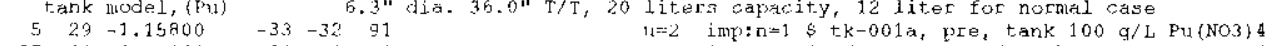

$\begin{array}{rllll}5 & 29 & -1.15 & & \end{array}$

5 $7-1.00000 \quad(33: 32:-31) \quad$ u=2 imp:n=1 $\$ 1$ "of surrounding water b" high

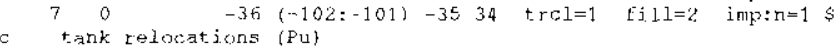

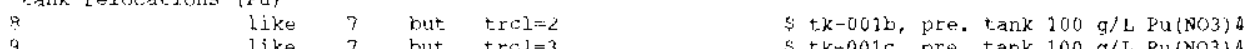

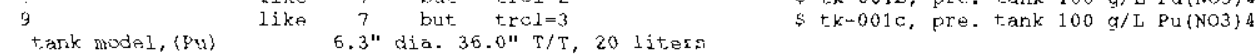

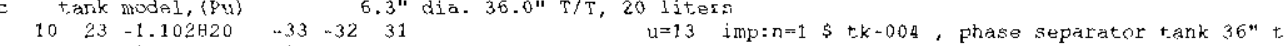

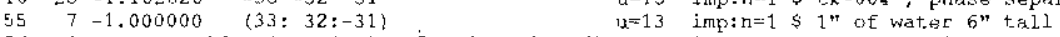

$560 \quad-36(-102:-101)-35$ 34 trel -4 fill=13 imp:n=1 \& 55 g/I $p u$ in pu(No3) $4, h / x=395$

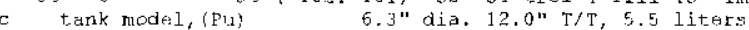

$1123-1.102820 \quad-38-32 \quad 31$ u 10 imp:n=1 s t k-005, vaculn catch tank 12 "

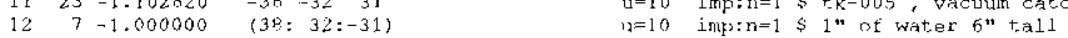

$130 \quad-92(-102: 101)-3 \$ 34 \operatorname{trcl}=5$ fill $=10$ imp: $n=1 \$ 65$ g/L Pu in pu(No3) $4, h / x=395$

c tark nudel, (Pu) $5.3 "$ dia. $22.0 " \mathrm{~T} / \mathrm{T}, 11.1$ litors

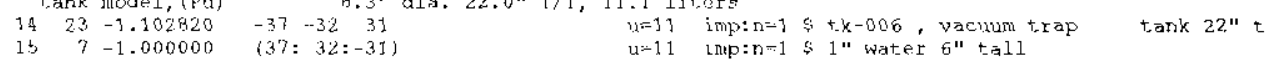




\section{HNF-6537 REV. 0}

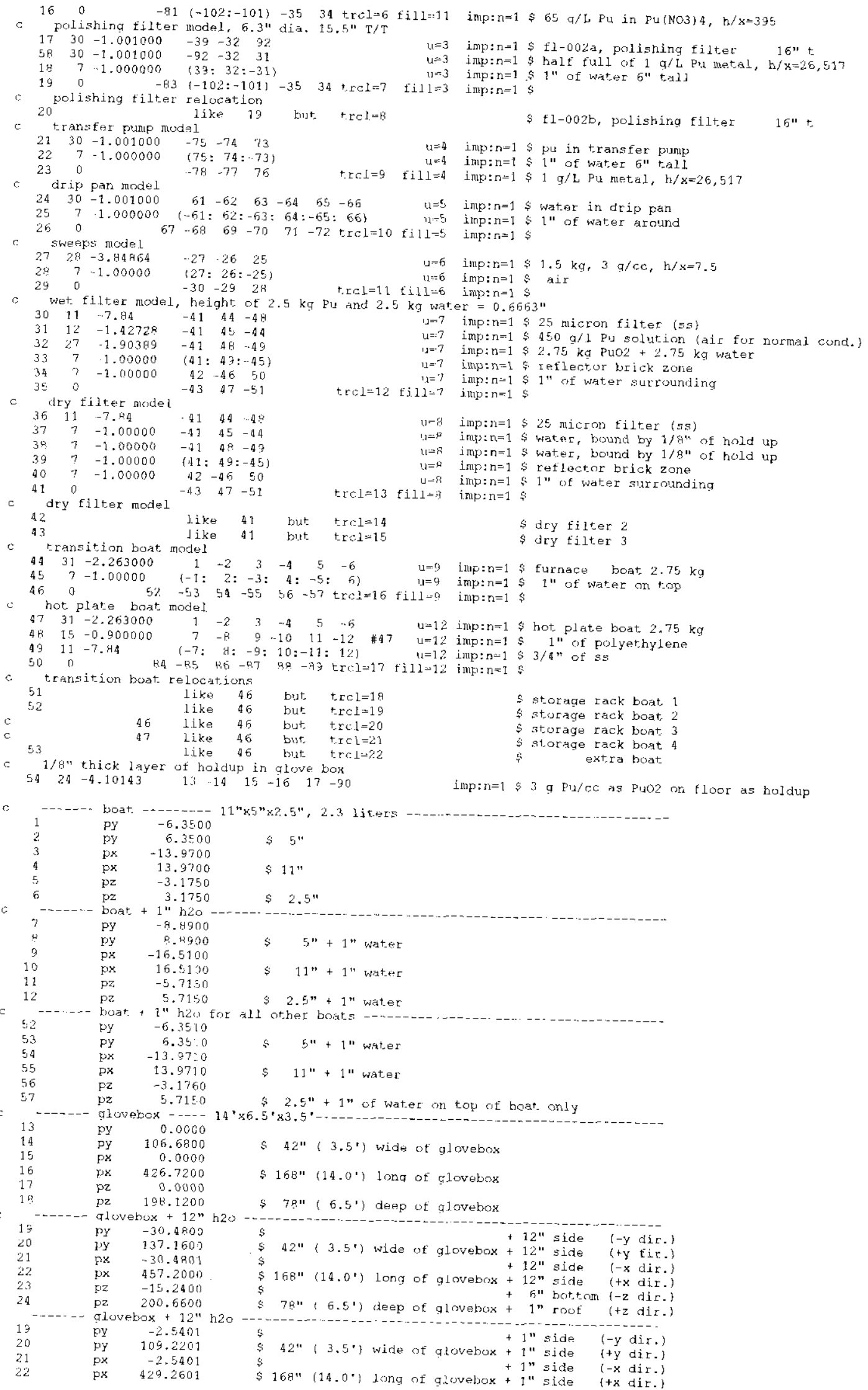


HNF-6537 REV. 0

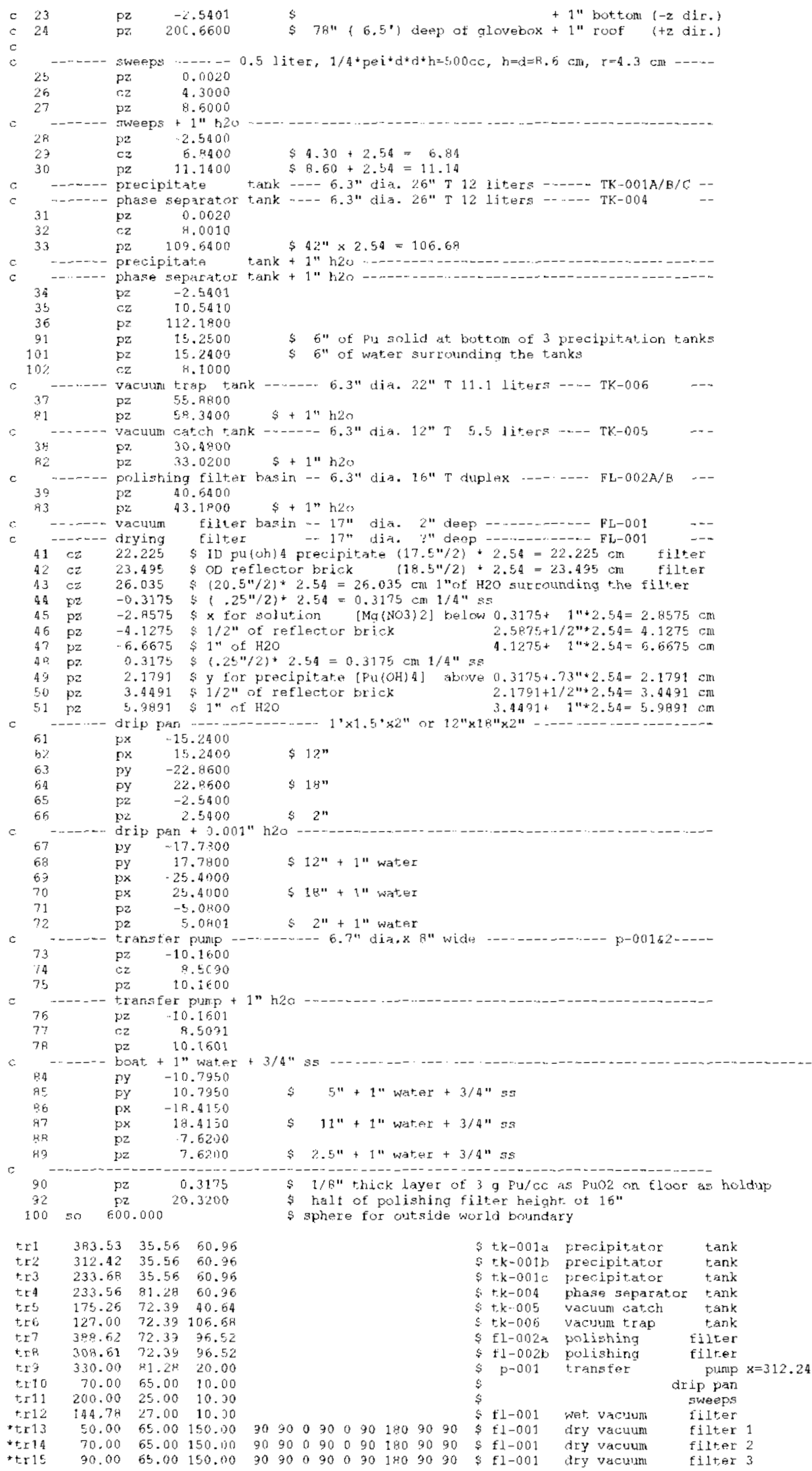




\section{HNF-6537 REV. 0}

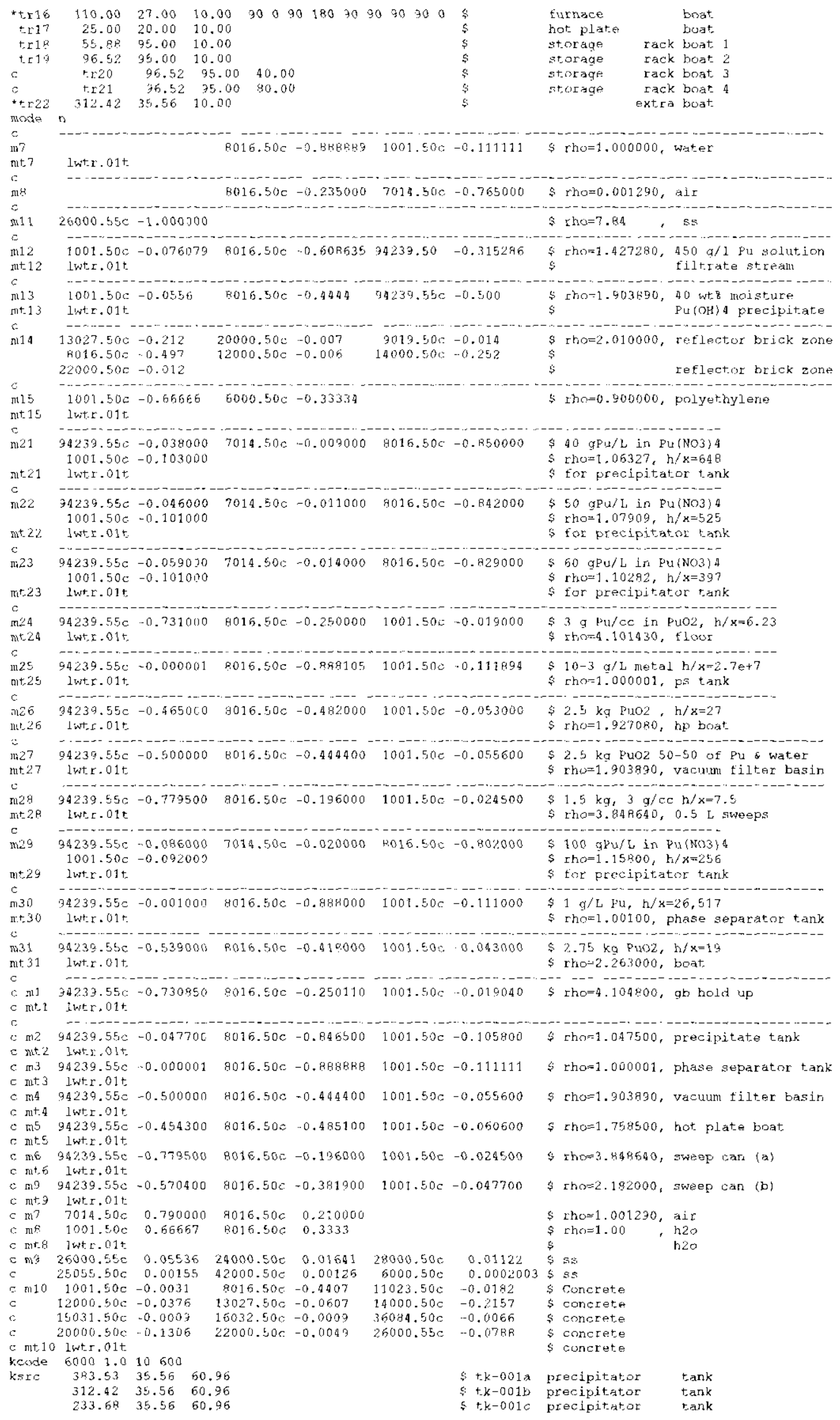




\section{HNF-6537 REV. 0}

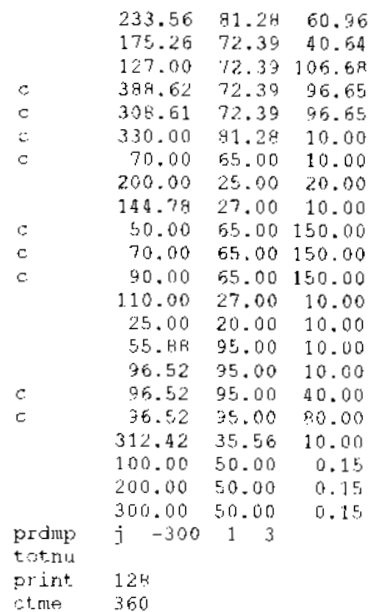

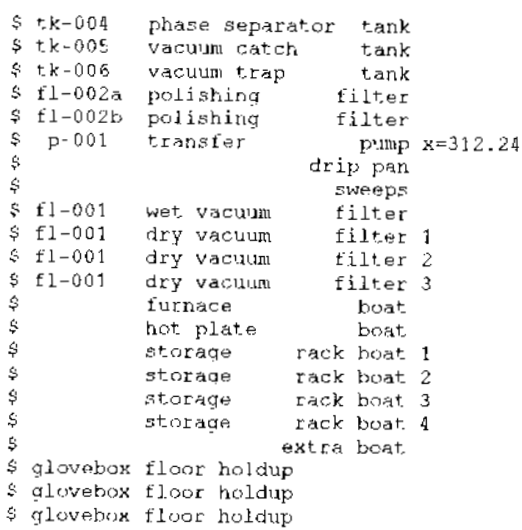

Case cci2b

nlyoh glove box 3 criticality, contingency cases, cozb. c glovebox model and outside world.

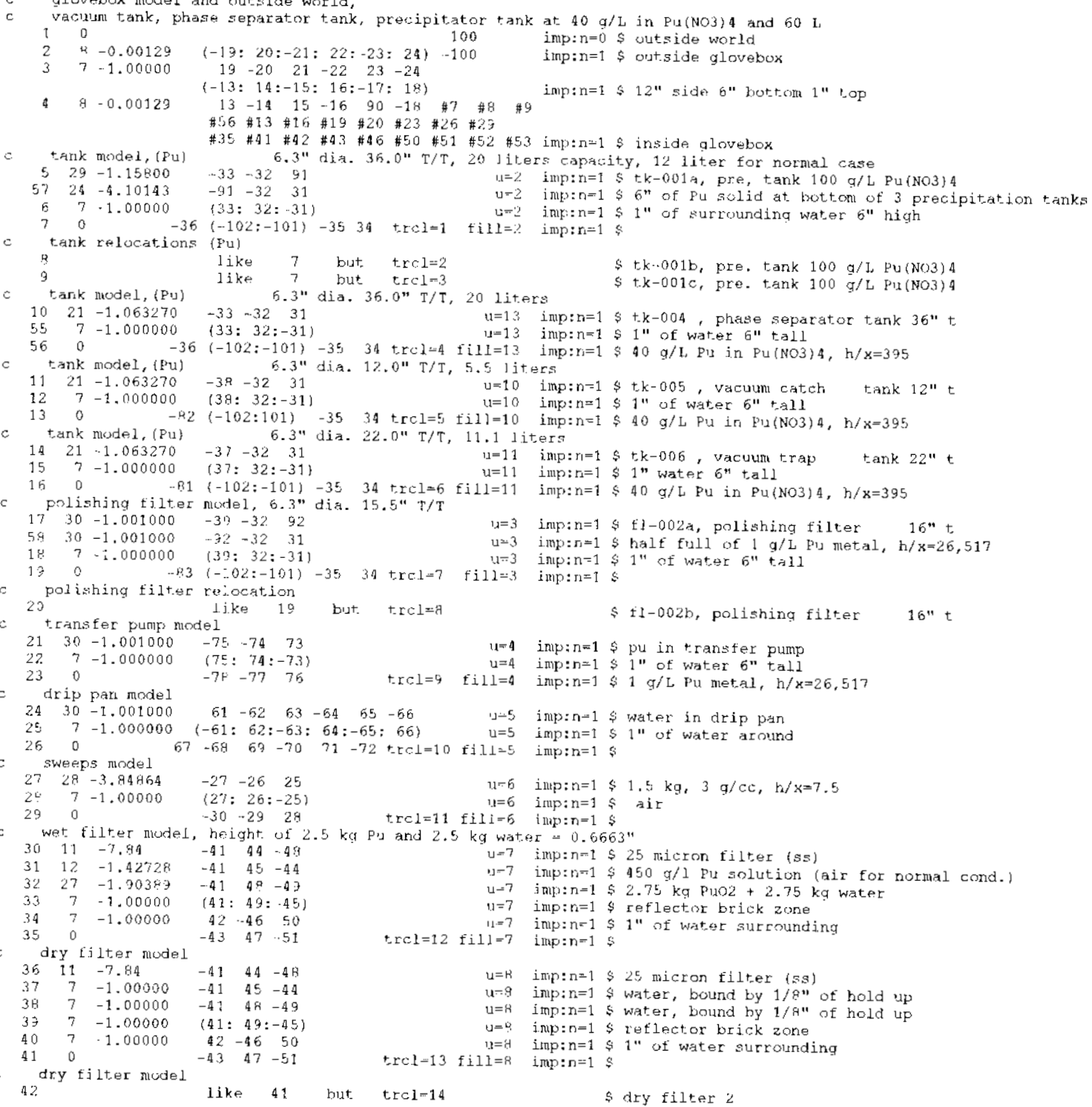




\section{HNF-6537 REV. 0}

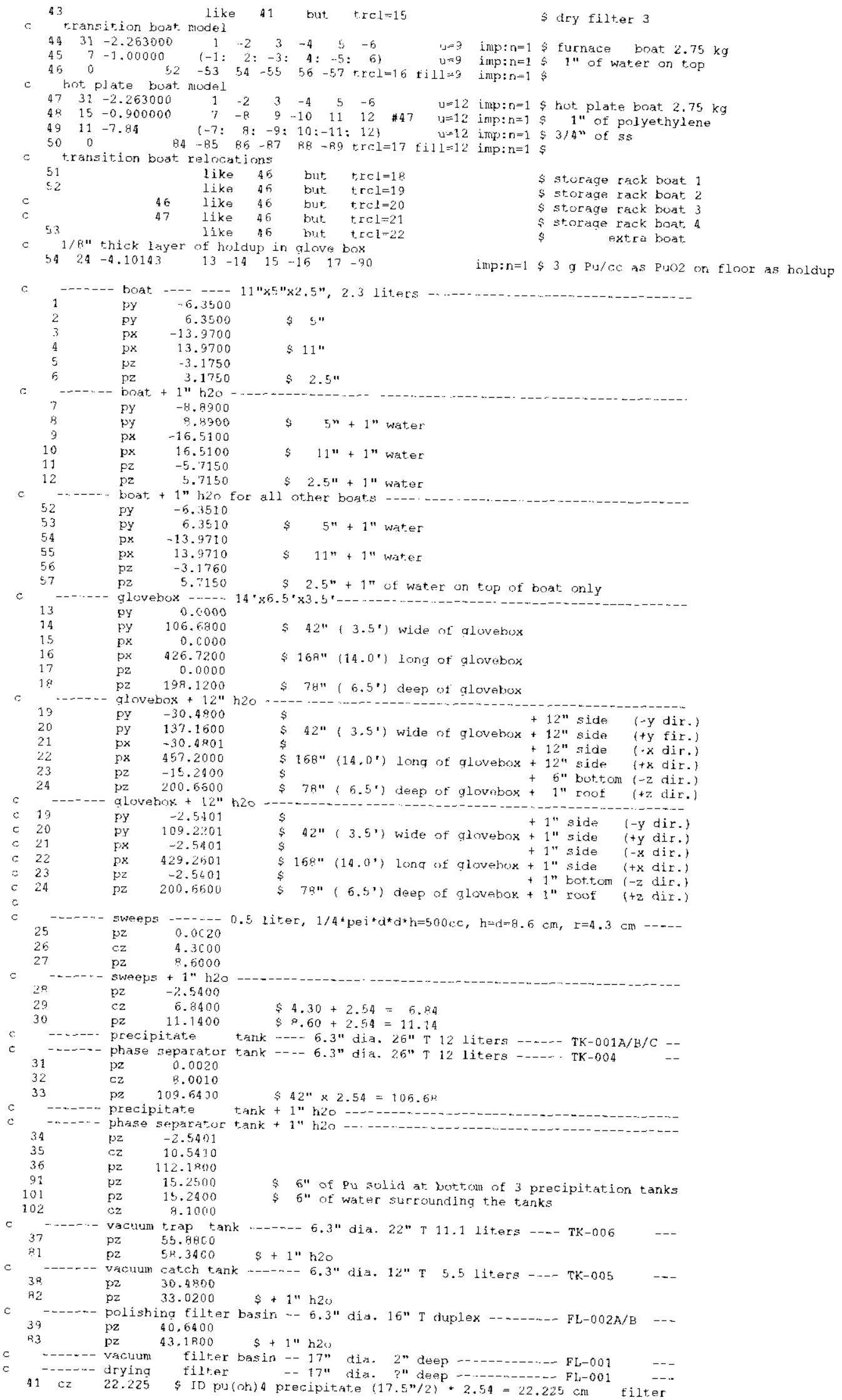




\section{HNF-6537 REV. 0}

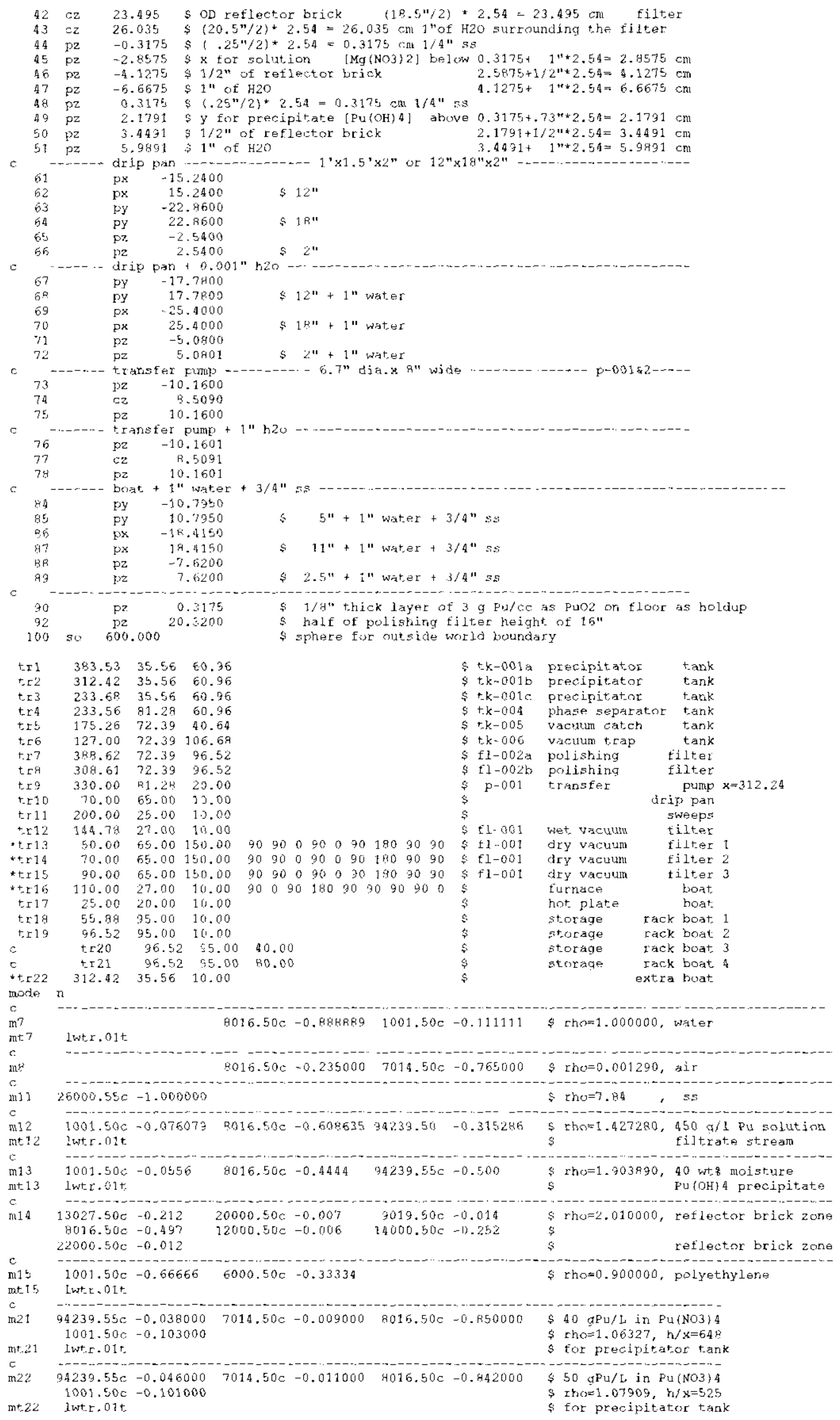




\section{HNF-6537 REV. 0}

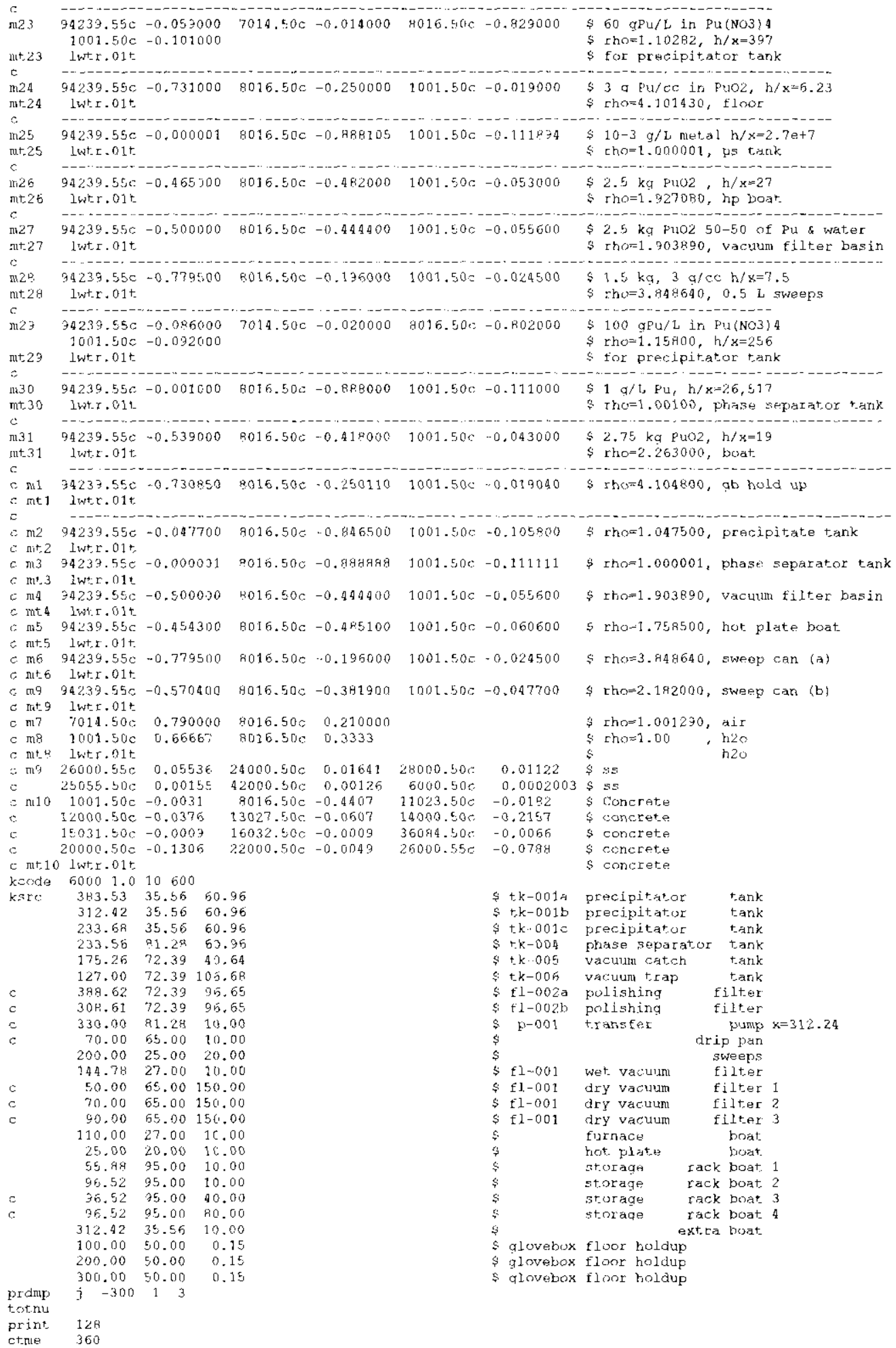

Casecc4

mgoh gluve hux 3 criticality, continqency cases, cc4.j

c glovebox model ard outside world

c extra stacked boat (cell 5.3)

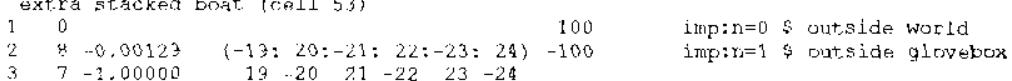




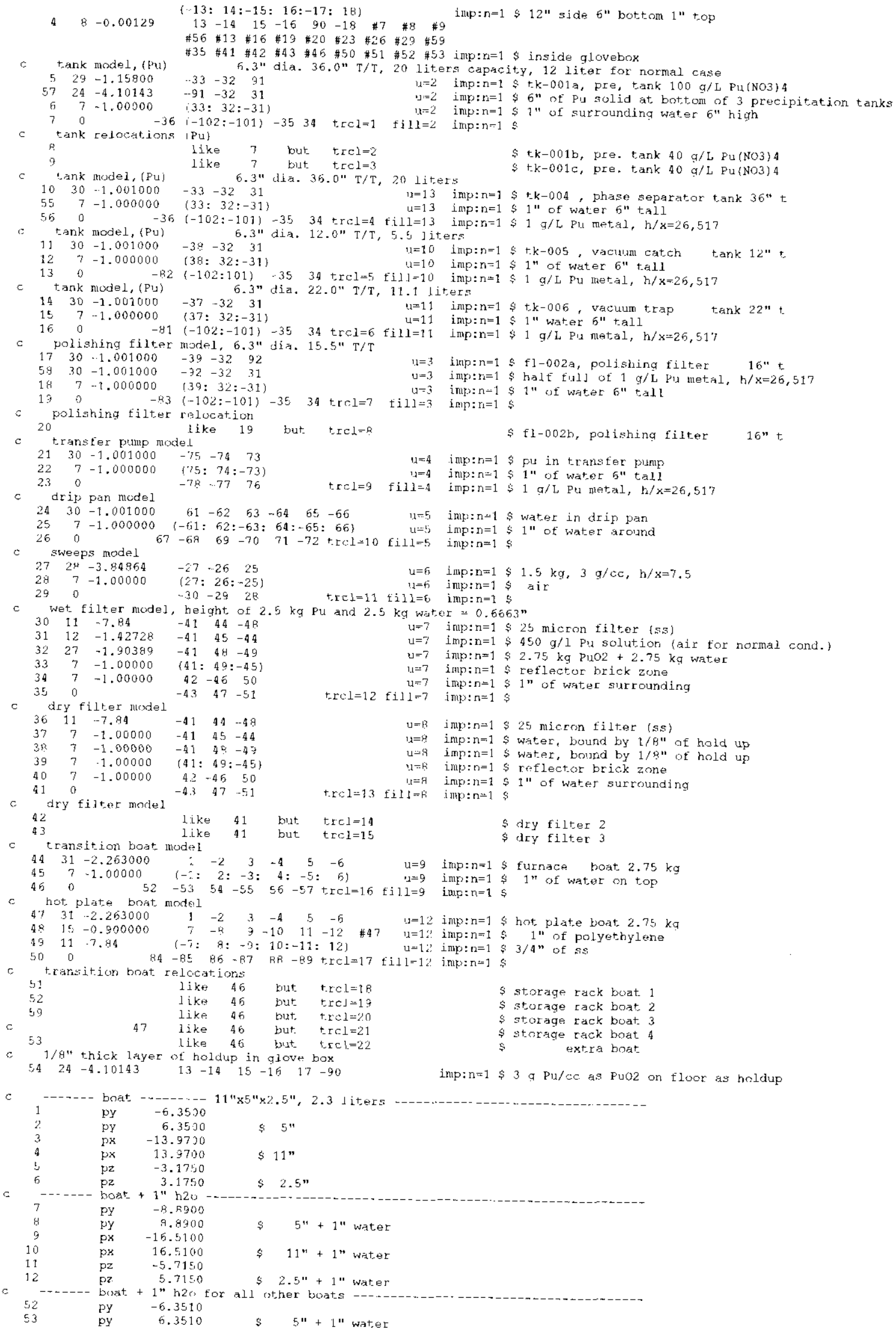




\section{HNF-6537 REV. 0}

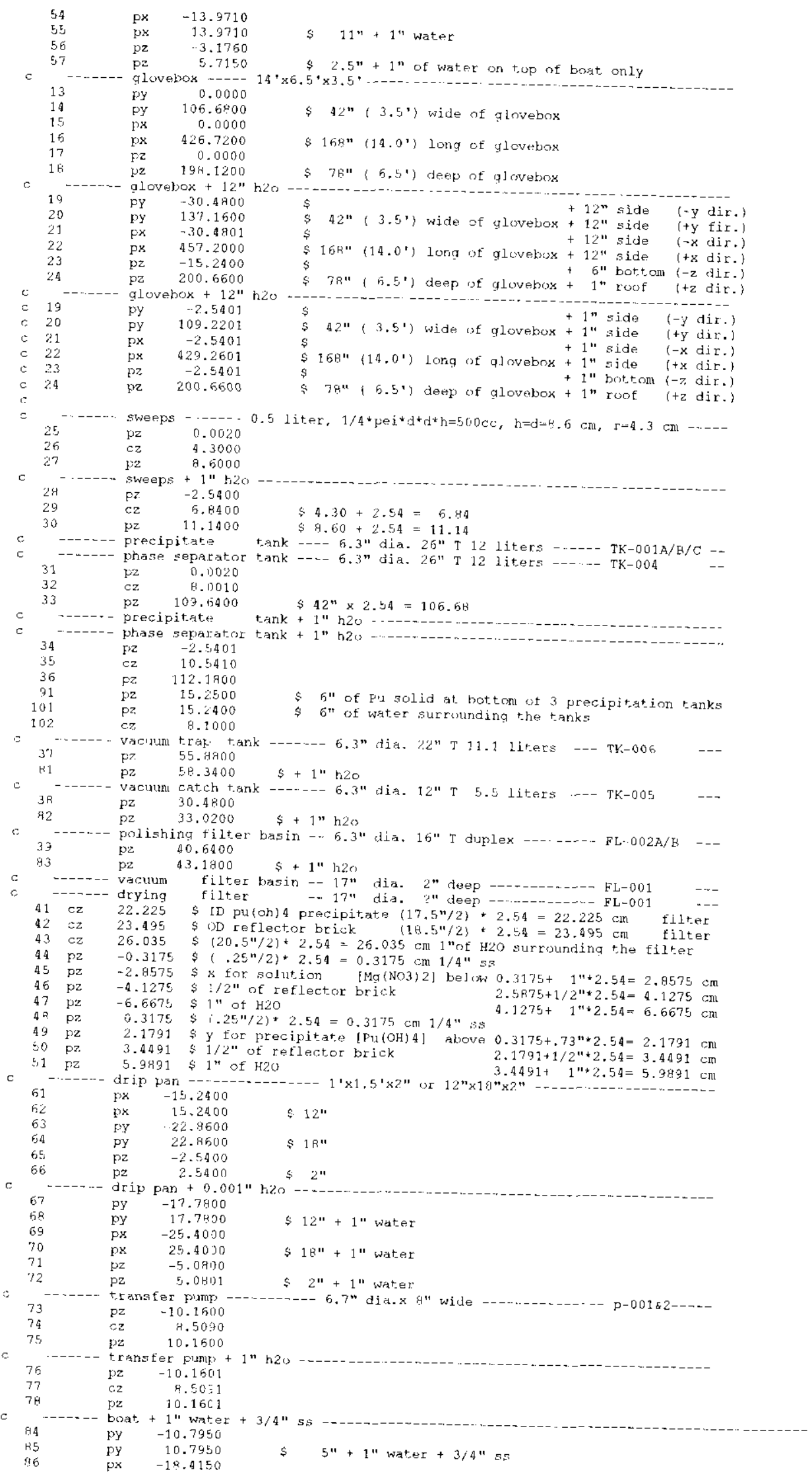


This page cannot be converted.

Please view the native document

for the original page. 


\section{HNF-6537 REV. 0}

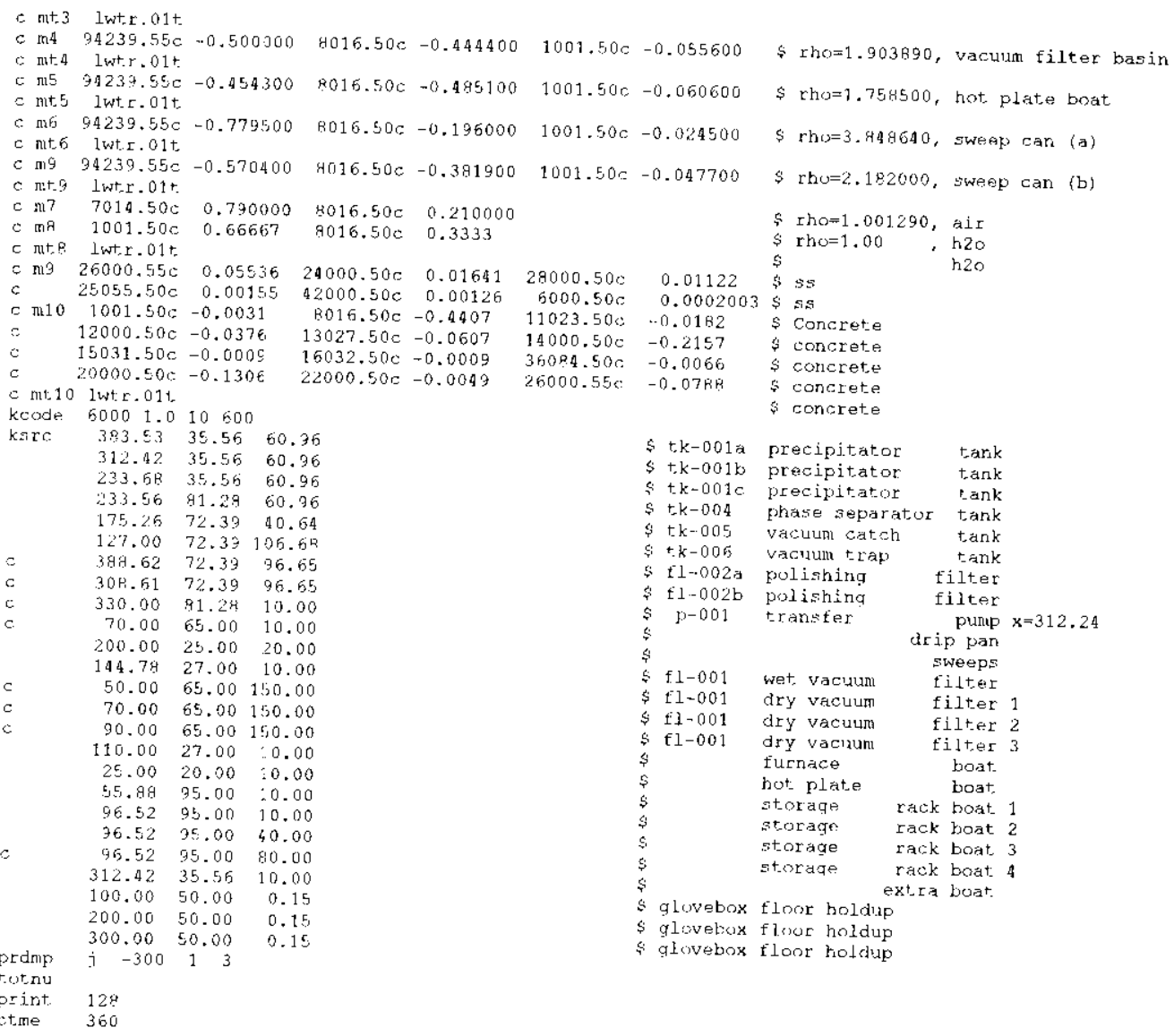

Case $\cos 2$

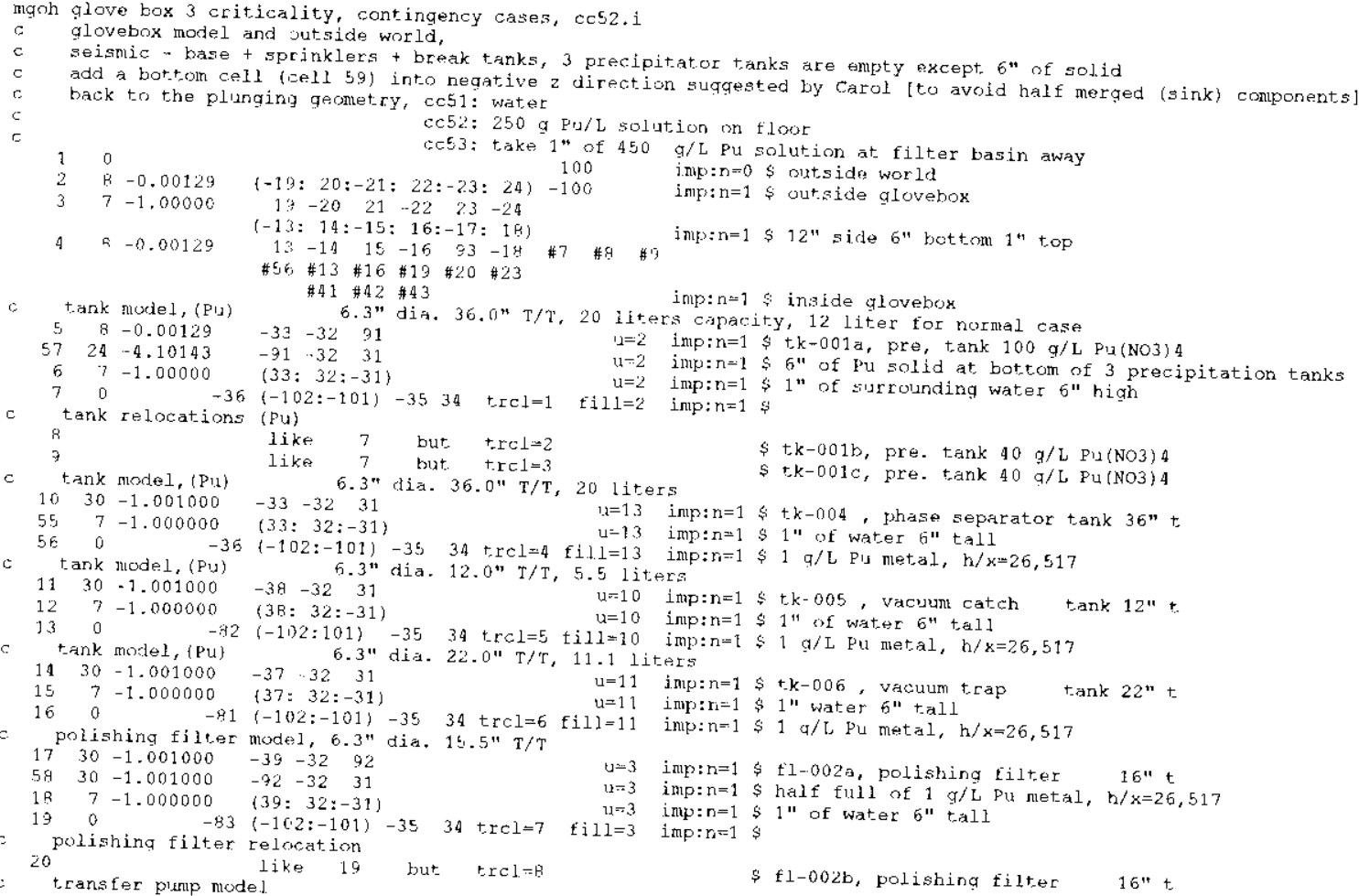


HNF-6537 REV. 0

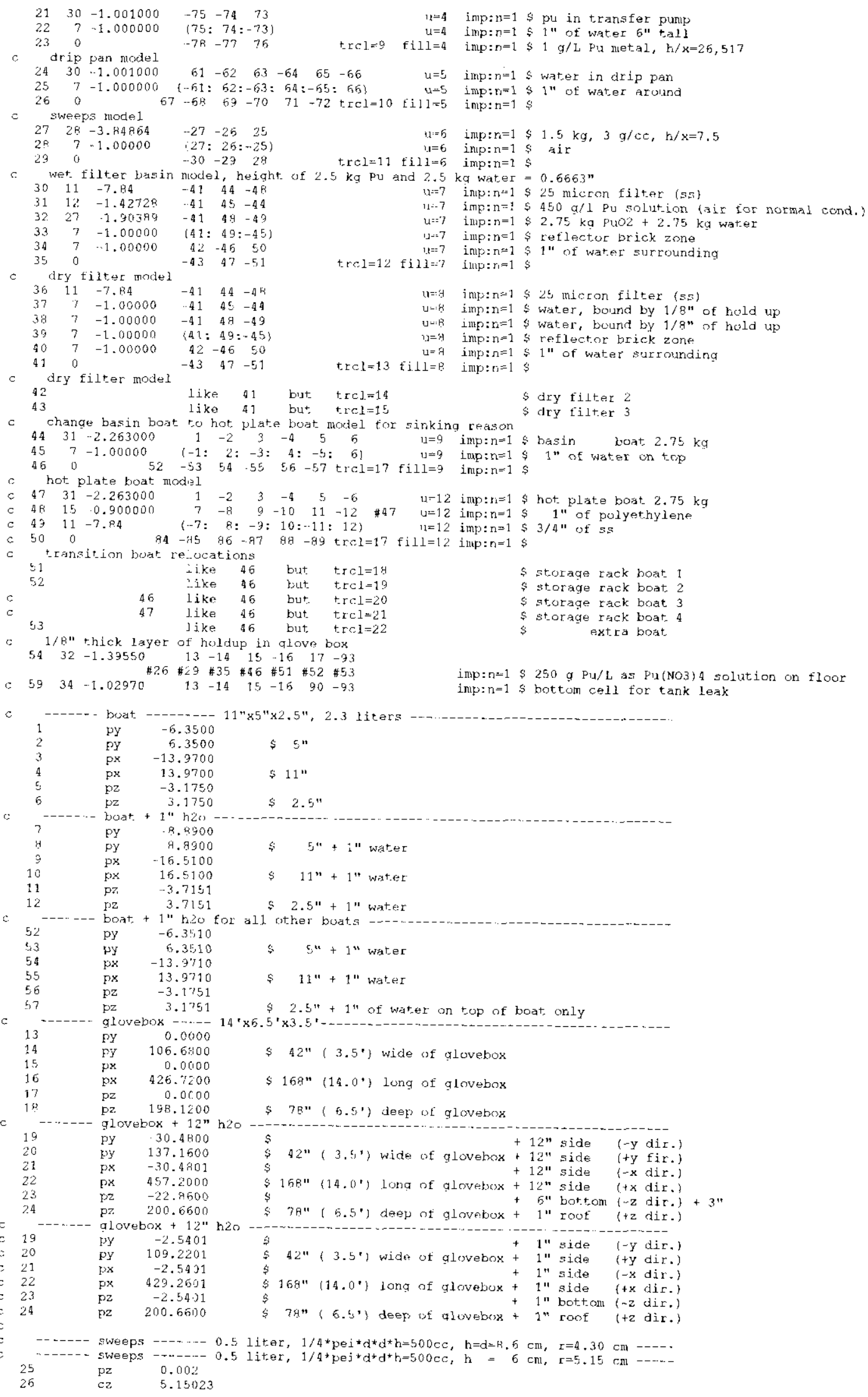


HNF-6537 REV. 0

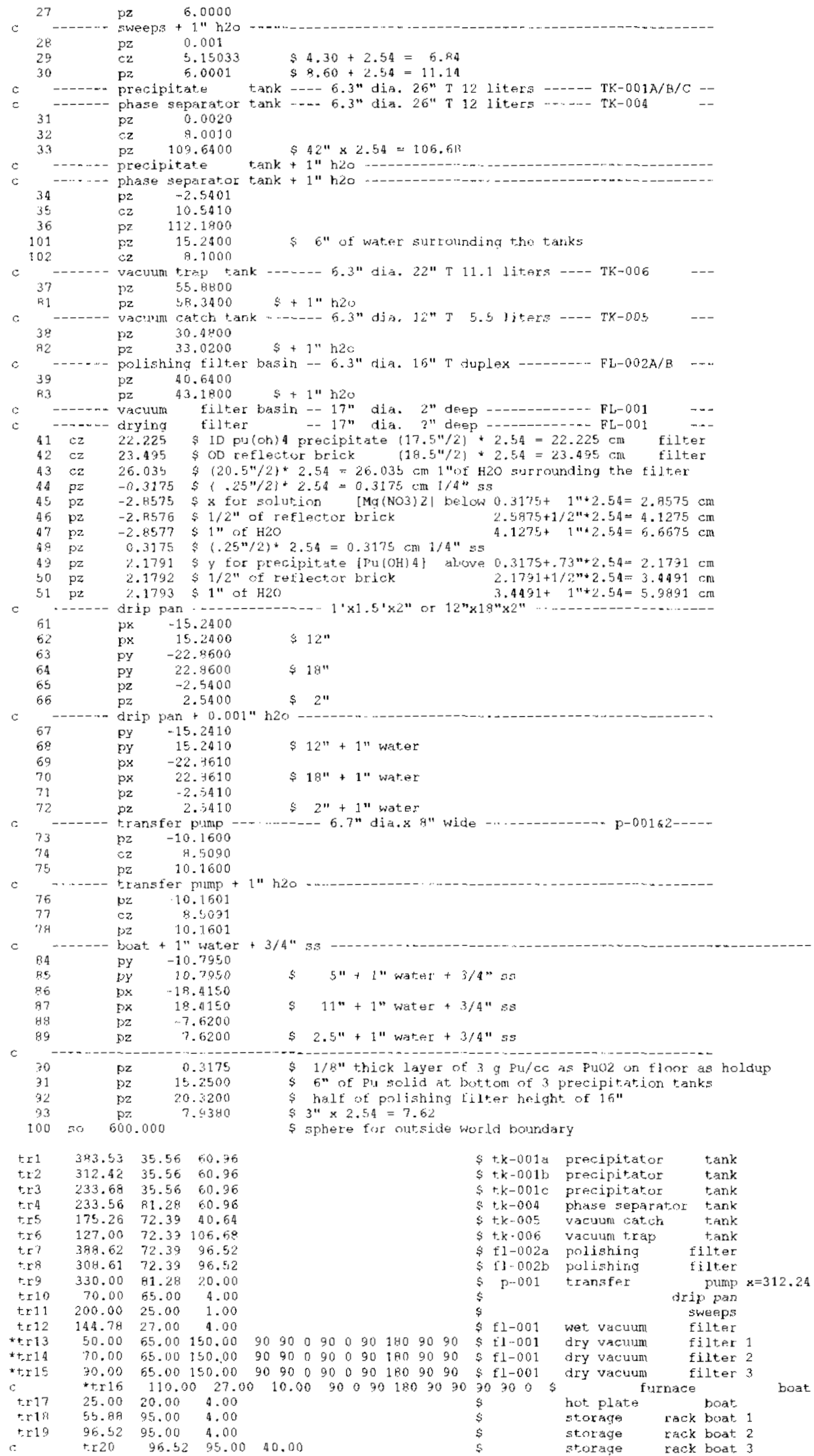




\section{HNF-6537 REV. 0}

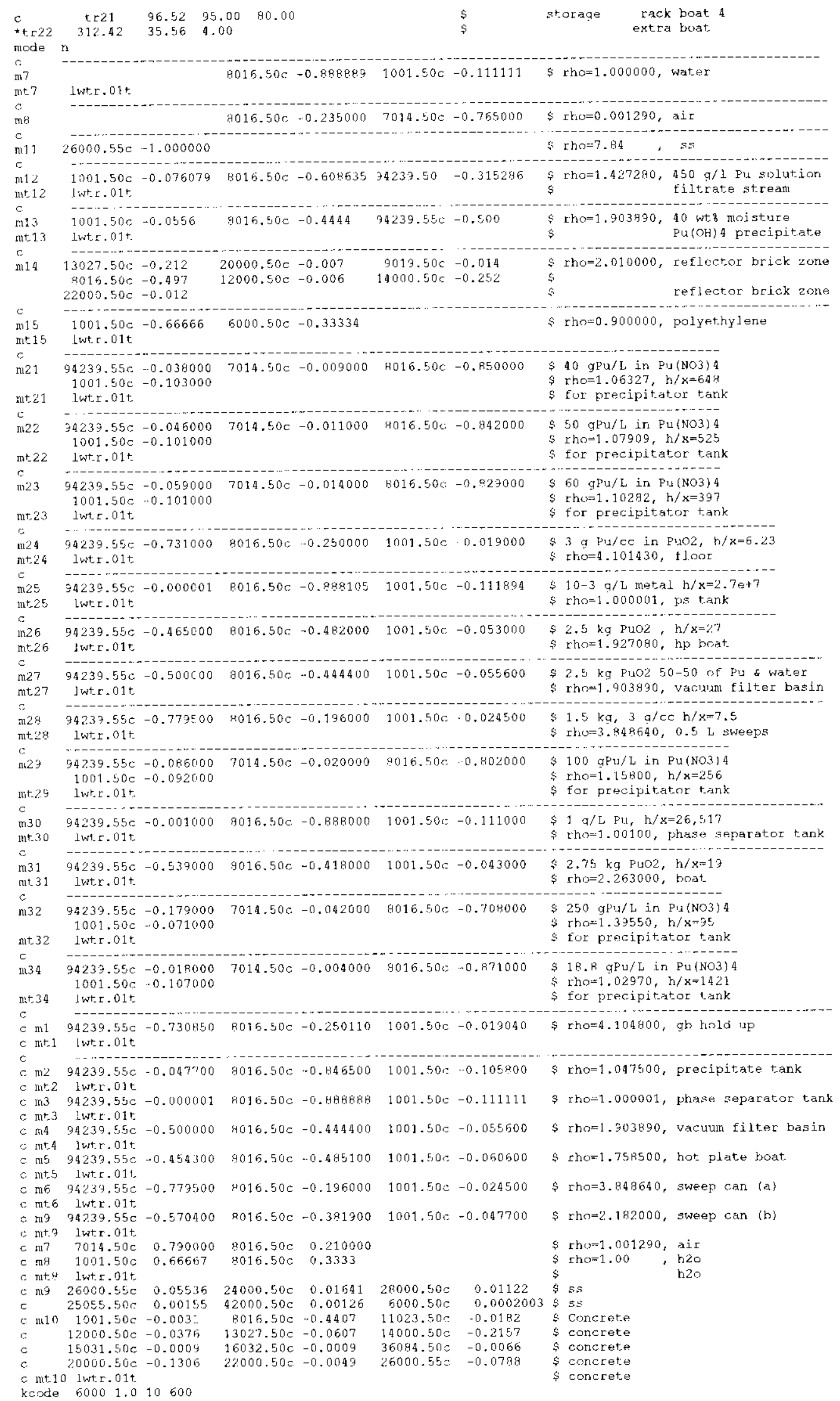




\section{HNF-6537 REV. 0}

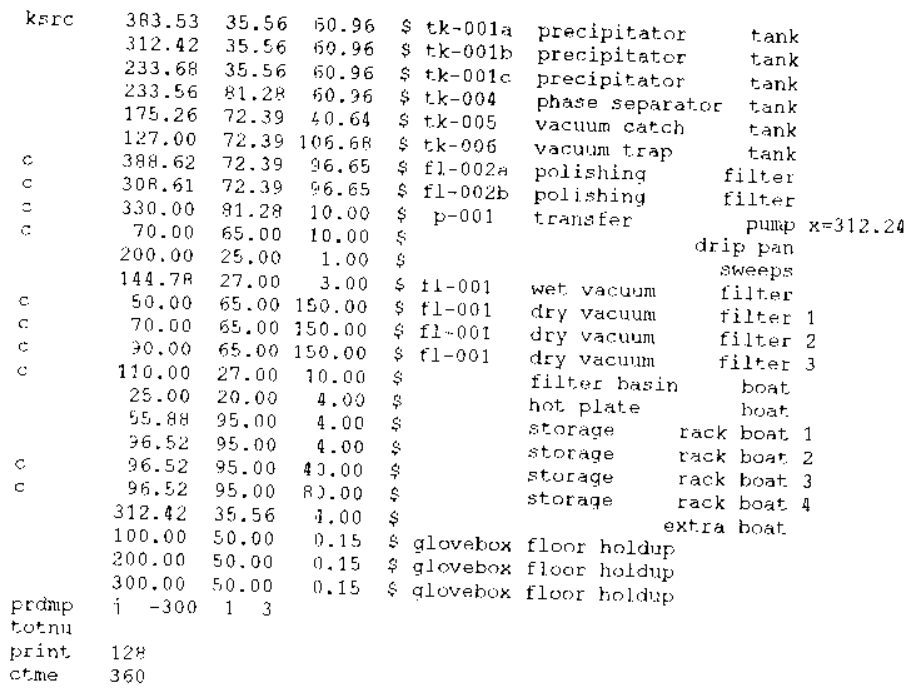

Case ce 7

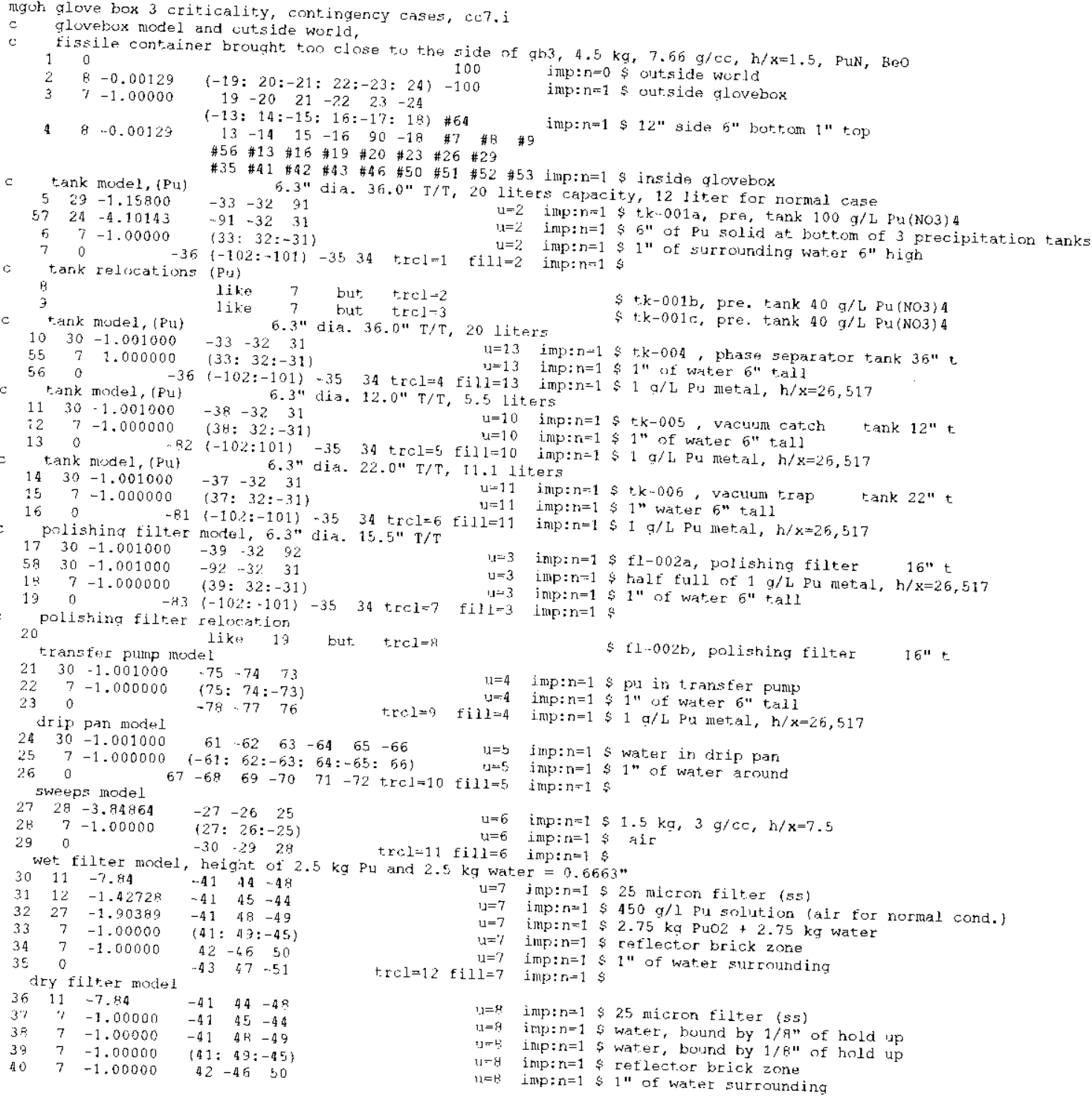




\section{HNF-6537 REV. 0}

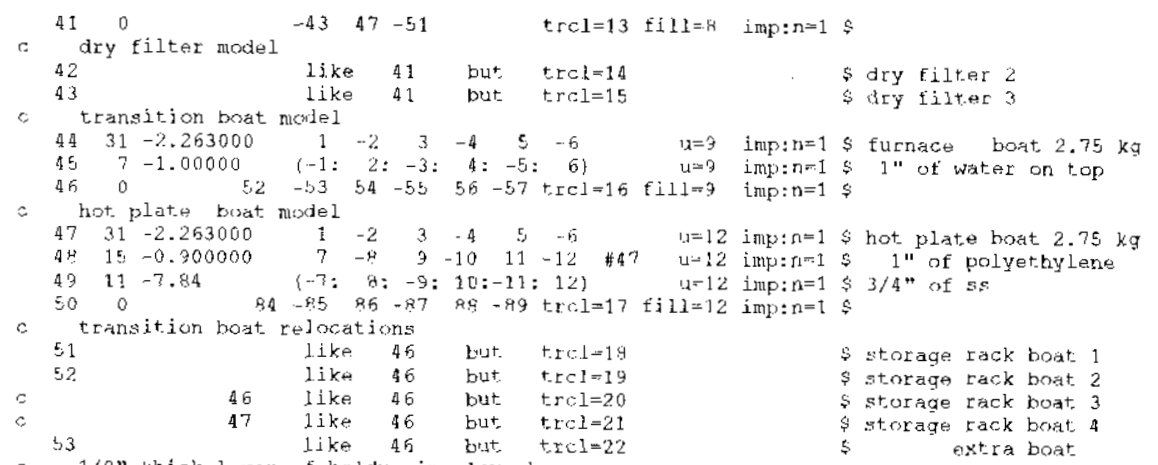

c $1 / 9$ " thick layer of holdup in glove box

$\begin{array}{llllllll}54 & 24 & -4.10143 \quad 13 & -14 & 15 & -16 & 17 & -90\end{array}$

c. $4.5 \mathrm{~kg}$ can model, $7.66 \mathrm{~g} / \mathrm{cc}, \mathrm{h} / \mathrm{x}=1.5$

$61 \quad 35-8.540300-111 \quad 112-119$

$62 \quad 7-1.000000-111 \quad 11 \%-113$

$640-116(-117:-119) \quad 114$ 11t trel=23 fill $1=1$ imp: $n=1$ \& Beo

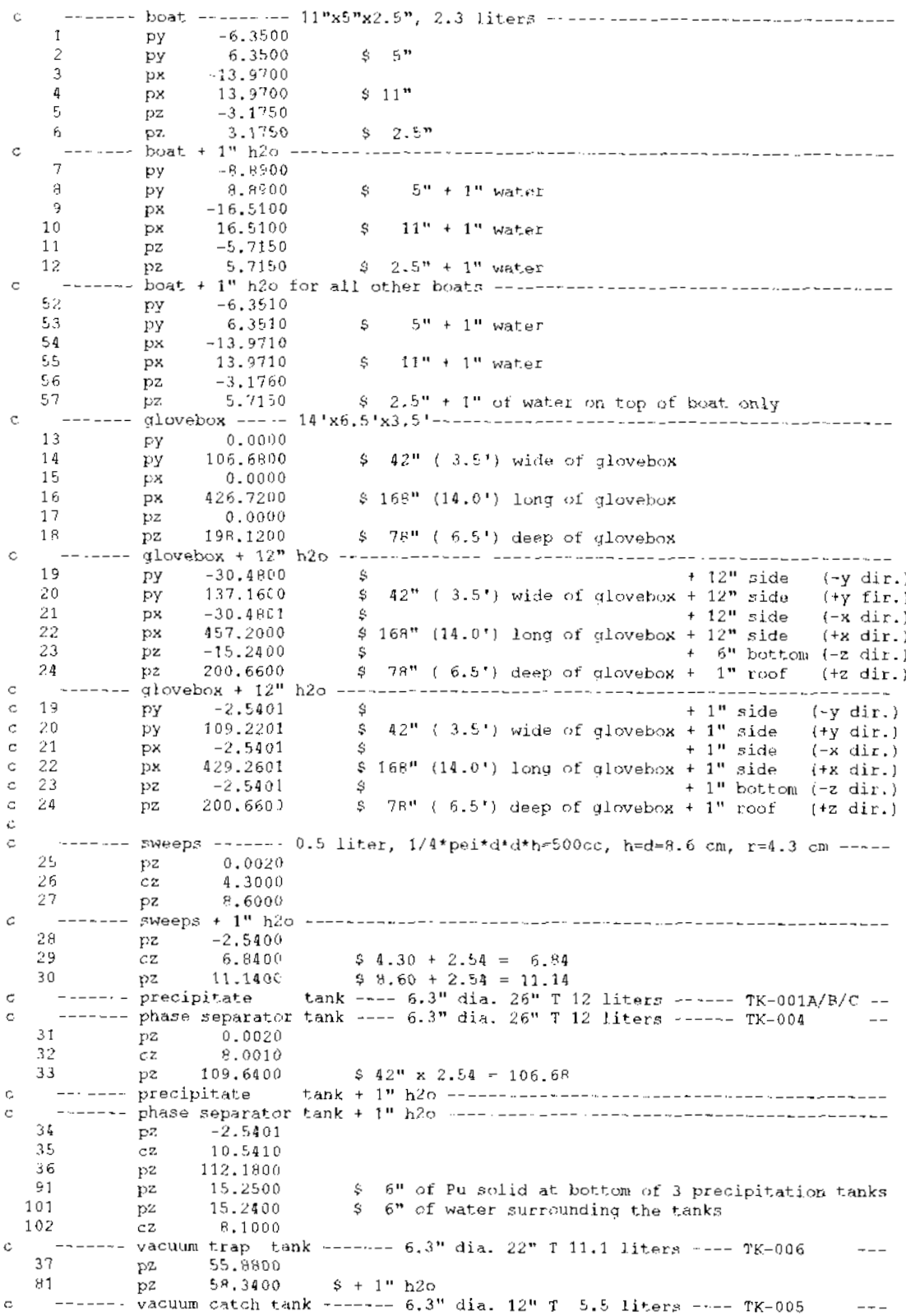




\section{HNF-6537 REV. 0}

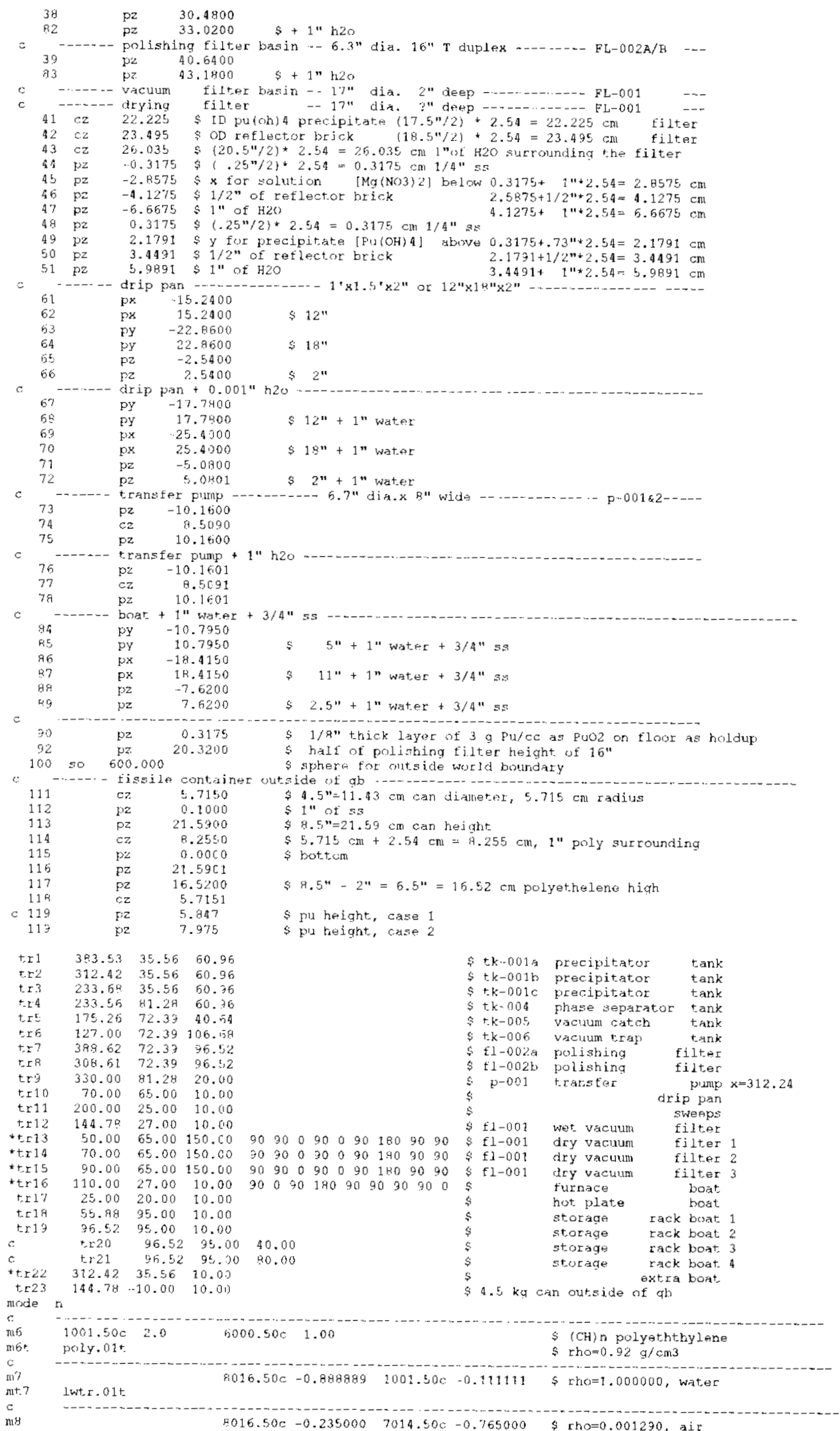


HNF-6537 REV. 0

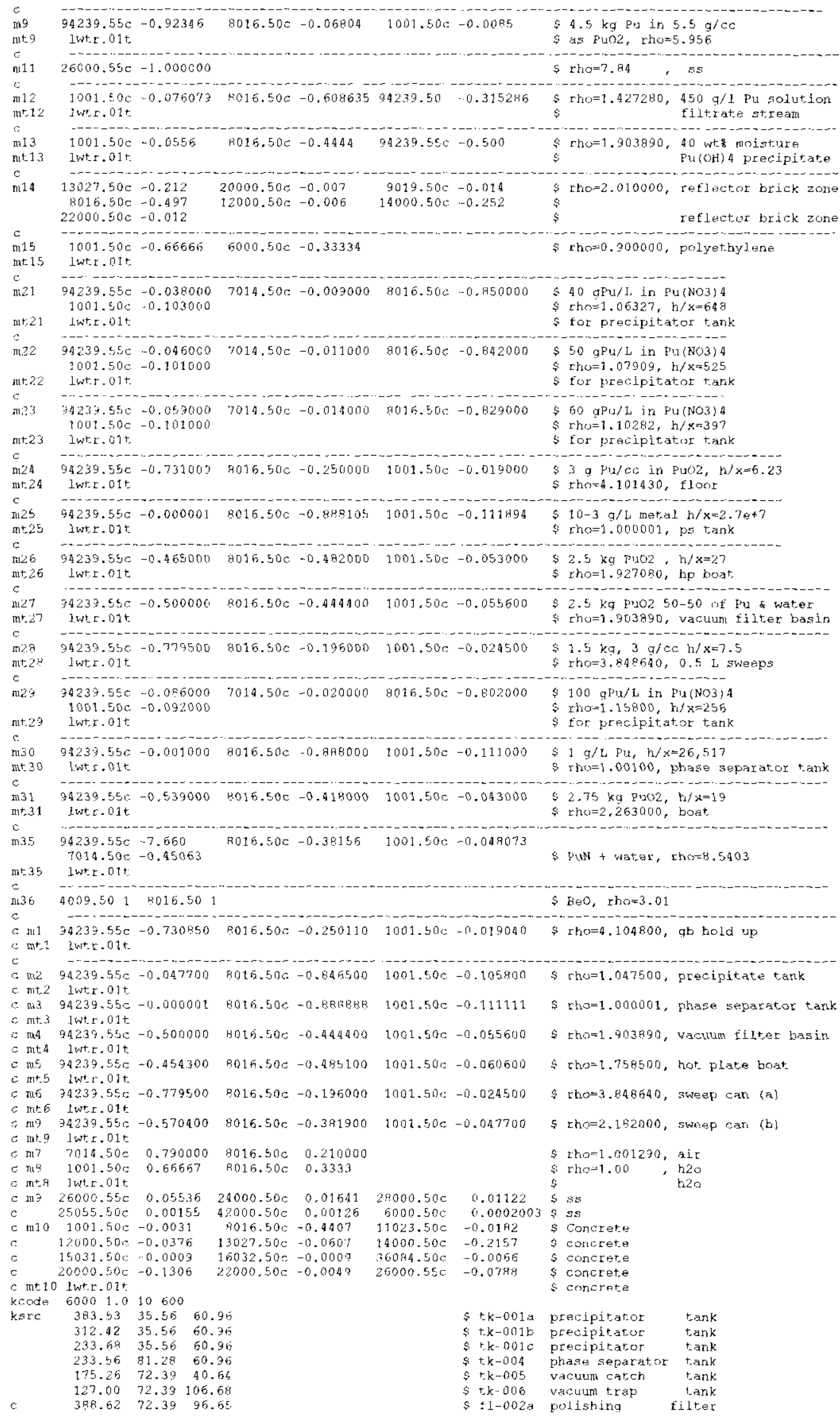


HNF-6537 REV. 0

\begin{tabular}{|c|c|c|c|}
\hline c & 309.61 & 72.39 & 96.65 \\
\hline c & 330.00 & 81.28 & 10.00 \\
\hline \multirow[t]{3}{*}{ c } & 70.00 & 65.00 & 10.00 \\
\hline & 200.00 & 25.00 & 20.00 \\
\hline & 144.78 & 27.00 & 10.00 \\
\hline$c$ & 50.00 & 55.00 & 150.00 \\
\hline$c$ & 70.00 & 65.00 & 150.00 \\
\hline \multirow[t]{5}{*}{ c } & 90.00 & 55.00 & 150.00 \\
\hline & 110.00 & 27.00 & 10.00 \\
\hline & 25.00 & 20.00 & 10.00 \\
\hline & 5.84 & 95.00 & 10.00 \\
\hline & 96.52 & 95.00 & 10.00 \\
\hline$c$ & 36.52 & 35.00 & 40.00 \\
\hline \multirow[t]{6}{*}{$c$} & 95.52 & 95.60 & 80.00 \\
\hline & 312.42 & 35.56 & 10.00 \\
\hline & $144.7 \mathrm{~B}$ & -10.00 & 1.0 .00 \\
\hline & 100.00 & 50.00 & 0.15 \\
\hline & 200.00 & 50.00 & 0.15 \\
\hline & 300.00 & 50.00 & 0.15 \\
\hline $\begin{array}{l}\text { prdnap } \\
\text { tot.nut }\end{array}$ & $j \quad-300$ & 13 & \\
\hline print & $12 \mathrm{k}$ & & \\
\hline ctme & 360 & & \\
\hline
\end{tabular}

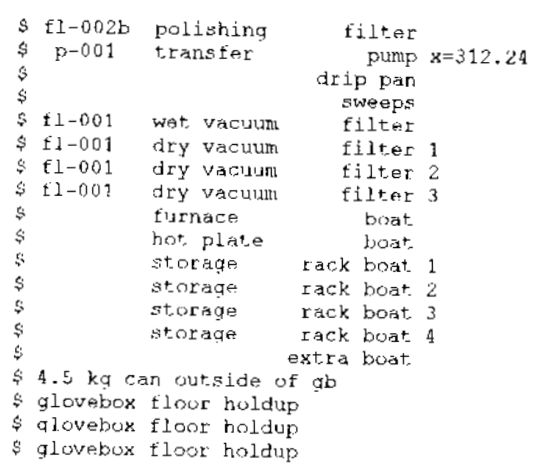

Cas: ccB1

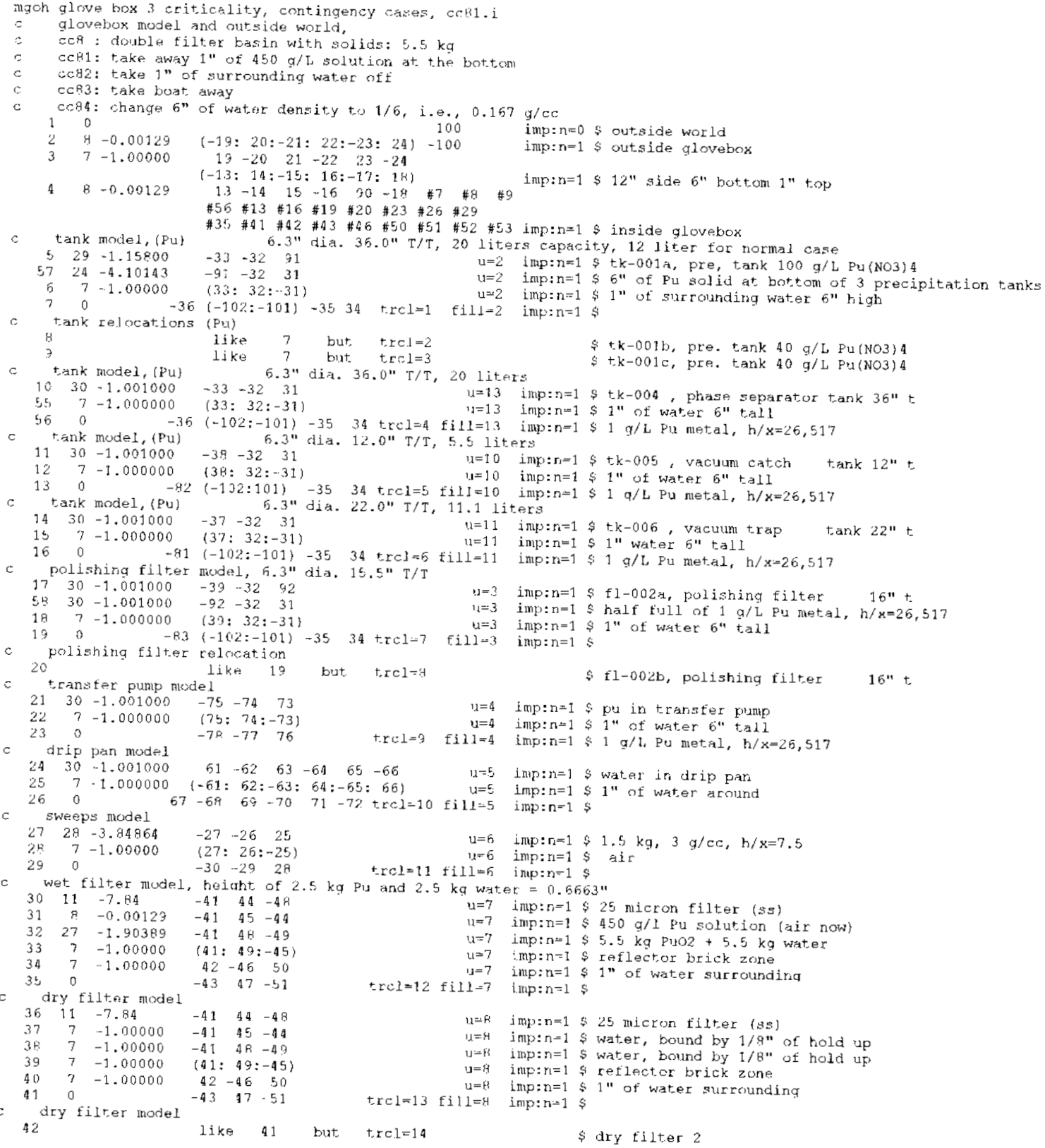


HNF-6537 REV. 0

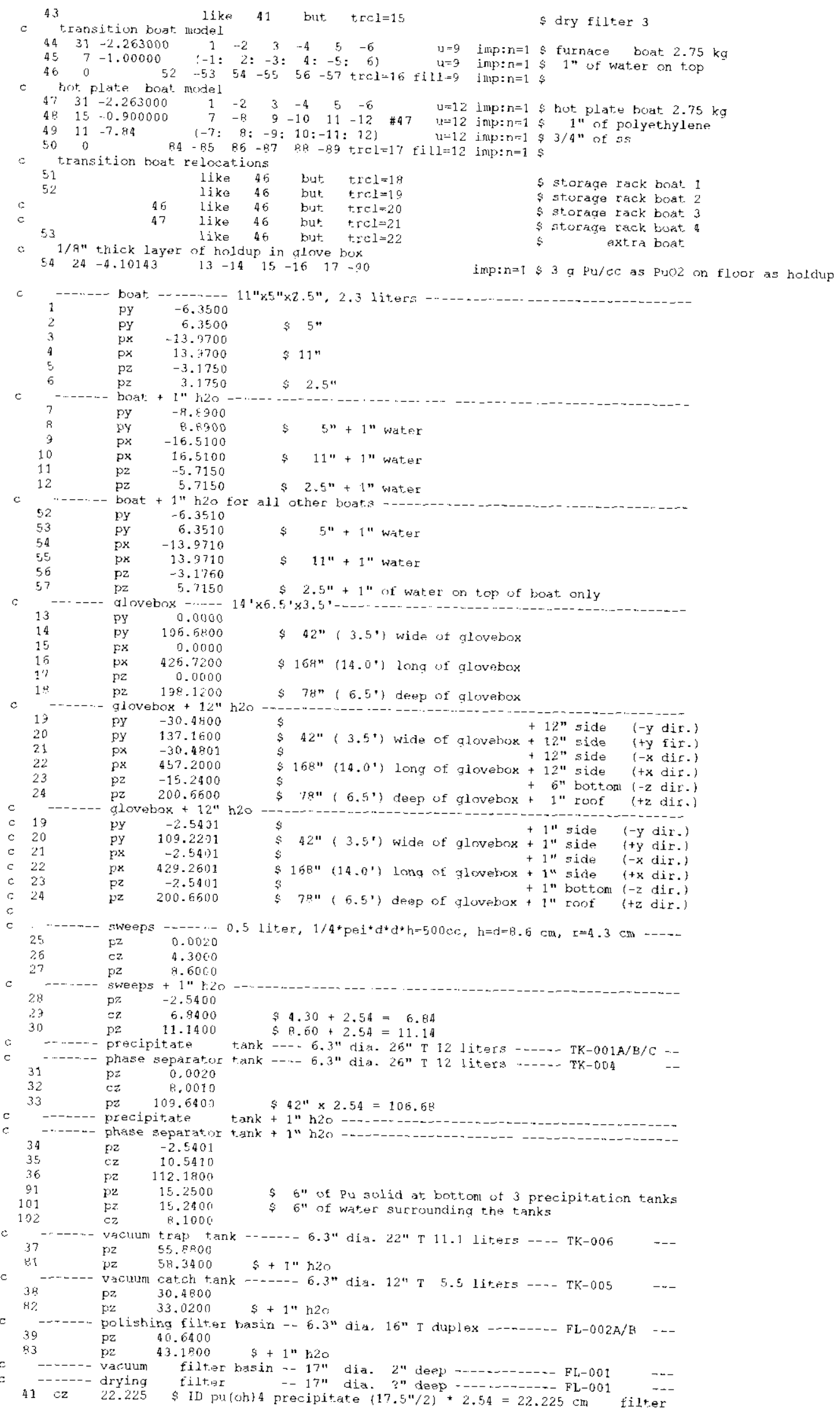




\section{HNF-6537 REV. 0}

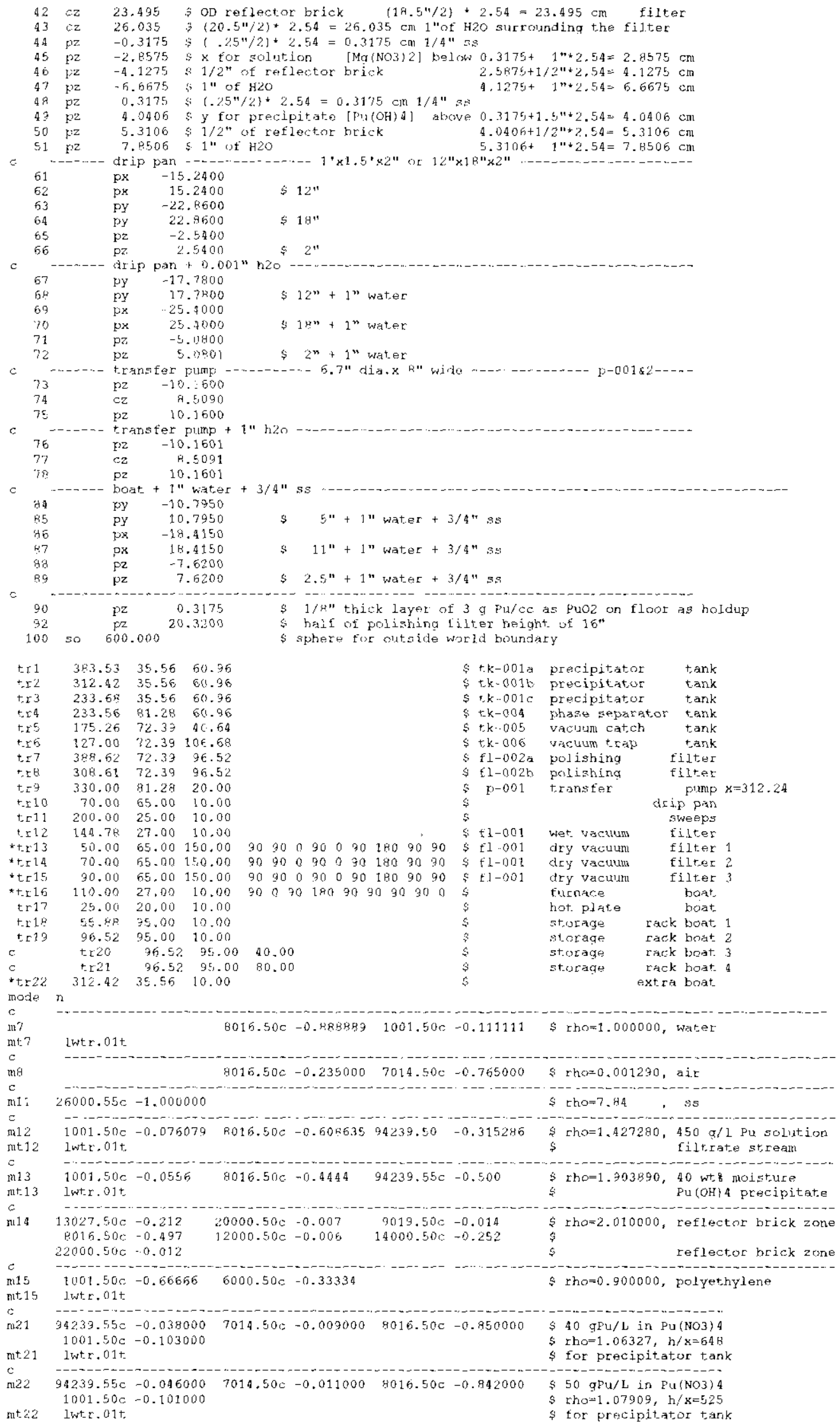




\section{HNF-6537 REV. 0}

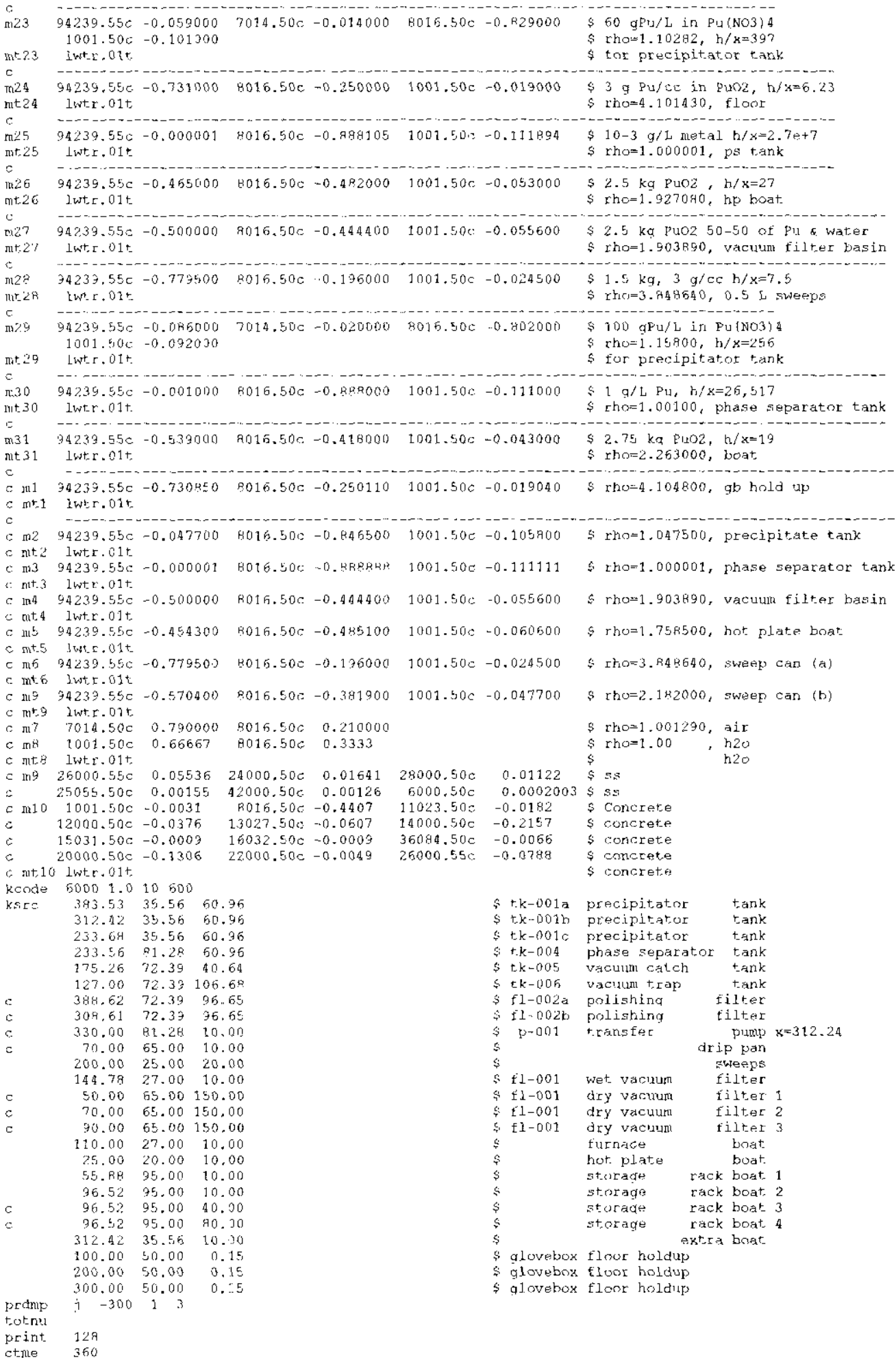

Gase ccs

mgoh glove box 3 criticality, contingency cases, ccs.i - glovebox model and outside world.

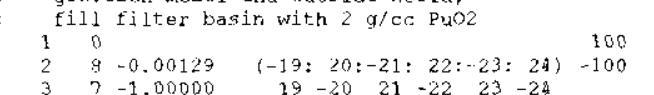




\section{HNF-6537 REV. 0}

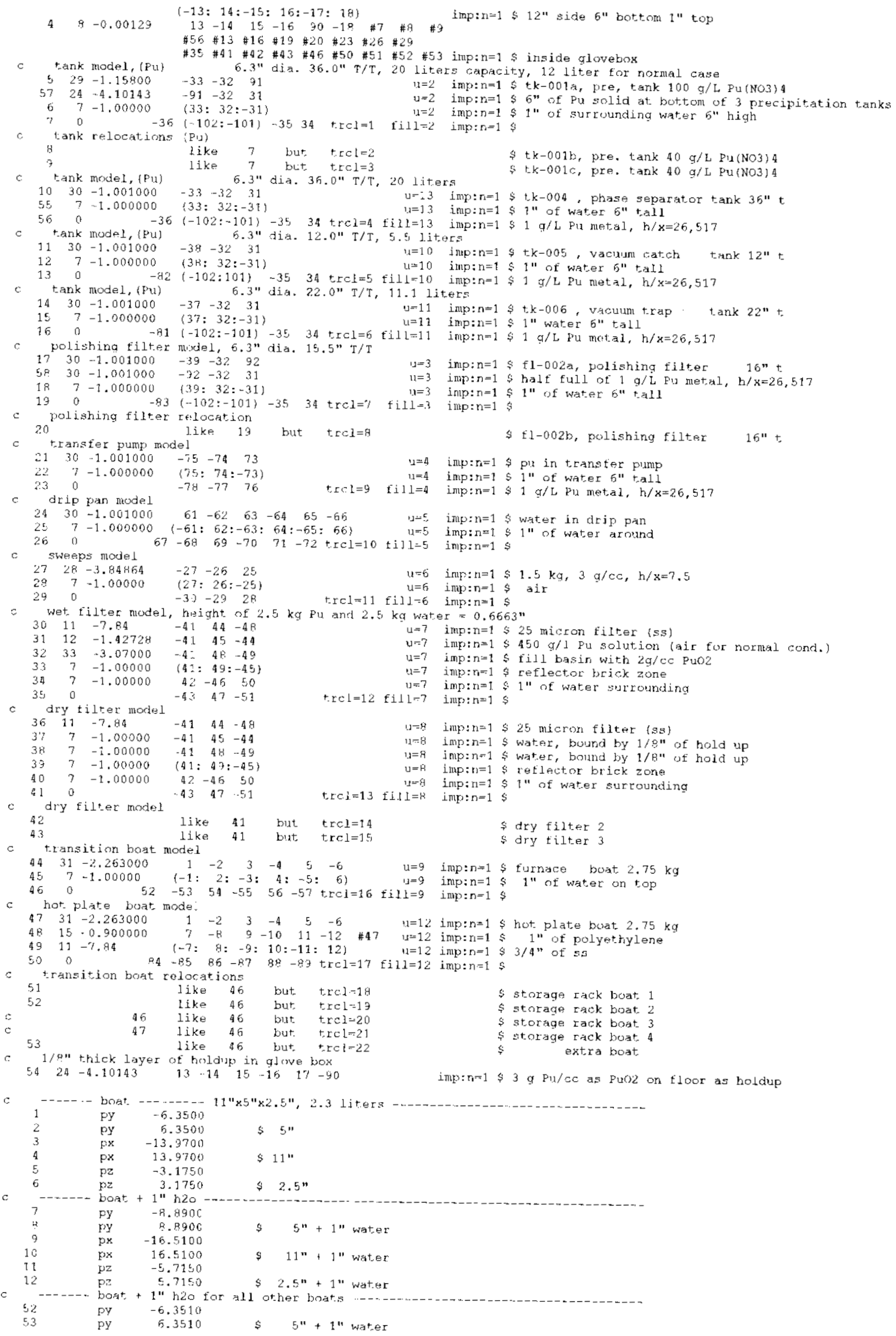


HNF-6537 REV. 0

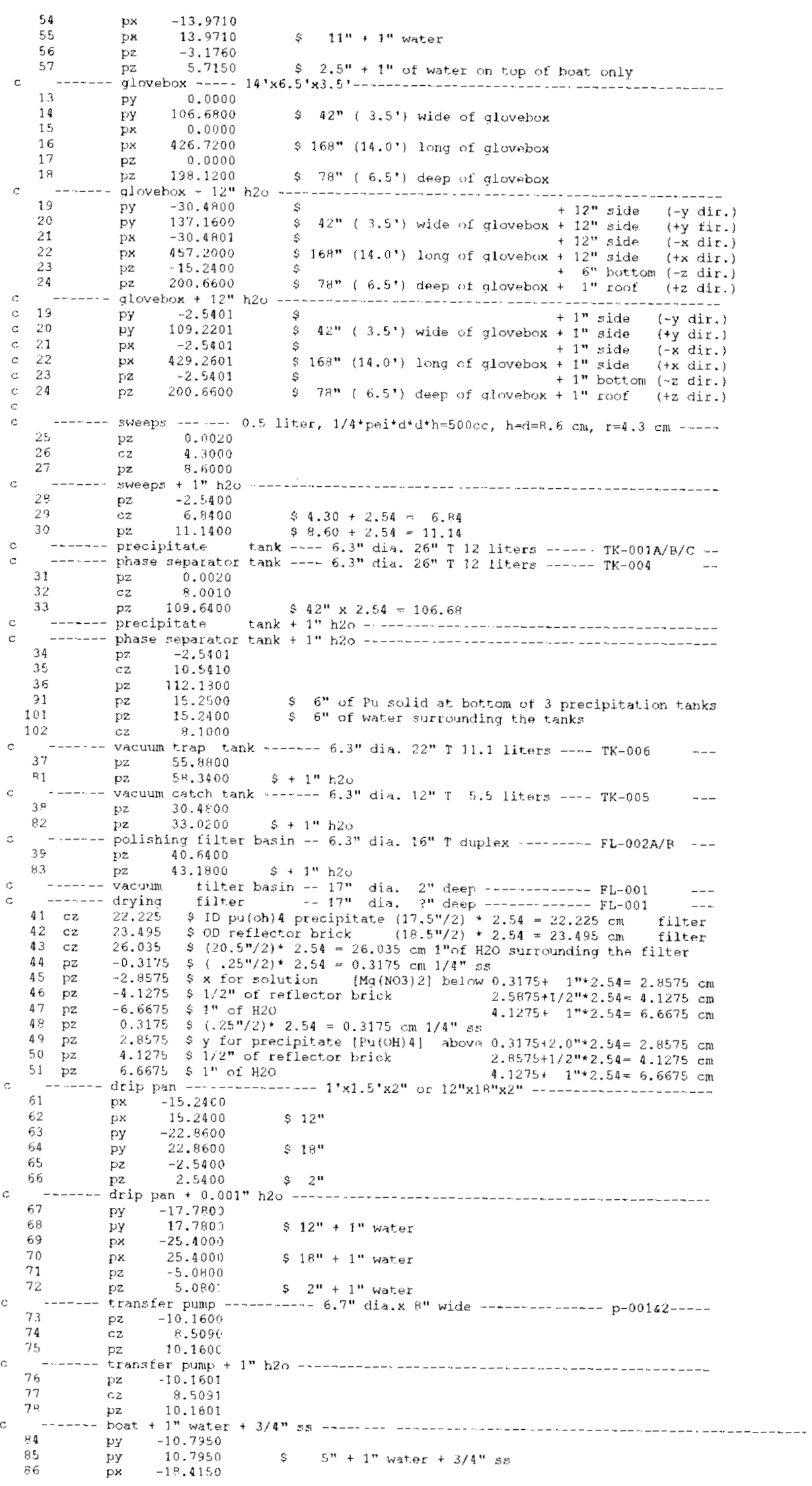




\section{HNF-6537 REV. 0}

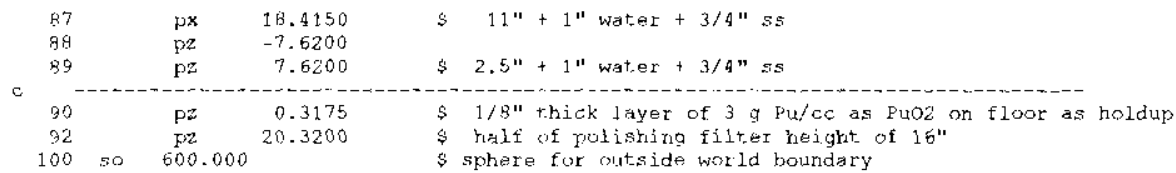

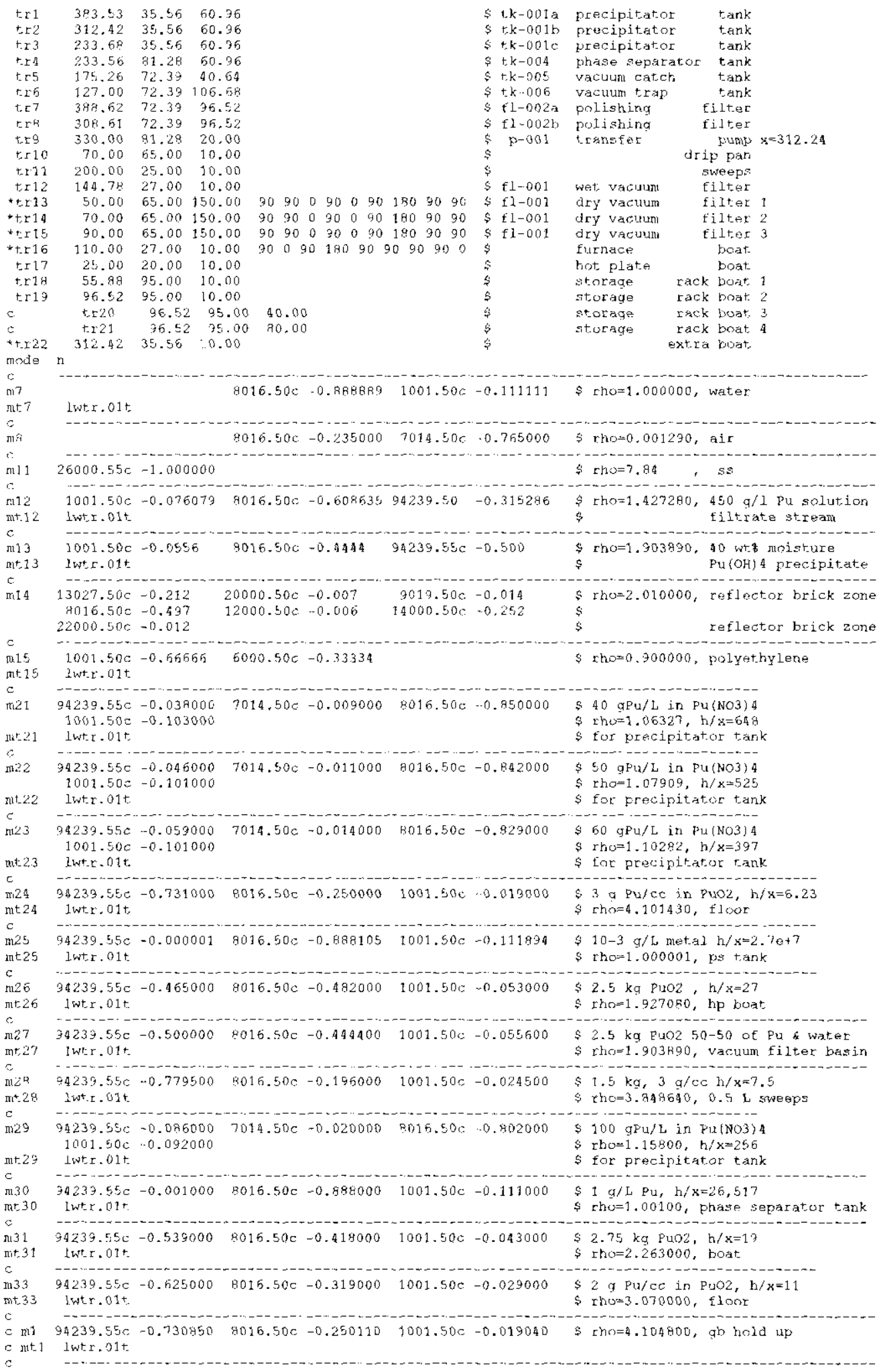


HNE-6537 REV. 0

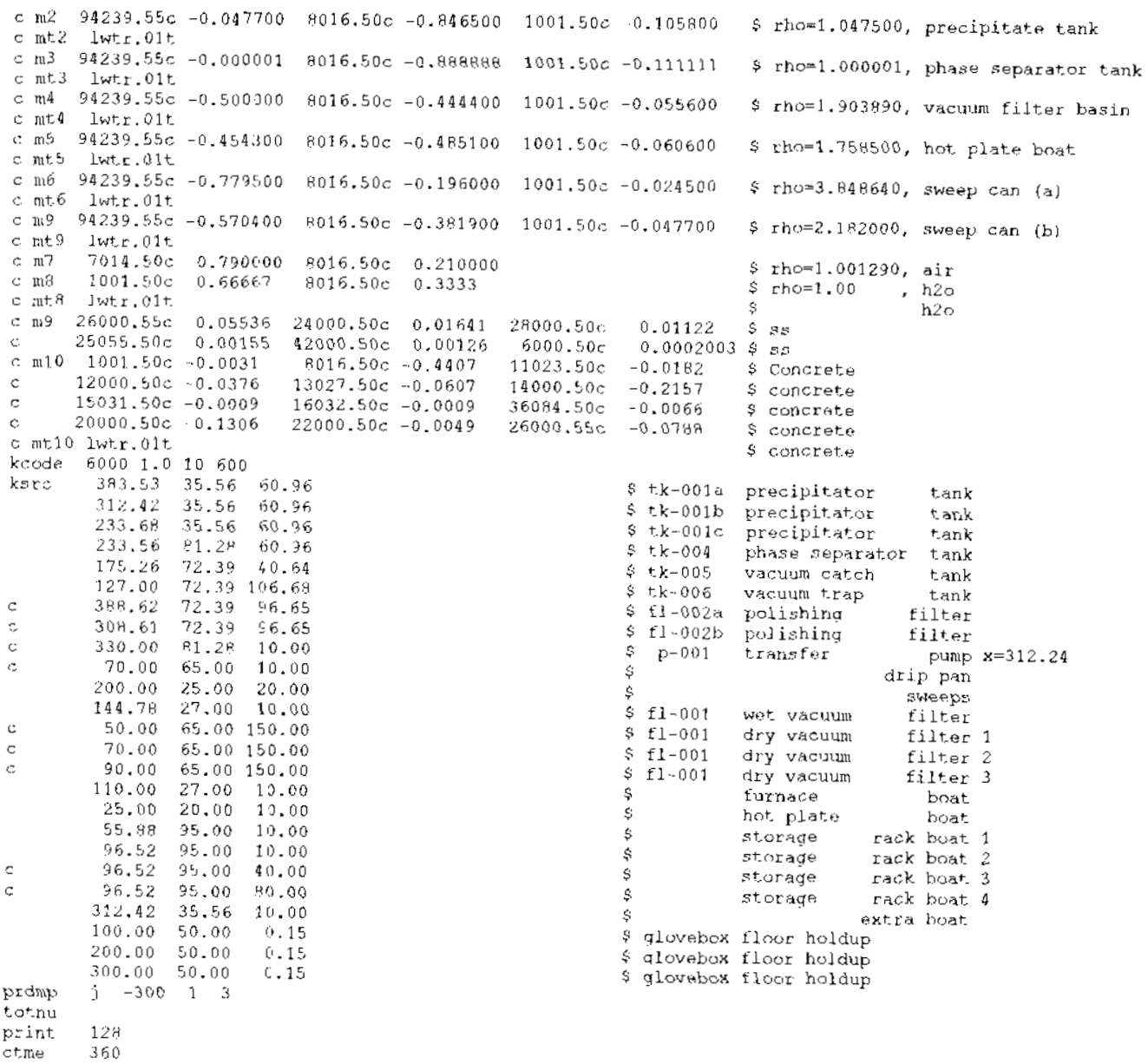

Calse cwac 7.i

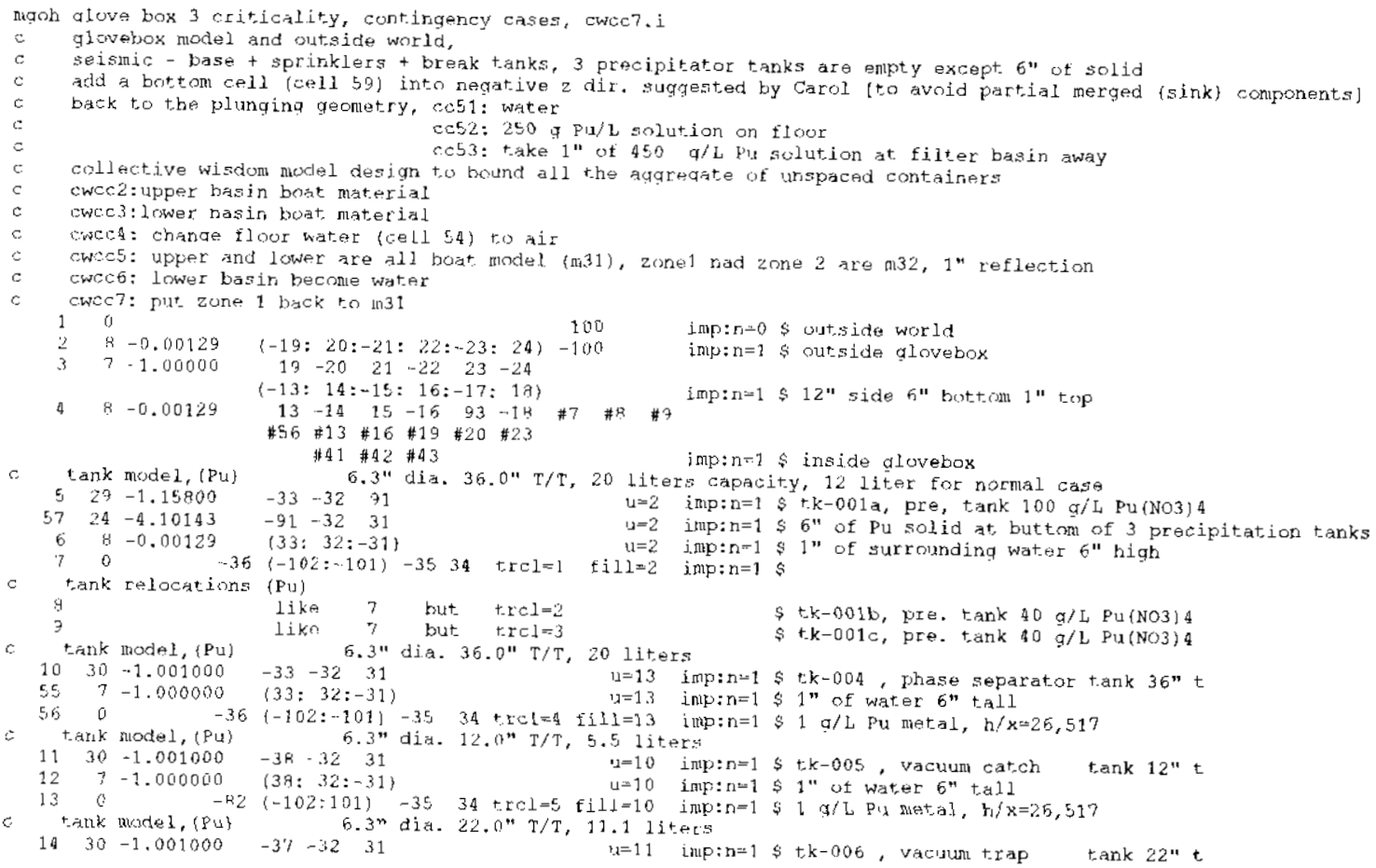




\section{HNF-6537 REV. 0}
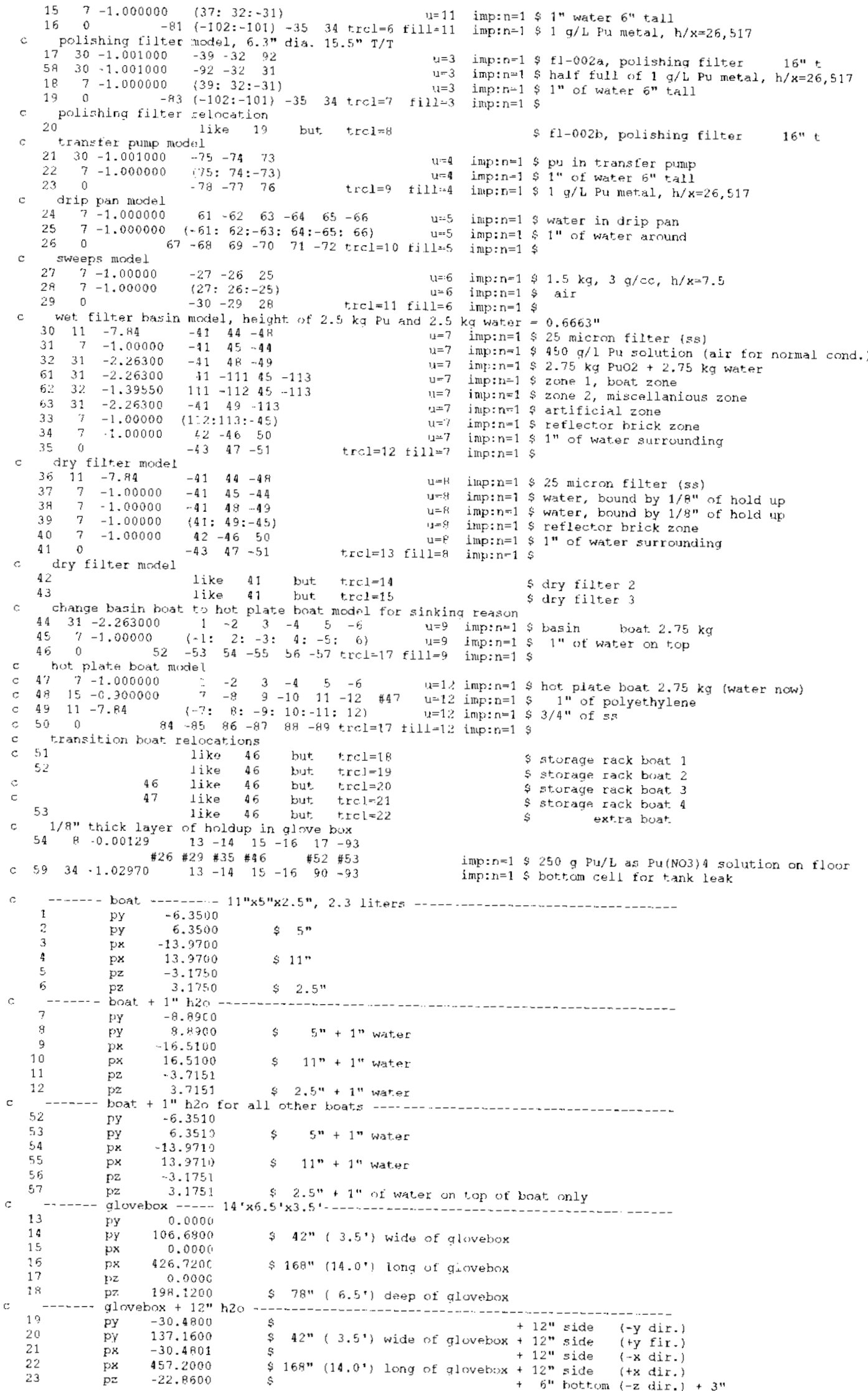


\section{HNF-6537 REV . 0}

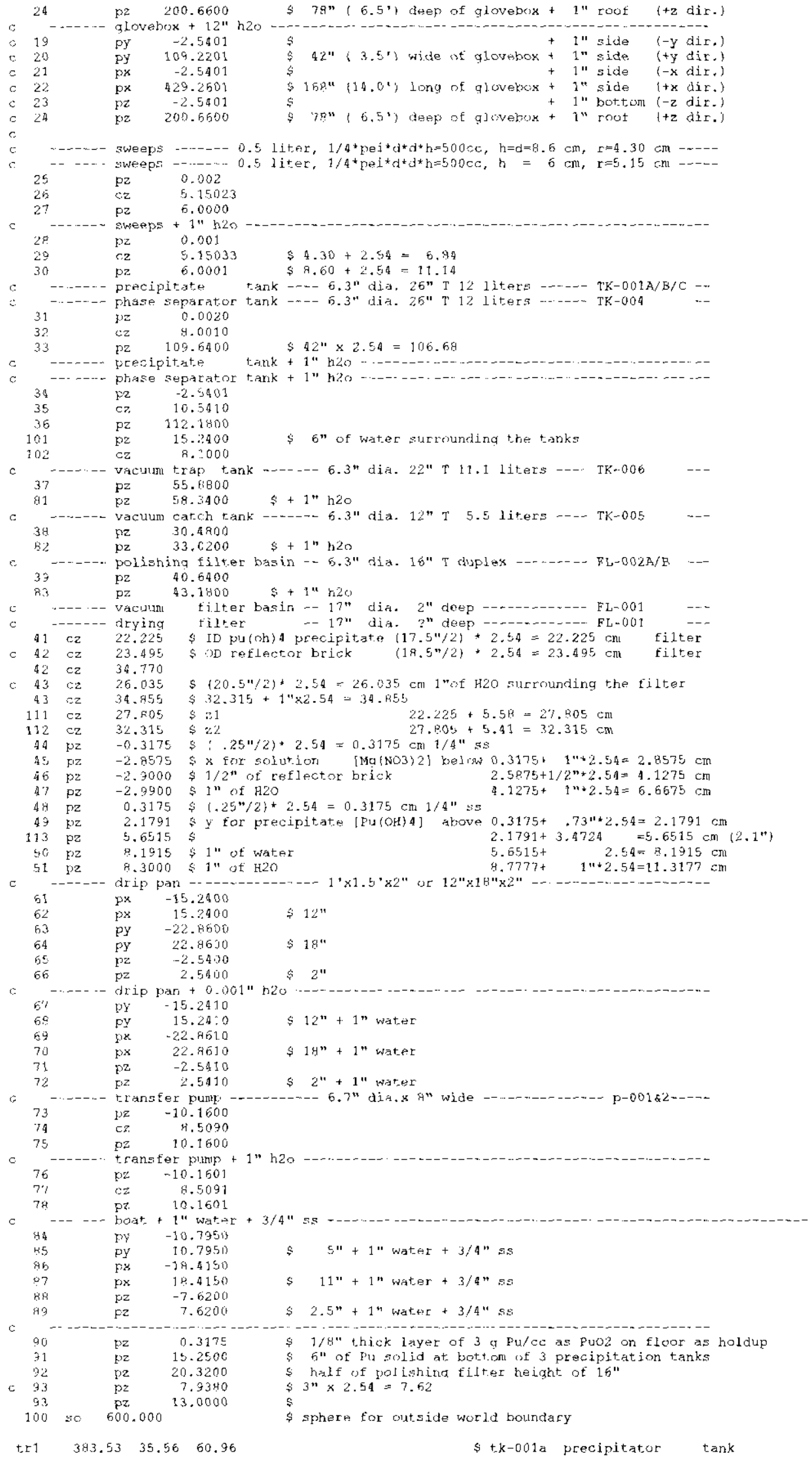




\section{HNF-6537 REV. 0}

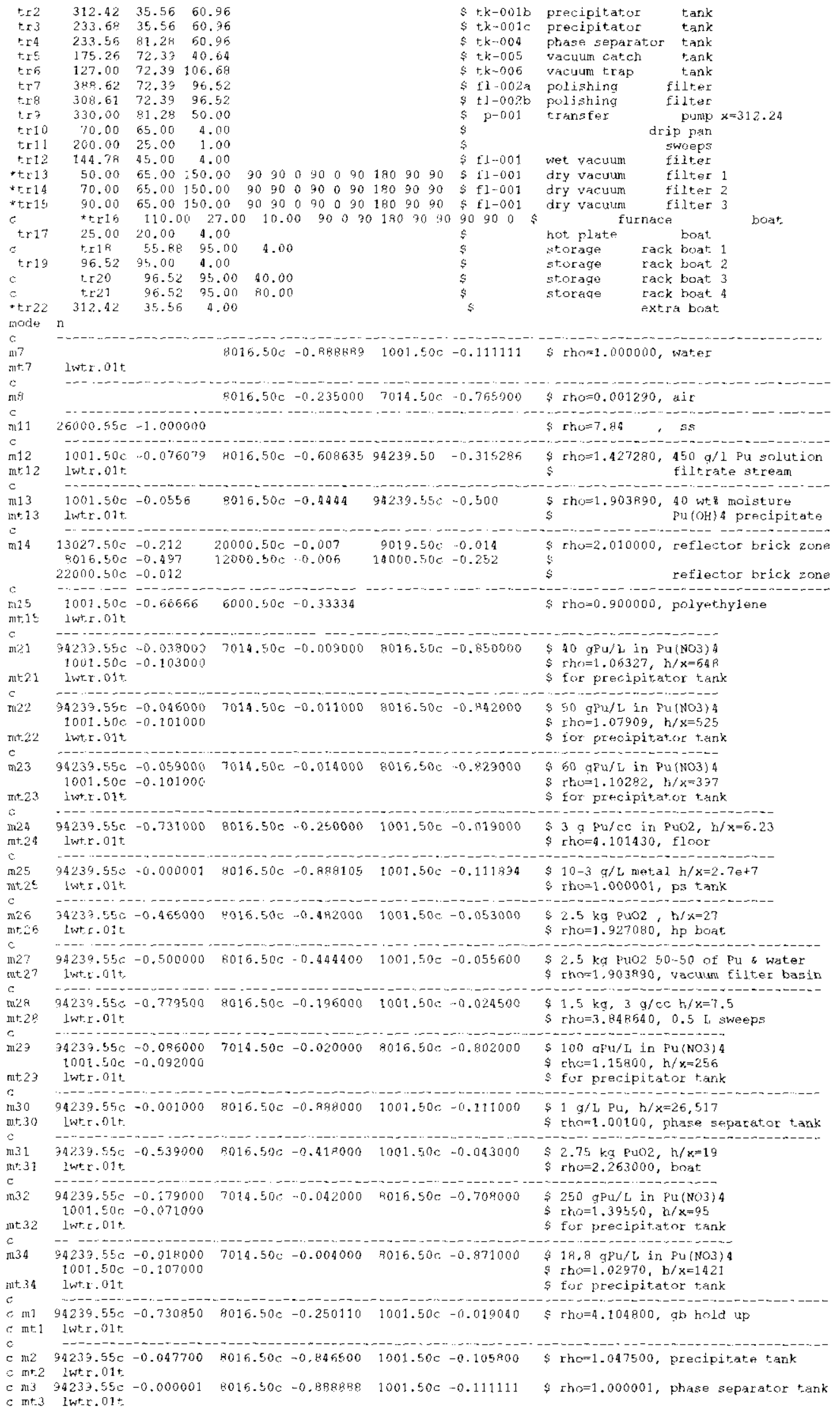




\section{HNF-6537 REV. 0}

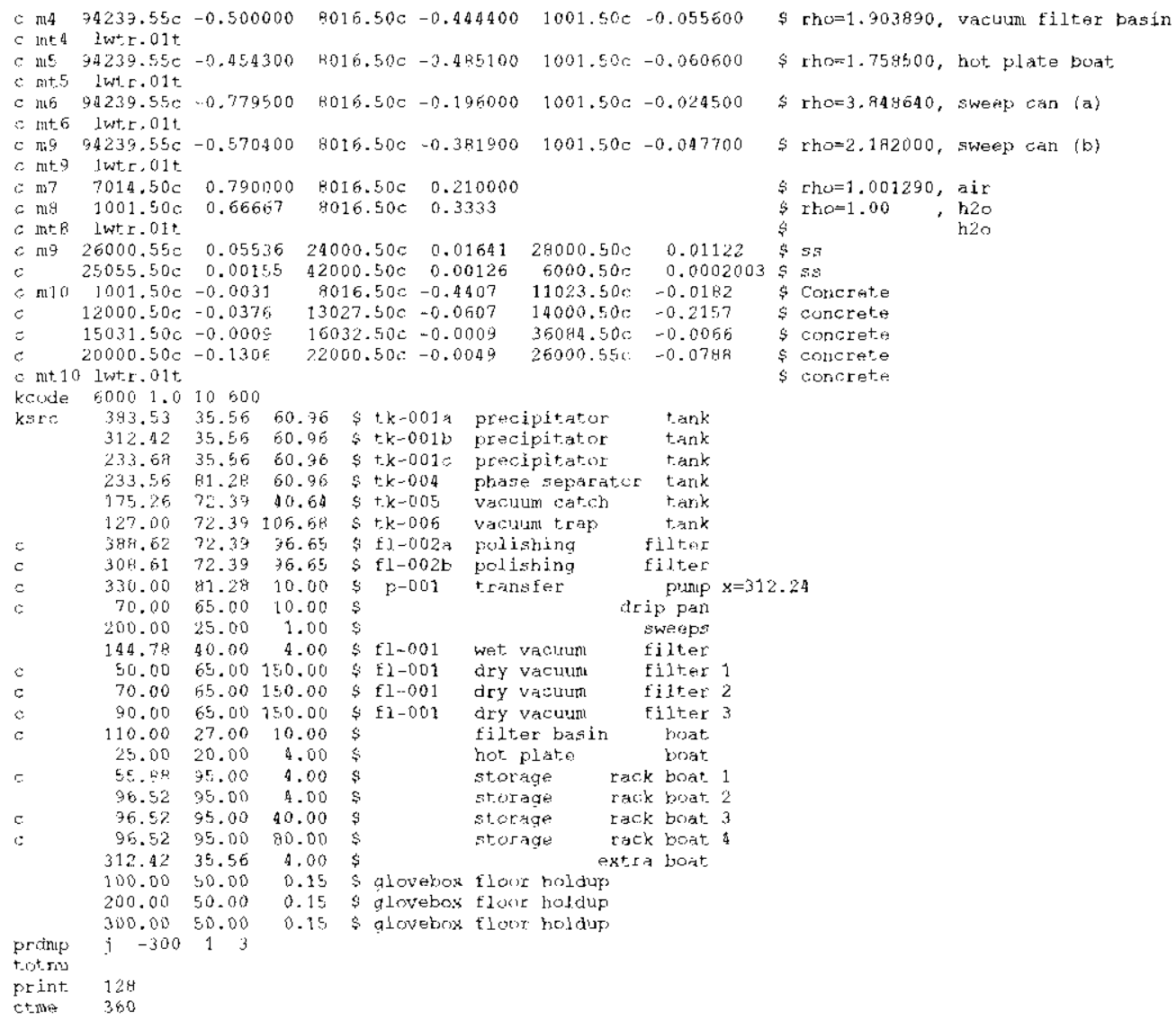


HNF-6537 REV. 0

This page intentionally left blank.

C-44 
HNF-6537 REV. 0

APPENDIX D - HAZARD ANALYSIS

D-1 
HNF-6537 REV. 0

This page intentionally left blank.

D-2 


\begin{tabular}{|c|c|c|c|c|}
\hline \multicolumn{5}{|c|}{$\begin{array}{l}\text { Hazard Assessment of "Magnesium Hydroxide Precipitation Process" } \\
\text { Activity Assessment Team: D. M. Carson, H. L. Chang, D. Clapp, J. S. Lan, E. M. Miller, } \\
\text { A. L. Ramble, L. J. Rosane, H. Toffer }\end{array}$} \\
\hline $\begin{array}{c}\text { Item } \\
\#\end{array}$ & Condition & Hazard/Consequence & Safeguard & Resolution \\
\hline 1 & $\begin{array}{l}\text { Transfer of Pu solution to } \\
\text { blend tanks - No Pu in } \\
\text { solution reaching blend tanks } \\
\text { when expected (Mass - NO) } \\
\text { due to misrouting between } \\
\text { Pu solution container and } \\
\text { blend tanks }\end{array}$ & $\begin{array}{l}\text { Solution leak onto } \\
\text { floor of prep glovebox } \\
\text { room. }\end{array}$ & $\begin{array}{l}\text { Leak onto floor is } \\
\text { critically safe. } \\
\text { Procedures/manua } \\
1 \text { operation with } \\
\text { visual monitoring. }\end{array}$ & $\begin{array}{l}\text { N/A for } \\
\text { Glovebox } 3\end{array}$ \\
\hline 2 & $\begin{array}{l}\text { Transfer of Pu solution to } \\
\text { blend tanks - No Pu in } \\
\text { solution reaching blend tanks } \\
\text { when expected (Mass - NO) } \\
\text { due to misrouting between } \\
\text { Pu solution container and } \\
\text { blend tanks }\end{array}$ & $\begin{array}{l}\text { Solution into some } \\
\text { other tank in prep } \\
\text { glovebox. }\end{array}$ & $\begin{array}{l}\text { All tanks in prep } \\
\text { glovebox are } \\
\text { critically safe } \\
\text { (6" dia.). } \\
\text { Procedures/manua } \\
\text { l operation with } \\
\text { visual monitoring. }\end{array}$ & $\begin{array}{l}\text { N/A for } \\
\text { Glovebox } 3\end{array}$ \\
\hline 3 & $\begin{array}{l}\text { Transfer of Pu solution to } \\
\text { blend tanks - No Pu in } \\
\text { solution reaching blend tanks } \\
\text { when expected (Mass - NO) } \\
\text { due to misrouting between } \\
\text { Pu solution container and } \\
\text { blend tanks }\end{array}$ & $\begin{array}{l}\text { Solution flows into } \\
\text { plant vacuum system. }\end{array}$ & $\begin{array}{l}\text { Vacuum system } \\
\text { has leak detection } \\
\text { leading to } \\
\text { shutdown. } \\
\text { Vacuum system is } \\
\text { critically safe and } \\
\text { has criticality } \\
\text { controls in place. } \\
\text { Procedures/manua } \\
1 \text { operation with } \\
\text { visual monitoring. }\end{array}$ & $\begin{array}{l}\text { N/A for } \\
\text { Glovebox } 3\end{array}$ \\
\hline 4 & $\begin{array}{l}\text { Transfer of Pu solution to } \\
\text { blend tanks - No Pu in } \\
\text { solution reaching blend tanks } \\
\text { when expected (Mass - NO) } \\
\text { due to no Pu in transferred } \\
\text { solution }\end{array}$ & None. & $\mathrm{N} / \mathrm{A}$ & $\begin{array}{l}\text { N/A for } \\
\text { Glovebox } 3\end{array}$ \\
\hline
\end{tabular}




\begin{tabular}{|c|c|c|c|c|}
\hline \multicolumn{5}{|c|}{$\begin{array}{l}\text { Hazard Assessment of "Magnesium Hydroxide Precipitation Process" } \\
\text { Activity Assessment Team: D. M. Carson, H. L. Chang, D. Clapp, J. S. Lan, E. M. Miller, } \\
\text { A. L. Ramble, L. J. Rosane, H. Toffer }\end{array}$} \\
\hline $\begin{array}{c}\text { Item } \\
\#\end{array}$ & Condition & Hazard/Consequence & Safeguard & Resolution \\
\hline 5 & $\begin{array}{l}\text { Transfer of Pu solution to } \\
\text { blend tanks - No Pu in } \\
\text { solution reaching blend tanks } \\
\text { when expected (Mass - NO) } \\
\text { due to liquid evaporating } \\
\text { from solution in Pu solution } \\
\text { container leaving solution } \\
\text { too thick to transfer }\end{array}$ & $\begin{array}{l}\text { Increased } \\
\text { concentration in } \\
\text { solution container. }\end{array}$ & & $\begin{array}{l}\text { N/A for } \\
\text { Glovebox } 3\end{array}$ \\
\hline 6 & $\begin{array}{l}\text { Transfer of Pu solution to } \\
\text { blend tanks - More Pu } \\
\text { reaching blend tanks than } \\
\text { expected due to human error } \\
\text { (Mass - MORE) }\end{array}$ & $\begin{array}{l}\text { None. Tanks in the } \\
\text { prep glovebox have } \\
\text { been analyzed for } 20 \\
\mathrm{~kg} \text { of } \mathrm{Pu} \text {, and } 2 \mathrm{Pu} \\
\text { solution containers } \\
\text { will not hold that } \\
\text { amount. }\end{array}$ & $\begin{array}{l}\text { Procedural limit of } \\
\text { handling only one } \\
\text { Pu solution } \\
\text { container at a } \\
\text { time. }\end{array}$ & $\begin{array}{l}\text { N/A for } \\
\text { Glovebox } 3\end{array}$ \\
\hline 7 & $\begin{array}{l}\text { Transfer of Pu solution to } \\
\text { blend tanks - Other } \\
\text { chemicals (e.g., organics) } \\
\text { entering blend tanks due to a } \\
\text { human error (Mass - AS } \\
\text { WELL AS) }\end{array}$ & $\begin{array}{l}\text { None related to } \\
\text { criticality. }\end{array}$ & $\begin{array}{l}\text { Pu solution } \\
\text { container handling } \\
\text { controls. }\end{array}$ & $\begin{array}{l}\text { N/A for } \\
\text { Glovebox } 3\end{array}$ \\
\hline 8 & $\begin{array}{l}\text { Transfer from blend tanks to } \\
\text { precipitators - No solution } \\
\text { reaching precipitators when } \\
\text { expected due to a piping leak } \\
\text { while line containment drain } \\
\text { pathway to gloveboxes is } \\
\text { blocked (Mass - NO) }\end{array}$ & $\begin{array}{l}\text { Leak into plugged } \\
\text { containment line. }\end{array}$ & $\begin{array}{l}\text { Piping and piping } \\
\text { containment are } \\
\text { geometrically } \\
\text { favorable. }\end{array}$ & Not credible. \\
\hline 9 & $\begin{array}{l}\text { Transfer from blend tanks to } \\
\text { precipitators - No solution } \\
\text { reaching precipitators when } \\
\text { expected due to a piping leak } \\
\text { while line containment drain } \\
\text { pathway into glovebox } 3 \text { is } \\
\text { open (Mass - NO) }\end{array}$ & $\begin{array}{l}\text { Solution leak onto } \\
\text { floor of prep glovebox } \\
\text { room. }\end{array}$ & $\begin{array}{l}\text { Leak onto floor is } \\
\text { critically safe. } \\
\text { Procedures/manua } \\
1 \text { operation with } \\
\text { visual monitoring. }\end{array}$ & $\begin{array}{l}\text { N/A for } \\
\text { Glovebox } 3\end{array}$ \\
\hline
\end{tabular}




\begin{tabular}{|c|c|c|c|c|}
\hline \multicolumn{5}{|c|}{$\begin{array}{l}\text { Hazard Assessment of "Magnesium Hydroxide Precipitation Process" } \\
\text { Activity Assessment Team: D. M. Carson, H. L. Chang, D. Clapp, J. S. Lan, E. M. Miller, } \\
\text { A. L. Ramble, L. J. Rosane, H. Toffer }\end{array}$} \\
\hline $\begin{array}{c}\text { Item } \\
\#\end{array}$ & Condition & Hazard/Consequence & Safeguard & Resolution \\
\hline 10 & $\begin{array}{l}\text { Transfer from blend tanks to } \\
\text { precipitators - No solution } \\
\text { reaching precipitators when } \\
\text { expected due to a flow } \\
\text { reversal through Pump B } \\
\text { (Mass - NO) }\end{array}$ & None. & $\begin{array}{l}\text { Design of pump } \\
\text { precludes } \\
\text { possibility of } \\
\text { reverse flow. }\end{array}$ & Not credible. \\
\hline 11 & $\begin{array}{l}\text { Transfer from blend tanks to } \\
\text { precipitators - No solution } \\
\text { reaching precipitators when } \\
\text { expected due to a fractured } \\
\text { transfer pipe and } \\
\text { containment during a seismic } \\
\text { event (Mass - NO) }\end{array}$ & $\begin{array}{l}\text { Spray leak of solution } \\
\text { from fractured transfer } \\
\text { pipe and containment. }\end{array}$ & $\begin{array}{l}\text { Pipe may be } \\
\text { seismically } \\
\text { qualified. } \\
\text { Housekeeping } \\
\text { procedures and } \\
\text { training - no open } \\
\text { containers are } \\
\text { normally allowed } \\
\text { on the floor. }\end{array}$ & $\begin{array}{l}\text { Not credible } \\
\text { per discussion } \\
\text { in Section } 3.4\end{array}$ \\
\hline 12 & $\begin{array}{l}\text { Transfer from blend tanks to } \\
\text { precipitators - No solution } \\
\text { reaching precipitators when } \\
\text { expected due to a fractured } \\
\text { transfer pipe and } \\
\text { containment during a seismic } \\
\text { event (Mass - NO) }\end{array}$ & $\begin{array}{l}\text { Spray leak of solution } \\
\text { from fractured transfer } \\
\text { pipe and containment } \\
\text { into uncontrolled, } \\
\text { non-critically-safe, } \\
\text { open container on } \\
\text { floor beneath pipe. }\end{array}$ & $\begin{array}{l}\text { Pipe may be } \\
\text { seismically } \\
\text { qualified. } \\
\text { Housekeeping } \\
\text { procedures and } \\
\text { training - no open } \\
\text { containers are } \\
\text { normally allowed } \\
\text { on the floor. }\end{array}$ & $\begin{array}{l}\text { Not credible } \\
\text { per discussion } \\
\text { in Section } 3.4\end{array}$ \\
\hline 13 & $\begin{array}{l}\text { Transfer from blend tanks to } \\
\text { precipitators - Interaction } \\
\text { between tank and glovebox } \\
\text { contents (Interaction) }\end{array}$ & $\begin{array}{l}\text { Interaction between } \\
\text { tank(s) and glovebox } \\
\text { contents. }\end{array}$ & None. & $\begin{array}{l}\text { Base case in } \\
\text { Section } 5.2 \\
\text { (bc) }\end{array}$ \\
\hline 14 & $\begin{array}{l}\text { Transfer from blend tanks to } \\
\text { precipitators - Increased - } \\
\text { reflected tanks (Reflection - } \\
\text { FULL) }\end{array}$ & $\begin{array}{l}\text { Increased reflection of } \\
\text { tanks. }\end{array}$ & Criticality drain. & $\begin{array}{l}\text { Fire and } \\
\text { Seismic } \\
\text { scenarios in } \\
\text { Section } 5.3 \\
\text { (cc5 and cc6) }\end{array}$ \\
\hline
\end{tabular}




\begin{tabular}{|c|c|c|c|c|}
\hline \multicolumn{5}{|c|}{$\begin{array}{l}\text { Hazard Assessment of "Magnesium Hydroxide Precipitation Process" } \\
\text { Activity Assessment Team: D. M. Carson, H. L. Chang, D. Clapp, J. S. Lan, E. M. Miller, } \\
\text { A. L. Ramble, L. J. Rosane, H. Toffer }\end{array}$} \\
\hline $\begin{array}{c}\text { Item } \\
\#\end{array}$ & Condition & Hazard/Consequence & Safeguard & Resolution \\
\hline 15 & $\begin{array}{l}\text { Transfer from blend tanks to } \\
\text { precipitators - Optimally- } \\
\text { moderated tanks } \\
\text { (Moderation - FULL) }\end{array}$ & $\begin{array}{l}\text { Optimally-moderated } \\
\text { tanks. }\end{array}$ & Normal operation. & $\begin{array}{l}\text { Optimally } \\
\text { moderated } \\
\text { solution } \\
\text { scenario in } \\
\text { Section } 5.3 \\
\text { (cc1) }\end{array}$ \\
\hline 16 & $\begin{array}{l}\text { Transfer from blend tanks to } \\
\text { precipitators with an } \\
\text { excessive solution } \\
\text { concentration (Mass - } \\
\text { HIGH) }\end{array}$ & $\begin{array}{l}\text { Excess Pu mass in } \\
\text { solution. }\end{array}$ & $\begin{array}{l}\text { Maximum } \mathrm{Pu} \\
\text { concentration that } \\
\text { remains pumpable } \\
\text { is } 450 \mathrm{~g} / \mathrm{L} \text {. }\end{array}$ & $\begin{array}{l}\text { Bound by } \\
\text { optimally } \\
\text { moderated } \\
\text { solution } \\
\text { scenario in } \\
\text { Section } 5.3 \\
\text { (cc1) }\end{array}$ \\
\hline 17 & $\begin{array}{l}\text { Transfer from blend tanks to } \\
\text { precipitators with a high } \\
\text { solution temperature } \\
\text { (Temperature - HIGH) }\end{array}$ & $\begin{array}{l}\text { Reactivity increase by } \\
\text { positive temperature } \\
\text { coefficient during } \\
\text { neutralization of acid. }\end{array}$ & $\begin{array}{l}\text { Procedures, blend } \\
\text { plan. }\end{array}$ & $\begin{array}{l}\text { Too small } \\
\text { temperature } \\
\text { change to affect } \\
\text { reactivity }\end{array}$ \\
\hline 18 & $\begin{array}{l}\text { Transfer from blend tanks to } \\
\text { precipitators - High volume } \\
\text { (Volume - HIGH) }\end{array}$ & $\begin{array}{l}\text { Excess } \mathrm{Pu} \text { in } \\
\text { precipitator. }\end{array}$ & $\begin{array}{l}20 \mathrm{~L} \text { capacity of } \\
\text { tanks. }\end{array}$ & $\begin{array}{l}\text { Base case in } \\
\text { Section } 5.2 \\
\text { (bc) }\end{array}$ \\
\hline 19 & $\begin{array}{l}\text { Filtering feed solution when } \\
\text { no precipitation has occurred } \\
\text { (Mass - NO) }\end{array}$ & $\begin{array}{l}\text { High } \mathrm{Pu} \\
\text { concentrations } \\
\text { downstream of filter } \\
\text { (TK-004, filtrate } \\
\text { tanks) }\end{array}$ & $\begin{array}{l}\text { Procedures, blend } \\
\text { plan, analysis of } \\
\text { feed. }\end{array}$ & $\begin{array}{l}\text { N/A for filtrate } \\
\text { tanks for } \\
\text { Glovebox } 3 \\
\text { Increased } \\
\text { concentration in } \\
\text { vacuum tanks } \\
\text { and phase } \\
\text { separator ( } 40 \\
\text { and } 65 \mathrm{~g} / \mathrm{L} \text { ) } \\
\text { (cc2a and } \mathrm{cc} 2 \mathrm{~b} \text { ) }\end{array}$ \\
\hline 20 & $\begin{array}{l}\text { Filtering feed solution with } \\
\text { no Pu in it (Mass - NO) }\end{array}$ & No criticality concern. & N/A & N/A \\
\hline
\end{tabular}




\begin{tabular}{|c|c|c|c|c|}
\hline \multicolumn{5}{|c|}{$\begin{array}{l}\text { Hazard Assessment of "Magnesium Hydroxide Precipitation Process" } \\
\text { Activity Assessment Team: D. M. Carson, H. L. Chang, D. Clapp, J. S. Lan, E. M. Miller, } \\
\text { A. L. Ramble, L. J. Rosane, H. Toffer }\end{array}$} \\
\hline $\begin{array}{c}\text { Item } \\
\#\end{array}$ & Condition & Hazard/Consequence & Safeguard & Resolution \\
\hline 21 & $\begin{array}{l}\text { Filtering precipitate with a } \\
\text { low amount of Pu in it after } \\
\text { lower than anticipated } \\
\text { precipitation due to } \\
\text { insufficient } \mathrm{Mg}(\mathrm{OH})_{2} \\
\text { addition or a bad analysis } \\
\text { (Mass - LOW) }\end{array}$ & $\begin{array}{l}\text { High } \mathrm{Pu} \\
\text { concentrations } \\
\text { downstream of filter } \\
\text { (TK-004, filtrate } \\
\text { tanks) }\end{array}$ & $\begin{array}{l}\text { Procedures, blend } \\
\text { plan, analysis of } \\
\text { feed. }\end{array}$ & See Item $\# 19$ \\
\hline 22 & $\begin{array}{l}\text { Filtering precipitate with a } \\
\text { higher than normal amount } \\
\text { of Pu from a higher than } \\
\text { expected Pu in the feed due } \\
\text { to a bad analysis (Mass - } \\
\text { HIGH) }\end{array}$ & $\begin{array}{l}\text { Excess Pu mass in } \\
\text { filter. }\end{array}$ & $\begin{array}{l}\text { Procedures, blend } \\
\text { plan, analysis of } \\
\text { feed. }\end{array}$ & $\begin{array}{l}\text { Filter basin } \\
\text { with } 5.5 \mathrm{~kg} \\
\text { solids scenario } \\
\text { in Section } 5.3 \\
(\mathrm{cc} 8)\end{array}$ \\
\hline 23 & $\begin{array}{l}\text { Filtering precipitate with an } \\
\text { excess of flocculent (Mass - } \\
\text { OTHER THAN) }\end{array}$ & $\begin{array}{l}\text { Increase in } \\
\text { moderation in filter. }\end{array}$ & Procedures. & $\begin{array}{l}\text { Filter modeled } \\
\text { in base case at } \\
\mathrm{H} / \mathrm{X} \text { ratios of } \\
27 \text { and } 57 . \text { This } \\
\text { bounds any } \\
\text { credible } \\
\text { increase in } \\
\text { flocculent }\end{array}$ \\
\hline 24 & $\begin{array}{l}\text { Filtering precipitate with a } \\
\text { full furnace boat next to the } \\
\text { filter (Geometry/Interaction) }\end{array}$ & $\begin{array}{l}\text { Interaction between } \\
\text { Pu-bearing items in } \\
\text { glovebox. }\end{array}$ & Procedures & $\begin{array}{l}\text { Bound by filter } \\
\text { basin with } \\
5.5 \mathrm{~kg} \text { solids } \\
\text { scenario in } \\
\text { Section } 5.3 \\
\text { (cc8) }\end{array}$ \\
\hline 25 & $\begin{array}{l}\text { Filtering precipitate with } \\
\text { Operator's hands near filter } \\
\text { (Reflection) }\end{array}$ & Increased reflection & $\begin{array}{l}\text { Limited number of } \\
\text { gloves available in } \\
\text { filter area limits } \\
\text { the number of } \\
\text { hands that can be } \\
\text { near the filter at } \\
\text { once. }\end{array}$ & $\begin{array}{l}\text { Base and } \\
\text { contingency } \\
\text { cases modeled } \\
1 \text { in. water } \\
\text { reflection } \\
\text { around filter }\end{array}$ \\
\hline
\end{tabular}




\begin{tabular}{|c|c|c|c|c|}
\hline \multicolumn{5}{|c|}{$\begin{array}{l}\text { Hazard Assessment of "Magnesium Hydroxide Precipitation Process" } \\
\text { Activity Assessment Team: D. M. Carson, H. L. Chang, D. Clapp, J. S. Lan, E. M. Miller, } \\
\text { A. L. Ramble, L. J. Rosane, H. Toffer }\end{array}$} \\
\hline $\begin{array}{c}\text { Item } \\
\#\end{array}$ & Condition & Hazard/Consequence & Safeguard & Resolution \\
\hline 26 & $\begin{array}{l}\text { Filtering precipitate with } \\
\text { high- or low-density material } \\
\text { or solutions (Moderation) }\end{array}$ & $\begin{array}{l}\text { Increased range of } \\
\text { moderation }(\mathrm{H} / \mathrm{Pu})\end{array}$ & $\begin{array}{l}\text { Procedures, } \\
\text { control of } \\
\text { chemical addition. }\end{array}$ & $\begin{array}{l}\text { Credible range } \\
\text { of moderation } \\
\text { analyzed for } \\
\text { base case }\end{array}$ \\
\hline 27 & $\begin{array}{l}\text { Filtering precipitate with a } \\
\text { higher than normal amount } \\
\text { of } \mathrm{Pu} \text { from a higher than } \\
\text { expected } \mathrm{Pu} \text { in the feed due } \\
\text { to a high concentration in the } \\
\text { feed (Concentration - HIGH) }\end{array}$ & $\begin{array}{l}\text { Excess Pu mass in } \\
\text { filter. }\end{array}$ & $\begin{array}{l}\text { Procedures, blend } \\
\text { plan, analysis of } \\
\text { feed. }\end{array}$ & $\begin{array}{l}\text { Filter basin } \\
\text { with } 5.5 \mathrm{~kg} \\
\text { solids scenario } \\
\text { in Section } 5.3 \\
(\mathrm{cc} 8)\end{array}$ \\
\hline 28 & $\begin{array}{l}\text { Filtering precipitate with a } \\
\text { higher than normal amount } \\
\text { of Pu from a higher than } \\
\text { expected } \mathrm{Pu} \text { in the feed due } \\
\text { to a higher volume of feed } \\
\text { than expected (Volume - } \\
\text { HIGH) }\end{array}$ & $\begin{array}{l}\text { Excess Pu mass in } \\
\text { filter. }\end{array}$ & $\begin{array}{l}\text { Procedures, blend } \\
\text { plan, analysis of } \\
\text { feed, precipitation } \\
\text { tanks' volume. }\end{array}$ & $\begin{array}{l}\text { Filter basin } \\
\text { with } 5.5 \mathrm{~kg} \\
\text { solids scenario } \\
\text { in Section } 5.3 \\
(\operatorname{cc} 8)\end{array}$ \\
\hline 29 & $\begin{array}{l}\text { Drying precipitate in a } \\
\text { furnace boat on hotplate with } \\
\text { a higher than expected } \\
\text { amount of } \mathrm{Pu} \text { in the boat due } \\
\text { to a higher level of Pu than } \\
\text { expected in the feed due to a } \\
\text { bad analysis (Mass - HIGH) }\end{array}$ & $\begin{array}{l}\text { Increases Pu mass in } \\
\text { boat. }\end{array}$ & $\begin{array}{l}\text { Procedures, blend } \\
\text { plan, analysis of } \\
\text { feed. }\end{array}$ & $\begin{array}{l}\text { Bound by } \\
\text { overloaded boat } \\
\text { in boat rack } \\
(\mathrm{cc} 3)\end{array}$ \\
\hline 30 & $\begin{array}{l}\text { Drying precipitate in a } \\
\text { furnace boat on hotplate with } \\
\text { an increase in moderation as } \\
\text { the water in the precipitate } \\
\text { cake evaporates (Mass - } \\
\text { PART OF, OTHER THAN) }\end{array}$ & $\begin{array}{l}\text { Increases range of } \\
\mathrm{H} / \mathrm{Pu} \text { (moderation) }\end{array}$ & $\begin{array}{l}\text { Small volume of } \\
\text { boat and heat } \\
\text { capacity of heater } \\
\text { compared to } \\
\text { glovebox air } \\
\text { replacement rate. }\end{array}$ & $\begin{array}{l}\text { Base and } \\
\text { contingency } \\
\text { cases modeled } \\
\text { a conservative } \\
\text { range of } \mathrm{H} / \mathrm{X} \\
\text { ratios that } \\
\text { bound any } \\
\text { increase from } \\
\text { evaporation }\end{array}$ \\
\hline
\end{tabular}




\begin{tabular}{|c|c|c|c|c|}
\hline \multicolumn{5}{|c|}{$\begin{array}{l}\text { Hazard Assessment of "Magnesium Hydroxide Precipitation Process" } \\
\text { Activity Assessment Team: D. M. Carson, H. L. Chang, D. Clapp, J. S. Lan, E. M. Miller, } \\
\text { A. L. Ramble, L. J. Rosane, H. Toffer }\end{array}$} \\
\hline $\begin{array}{c}\text { Item } \\
\#\end{array}$ & Condition & Hazard/Consequence & Safeguard & Resolution \\
\hline 31 & $\begin{array}{l}\text { Drying precipitate in a } \\
\text { furnace boat on hotplate with } \\
\text { other materials (e.g., } \\
\mathrm{Mg}(\mathrm{OH})_{2} \text {, silica, etc.) } \\
\text { present in the precipitate } \\
\text { cake (Mass - AS WELL AS) }\end{array}$ & $\begin{array}{l}\text { Decreases concen- } \\
\text { tration of } \mathrm{Pu}(\mathrm{OH})_{4} \text { in } \\
\text { precipitate cake }\end{array}$ & $\begin{array}{l}\text { Condition is } \\
\text { normal }\end{array}$ & $\begin{array}{l}\text { Base and } \\
\text { contingency } \\
\text { cases modeled } \\
\text { with Pu metal } \\
\text { and water } \\
\text { (bc) }\end{array}$ \\
\hline 32 & $\begin{array}{l}\text { Drying precipitate in a } \\
\text { furnace boat on hotplate } \\
\text { while moving a full furnace } \\
\text { boat too close to hotplate } \\
\text { (Geometry/Interaction) }\end{array}$ & Increased interaction & $\begin{array}{l}\text { Procedures, } \\
\text { physical layout of } \\
\text { glovebox } 3\end{array}$ & $\begin{array}{l}\text { Bound by extra } \\
\text { boat stacked on } \\
\text { boat rack } \\
\text { (cc4) }\end{array}$ \\
\hline 33 & $\begin{array}{l}\text { Drying precipitate in a } \\
\text { furnace boat on hotplate with } \\
\text { increased reflection due to } \\
\text { operator's hands being near } \\
\text { the boat (Reflection) }\end{array}$ & Increased reflection & $\begin{array}{l}\text { Operators } \\
\text { normally use tongs } \\
\text { to move boats } \\
\text { inside the } \\
\text { glovebox }\end{array}$ & $\begin{array}{l}\text { Base and } \\
\text { contingency } \\
\text { cases modeled } \\
\text { with } 1 \text { in. water } \\
\text { reflection } \\
\text { around boat on } \\
\text { hotplate }\end{array}$ \\
\hline 34 & $\begin{array}{l}\text { Drying precipitate in a } \\
\text { furnace boat with increased } \\
\text { moderation due to out-of- } \\
\text { specification chemical } \\
\text { addition }\end{array}$ & $\begin{array}{l}\text { Increased range of } \\
\mathrm{H} / \mathrm{Pu} \text { (moderation) }\end{array}$ & $\begin{array}{l}\text { Small volume of } \\
\text { furnace boat, } \\
\text { procedures }\end{array}$ & $\begin{array}{l}\text { Base and } \\
\text { contingency } \\
\text { cases modeled } \\
\text { with Pu metal } \\
\text { and water at } \\
\text { max } \\
\text { moderation } \\
(\mathrm{H} / \mathrm{X})\end{array}$ \\
\hline 35 & $\begin{array}{l}\text { Drying a more highly } \\
\text { concentrated precipitate than } \\
\text { expected in a furnace boat } \\
\text { due to out-of-specification } \\
\text { chemical addition }\end{array}$ & $\begin{array}{l}\text { Increased Pu mass in } \\
\text { furnace boat }\end{array}$ & $\begin{array}{l}\text { Small volume of } \\
\text { furnace boat, } \\
\text { procedures, } \mathrm{Pu} \\
\text { limit on } 3 \\
\text { precipitator tanks, } \\
\text { control of } \\
\text { chemical addition, } \\
\text { procedures. }\end{array}$ & $\begin{array}{l}\text { An increase in } \\
\text { concentration } \\
\text { will reduce the } \\
\mathrm{H} / \mathrm{X} \text { ratio } \\
\text { resulting in a } \\
\text { less reactive } \\
\text { system when } \\
\text { keeping mass } \\
\text { constant. }\end{array}$ \\
\hline
\end{tabular}




\begin{tabular}{|c|c|c|c|c|}
\hline \multicolumn{5}{|c|}{$\begin{array}{l}\text { Hazard Assessment of "Magnesium Hydroxide Precipitation Process" } \\
\text { Activity Assessment Team: D. M. Carson, H. L. Chang, D. Clapp, J. S. Lan, E. M. Miller, } \\
\text { A. L. Ramble, L. J. Rosane, H. Toffer }\end{array}$} \\
\hline $\begin{array}{c}\text { Item } \\
\#\end{array}$ & Condition & Hazard/Consequence & Safeguard & Resolution \\
\hline 36 & $\begin{array}{l}\text { Drying a larger volume of } \\
\text { precipitate than expected in a } \\
\text { furnace boat due to an excess } \\
\text { amount of precipitate loaded } \\
\text { into the boat }\end{array}$ & $\begin{array}{l}\text { Increased Pu mass in } \\
\text { furnace boat }\end{array}$ & $\begin{array}{l}\text { Small volume of } \\
\text { furnace boat, } \\
\text { procedures }\end{array}$ & $\begin{array}{l}\text { Bound by } \\
\text { overloaded boat } \\
\text { in boat rack } \\
\text { (cc3) }\end{array}$ \\
\hline 37 & $\begin{array}{l}\text { Pumping solution into } \\
\text { filtrate tanks with a high } \\
\text { loading of Pu in the } \\
\text { polishing filters (Mass - } \\
\text { HIGH) }\end{array}$ & Increased Pu mass & $\begin{array}{l}\text { Small volume of } \\
\text { polishing filters, } \\
\text { procedures, } \mathrm{Pu} \\
\text { limit on } 3 \\
\text { precipitator tanks, } \\
\text { control of } \\
\text { chemical addition. }\end{array}$ & $\begin{array}{l}\text { Due to smaller } \\
\text { size and greater } \\
\text { separation from } \\
\text { other } \\
\text { fissionable } \\
\text { material, } \\
\text { considered } \\
\text { bound by } \\
\text { vacuum tank/ } \\
\text { phase separator } \\
\text { at } 40 \\
\text { and } 65 \mathrm{~g} / \mathrm{L} \\
\text { (cc2a and } \mathrm{cc} 2 \mathrm{~b} \text { ) }\end{array}$ \\
\hline 38 & $\begin{array}{l}\text { Pumping } \mathrm{Pu}\left(\mathrm{NO}_{3}\right)_{4} \text { solution } \\
\text { into filtrate tanks without } \\
\text { precipitation or filtering } \\
\text { (Mass - AS WELL AS) }\end{array}$ & Increased Pu mass & Procedures & $\begin{array}{l}\text { N/A for } \\
\text { Glovebox } 3\end{array}$ \\
\hline 39 & $\begin{array}{l}\text { Pumping filtrate into filtrate } \\
\text { tanks with an interaction of } \\
\text { the filtrate with items of } \\
\text { opposite side of wall from } \\
\text { glovebox } 4 \text { (Interaction) }\end{array}$ & Increased interaction & $\begin{array}{l}\text { Procedures, } \\
\text { markings on floor } \\
\text { on other side of } \\
\text { wall from } \\
\text { glovebox } 4\end{array}$ & $\begin{array}{l}\text { N/A for } \\
\text { Glovebox } 3\end{array}$ \\
\hline 40 & $\begin{array}{l}\text { Pumping filtrate into filtrate } \\
\text { tanks with increased } \\
\text { reflection due to operator's } \\
\text { hands being around the } \\
\text { filtrate tanks (Reflection) }\end{array}$ & Increased reflection & $\begin{array}{l}\text { Limited number of } \\
\text { gloves in area of } \\
\text { filtrate tanks }\end{array}$ & $\begin{array}{l}\text { N/A for } \\
\text { Glovebox } 3\end{array}$ \\
\hline 41 & $\begin{array}{l}\text { Pumping } \mathrm{Pu}\left(\mathrm{NO}_{3}\right)_{4} \text { solution } \\
\text { at } 450 \mathrm{~g} / \mathrm{L} \text { into filtrate tanks } \\
\text { without precipitation or } \\
\text { filtering (Moderation) }\end{array}$ & Increased moderation & Procedures & $\begin{array}{l}\text { N/A for } \\
\text { Glovebox } 3\end{array}$ \\
\hline
\end{tabular}




\begin{tabular}{|c|c|c|c|c|}
\hline \multicolumn{5}{|c|}{$\begin{array}{l}\text { Hazard Assessment of "Magnesium Hydroxide Precipitation Process" } \\
\text { Activity Assessment Team: D. M. Carson, H. L. Chang, D. Clapp, J. S. Lan, E. M. Miller, } \\
\text { A. L. Ramble, L. J. Rosane, H. Toffer }\end{array}$} \\
\hline $\begin{array}{c}\text { Item } \\
\#\end{array}$ & Condition & Hazard/Consequence & Safeguard & Resolution \\
\hline 42 & $\begin{array}{l}\text { Pumping Pu(NO} 3)_{4} \text { solution } \\
\text { at } 450 \mathrm{~g} / \mathrm{L} \text { into filtrate tanks } \\
\text { without precipitation or } \\
\text { filtering (Concentration) }\end{array}$ & $\begin{array}{l}\text { Increased Pu solution } \\
\text { concentration }\end{array}$ & Procedures & $\begin{array}{l}\text { N/A for } \\
\text { Glovebox } 3\end{array}$ \\
\hline 43 & $\begin{array}{l}\text { Filtrate overflows TK- } \\
\text { 004/TK-006 and reaches the } \\
\text { eductor, leading to solution } \\
\text { sprays inside glovebox } 3 \\
\text { (Volume - HIGH) }\end{array}$ & $\begin{array}{l}\text { Increased solution } \\
\text { volume }\end{array}$ & Procedures & $\begin{array}{l}\text { Not credible for } \\
\text { solution sprays } \\
\text { inside } \\
\text { Glovebox } 3 \text { per } \\
\text { discussion in } \\
\text { Section } 3.4\end{array}$ \\
\hline 44 & $\begin{array}{l}\text { A seismic event causes the } \\
\text { furnace boat rack to fail, } \\
\text { allowing furnace boats to fall } \\
\text { together (External events - } \\
\text { Seismic) }\end{array}$ & Decreased spacing & $\begin{array}{l}\text { Glovebox } 3 \text { is } \\
\text { seismically } \\
\text { qualified, boat } \\
\text { rack is seismically } \\
\text { qualified. }\end{array}$ & $\begin{array}{l}\text { Bound by extra } \\
\text { boat stacked on } \\
\text { boat rack } \\
\text { (cc4) }\end{array}$ \\
\hline 45 & $\begin{array}{l}\text { A fire sets off fire sprinklers } \\
\text { in the room and the fire } \\
\text { water enters the glovebox } \\
\text { through burned-through top } \\
\text { glovebox windows (External } \\
\text { events - Fire sprinklers) }\end{array}$ & Increased reflection & $\begin{array}{l}\text { Criticality drain in } \\
\text { glovebox } 3 \text {, fire } \\
\text { sprinklers exist } \\
\text { only in room, but } \\
\text { glove-boxes have } \\
\text { a dry chemical fire } \\
\text { suppression } \\
\text { system. }\end{array}$ & $\begin{array}{l}\text { Fire scenario } \\
(\operatorname{cc} 6)\end{array}$ \\
\hline 46 & $\begin{array}{l}\text { People surround the } \\
\text { glovebox (top, sides, and } \\
\text { bottom) causing increased } \\
\text { reflection (External events - } \\
\text { People) }\end{array}$ & Increased reflection & $\begin{array}{l}\text { External } \\
\text { dimensions of } \\
\text { glovebox }\end{array}$ & $\begin{array}{l}\text { Base and } \\
\text { contingency } \\
\text { cases model } \\
12 \text { in. around } \\
\text { sides and } 6 \text { in. } \\
\text { on bottom of } \\
\text { glovebox }\end{array}$ \\
\hline 47 & $\begin{array}{l}\text { Construction activities } \\
\text { damage a water line, leading } \\
\text { to water falling and pooling } \\
\text { on top of the glovebox }\end{array}$ & Increased reflection & $\begin{array}{l}\text { Construction job } \\
\text { planning }\end{array}$ & $\begin{array}{l}\text { Base and } \\
\text { contingency } \\
\text { cases model } \\
1 \text { in. water on } \\
\text { top of glovebox }\end{array}$ \\
\hline
\end{tabular}




\begin{tabular}{|c|c|c|c|c|}
\hline \multicolumn{5}{|c|}{ Hazard Assessment of "Magnesium Hydroxide Precipitation Process" } \\
Activity Assessment Team: D. M. Carson, H. L. Chang, D. Clapp, J. S. Lan, E. M. Miller, \\
A. L. Ramble, L. J. Rosane, H. Toffer
\end{tabular}


HNF-6537 REV. 0

APPENDIX E - MCNP MODEL FIGURES

E-1 
HNF-6537 REV. 0

This page intentionally left blank.

E-2 
HNF-6537 REV. 0

\begin{tabular}{|c|c|}
\hline $\begin{array}{l}\text { Material } \\
\text { Numbers }\end{array}$ & Material Description \\
\hline 1 & 6 inches of $\mathrm{Pu}$ solid $\left(3 \mathrm{~g} \mathrm{Pu} / \mathrm{cm}^{3}\right.$ in $\left.\mathrm{PuO}_{2}\right)$ at tank bottom \\
\hline 7 & Water \\
\hline 8 & air \\
\hline 11 & Stainless Steel \\
\hline 14 & Reflector Brick zone \\
\hline 15 & Polyethylene \\
\hline 21 & $40 \mathrm{~g} \mathrm{Pu} / \mathrm{L}$ in $\mathrm{Pu}\left(\mathrm{NO}_{3}\right)_{4}$ \\
\hline 22 & $50 \mathrm{~g} \mathrm{Pu} / \mathrm{L}$ in $\mathrm{Pu}\left(\mathrm{NO}_{3}\right)_{4}$ \\
\hline 23 & $60 \mathrm{~g} \mathrm{Pu} / \mathrm{L}$ in $\mathrm{Pu}\left(\mathrm{NO}_{3}\right)_{4}$ \\
\hline 24 & $3 \mathrm{~g} \mathrm{Pu} / \mathrm{cm}^{3}$ in $\mathrm{PuO}_{2}$ \\
\hline 25 & $1 \times 10^{-3} \mathrm{~g} / \mathrm{L}$ Pu Metal \\
\hline 26 & $2.5 \mathrm{~kg} \mathrm{Pu}$ in $\mathrm{PuO}_{2}$ fill water in interstitial space of a $2.3 \mathrm{~L}$ boat \\
\hline 27 & $2.5 \mathrm{~kg} \mathrm{Pu}$ in $\mathrm{PuO}_{2}$ with $50-50 \%$ of water in vacuum filter basin \\
\hline 28 & $1.5 \mathrm{~kg} \mathrm{Pu}$ in $0.5 \mathrm{~L}$ sweeps with $3 \mathrm{~g} \mathrm{Pu} / \mathrm{cm}^{3}$ \\
\hline 29 & $100 \mathrm{~g} \mathrm{Pu} / \mathrm{L}$ in $\mathrm{Pu}\left(\mathrm{NO}_{3}\right)_{4}$ \\
\hline 30 & $1 \mathrm{~g} \mathrm{Pu} / \mathrm{L}$ in $\mathrm{PuO}_{2}$ \\
\hline 31 & $2.75 \mathrm{~kg} \mathrm{Pu}$ in $\mathrm{PuO}_{2}$ fill water in interstitial space of a $2.3 \mathrm{~L}$ boat \\
\hline 32 & $250 \mathrm{~g} \mathrm{Pu} / \mathrm{L}$ in $\mathrm{Pu}\left(\mathrm{NO}_{3}\right)_{4}$ for aggregate of unspaced containers \\
\hline
\end{tabular}


HNF-6537 REV, 0

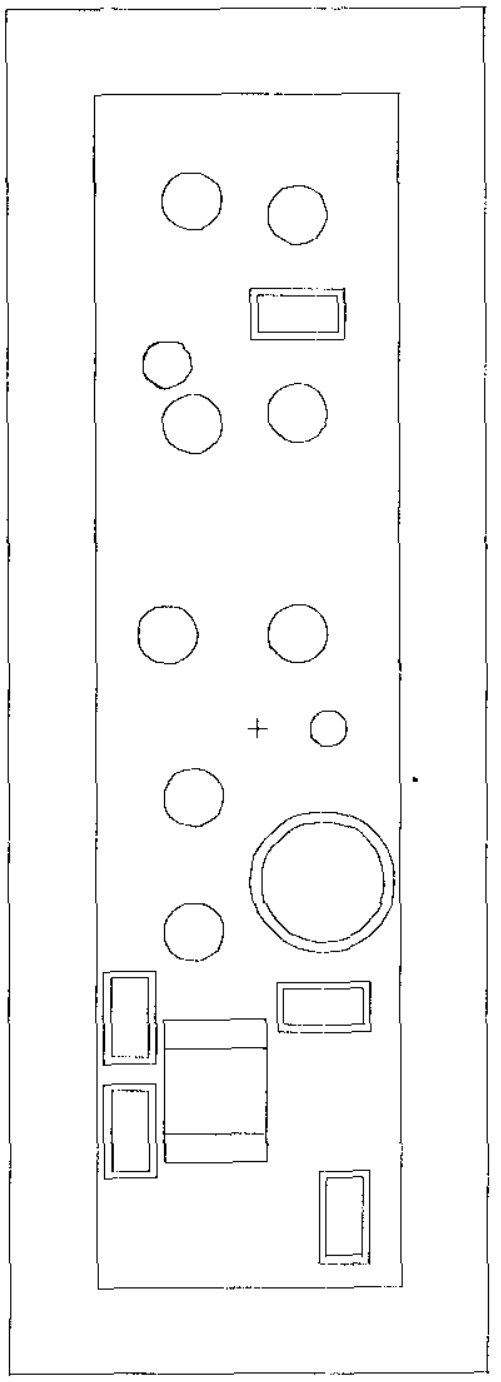

E-4 
HNF-6537 REV. 0

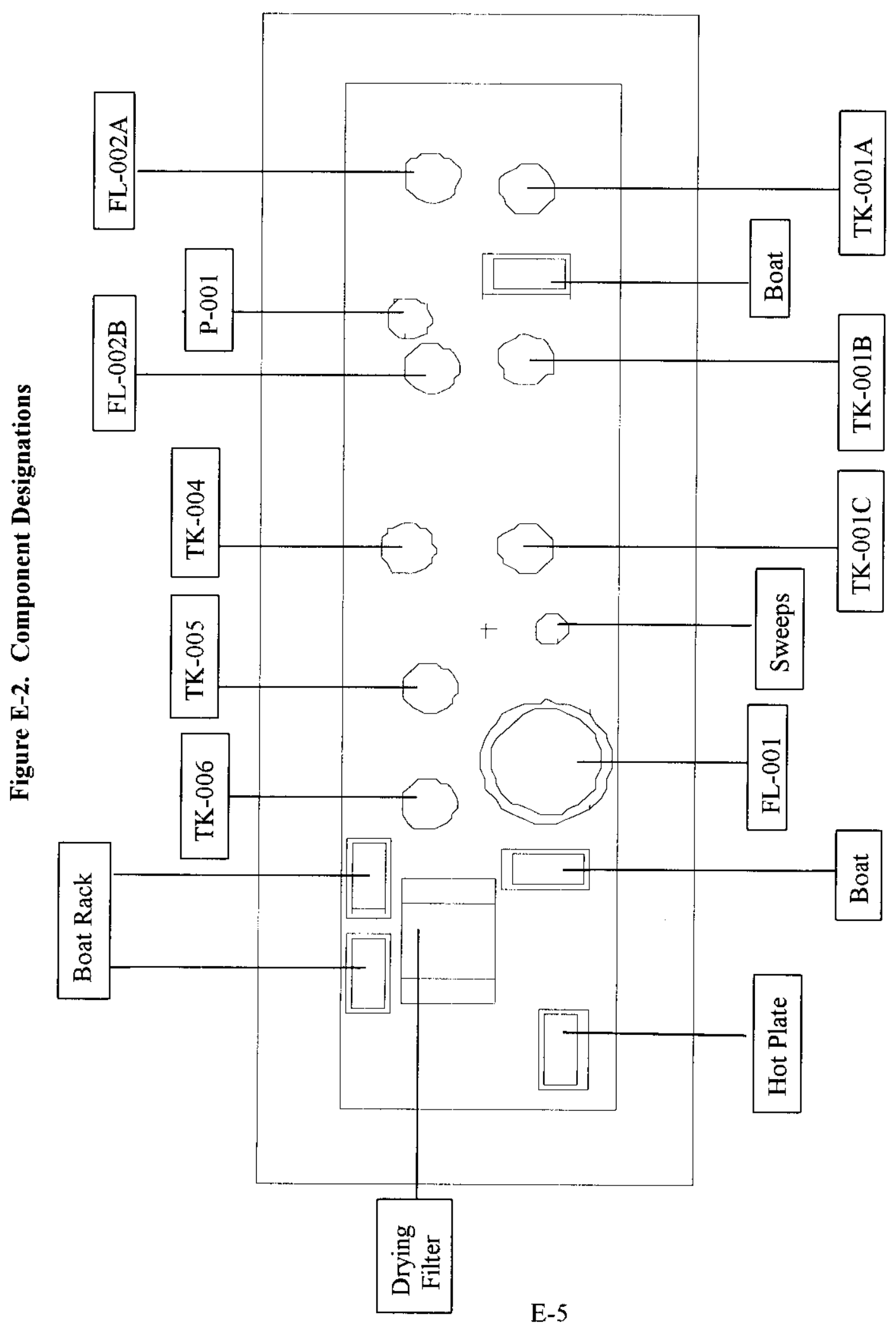


HNF-6537 REV. 0

Figure E-3. Base Case-bcx30.ps

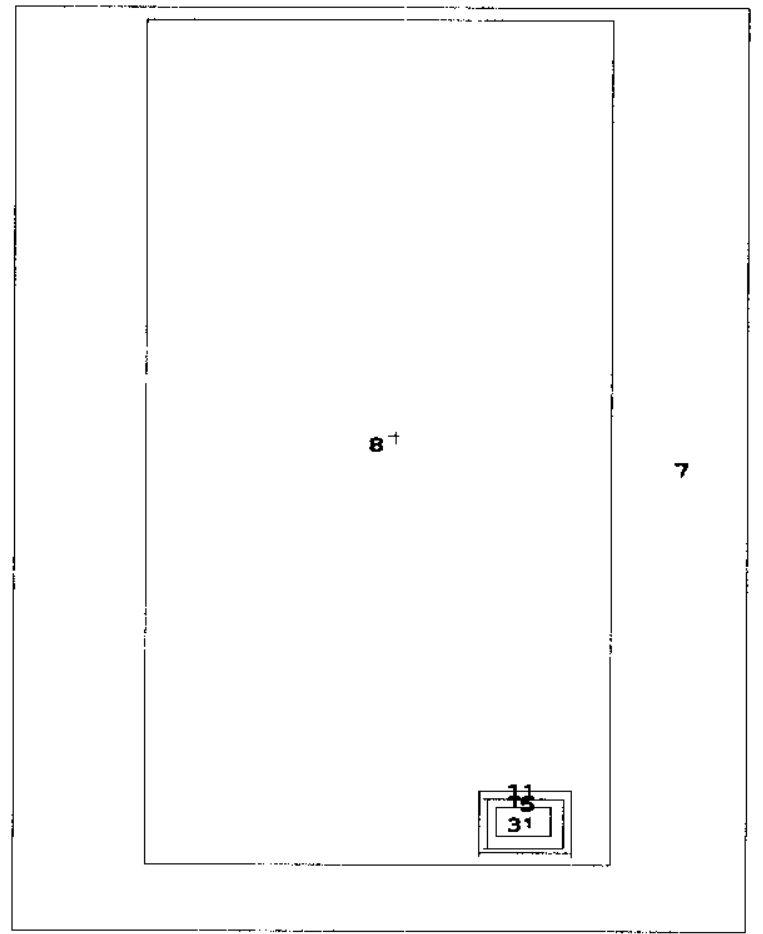

Figure E-4. Base Case- bcx50.ps

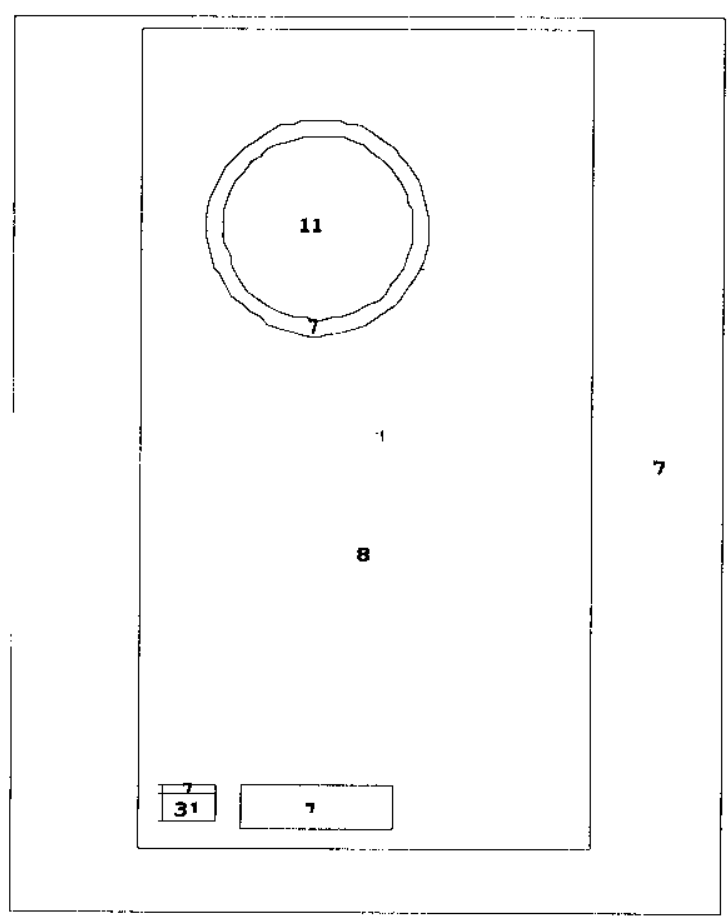

E-6 
HNF-6537 REV. 0

Figure E-5. Base Case - bcx130.ps

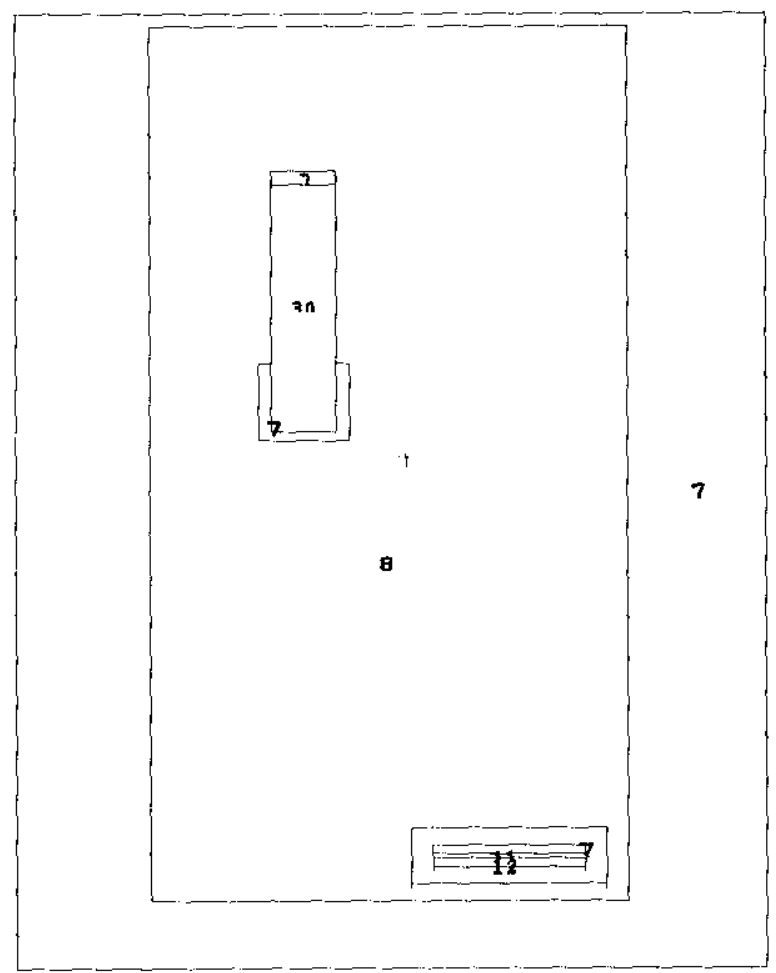

Figure E-6. Base Case - bcx230.ps

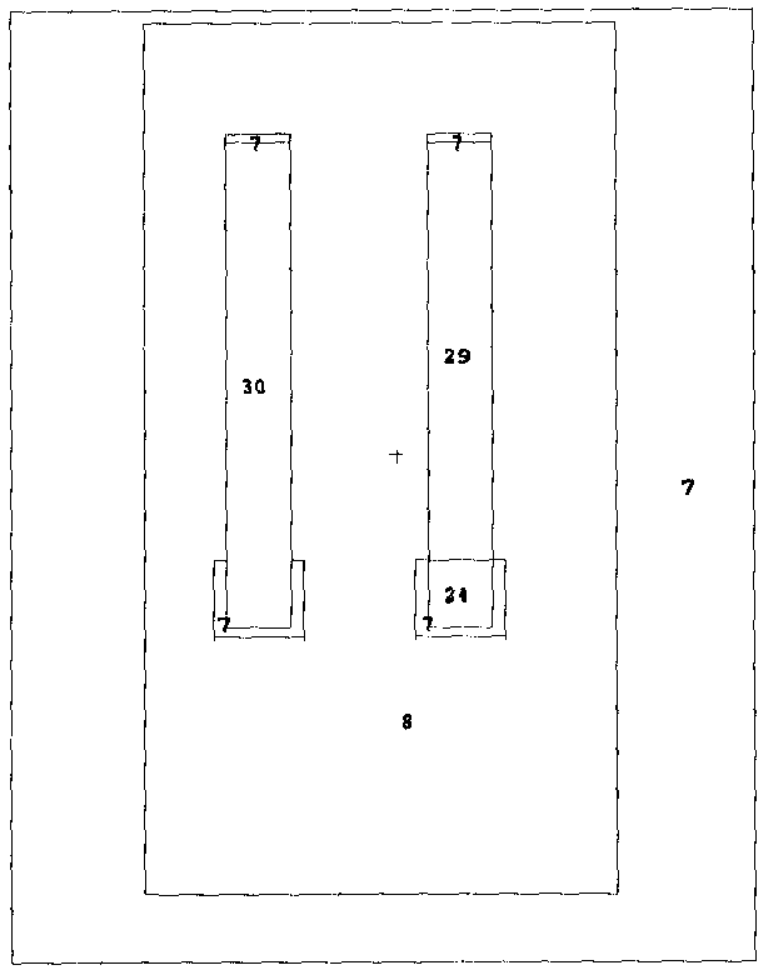

E-7 


\section{HNF-6537 REV. 0}

Figure E-7. Base Case - bcx330.ps

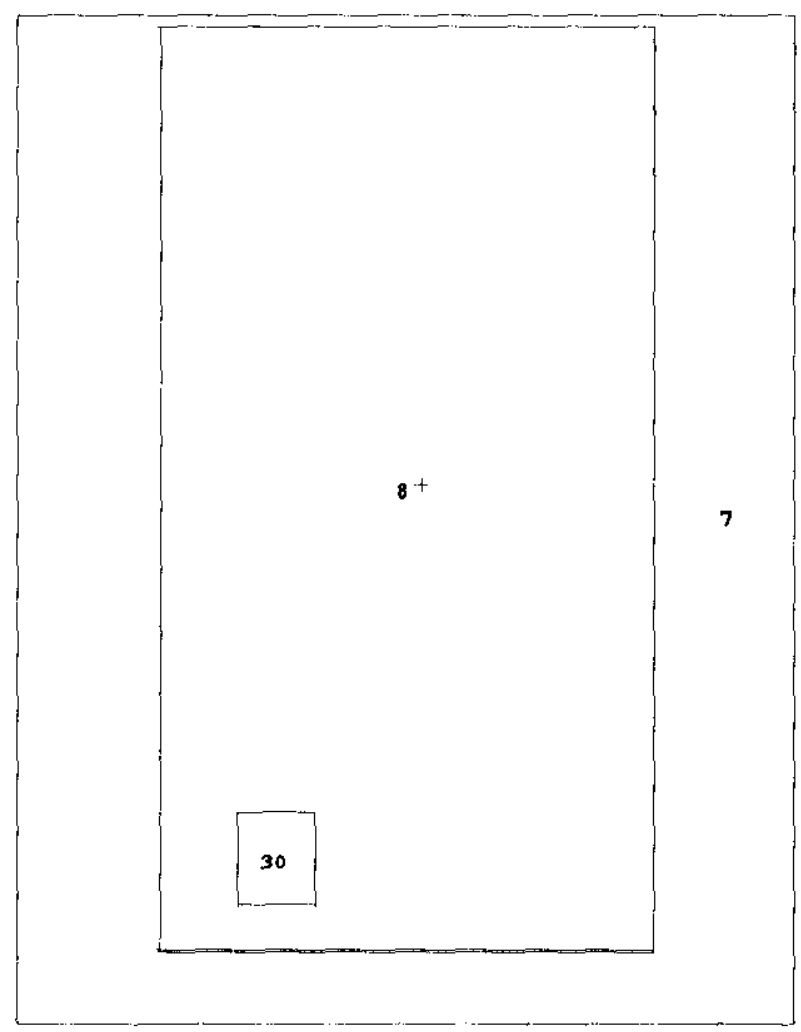

Figure E-8. Base Case - bcy25.ps

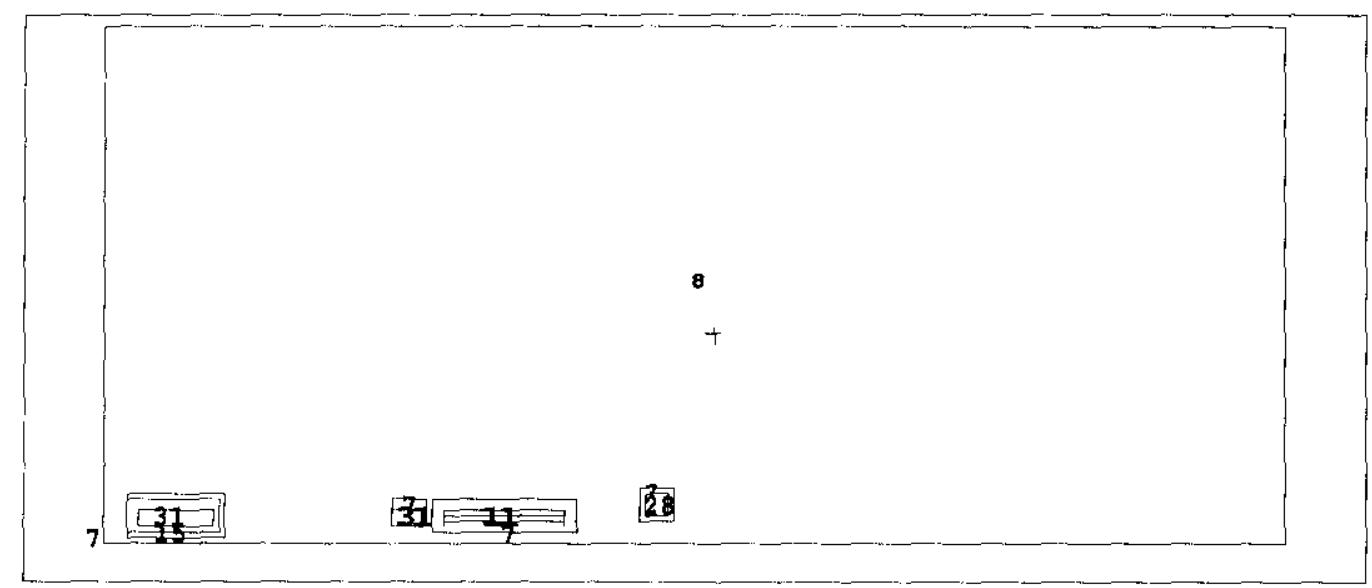


HNF-6537 REV. 0

Figure E-9. Base Case - bcy30.ps

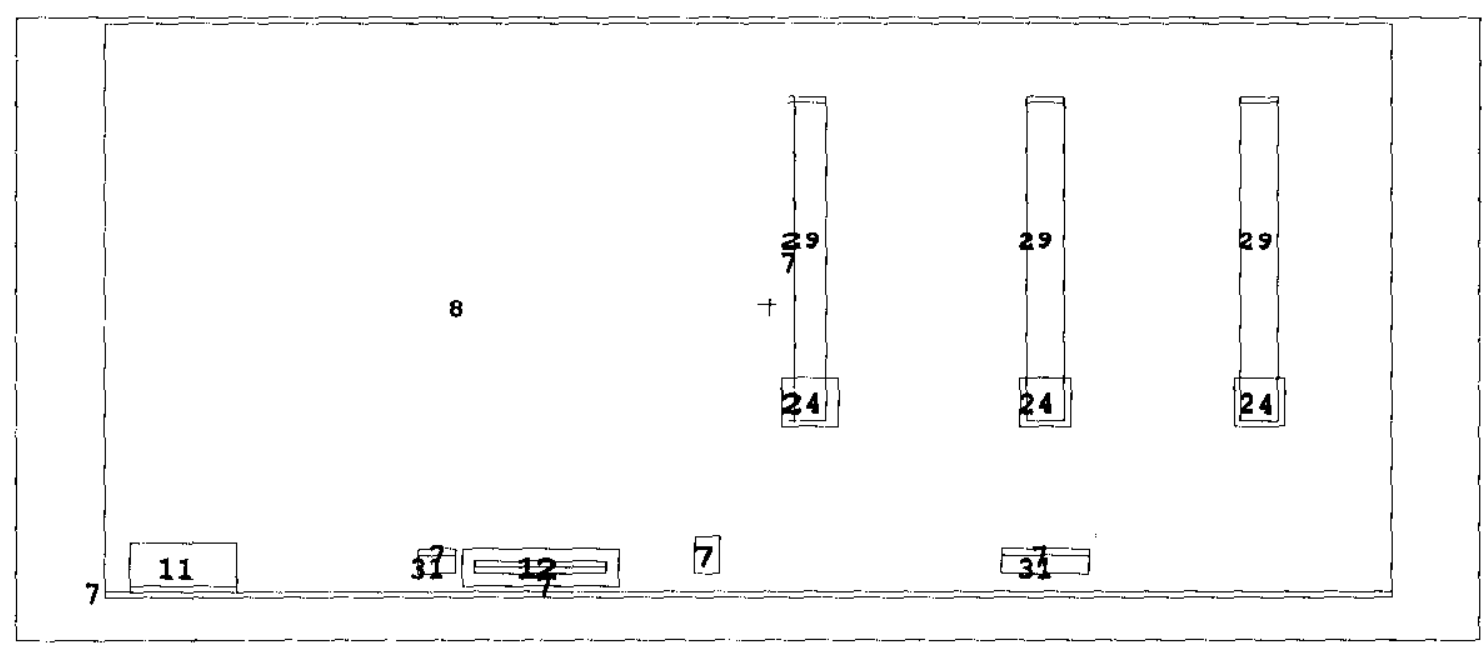

Figure E-10. Base Case - bcy75.ps

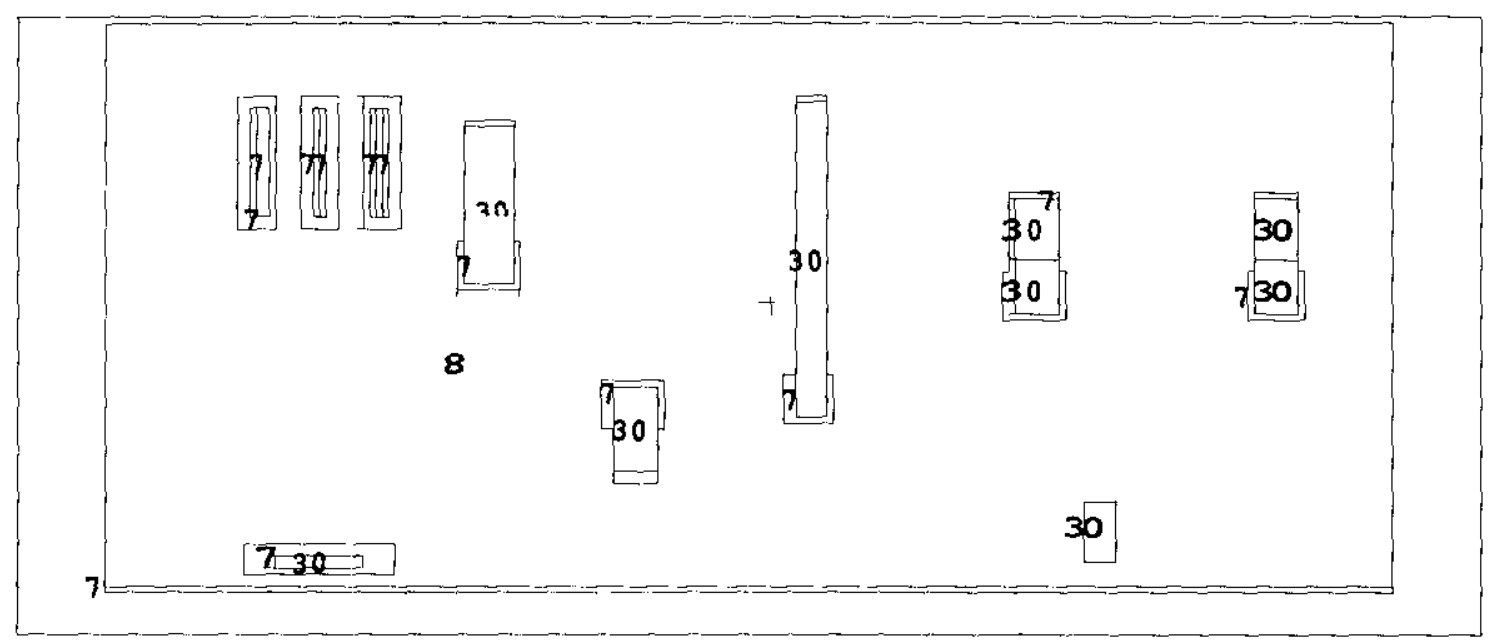


HNF-6537 REV. 0

Figure E-11. Base Case - bcz11.ps

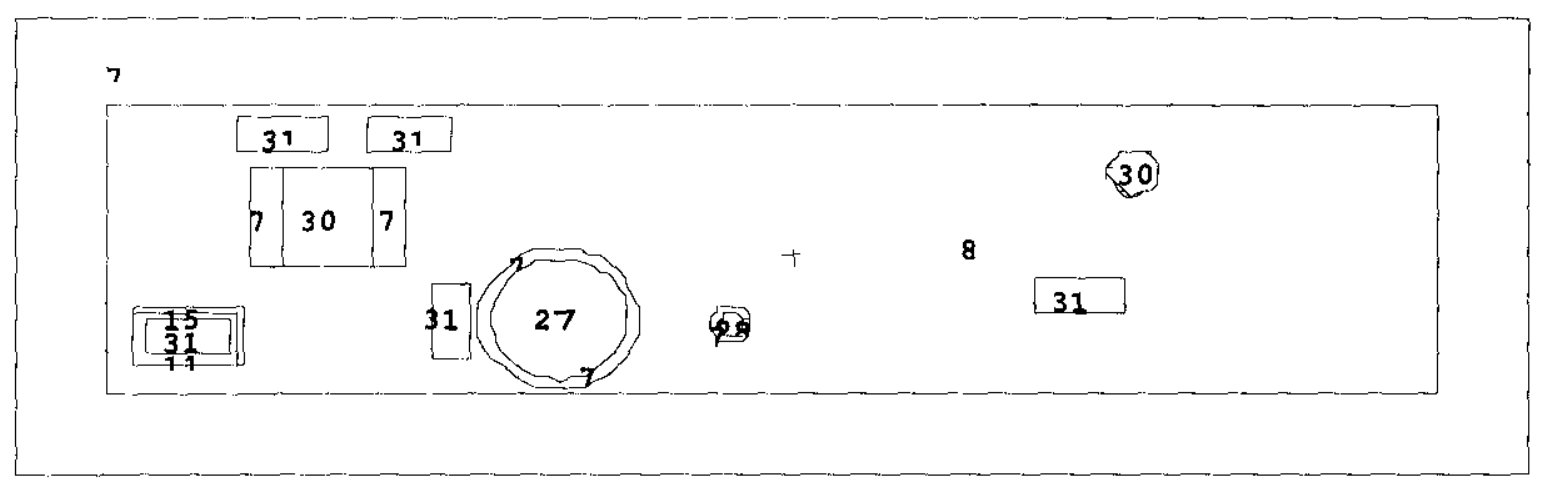

Figure E-12. Base Case - bcz30.ps

7

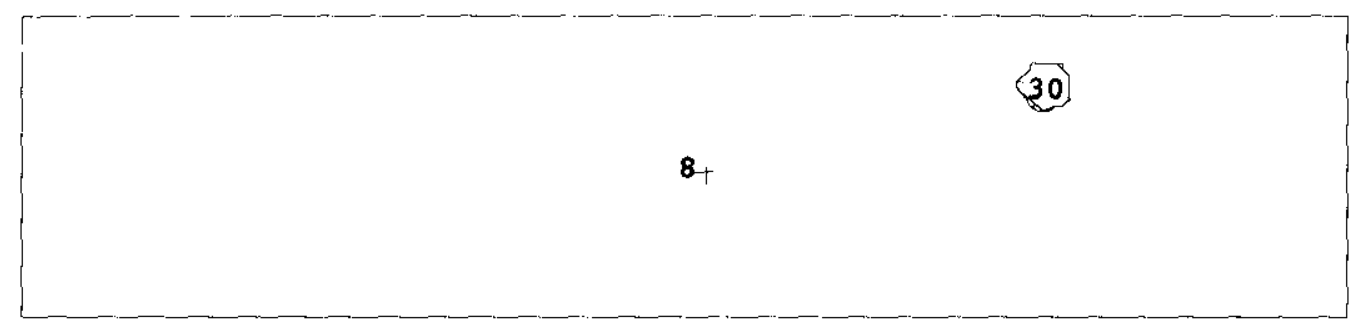

E-10 
HNF-6537 REV. 0

Figure E-13. Base Case - bcz70.ps

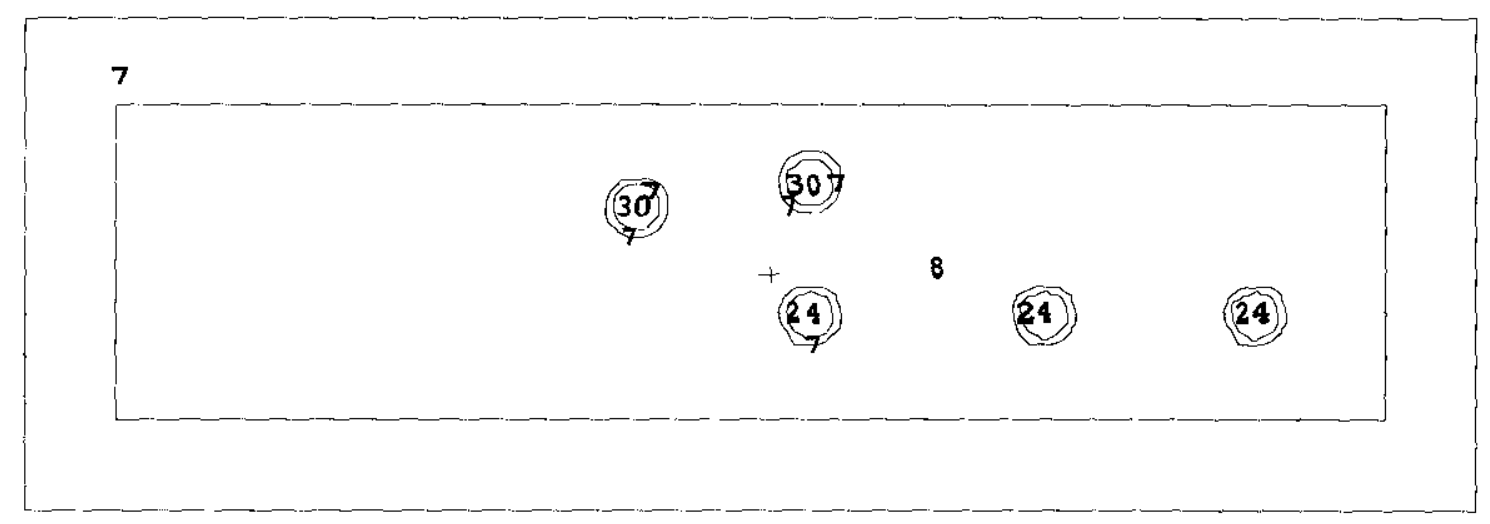

Figure E-14. Base Case - bcz125.ps

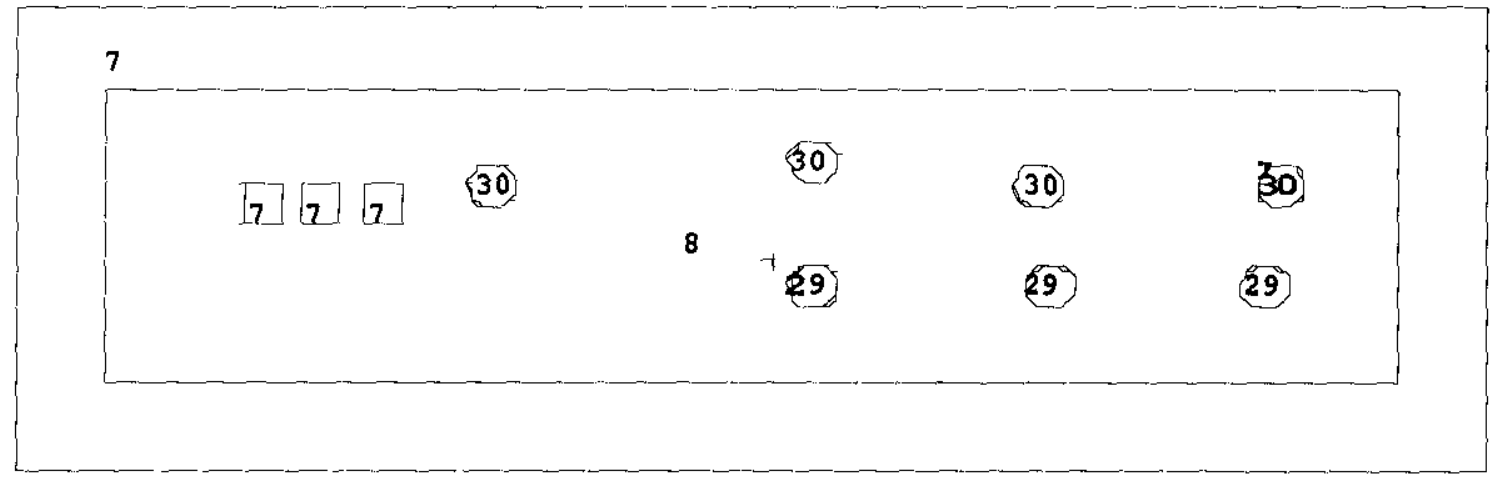


Figure E-15. Base Case - bcz135.ps

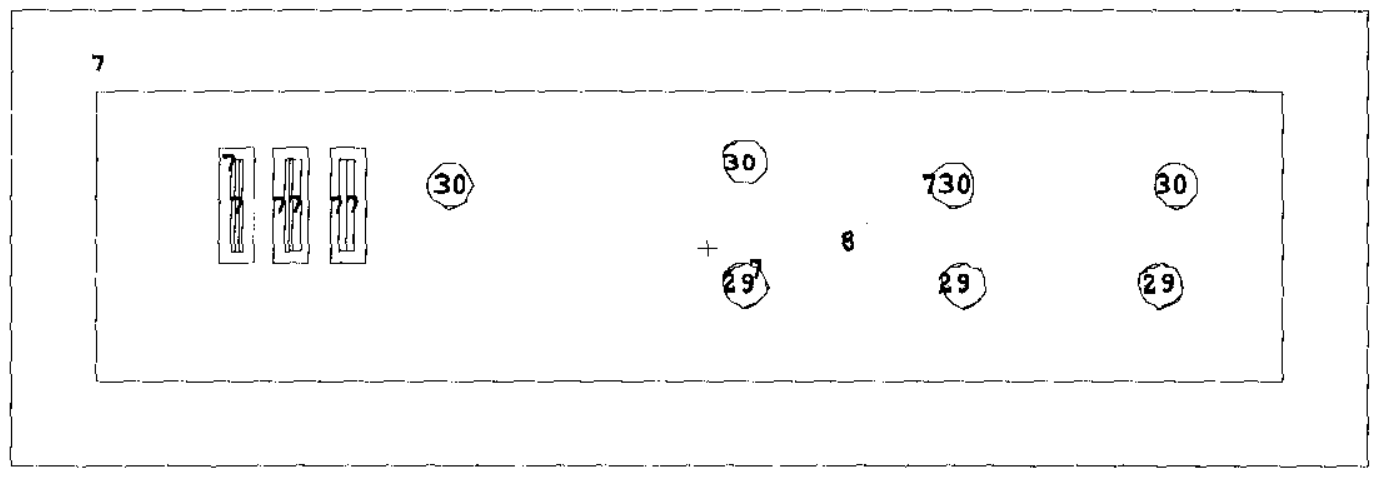

Figure E-16. Loss of Spacing Between Boats - cc10xy.ps

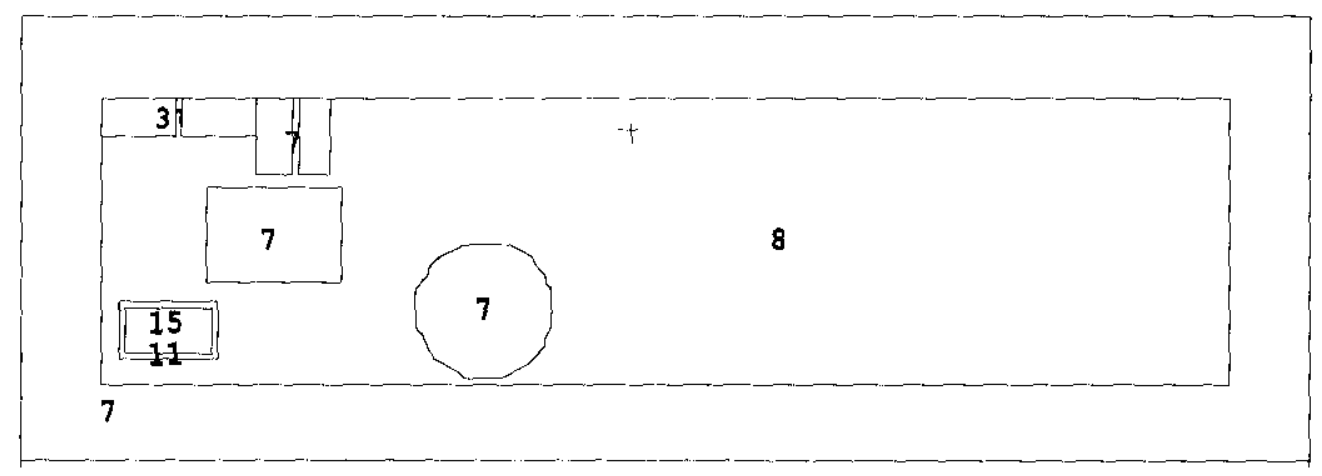


HNF-6537 REV. 0

Figure E-17. Aggregate of Unspaced Container - cwcc7yz.ps

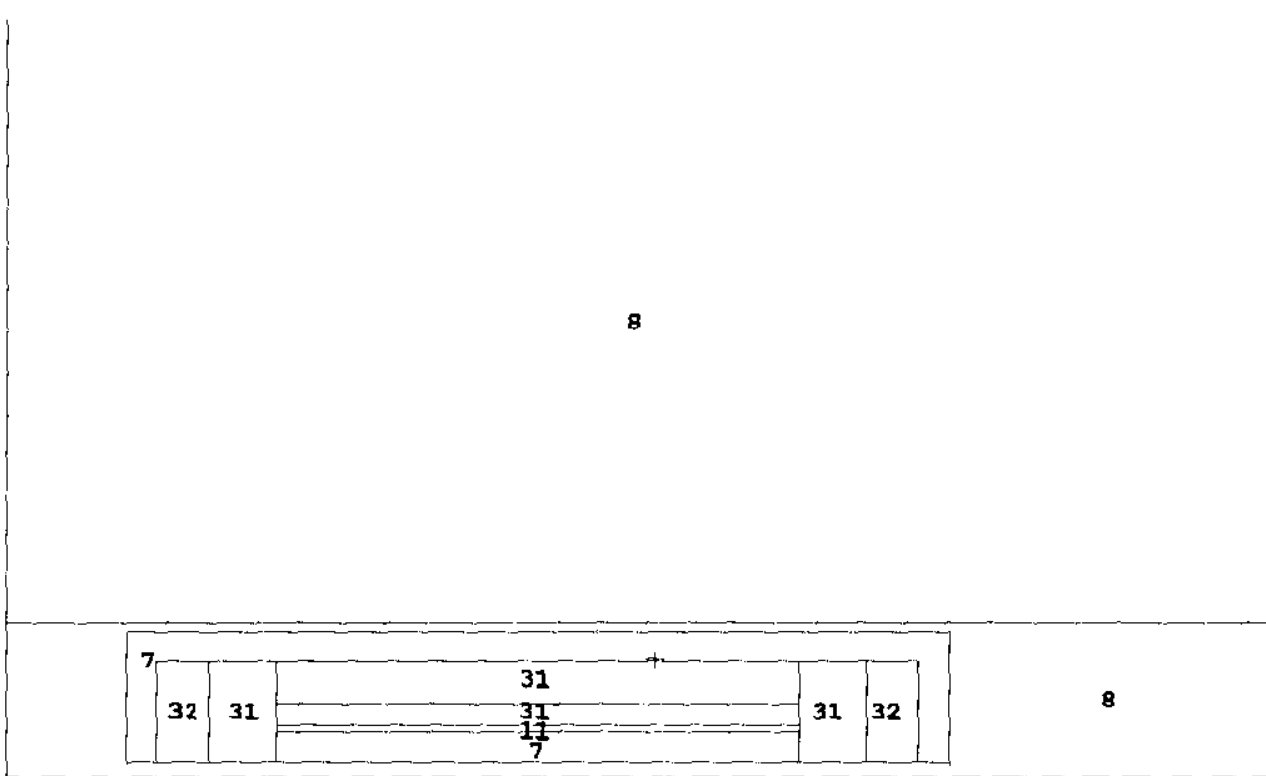

7 
HNF-6537 REV. 0

Figure E-18. Seismic with Intact Tanks - ncs2z100.ps

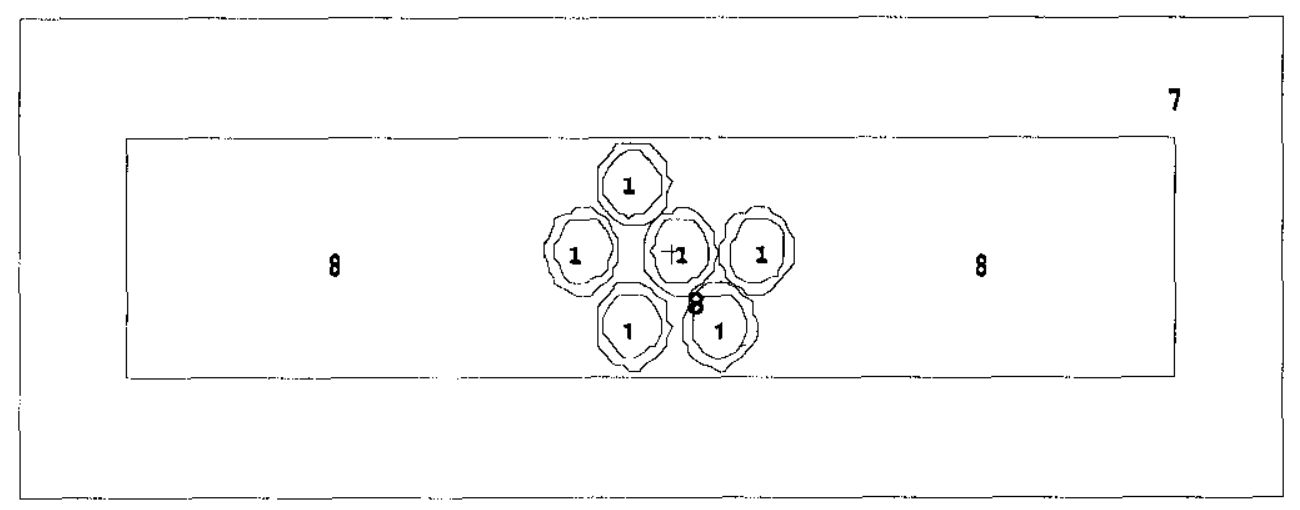

Figure E-19. Plutonium Container Against the Glovebox - cc7mat.ps

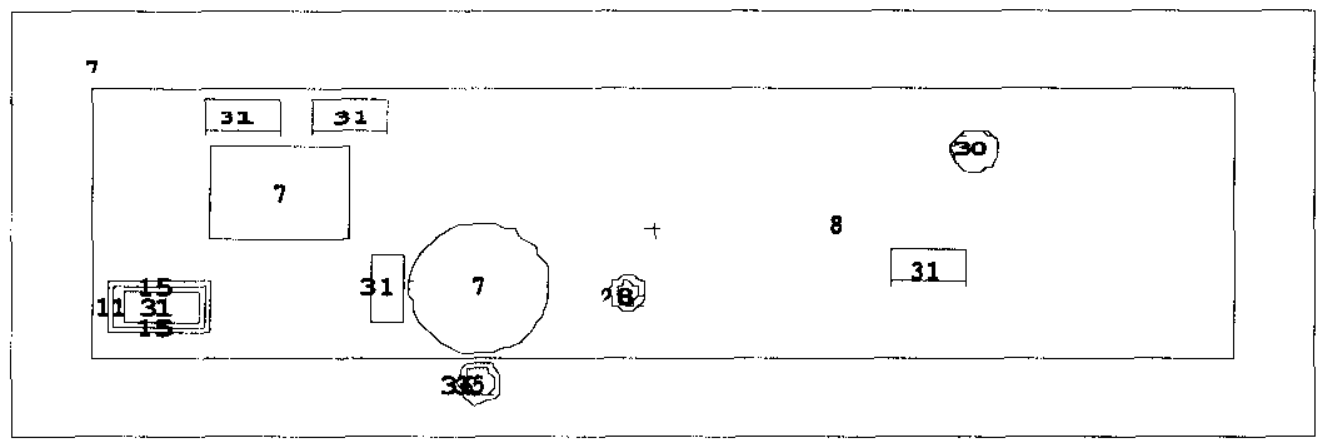


HNF-6537 REV. 0

APPENDIX F - SAMPLE MEASUREMENTS

F-1 
HNF-6537 REV. 0

This page intentionally left blank.

F-2 
HNF-6537 REV. 0

\begin{tabular}{|c|c|c|c|c|}
\hline Items & $\begin{array}{c}\text { Drawing } \\
\text { Dimension }\end{array}$ & $\begin{array}{c}\text { Analysis } \\
\text { Dimension }\end{array}$ & $\begin{array}{c}\text { As- } \\
\text { Measured } \\
\text { Dimension }\end{array}$ & Conclusion \\
\hline $\begin{array}{c}\text { Spacing Between } \\
\text { TK-001A to TK-001B }\end{array}$ & $28 "$ & $27 "$ & $29.5^{\prime \prime}$ & $\begin{array}{c}\text { Analysis } \\
\text { Dimension < } \\
\text { As-Measured }\end{array}$ \\
\hline $\begin{array}{c}\text { Spacing Between } \\
\text { TK-001B to TK-001C }\end{array}$ & $31 "$ & $30 "$ & $31 "$ & $\begin{array}{c}\text { Analysis } \\
\text { Dimension }< \\
\text { As-Measured }\end{array}$ \\
\hline $\begin{array}{c}\text { Spacing Between } \\
\text { TK-001C to TK-004 }\end{array}$ & $18 "$ & $18^{\prime \prime}$ & $19.5^{\prime \prime}$ & $\begin{array}{c}\text { Analysis } \\
\text { Dimension }< \\
\text { As-Measured }\end{array}$ \\
\hline $\begin{array}{c}\text { Spacing Between } \\
\text { TK-0015 to TK-0016 }\end{array}$ & $19 "$ & $18 "$ & $19 "$ & $\begin{array}{c}\text { Analysis } \\
\text { Dimension }< \\
\text { As-Measured }\end{array}$ \\
\hline
\end{tabular}


HNF-6537 REV. 0

This page intentionally left blank.

F-4 
HNF-6537 REV. 0

APPENDIX G - COMPONENT SENSITIVITY CALCULATIONS 


\section{HNF-6537 REV. 0}

This page intentionally left blank.

G-2 


\section{G. 1 Normal Case Study}

Normal cases nca and ncb (Table G-1) calculate system interaction for the whole glovebox. Based on the fissionable material contents under the normal operation condition described in Table 2-2, Case nca differs from case ncb only in the contents of the sweeps can. In case nca, the sweeps can contains dense plutonium $\left(1.5 \mathrm{~kg}\right.$ of $3 \mathrm{~g} \mathrm{Pu} / \mathrm{cm}^{3}$ in $\mathrm{PuO}_{2}, \mathrm{H} / \mathrm{X}=7.5$ ) while ncb maximizes the moderation ( $1091 \mathrm{~g}$ of $\mathrm{Pu}$ in water with an $\mathrm{H} / \mathrm{X}=20$ ). The maximum moderation case was modeled conservatively as theoretical density plutonium in water. The sweeps can model that gives the greater reactive base case is to be used in further calculations. The result shows that the difference between the two calculated neutron multiplication factors is within their statistical uncertainties at the $95 \%$ confidence level. Case nca was arbitrarily chosen for the rest of the analysis. The results $\left(\mathrm{k}_{\mathrm{eff}} \mathrm{s}<0.8\right)$ show that the safety control limits established in the preliminary design (section 4-1) for equipment layout were adequate for criticality safety. These two cases do not show which components are the most reactive or what interactions between equipment are the most important.

Table G-1 lists $\mathrm{k}_{\mathrm{eff}}$ for various components (tanks, filter, boats etc.) alone and in combinations. These calculations identify the most reactive equipment. Changes to the mass and reflection of other items may not change the entire system $k_{\text {eff }}$ unless there is significant interaction between the items in the glovebox. Case ncal to nca6 gives single item $\mathrm{k}_{\text {eff }} \mathrm{s}$. Case nca7 to ncall gives $k_{\text {eff }}$ 's on groupings of equipment. Case nca12 analyzes the boat on the hot plate alone. Case ncbbo calculates the $\mathrm{k}_{\mathrm{eff}}$ for the whole glovebox. Cases nca 1 and nca 3 give the results for one and three precipitation tanks (12 liters of $50 \mathrm{~g} \mathrm{Pu} / \ell$ per tank), respectively. Comparing these two cases shows that the required spacing does isolate the fissionable material in the tanks adequately. Cases nca 2 and nca4 are the corresponding results when the tanks are surrounded by 1 in. of water. Although the $k_{\text {eff }}$ 's values are low, the differences between the "with" and the "without" water reflection cases are substantial. Cases nca5 and nca6 show the very limited reactivity of either the vacuum filter basin or loaded boat rack individually.

Case nca7 adds a phase separator tank $\left(1 \times 10^{-3} \mathrm{~g} \mathrm{Pu} / \mathrm{L}\right)$ and 2 polishing filters to the three precipitator tanks. Case nca 8 adds 1 vacuum trap tank and 1 vacuum catch tank $\left(1 \times 10^{-3} \mathrm{~g} \mathrm{Pu} / \mathrm{L}\right)$. Case nca 9 adds the vacuum filter basin ( $1.8 \mathrm{~kg} \mathrm{Pu}$ on filter with $50 \%$ moisture). Case nca 10 adds one furnace boat ( $1.8 \mathrm{~kg}$ Pu metal mixed with water and filling a 2.3 liter volume). The results show very little change from that of the nca 3 case of three precipitation tanks. Case ncal1 shows the dominating contribution of the boat on the hot plate. The boat on the hot plate is to be covered by a steel and borated polyethylene encasement to shield operators from the radiation. The shield increases the neutron reflection around the boat increasing reactivity. In fact, the reflected boat on the hot plate alone (nca12) has a $\mathrm{k}_{\mathrm{eff}}$ compatible to that of the whole system (nca and ncb) when boron is not modeled in the polyethylene. When $5 \%$ boron is included (nca 12) in the polyethylene, the reactivity drops substantially. The neutron absorber is not included in the base case or the contingency analyses for conservatism. 
Table G-1. MCNP Calculational Results for Normal Operation Condition

\begin{tabular}{|c|c|c|c|}
\hline Case ID & Description & $\mathrm{k}_{\mathrm{eff}}$ & $\sigma$ \\
\hline nca & Normal (sweeps can a, see Table 5-I-2) & 0.7905 & 0.00047 \\
\hline $\mathrm{ncb}$ & Normal (sweeps can b, see Table 5-1-2) & $0 . \overline{7917}$ & $0.000 \overline{47}$ \\
\hline ncal & $\begin{array}{l}1 \text { precipitator tank holding } 12 \mathrm{~L} \text { of } 50 \mathrm{~g} \mathrm{Pu} / \mathrm{L} \text { and } \\
\text { without water reflection, no other equipment }\end{array}$ & 0.5859 & 0.00048 \\
\hline nca2 & $\begin{array}{l}1 \text { precipitator tank holding } 12 \mathrm{~L} \text { of } 50 \mathrm{~g} \mathrm{Pu} / \mathrm{L} \text { with } \\
\text { water reflection, no other equipment }\end{array}$ & 0.7671 & 0.00046 \\
\hline nca3 & $\begin{array}{l}3 \text { precipitator tanks each holding } 12 \mathrm{~L} \text { of } 50 \mathrm{~g} \mathrm{Pu} / \mathrm{L} \text { and } \\
\text { without water reflection, no other equipment }\end{array}$ & 0.5952 & 0.00050 \\
\hline nca4 & $\begin{array}{l}3 \text { precipitator tanks each holding } 12 \mathrm{~L} \text { of } 50 \mathrm{~g} \mathrm{Pu} / \mathrm{L} \text { and } \\
\text { with water reflection, no other equipment }\end{array}$ & 0.7774 & 0.00048 \\
\hline nca5 & 1 vacuum filter basin, no other equipment & $0.3866^{*}$ & $0.0006^{*}$ \\
\hline nca6 & 2 boats in storage rack, no other equipment & 0.3155 & 0.00036 \\
\hline nca7 & nca 3 plus 1 phase separator tank and 2 polishing filters & 0.5950 & 0.00048 \\
\hline nca8 & nca 7 plus 1 vacuum trap tank and I vacuum catch tank & 0.5953 & 0.00048 \\
\hline nca 9 & nca 8 plus 1 vacuum filter basin & $0.5958 *$ & 0.00092 \\
\hline ncalo & nca9 plus furnace boat & 0.5966 & 0.00047 \\
\hline ncal1 & nca9 plus 1 hot plate with boat & $0 . \overline{7905}$ & 0.00046 \\
\hline nca 12 & Hot plate with boat alone, no other equipment & $0 . \overline{7899}$ & 0.00045 \\
\hline ncbbo & ncb with borated $(5 \%)$ polyethylene & 0.5950 & 0.00049 \\
\hline
\end{tabular}




\section{G-2. Base Case Study}

Table G-2. MCNP Calculational Results for Base Case

\begin{tabular}{|c|c|c|c|}
\hline Case ID & Description & $\mathrm{k}_{\mathrm{eff}}$ & $\sigma$ \\
\hline $\mathrm{bcl}$ & $\begin{array}{l}\text { (Three precipitation tanks are filled with } 50 \mathrm{~g} \mathrm{Pu} / \mathrm{L} \\
\text { solution and } 6 \text { in. of Pu solid }\left[3 \mathrm{~g} \mathrm{Pu} / \mathrm{cm}^{3} \text { as } \mathrm{PuO}_{2}\right] \text { at } \\
\text { bottom of tanks. Three other tanks contain } 1 \times 10^{-3} \mathrm{~g} \mathrm{Pu} / \mathrm{L} \\
\text { solution. No Pu solution in vacuum filter basin. } \\
\text { Polishing filters empty. No reflection water around } \\
\text { containers or glovebox.) }\end{array}$ & 0.79052 & 0.00118 \\
\hline $\mathrm{bc} 2$ & $\begin{array}{l}\text { bcl plus fill phase separator tank, vacuum trap tank, and } \\
\text { vacuum catch tank contain } 50 \mathrm{~g} \mathrm{Pu} / \mathrm{L} \text { solution. }\end{array}$ & 0.79195 & 0.00111 \\
\hline $\mathrm{bc3}$ & $\begin{array}{l}\text { bc2 plus } 1 \text { in. of } 450 \mathrm{~g} \mathrm{Pu} / \mathrm{L} \text { solution below perforated } \\
\text { plate in vacuum filter basin. }\end{array}$ & 0.79078 & 0.00105 \\
\hline $\mathrm{bc4}$ & $\begin{array}{l}\text { bc3 plus polishing filter half full of } 3 \mathrm{~g} \mathrm{Pu} / \mathrm{cm}^{3} \text { as } \mathrm{PuO}_{2} \\
\text { and } 50 \mathrm{~g} \mathrm{Pu} / \mathrm{L} \text { solution in the rest from no } \mathrm{Pu} \text { in filter. }\end{array}$ & $0 . \overline{79103}$ & 0.00096 \\
\hline bc5 & $\begin{array}{l}\mathrm{bc} 4 \text { plus } 1 \text { in. of water surrounds all Pu containers and no } \\
\text { water surrounds glovebox. }\end{array}$ & 0.92874 & 0.00153 \\
\hline $\mathrm{bc} 6$ & $\begin{array}{l}\text { bc } 4 \text { plus water surrounds glovebox. No water surrounds } \\
\text { Pu containers. }\end{array}$ & 0.81545 & 0.00141 \\
\hline bc7 & $\begin{array}{l}\text { bc } 4 \text { plus } 1 \text { in. of water surrounds all Pu containers and } \\
\text { outside of glovebox has thick water reflector. }\end{array}$ & 0.94480 & 0.00153 \\
\hline $\mathrm{bc} 9$ & $\begin{array}{l}\text { Tanks surrounded } 1 \text { in. water along } 6 \text { in. of length; boats } \\
\text { have } 1 \text { in. of water reflector on all sides. }\end{array}$ & 0.86351 & 0.00094 \\
\hline $\mathrm{bc} 10$ & $\begin{array}{l}\text { Tanks surrounded by } 1 \text { in. of water along } 6 \text { in. of length, } \\
\text { boats have } 1 \text { in. of water reflector on its top only. }\end{array}$ & 0.86261 & 0.00096 \\
\hline bc11 & $\begin{array}{l}\text { bc } 9 \text { plus } 12 \text { in of water around, } 6 \text { in below, } 1 \text { in. on top } \\
\text { of glovebox }\end{array}$ & 0.88774 & 0.00171 \\
\hline $\mathrm{bc} 12$ & $\begin{array}{l}\text { bc } 10 \text { plus } 12 \text { in of water around, } 6 \text { in. below, } 1 \text { in. on top } \\
\text { of glovebox }\end{array}$ & 0.88589 & 0.00171 \\
\hline $\mathrm{bc} 13$ & bcl without hot plate boat & 0.73714 & 0.00100 \\
\hline bc14 & $\begin{array}{l}\text { bc } 13 \text { has } 50 \mathrm{~g} / \mathrm{L} \text { solution in place of } 6 \text { in. solid } \mathrm{Pu} \text { in } \\
\text { tanks. }\end{array}$ & 0.59772 & 0.00091 \\
\hline $\mathrm{bc} 15$ & $\begin{array}{l}\text { bc12 with precipitator tanks filled to } 20 \mathrm{~L} \text {, instead of } \\
12 \mathrm{~L}\end{array}$ & 0.88697 & 0.00142 \\
\hline
\end{tabular}

Cases bc 1 to bc 6 steps from the normal condition (nca) to a more complete model by covering a range of abnormal but anticipated operation conditions. The cases also explore several overly conservative arrangements. These cases are listed to understand the relative reactivity of the different items contributing to the reactivity of the glovebox. Each case adds fissionable mass or reflection. Cases bc 9 to bc 12 add water reflection. Cases bcl3 and bc14 explore some alternate configurations. Case bc15 is defined as the base case. It has all the worst case configurations except that l" water reflection is limited to a 6 " length of the precipitation tanks, which is as much as can realistically be covered by an operator's hands or a damp rag. 
Case bcl adds the first increase in reactivity from the normal operation condition (case nca) to the precipitator tanks. It puts 6 " of $\mathrm{Pu}$ solid $\left(3 \mathrm{~g} \mathrm{Pu} / \mathrm{cm}^{3}\right.$ as $\mathrm{PuO}_{2}$ saturated with water) at the bottom of the tank and leaves $50 \mathrm{~g} \mathrm{Pu} / \mathrm{L}$ solution for the rest of the $12 \mathrm{~L}$ height. Each precipitation tank holds $9.36 \mathrm{~kg}$ of plutonium, $8.91 \mathrm{~kg}$ Pu of solids and $0.85 \mathrm{~kg} \mathrm{Pu}$ in the $9 \mathrm{~L}$ of solution. Case bcl fills the three $20.1 \mathrm{~L}$ precipitation process vessels with $250 \mathrm{~g} \mathrm{Pu} / \mathrm{L}$ of plutonium nitrate and water solution. This puts the most reactive concentration of plutonium nitrate into the precipitation process vessels. Case bc2 adds to case bcl the phase separator tank, vacuum trap tank, and vacuum catch tank, each filled with $250 \mathrm{~g} \mathrm{Pu} / \mathrm{L}$ solution. Similarly, case bc3 adds 1 in. of $450 \mathrm{~g} \mathrm{Pu} / \mathrm{L}$ solution below the perforated plate of the vacuum filter basin to case $b c 2$. Case bc 4 adds to bc 3 the polishing filter half full of $3 \mathrm{~g} \mathrm{Pu} / \mathrm{cm}^{3}$ as $\mathrm{PuO}_{2}$ saturated with water and the other half filled with $250 \mathrm{~g} \mathrm{Pu} / \mathrm{L}$ solution.

Case bc 5 puts 1 in. of water around all fissionable containers from case bc 4 but without water surrounding the glovebox. Case bc 6 reversed the process by surrounding the glovebox with water but no close fitting water surrounds the fissionable material containers. Case bc7, an overly conservative configuration, has 1 in. of water surrounding all the containers including the tanks and has water reflection outside the glovebox also.

Case bc7 shows that having 1 in. of water around the entire precipitation tank exceeds the allowable limit. A more realistic assumption (bc9) would be to surround a tank with a 6 in. length of one inch of water to simulate an operator's hand or a rag. The glovebox does not have sufficient gloveports to get even one pair of hands to each container. After various parametric tests (bc10 to bc14), a base case, bc15, was found that accommodated all the requirements established in Tables 5-2-1 to 5-2-3. 
HNF-6537 REV. 0

APPENDIX H - BASIS DOCUMENT

H-1 
HNF-6537 REV. 0

This page intentionally left blank.

$\mathrm{H}-2$ 


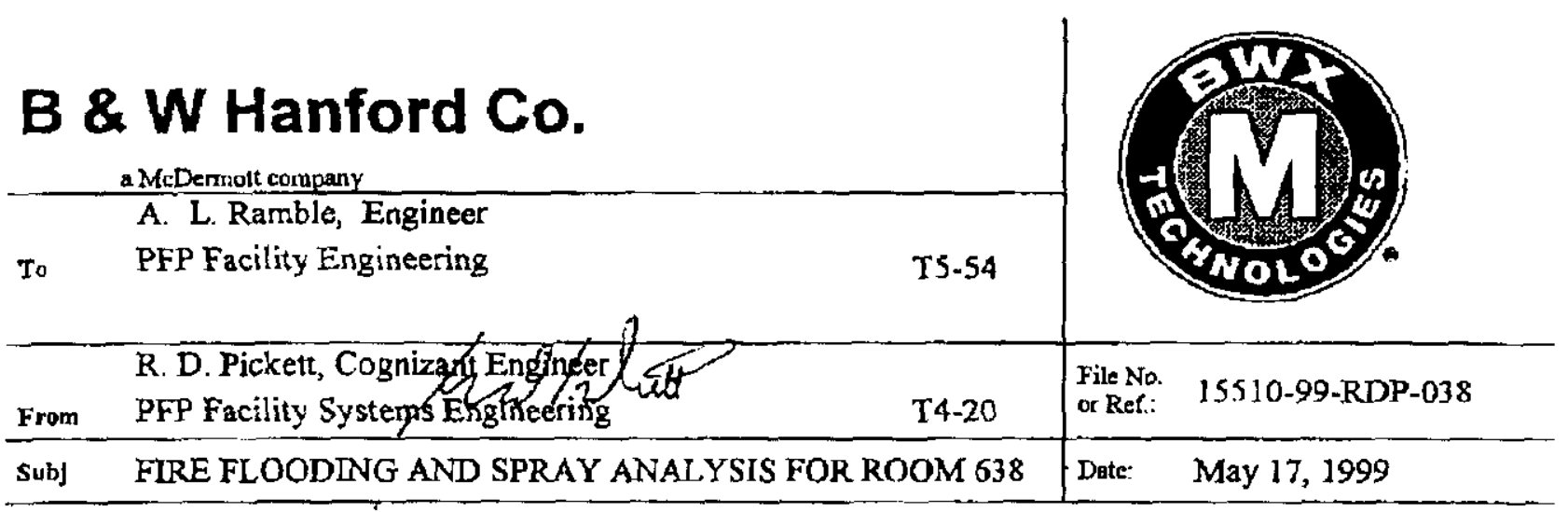

Reference: Telephone Request for Fire Water Flooding and Spray Aralysis, dated May 7, 1999.

\section{ASSUMPTIONS}

- Fire department on scene within 40 minutes (see FSAR section 9.2.2A).

- $120 \mathrm{psi}$ at cach sprinkier head (this is very conservative since line losses and operation of other sprinkler heads would decrease this pressure).

- Fight a fire with two hases for a total of $400 \mathrm{gpm}$ (one hose at $100 \mathrm{gpm}$ and second hose at $300 \mathrm{gpm}$ per information provided by the fire department). Note: these hoses are variable stream types so the pattern and flows are adjustable.

- For flooding, assume all sprinkler heads operate (this is worse than a shear of a $11 / 2^{\text {" water }}$ line).

- 1 second of flow from a sprinkler head or hose will suspend the amount of water to achieve the maximum density.

- Assume 3 sprinkler heads worth of flow into the cage area.

- No leakage out of the room.

- There is $8 \mathrm{lb}$. Water in 1 gallon.

- Exclude floor space and volume of room 639 and 640.

\section{BACKGROUND}

- Area of the room floor $=130 \mathrm{ft2}$.

- 14 sprinkler heads in the room (see CVI 21097)

- Sprinklers have a 1/2" orifice with a $5.62 \mathrm{~K}$-factor.

- There are 7.481 gallons per ft3.

- Occupational Classification is Ordinary Hazard (see CVI 21097)

- Caged area has two sprinkler heads.

- Ceiling height is $9^{\prime} 6^{\prime \prime}$.

- Floor dimensions of caged area 7' $\times 18^{\prime} 3^{\prime \prime}$

- Probability of fire not being noticed and the fire department being delayed 30 minutes is discussed in section 9.2.2A of the FSAR.

- Flooding cannot occur when a fire hose is used since the doors to the room have to be open along the hose route all the way to the outside of the building. There are no hose connections inside $2736-Z B$ or $2736-7$. 
A. L. Ramble, et. al.

15510-99-RDP-038

Page 2

May 17, 1999

\section{CALCULATIONS}

Flow per sprinkler head $=Q=K \sqrt{P}=5.62 * \sqrt{120}=61.56 \mathrm{gpm}$

Sprinkler flow into cage area $=3 * 61.56=185 \mathrm{gpm}$

Sprinkler flow into the whole room $=14 * 61.56=862 \mathrm{gpm}$

Volume of cage area $=7^{\prime} * 18^{\prime} * 9.5^{\prime}=1200 \mathrm{cu}$. ft.

\section{CAGE DENSITY CALCULATIONS}

Cage Density during fire fighting in cage area $=185 \mathrm{gpm}$ from sprinklers $+400 \mathrm{gpm}$ from fire hoses $=585 \mathrm{gpm}$ total flow.

Water released in 1 second of sprinklers and hoses $=585 \mathrm{gpm} *(1 \mathrm{~min} / 60 \mathrm{sec}) * 1 \mathrm{sec}=9.75$ gal.

Water density in cage area $=9.75 \mathrm{gal} / 1200 \mathrm{cu} . \mathrm{ft} .=0.0081225 \mathrm{gal} / \mathrm{cu}: \mathrm{ft}$.

\section{FLOODING CALCULATIONS}

Volume of water release in 40 minutes $=40 \mathrm{~min} * 862 \mathrm{gpm} *(1 \mathrm{cu} . \mathrm{ft} . / 7.481 \mathrm{gal})=4609 \mathrm{cu} . \mathrm{ft}$.

Water level after $40 \mathrm{~min} .=4609 \mathrm{cu} . \mathrm{ft} . / 1340 \mathrm{sq}$. ft. floor area $=3.44 \mathrm{ft}$.

\section{CONCLUSYONS}

After 40 minutes of sprinkler flow, the water level in room 638 will be 3.44 feet. The maximum density of water suspended in the cage area is $0.008-\mathrm{gal} / \mathrm{cu}$. $\mathrm{At}$.

$k \operatorname{lm}$

Distribution

Fluor Daniel Northwest

K. D. Dobbin

B4-44

J. S. Lan

B4-44

J. A. Miller

B4-44

RDP File/LB 


\title{
F-2. Density Memo
}

\section{5 \\ FLUOR DANIEL HANFORD, INC. \\ INTEROFFICECORRESPONDENCE}

\author{
To: \\ E. M. Miller, \\ B4-44 \\ Date: \\ March 9, 2000 \\ From: \\ S. A. Jones \\ T5-12 \\ Telephone: \\ $373-3347$ \\ cc: \\ File No. \\ 1AF00-00-022 \\ Subject: \\ MAGNESIUM HYDROXIDE CALCINED PRODUCT WATER CAPACITY
}

This letter transmits the results of a test performed in the Plutonium Process Support Laboratories (PPSL) to measure the void volume and capacity to hold water of a calcined product resulting from magnesium hydroxide precipitation and calcination of plutonium from nitric acid solution. The information is provided to support criticality safety analyses.

The item tested was a precipitate from magnesium hydroxide process testing that had been filtered, washed with water, and dried in a muffle furnace heated to $1000^{\circ} \mathrm{C}$. A loss-on-ignition (LOI) analysis of this material result was $0.49 \%$ weight loss. It was assumed that the magnesium hydroxide $\left(\mathrm{Mg}(\mathrm{OH})_{2}\right)$ had been converted to magnesium oxide $(\mathrm{MgO})$ in the furnace and that plutonium was present as plutonium dioxide $\left(\mathrm{PuO}_{2}\right)$ in the dried solid. Chemical assay of the dried precipitate was performed with the result that this material contained $31 \%$ plutonium. Converting this to $\mathrm{PuO}_{2}$, there was $35 \% \mathrm{PuO}_{2}$ by weight. It was assumed for calculations that the remaining weight was due to $\mathrm{MgO}$ although other metal impurities from the test solution are included in this material.

The density of dry precipitate was measured by breaking up any large chunks of solid until all solid was a fine powder. This was easily accomplished manually by pressing a spatula against the large pieces. The powder was scooped into a tared graduated cylinder that was filled to the $50-\mathrm{mL}$ line. The weight of the cylinder and powder was measured and the net solids weight was 29.5 grams. The cylinder was then tapped on the floor of the glovebox until not further solids reduction was observed. This final volume was $37 \mathrm{~mL}$. From these values, the bulk density was $0.59 \mathrm{~g} / \mathrm{cc}$ and the tap density was $0.80 \mathrm{~g} / \mathrm{cc}$.

The graduated cylinder was emptied, rinsed with water, 1ared, filled to the $25 \mathrm{~mL}$ mark, and weighed. Solid was added slowly until all free water had been absorbed. This point was determined to be when no free liquid was visible on the surface of the solids. In this test, $23.7 \mathrm{~g}$ was absorbed by $25.7 \mathrm{~mL}$ of water and the final volume of the wet solids was $30 \mathrm{~mL}$. From the tap density of the dried precipitate, $23.7 \mathrm{~g}$ would occupy $30 \mathrm{~mL}$.

Water-saturated calcined product contained $52 \%$ water. Using $65 \mathrm{wt} \% \mathrm{MgO}$ in the solid, it was calculated that $7 \mathrm{~mL} \mathrm{H}_{2} \mathrm{O}$ would be required to convert $\mathrm{MgO}$ to $\mathrm{Mg}(\mathrm{OH})_{2}$. It is uncertain the rate at which this conversion will occur in the calcined product. If $\mathrm{MgO}$ converts to $\mathrm{Mg}(\mathrm{OH})_{2}$, the remaining $19 \mathrm{~mL}$ of water in this test fills the void volume in the precipitate. This represents $63 \%$ of 


\section{FLUOR DANIEL HANFORD, INC.}

\section{NTEROFFICECORRESPONDENCE}

E. M. Miller

Page 2

March 9, 2000

the solid volume. If the conversion does not occur, the void volume is $25 \mathrm{~mL}$ out of $30 \mathrm{~mL}$ or $87 \%$. This does not change the conclusion that the solids contained $52 \%$ water by weight.

It should be noted that these observations are for a single test with a single batch of precipitate. The character of the calcined precipitate appears to be largely governed by the properties of magnesium oxide. In other testing, the highest plutonium concentration observed was $61 \mathrm{wt} \%$. Depending on impurities in the feed solution, the plutonium concentration may be very low.

Raw data and calculation results are listed in the table below for your information. If further explanation of this test is required, please feel free to contact me.

\begin{tabular}{|c|c|}
\hline Precipitate Density Measurements, Dry & \\
\hline Empty Graduated Cylinder Weight, $\mathrm{g}$ & 21.047 \\
\hline Graduated Cylinder Weight with $50 \mathrm{~mL}$ Dry Precipitate & 50.569 \\
\hline Precipitate Weight, 9 & 29.522 \\
\hline Precipitate Bulk Density, g/cc & 0.590 \\
\hline Volume of Precipitate, Tapped Down, cc & 37 \\
\hline Precipitate Tap Density. g/cc & 0.798 \\
\hline \multicolumn{2}{|l|}{ Precipitate Density Measurements, Wet } \\
\hline Empty Graduated Cylinder Weight, $\mathrm{g}$ & 22.061 \\
\hline Graduated Cylinder Weight with $\sim 25 \mathrm{~mL}$ Water, $g$ & 47.741 \\
\hline Graduated Cylinder Weight Water + Dry Solids, 9 & 71.45 \\
\hline Dry Solids Weight Added to Water, 9 & 23.709 \\
\hline Wet Solids Weight, $\mathrm{g}$ & 49.389 \\
\hline Final Volume of Wet Precipitate, cc & 30 \\
\hline Density of Wet Solids, g/cc & 1.65 \\
\hline Nolume of Precipitate, cc (using tap density) & 29.7 \\
\hline \multicolumn{2}{|l|}{ Precipitate Composition } \\
\hline Solids Plutonium Content, \% & 31 \\
\hline Solids $\mathrm{PuO}_{2}$ Content, \% & 35 \\
\hline Solids $\mathrm{MgO}$ Content, $\%$ & 65 \\
\hline Solids MgO Content, moles & 0.38 \\
\hline Water to Hydrate $\mathrm{MgO}, \mathrm{g}$ & 6.9 \\
\hline Free Water, 9 & 18.8 \\
\hline
\end{tabular}

